\title{
(ब) A LUZ ALÉM DA CENA Vestígios do olhar de uma iluminadora
}

\author{
CLÁUdIA DE BEM
}

São Paulo 


\author{
UNIVERSIDADE DE SÃO PAULO \\ ESCOLA DE COMUNICAÇÃO E ARTES \\ PROGRAMA DE PÓS-GRADUAÇÃO EM ARTES CÊNICAS
}

\author{
A LUZ ALÉM DA CENA \\ vestígios do olhar de uma iluminadora \\ Cláudia de Bem
}

Tese apresentada ao Programa de Pós-graduação da Escola de Comunicação e Artes da Universidade de São Paulo para obtenção do título de Doutora em Artes Cênicas

Orientadora: Profa. Dra. Elisabeth Silva Lopes

Área de Concentração: Pedagogia do Teatro Linha de pesquisa: Formação do artista teatral

São Paulo

2020 
[Ficha Catalográfica]

Autorizo a reprodução e divulgação total ou parcial deste trabalho, por qualquer meio convencional ou eletrônico, para fins de estudo e pesquisa, desde que citada a fonte. 
BEN, Cláudia Pinto. A LUZ ALÉM DA CENA: vestígios do olhar de uma iluminadora. Tese (Doutorado) apresentada ao Programa de Pós-graduação da Escola de Comunicação e Artes da Universidade de São Paulo para obtenção do título de Doutora em Artes Cênicas.

Aprovada em:

\section{BANCA EXAMINADORA}

Prof. Dr. Instituição

Julgamento Assinatura

Prof. Dr. Instituição Julgamento Assinatura

Prof. Dr. Instituição Julgamento Assinatura

Prof. Dr. Instituição Julgamento Assinatura 
Dedico esta tese às duas mulheres valentes e muito importantes em minha vida: Vera de Bem (que meu deu à luz), in memoriam e Juliana Ben (a quem dei à luz) 
À Universidade de São Paulo e ao programa de pós-graduação em Artes Cênicas, por acolher esta pesquisa e, em caráter amplo, a todos os professores e funcionários do programa pelo incentivo e qualidade dos serviços prestados e, em especial à Tamara Sciré.

Aos professore(a)s doutores que participaram da Banca de qualificação e àqueles que compõem a Banca Examinadora, por se disporem a trazer suas valiosas contribuições.

Em especial, agradeço a todos os artistas: Carina Donida, Thaís Petzhold, Matheus Kleber, Fernanda Valadares, Ana Eliza Colomar, Bukuritós Aruanda, Kabila Aruanda, Gisele Peixe, Mário Carvalho, Marco Perez e amigos que colaboraram efetivamente com seus corpos, e possibilitaram a realização desta pesquisa artística.

Ao coletivo da Usina da Alegria Planetária, que me recebeu em seu espaço sagrado.

A todos os professores, amigos e colegas de profissão que contribuíram com a minha trajetória. Com carinho, ao mestre e artista da luz Wagner Pinto que enriqueceu meus repertórios de luz.

A minhas mães de Santo: Regina Silveira (mãe de santo) e Selma Bosco (Ekedi) e nossa família, por me cuidarem num outro plano. Motumbá axé.

Aos amigos do coração Cláudia Villar Justiniano, Luciana Tiscoski e Dr. José Belizário pela escuta, apoio e aconselhamento.

À amiga Elidia Novaes e seu olhar de lince ao revisar meus textos com precisão e carinho.

À minha orientadora, professora e artista Dra. Elisabeth Lopes, que além da sua contribuição valiosa, compreensão, amizade e incentivo, me apresentou caminhos criativos, respeitando sempre meu processo.

Por fim, aos protetores, anjos, xamãs, bruxas, Orixás e deuses que, com suas luzes e sombras, seguem comigo sempre. 
Labirinto

Não haverá nunca uma porta. Já estás dentro.

E o alcácer abarca o universo

E não tem anverso nem reverso

Não tem extremo muro nem secreto centro.

Não esperes que o rigor do teu caminho

Que fatalmente se bifurca em outro,

Que fatalmente se bifurca em outro,

Terá fim. É de ferro teu destino

Como o juiz. Não creias na investida

Do touro que é um homem cuja estranha

Forma plural dá horror a essa maranha

De interminável pedra entretecida.

Não virá. Nada esperes. Nem te espera

No negro crepúsculo uma fera

- Jorge Luís Borges / tradução de Augusto de Campos 
Esta tese é, antes de tudo, uma pesquisa sobre arte que se abastece da invenção de conceitos diante da produção artística. Ao colocar-se como pesquisadora do próprio processo artístico, a autora ensaia uma filosofia para a luz procurando dar sentido à sua manifestação com a criação de poéticas que se inter-relacionam. A iluminadora insiste na autonomia da luz como materialidade para a criação, processo artístico que não se limita à função de recurso espetacular para se tornar a obra em si. O convite aos leitores na pesquisa e ensino da arte volta-se para olhar a luz como substância da imagem, questionando-se especialmente sobre a produção perceptiva daquilo que vemos e queremos ver. A escritura deste estudo é feita de imagens vivas, corporificada nas memórias e histórias que são recontadas e redesenhadas pelo prisma da artistapesquisadora da luz. Suas memórias, por vezes, configuram-se em labirintos criativos, e mostram-se em registros visuais e descrições sensíveis dos transcursos. Mediadas pelo olhar subjetivo da autora, as imagens são trabalhadas posteriormente, capturadas pela câmera fotográfica e desenvolvidas criativamente com softwares, ferramentas tecnológicas que ampliam a percepção dos fenômenos luminosos, os quais intervêm na produção estética e revelam-se em transparências e experiências performativas com o fogo. Os elementos naturais e suas possibilidades técnicas e poéticas inspiram a criação e as práticas artísticas da pesquisadora, visibilizando acontecimentos e imprevistos da luz nos corpos que surgem em seu entorno. Não é sempre um trabalho solitário; além do diálogo com as diferentes paisagens, do campo ou da cidade, a pesquisadora recorre à partilha com diversos artistas de distintos campos da arte e formas de vida, e juntos atravessam labirintos, mas não se contentam com saídas; talvez com novos labirintos que estimulem o desconhecido, a magia e a imaginação.

Palavras-chave: luz, olhar, percepção, imagem, iluminadora 
This thesis is, above all, a research on art that draws on the invention of concepts in the face of artistic production. In assuming her position as a researcher of her own artistic process, the author tests a philosophy on light, seeking to give meaning to its manifestation by creating interrelated poetics. This lighting designer insists on the autonomy of light as materiality for creation, an artistic process not limited to the function of a spectacular resource to become the work itself. The invitation to readers in the research and teaching of art turns to face the light as substance of the image, wondering especially about the perceptual production of what we see and want to see. The text in this study is made up of living images, embodied in the memories and stories that are retold and redrawn by the light of this light artist-researcher. Her memories sometimes take the shape of creative labyrinths, and are shown in visual records and sensitive descriptions of the passages. Mediated by the author's subjective observation, the images are developed later, captured by the camera and creatively evolved through softwares, technological tools that expand the perception of luminous phenomena, which intervene in the aesthetic production and reveal themselves in transparencies and performative experiences with fire. The natural elements and their technical and poetic possibilities inspire the researcher's creation and artistic practices, as she visualizes happenings and unforeseen events of light in the bodies seen around her. It is not always a lonely job; in addition to the dialogue with different landscapes, either in the countryside or in the city, the researcher choses to share with different artists from different fields of art and life forms, and together they go through labyrinths, but do not settle for exits; perhaps with new labyrinths that stimulate the unknown, magic and imagination.

Keywords: light, to look, perception, image, light designer 
LISTA DE ILUSTRAÇÕES



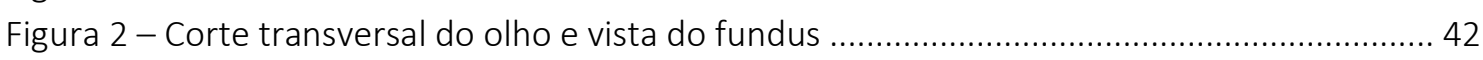

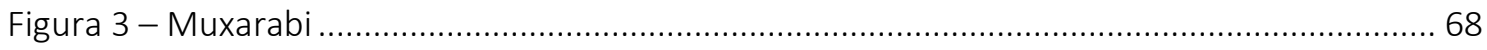

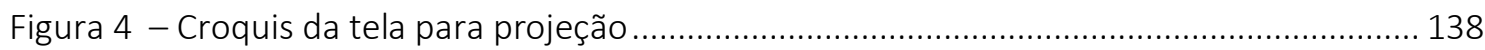

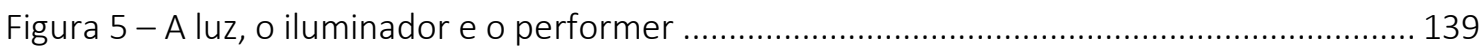

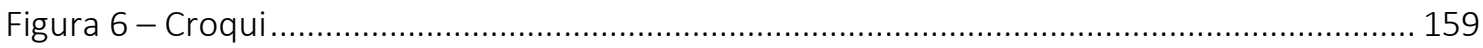

Figura 7 - Paulo de Araújo (desenho a lápis crayon) …....................................................... 218

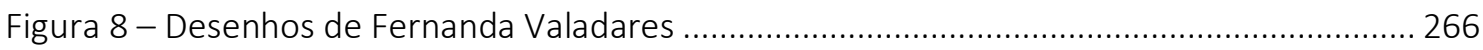



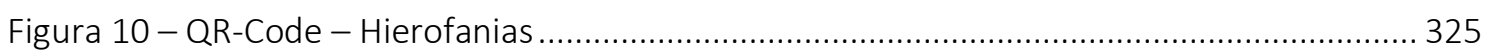

OBS:

A foto da capa é de autoria de Mário Carvalho.

Todas as imagens restantes que constam no texto e não estão listadas são desta autora. 
SUMÁRIO

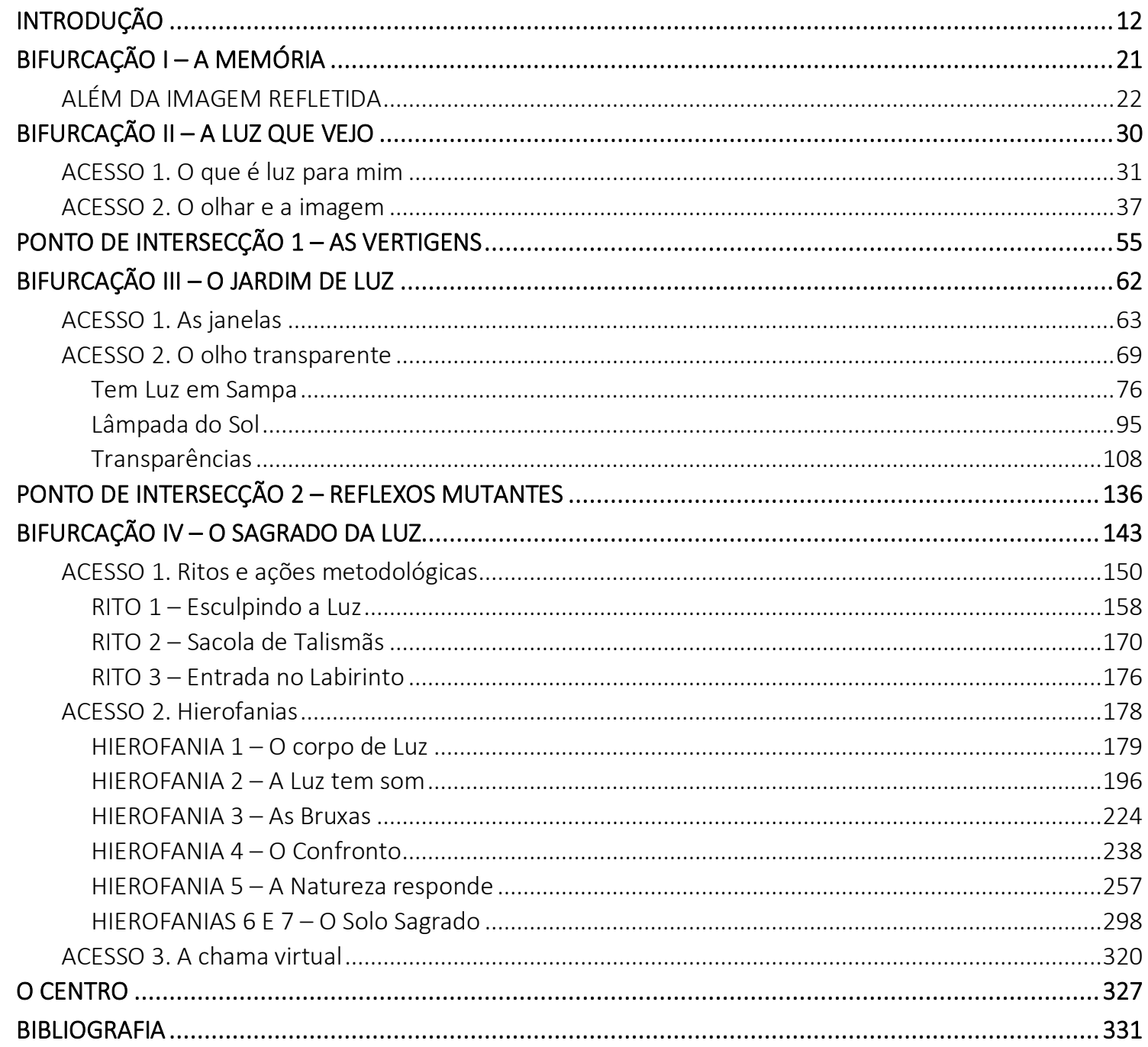




\section{INTRODUÇÃO}

O motivo que me leva a esta escrita é transmitir aquilo que se põe frente aos meus olhos e me coloca diante da luz e das imagens construídas pela percepção, memórias e experiências vividas em práticas artísticas. Creio que muitas vezes não conseguimos decifrar e nem compreender nosso processo de visualidade, nos impondo limites e restrições à compreensão. Visualidade designada ao ato de ver, como aquilo que o olhar contempla num campo estendido, um espaço localizado entre a percepção e o conhecimento sensível. Me interessa espiar a luz e entender como ela se impõe diante das imagens que percebo no mundo e nas minhas criações, sejam elas no cotidiano, na cena, na arquitetura, na fotografia ou nas artes visuais. Apesar da imensidão de aspectos que envolve esta temática, vou pelo mais simples, a própria experiência artística. Espero que, através dela, eu possa trazer contribuições e contaminar o leitor com a paixão pela qual fui envolvida durante esta caminhada.

Na busca de tecer considerações acerca da luz, e ao mesmo tempo me nutrir de sinceridade intelectual, traço uma justificativa contundente para o conteúdo desta escritura. Tenho claro que o que sustenta as exposições às quais me imponho deriva de alto grau de subjetividade e complexidade, inclusive quanto a intenções, motivações, desejos e objetivos. Assim, os limites dizem respeito ao tema - a luz - que considero inesgotável. 
Portanto, o conteúdo desta tese sugere além da contribuição acadêmica um resultado contributivo à pesquisadora de crescimento individual na construção de um trabalho científico que implicou em momentos compensadores de conscientização de ações artísticas e do pensamento criativo. Interessa também a interlocução com artistas, pesquisadores e aqueles que têm interesse em dialogar e refletir sobre práticas experimentais no eixo arte-percepção que promovem a sensibilização do olhar como ação metodológica para a formação em artes.

Do processo de esclarecimento e descobertas sobre a luz que transitam entre subjetividade e objetividade surgiu a necessidade de desconstruir minhas ações artísticas e alguns conceitos pré-concebidos, referências e convenções que muitas vezes agiam como vieses e me acompanhavam na prática artística de iluminadora cênica. O termo desconstruir é usado no sentido dado pelo filósofo francês-magrebino Jacques Derrida, de desfazer, decompor, des-sedimentar estruturas para enxergar outras possibilidades, dar outros significados.

Assim me propus inicialmente a investigar o olhar, este olhar que junta os fragmentos e os desfaz no sentido proposto por Derrida em sua teoria da desconstrução. Vista do campo literário e filosófico, ela consiste em desfazer o texto a partir do modo como foi organizado originalmente para revelar seus outros significados, o que leva a pensar sobre os conceitos de desmonte, reconstrução, reorganização das ações e 
operações teórico-práticas significativas das minhas ações artísticas. Isto requer desaprender e reaprender práticas e reestruturar conceitos antes cristalizados.

Ao refletir sobre o que se deposita entre o meu olhar, o meu modo de operar na arte e a representação que dele emerge como luz e imagem, a primeira proposição está em dissociar a arte da iluminação cênica e a luz, termos que parecem integrados, mas têm diferentes naturezas e ocupam diferentes espaços. A capacidade elevada de criatividade e a possibilidade de desdobramentos artísticos com a luz, além de suas manifestações que até então eu conhecia, impossibilitavam atribuir à luz um conceito ou a descrição de um fenômeno. Qualquer tentativa de sistematizá-la na prática parece diminuir sua presença.

Ao paradoxo envolvido em luz e iluminação, estabeleço diferenças nas sistemáticas da produção de conhecimento, pois apesar de coexistirem, isso requer que sejam compreendidas separadamente. Para existir iluminação é preciso luz, mas a luz prescinde da iluminação. Na relação entre iluminação e luz podemos perceber um jogo de inúmeras possibilidades perceptivas e componentes subjetivos. "Existem duas maneiras profundamente diferentes de conhecer uma coisa, a primeira implica que rodeemos a coisa; a segunda, que entremos nela"1. Eu me dispus a entrar na luz ao experimentar novas práticas de expressá-la, distantes da cena, encontrando outros significados de sua representação e de meu olhar sobre ela. O desfazimento da dualidade

\footnotetext{
${ }^{1}$ BERGSON, 2005, p.21
} 
entre material/imaterial, visível/invisível, sagrado/profano atribuídos à luz colaboram para o distanciamento em pensá-la apenas como iluminação cênica. Nesse caminho, desejei outro lugar para ela, considerando o que estes oximoros erguem na construção teórica de argumentos consistentes sobre a poética da luz, passando pelo diálogo entre autores, por teorias que se indagam sobre o fenômeno, e pelos modos como este se manifesta nos processos das práticas artísticas.

Para estabelecer uma dinâmica própria de reflexão e interpretação das experiências e não objetivar uma resposta, escolho iniciar com a questão: o que é luz para mim como um desafio do percurso, o início da trajetória para articular como processo formativo e operante do pensamento sensível sobre as ações artísticas que realizamos. Diante disso, o que se segue são reflexões, narrativas textuais e imagéticas a partir de práticas experimentais de uma iluminadora desenroladas no campo da performance, estabelecendo um diálogo profundo entre a luz natural, o olhar e a imagem como base estrutural de reconhecimento e elevação do processo perceptivo e do conhecimento sensível da ação artística.

O processo de trabalho compreende uma série de ações e sistemáticas que visam chegar à materialização das experiências envolvendo registros e descrições sensíveis de etapas percorridas e reflexões científicas sobre novas formas de percepção sobre o fenômeno da luz. 
Escolho o termo iluminador(a) como o(a) artista que utiliza a luz como ferramenta criativa e constitutiva da imagem. Essa escolha se justifica pelo entendimento deste ser o mais representativo no amplo espectro de atuação que envolve minha prática artística e as experiências descritas nesta tese.

Considero, aqui, pertinente a performance no sentido atribuído por Schechner ${ }^{2}$ :

O 'Ser' performance é um conceito que se refere a eventos definidos e delimitados, marcados por contexto, convenção, uso e tradição. No entanto, qualquer evento, ação ou comportamento pode ser examinado 'como se fosse' performance.

Tratar o objeto, obra ou produto como performance significa investigar o que a coisa faz, como interage com outros objetos e seres, e como se relaciona com os outros objetos e seres. Dentro deste conceito, a ação da iluminadora, dos performers, da luz e do olhar são vistos como objetos da performance, e serão examinados como tal no texto.

À imagem atribuo todas as formas visíveis e invisíveis construídas pelo olhar da pesquisadora, dos colaboradores e performers nas práticas artísticas materializadas em diferentes linguagens: escritos, relatos, desenhos, fotografias e meio virtual. O olhar é visto sempre com dupla perspectiva entre o objeto e o corpo. Nesta perspectiva, estabeleço algumas camadas subjetivas como membranas presentes nos deslocamentos

\footnotetext{
2 RICHARD SCHECHNER é professor da New York University, diretor de teatro e fundador e editor da revista The Drama Review, publicada pela NYU. In: O PERCEVEJO, ano 11, 2003, n.12, p.25
} 
dos corpos percorridos nas práticas. São elas: olhar, imagem, memória, percepção, visível e invisível; sagrado e profano. As camadas não estão numa organização lógica, são vistas como entrecruzamentos que ajudam a definir com mais precisão as etapas e ações desenroladas no processo artístico.

Precisei ativar um espaço físico para a escrita, uma intenção a forma que se comunicasse com a prática. Visualizei um caminho espiralado com algumas bifurcações. Aos poucos, outros caminhos entrecruzados foram dando ao traçado uma forma mais complexa de aspecto labiríntico. Associei esta imagem aos movimentos e trajetórias que percorremos, encontrando associações místicas e ritualísticas atribuídas aos labirintos por diferentes tradições. Labirintos são espaços que carregam propósitos e desafios para aqueles que os percorrem - utilizados em alguns rituais iniciatórios na busca ao interior de si mesmo, um encontro com o sagrado interior e oculto, um caminho com muitos desvios para alcançar o centro. Desse modo, incorporo esta imagem ao fazer escolhas e tomar direções, aos percursos espiralados dos corpos ao redor do fogo, ao movimento análogo do olhar, por expressões textuais geradas das ações e pelas bifurcações presentes ao acessar diferentes camadas subjetivas. O Labirinto de luz é uma representação imagética e metafórica da escritura que se estrutura em bifurcações como percursos, não desvios, e pontos de intersecção nos entrecruzamentos entre uma bifurcação e outra.

Bifurcação I é o acesso à memória como início de tudo; a redefinição dos valores atribuídos pelos repertórios da memória como constituinte do processo perceptivo e do 
conhecimento sensível. Bifurcação II tem dois acessos: a busca da pesquisadora por declarar a intenção da pesquisa em ressignificados para a luz, por reconhecer a percepção como primeiro gesto de investigação em suas ações artísticas; estabelecer alguns pontos de conexão com conhecimentos científicos e pensamentos filosóficos sobre o olhar e o sensível da imagem para articular com as ações artísticas descritas. Bifurcação III consiste nas experiências estéticas e artísticas da pesquisadora, realizadas em exílio através de duas janelas num apartamento em São Paulo. Descritas na forma de ensaios, vão traçando relações entre o processo de composição das imagens e seus estados subjetivos, alinhavando à experiência estética o caminho percorrido pela percepção, a luz natural e o olhar. Neste convívio reflete sobre a luz e o lugar onde vivem as imagens. Bifurcação IV. Descrição dos percursos imagéticos de performers colaboradores e da pesquisadora, realizados ao redor do fogo. O fogo se impõe como representação da manifestação sagrada da luz. Na intenção de examinar a possibilidade de os corpos gerarem um novo comportamento e a ação nesta relação luz-símbolo, artenatureza, sagrado-profano, foram realizadas sete experiências com diferentes performers num espaço receptivo construído por ações metodológicas que propiciassem um campo energético de atuação, que são descritas ao longo do texto em forma ensaística. Esses relatos assumem a forma de poemas, desenhos, sons, fotografias e movimentos surgidos como linguagens espontâneas em resposta à experimentação. 
Entre as bifurcações, os pontos de intersecção são acontecimentos e inquietações durante o processo, que identificam a intenção da pesquisadora de trazer recortes e fragmentos, como costuras entre uma ação e outra. Por fim, um possível Centro tenta reunir e organizar as reflexões, ressignificados e apontamentos que apontem perspectivas e estratégias de pesquisas artísticas centradas no fenômeno luz-percepção.

O entendimento da construção de uma poética é resultado do entrelaçamento do pensamento e a experiência. Estes laços constituem aquilo que precede a análise, o processo de criação, e, nesse sentido que vejo o pensamento como uma prática teórica criativa, um laboratório onde experimentamos diversos saberes que tomamos emprestados e estruturamos novos saberes. Destes encontros com os autores, extraio teorias que contextualizam minha ação e meu pensar estabelecendo uma identidade com elas e a minha forma de perceber o mundo e agir nele. Assumo uma postura de diálogo com os autores que, mesmo parecendo um pouco romantizada e próxima, tornou a escritura mais autêntica e orgânica. Vejo os filósofos como poetas, e algumas vezes utilizo suas palavras como poesias do pensamento que desenham meu texto, exatamente assim, ilustrações da escrita. Penso que a filosofia é alimento para a poesia que habita em mim e ressoa na minha arte. Assim, com muito apetite, tomo emprestados alguns pensamentos poéticos e conceitos de vários autores e artistas que compareceram e puseram um banquete de subjetividades em minha mesa. Nela compartilhamos alimento e diálogos que vislumbram novos horizontes e conhecimentos. Os rastros e vestígios do artista são os 
registros e o próprio processo; e é a partir destes testemunhos que foi possível organizar uma teorização, uma verdade sobre estas fraturas do olhar e do pensamento.

O texto não é linear, e nem poderia, pois, seu corpo é feito de muitas camadas e texturas que se intercomunicam espacialmente por estas bifurcações e cruzamentos. A trajetória não é reta, é sinuosa como labirinto. Diante do que vemos e como vemos não existe listagem de nada. Não há bordas... 
BIFURCAÇÃO I - A MEMÓRIA

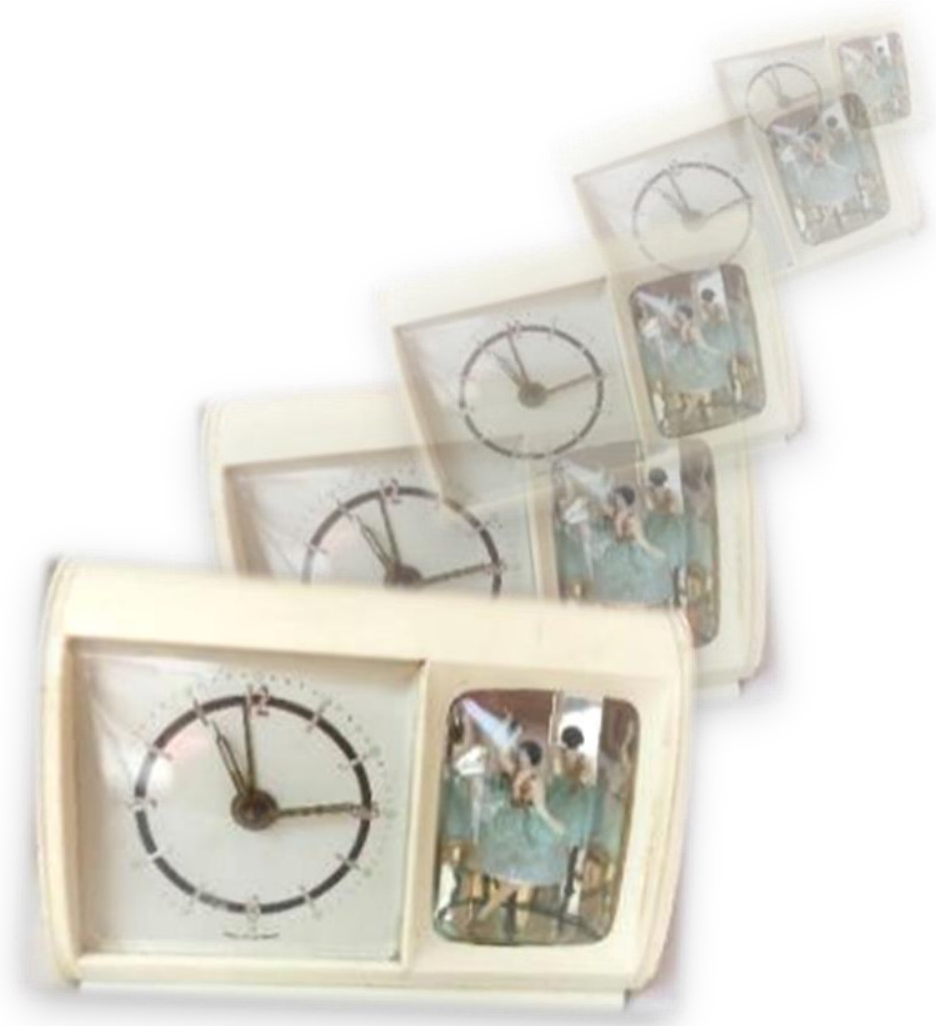

Quando o imperador fitou o espelho, o seu rosto tornou-se uma mancha vermelha de sangue, e depois uma caveira donde escorria mucosidade. O Imperador, horrorizado, desviou o rosto. "Majestade", disse Shenkua. "não desvieis vosso rosto. Só vistes o princípio e o fim da vossa vida. Continuai a olhar para o espelho $e$ vereis tudo o que existe e poderá existir. E quando tiverdes alcançado o máximo enlevo, o próprio espelho mostrar-vosá até mesmo coisas que não podem existir...

- Chin Nung 
Tudo começa num lugar discreto, íntimo e interno. Para mim, numa imagem refletida. Nos primeiros anos de minha infância, no sul do Brasil, vivíamos num apartamento amplo onde havia uma sala de jantar em desnível com a sala de estar. Nessa sala havia uma cristaleira, talvez a única imagem que tenho presente do mobiliário da casa. Nela me vejo, ainda muito pequena, de fraldas, cabelos curtos e um vestido azulado, imóvel a observar a imagem refletida. Creio ter sido a primeira vez em que me vi. Lembro apenas dessa imagem congelada e posso supor que algo ali me surpreendeu, e hoje penso no tamanho do impacto pelo reconhecimento de mim mesma entre os cortes de cristais daquele móvel. A memória da própria imagem, de habitar um outro lugar ao mesmo tempo faz considerar outras possíveis realidades e camadas onde a visão transcende para além da imagem refletida.

Segundo Lacan, entre os seis e oito meses de idade, a criança se defronta com a própria imagem. Numa primeira fase, confunde a imagem com a realidade, depois percebe tratar-se de uma imagem, então compreende que a imagem refletida é sua. Nesse estado de júbilo, a criança reconstrói os fragmentos ainda não unificados do próprio corpo. "[...] A experiência do especular surge do imaginário [...] No momento em que delineia a 'virada' do eu especular para o eu social, o espelho é a 'encruzilhada 
estrutural' ou, como dizíamos, é um fenômeno-limiar que demarca as fronteiras entre o imaginário e o simbólico" ${ }^{3}$. Sobre estas conclusões de Lacan acerca da experiência do espelho num momento específico, único, irrepetível, da ontogênese do indivíduo ao escrever sobre o mundo complexo do espelhos, Eco acrescenta o fato de que, em fases superiores do desenvolvimento da vida simbólica, o espelho pode ser usado para conceder outro significado à experiência.

Nas metáforas sobre espelhos, encontramos mistérios e realidades ocultas, demonstrando que a experiência especular e a percepção caminham juntas.

Como exemplo, proponho fragmentos do conto "O Espelho" de Guimarães Rosa, em que o narrador relata a decisão de visitar o próprio eu a partir de um susto com sua imagem:

[...] Desde aí, comecei a procurar-me - ao eu por detrás de mim - à tona dos espelhos, em sua lista, funda lâmina, em seu lume frio. Isso, que se saiba, antes ninguém tentara. Quem se olha em espelho, o faz partindo de preconceito efetivo, de um mais ou menos falaz pressuposto: ninguém se acha na verdade feio: quanto muito, em certos momentos, desgostamo-nos por provisoriamente discrepantes de um ideal estético já aceito. Sou claro? O que se busca, então, é verificar, acertar, trabalhar um modelo subjetivo, preexistente; enfim, ampliar o ilusório, mediante sucessivas novas capas de ilusão [...] levei meses. Sim,

\footnotetext{
${ }^{3}$ LACAN apud ECO, 1985, p.12
} 
instrutivos. Operava com toda a sorte de astúcias: o rapidíssimo relance, os golpes de esguelha, a longa obliquidade apurada, as contra surpresas, a finta de pálpebras, a tocaia com a luz de repente acesa, os ângulos variados incessantemente. Sobretudo, uma inembotável paciência. Mirava-me, também, em marcados momentos - de ira, medo, orgulho abatido ou dilatado, extrema alegria ou tristeza. Sobre abriram-se enigmas. Se, por exemplo, em estado de ódio, o senhor enfrenta objetivamente sua imagem, o ódio reflui e recrudesce, em tremendas multiplicações: e o senhor vê, então, que, de fato, só se odeia é a si mesmo. Olhos contra olhos. Soube-o: os olhos da gente não têm fim. Só eles paravam imutáveis, no centro do segredo. [... $]^{4}$.

Rosa nos aproxima do tema da imagem que envolve paradoxos entre o real e o imaginário, o visível e o invisível, através de um personagem-narrador que vai traçando um diálogo com a própria imagem, uma experiência fenomenológica como experimentação na busca de si mesmo. Interessante que este olhar para si se refere a aparência física, uma experiência fenomenológica no sentido de enxergar as expressões do olhar em diferentes momentos emocionais e deste enfrentamento urge o dar-se conta de si. Creio que eu, no

\footnotetext{
${ }^{4}$ ROSA, 1972, p.72
} 
insight da cristaleira, vivi uma experiência de visibilidade da imagem, um reconhecimento físico, e por guardar na memória, deve ter sido relevante naquele instante.

A memória é um tempo que retemos para que não desapareça. É a documentação de histórias que se foram e não voltam, mas comprovam nossa existência e dizem muito sobre nós. Quando a visitamos, encontramos sentimentos e experiências daquilo que fomos e do que nos tornamos.

É na infância que experimentamos estes estados puros de contemplação onde repousam as primeiras impressões do mundo sensível e percepções do mundo que guardamos num lugar reservado, são valiosos segredos e histórias imagéticas que nos inspiram, abastecem e se refletem nos processos artísticos, quando resgatados.

Em busca deste tempo passado, acredito que da memória da minha imagem refletida assimilei a noção de presença, de materialidade física no espaço, de estar no mundo, o reconhecimento da existência através da imagem como visibilidade ou aparência, um acesso ao meu ser material. A imagem especular traz uma verdade em que confiamos. Numa dessas fissuras da assimilação, aproximo-me de memórias e imaginação mais remotas que colaboram para o resgate da minha própria imagem, a qual constitui, subjetivamente, o modo como herdei e me conecto física e espiritualmente com meus ancestrais, e trazem vestígios de como percebo e sinto o mundo, e de como constituo minha estética. Desta forma, a experiência contemplativa da minha imagem especular me fez acessar outros conhecimentos do meu mundo privado como uma informação 
subliminar significativa que, antes adormecida na memória, por alguma razão revive agora, neste momento de reflexão sobre meus dispositivos de criação. São peças de um quebracabeça que remontam a minha, mas também, a nossa existência coletiva e que se integram através de uma dinâmica própria e seguem buscando infinitamente outras memórias.

Segundo o relato da minha mãe, na ocasião do meu nascimento, meu pai havia ganho a rifa de um relógio de corda de porcelana na forma retangular (foto da capa). Dentro dele havia um prisma de vidro onde morava uma bailarina. A estrutura do relógio era similar a uma caixinha de música. Ao despertar, acionava uma melodia suave que acordava a bailarina, e ela dançava e girava ao redor do prisma. Com esse movimento, a imagem da bailarina refletida no prisma era triplicada. Não sei o porquê da ligação entre estas duas lembranças; sei apenas que a bailarina refletida no prisma era semelhante à minha imagem na cristaleira. E, naquela memória, eu era a bailarina do relógio. Meu pai veio a falecer um ano depois do meu nascimento, e este objeto vivo ainda me acompanha e repousa no meu íntimo, ligado simbolicamente à sua presença.

Neste fluxo de tempo interno e único, mantido por um significado especial afetivo e de conhecimento em conexão com o meu 'eu' amadurecido, até então oculto, restauro alguns sentimentos e entusiasmos, como meu fascínio pelos fenômenos óticos e experiências ilusionistas desde a primeira infância - o deslumbramento nas brincadeiras de focar e desfocar o olhar para enxergar um mundo distorcido, de transformar as excitantes e curiosas nuvens que deixam de ser uma simples massa de ar para tornarem-se seres de 
diferentes formas; as experiências de saturação ao olhar para o sol - a formação do arcoíris com a manipulação de um espelho num raio de luz e as compensações de cores que surgiam na minha retina; os vagalumes que surgiam no anoitecer no campo que imaginava ser os olhos luminosos de duendes; o olhar para as estrelas como enfeites de luz no céu; as diferentes trajetórias da luz pela poeira que atravessava as janelas anunciando algo; a beleza dos cristais e os reflexos brilhantes nos riachos; as memórias de luz que resgato daquelas noites de tempestade, quando a luz elétrica sumia e saíamos em busca das velas, em busca da luz. A chama modificava nosso espaço, novas formas surgiam com as sombras e um outro mundo surgia, de seres imaginários. A magia está em todo lugar - é destas experiências e lembranças em que hoje compreendo que residem os significados de minhas construções imagéticas entre o olhar e o não-vendo, na dispersão da visão que nos conduz a outras imagens e de que forma isto está associado aos meus processos criativos com a luz. São as certezas que vêm das percepções ingênuas que às vezes abandonamos e mais tarde tentamos retomar. São os espaçamentos entre a percepção, a memória e o tempo que muitas vezes nos perdemos a ignorar.

Além da imagem refletida está a memória que, muito mais que lembranças, guarda parte de nossas experiências e forma repertórios do nosso conhecimento sensível. A memória resgata vestígios de quem somos e de onde viemos, dando sentido ao passado, àquilo que está invisível, distante, mas revela a relação entre o tempo e nossa existência. 
Neste acervo de memórias revividas e memórias que constituem sentidos paralelos aos dos 'comportamentos restaurados' ${ }^{5}$, conceito que Schechner usa para situar a representação na noção ampla de performance, está o 'repertório' 6 vivo que, na sua fatura, consegue emendar os nossos retalhos, fazendo-nos perceber os resquícios que ainda permanecem em nós. Redescubro o quanto a inquietude do meu olhar de criança ainda é presente na sensação de recriar outra possível realidade e, agora, de forma sistemática num estado mais puro e genuíno ao qual sou conduzida pelas práticas artísticas. Estes lapsos de memória que retenho têm me levado a associações com a pesquisa artística e à arte do olhar através da cosmogonia da luz, onde resgato um onirismo que parecia perdido, mas ainda permanece vivo nas minhas criações.

A memória é um depósito (repositório) de repertórios que ocupa camadas diferentes do nosso cérebro e, apesar de eu não me deter especificamente neles, um deles me acompanha nestas bifurcações que me dispus a percorrer - o teatro, esta escola de experimentação e descobertas sobre o ser e o fazer artístico onde residem meus entendimentos sobre espaço, luz, corpo e a arte como presença do meu corpo atuante. 0

${ }^{5}$ Comportamento restaurado: ações físicas, verbais ou virtuais que não são iniciantes; são preparadas ou ensaiadas. Uma pessoa pode não ter consciência de que está performando uma sequência de comportamento restaurado. (SCHECHNER, 2006)

${ }^{6}$ Segundo Diana Taylor, Repertório é o termo que define as performances do corpo, do não-registro, da efemeridade do dito e performado, enquanto Arquivo consiste naquilo que é valorizado por ser escrito e lido, o que pode implicar no distanciamento entre pesquisador e objeto de análise ((TAYLOR, 2013) 
teatro me possibilitou livres e múltiplos acessos a experiências estéticas e humanas, alimentando meu conhecimento sensível. Hoje, me coloca neste lugar de amadurecimento e reflexão. Neste repertório estão pensamentos, ensinamentos, histórias e práticas de atores, diretores, produtores, cenógrafos, figurinistas, técnicos, iluminadores e dramaturgos, alguns com os quais convivi e outros que deixam vestígios através de suas obras e compõem o acervo de imagens que ajudei a construir. Ao entrar nestas camadas subjetivas que vão além da imagem refletida, na busca de outras possibilidades artísticas de agir, encontro na memória pontos de interseç̧ão com este espaço coletivo e sensível que é o teatro como parte de um lugar de onde venho e do que sou.

Ao encontrar minha forma no espelho, sigo no sentido de ela tornar-se uma imagem capaz de viver além de mim, na superfície de outras coisas, da minha arte. 


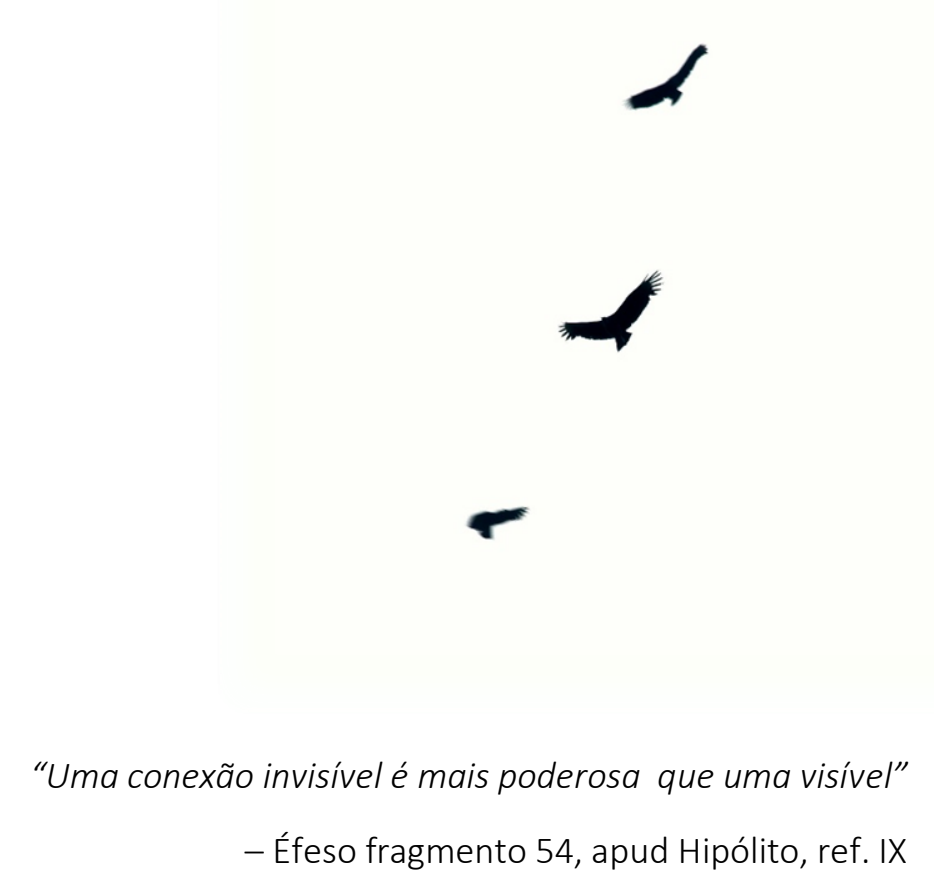


Tenho encontrado conceituações sobre a luz em diferentes áreas de conhecimento: física quântica e ótica, fisiologia ocular, psicologia, bem como alusões na literatura e nas artes, mas desconheço um conceito que imprima a abrangência do tema e me pergunto se é possível encontrar.

O estudo da luz abrange muitas áreas do conhecimento além da experimentação que considero essenciais: a física ótica, a fisiologia da visão, o estudo da percepção e da imagem. A física se preocupa em explicar e comprovar os fenômenos através da experimentação, a fisiologia descreve o processo biológico e químico da visão, a psicologia e a neurociência tentam decifrar o funcionamento do nosso cérebro para entender as sensações e a percepção multissensorial. Já a filosofia da mente nos faz refletir sobre nossa existência através da percepção.

Quando a luz incide na matéria, algo retorna aos nossos olhos. A este fenômeno físico chamamos de reflexão. Então, podemos dizer que a reflexão é um desdobramento de algo que é revelado através da luz, e consequentemente se configura numa imagem que criamos ao observar o fenômeno. Mas o que realmente vemos e interpretamos da imagem refletida? 
Se nos deslocarmos para o pensamento, diremos que refletir é retomar o próprio pensamento, voltar-se para si, enxergar de outra forma a própria imagem refletida, seja de si ou das coisas.

Portanto, aquilo que vemos e identificamos num primeiro momento ao observarmos um objeto é a porção refletida pela incidência de luz. A teoria quântica se preocupou em explicar esse fenômeno ao analisar as partículas de luz, fótons, elétrons e o comportamento da luz na matéria. Da teoria corpuscular formulada por Newton (séc. XVII), seguida da teoria ondulatória de Maxwell (séc. XIX), chegou-se à palavra fóton - as partículas minúsculas que avistamos naquele feixe de luz que penetra pela janela num cômodo empoeirado, dando origem à teoria quântica da luz, que hoje abarca, no estudo da luz, um extenso espectro que envolve as radiações infravermelhas, raios $X$, raios gama e ultravioleta. Por mais que a física traga explicações concretas, existem lacunas ainda indecifráveis em seu comportamento na interação com a matéria. Estes conhecimentos auxiliam na compreensão do caráter da luz na eletrodinâmica quântica, mas se considerarmos que existe interatividade entre a luz e a matéria, precisamos compreender como a natureza se comporta e, na verdade, não existem muitas teorias que expliquem isso.

Sobre a luz, o que me interessa está além de sua assertividade, porque ela conduz o meu corpo e, em especial, o meu olhar sobre, para e com o mundo. Assim, a luz configura um campo de visão de mundo real e abstrato onde se situam minhas ações de interação cognitiva e artística. 
Como falar de luz sem falar de imagem, se uma é inerente à outra? É através da luz que a imagem se revela. Tudo é imagem em construção. O mundo é feito de imagens impregnadas de luz, e nós as construímos diante do que interpretamos e escolhemos ver. A imagem é como o vento, surge num lapso do tempo com diferentes velocidades e intensidades, depois se esvai; algumas se acalmam e silenciam em nossos arquivos secretos. Impossível congelar as imagens, pois a cada momento tudo se move e se transforma.

O imaginário na imagem que criamos parece se constituir de uma organização perfeita que envolve inúmeros processamentos neurais em diferentes partes do corpo. As imagens são recortes do olhar, fragmentos da percepção, a poesia dos olhos que nos conduz a representações imagéticas daquilo que vemos. A incidência da luz desnuda, esconde e revela as formas e os espaços.

Inspirada no conceito da filósofa brasileira Márcia Tiburi, em que "filosofia é a invenção de conceitos que fazem pensar" ${ }^{\prime 7}$, estabeleço como ponto de partida um inventar a luz de modo a encontrar uma filosofia para ela. Não como um tratado, muito menos uma teoria científica; em contraste, são considerações interiorizadas da atividade de pesquisa que relatam o prolongado percurso de uma iluminadora na busca de um discurso para a luz na relação arte fenomenológica-percepção, pensando-a como ideia e substância da própria imagem.

\footnotetext{
${ }^{7}$ TIBURI, 2011, p.53
} 
O sentido de ideia me vem naquilo que Schopenhauer define como objetividade da vontade. A Vontade é o plano de imanência de sua teoria, a origem de todas as coisas. Ele define a vontade como a próxima essência da subjetividade, a próxima essência do "eu". Para aquele filósofo, o mundo era um lugar escuro, de dor; foi rotulado como pessimista, mas acreditava na arte como uma possibilidade de transcendência, um acesso $\grave{a}$ vontade e uma maneira de mitigar o sofrimento. Defendia que o homem não é como um ser unificado e racional, e sim um ser passional, fragmentado, e que a experiência estética é uma maneira de o sentimento vencer a razão. Para ele, o homem é paradoxal, debatendo-se entre o desejo e a vontade num mundo repleto de representações criadas por nós mesmos, e a essência do mundo resulta da vontade de viver de cada um.

Apesar de parecer desconexo e não completamente integrado a nosso tema, com meu aprofundamento em questões trazidas por Schopenhauer, como o racional e o intuitivo num contexto cosmológico e metafísico, esses foram elementos de contato que elevaram expressivamente um pensamento de luz. Na fissura de seus escritos, encontrei para a pesquisa algo substancial em termos de definição, quando ele estabelece conceito e ideia. Para o filósofo, o conceito é abstrato, discursivo, inteiramente indeterminado no interior de sua esfera, definido somente em seus limites, acessível e apreensível por qualquer um, apenas dotado de razão, comunicável através de palavras, sem ulterior mediação, completamente esgotável em sua definição. A ideia, ao contrário, é totalmente intuitiva e determinada ao sujeito puro. A ideia é a unidade decomposta na multiplicidade, 
em virtude da forma espacial e temporal de nossa apreensão intuitiva. Este contato com Schopenhauer traz subsídios para um primeiro questionamento sobre desassociar a arte da iluminação cênica e a luz, que apesar de estarem integradas, residem em diferentes espaços. À luz atribuir o sentido, acepção, subjetividade, uma filosofia; e à iluminação um conceito, a objetividade, a forma de expressar e representar a luz, o ato consistente de materializar a imagem, a arte de manipular e construir imagens com a luz. Alimentando este argumento, encontro asas para ousar, dando à luz o sentido de uma ideia como ato de desconstrução, e repensá-la como substância estética, poética e filosófica do olhar. Enquanto isso, o olhar é visto como a própria condição de existir e perceber o mundo.

Na perspectiva da luz como composição material da imagem, um complemento desta, suponho que ela defina a orientação da imagem. Cada detalhe de um objeto ou ação pode se transformar nesta perspectiva dupla do olhar, onde o ver significa se colocar no espaço e assumir a posição de receptor e observador.

Da luz posso afirmar pouco e sentir muito: a revelação de algo, a alquimia que se dá na fusão com a matéria, o subliminar da imagem, o invisível impregnado na forma. Se eu pudesse conceituar a luz do mesmo modo que a percebo, o faria com palavras soltas: imagem, poesia, fraturas, recortes do olhar, alquimia, sentimentos, magia, doses de beleza e encantamento, fábulas, símbolos, energia, matéria, natureza.

Penso que a percepção é um primeiro movimento de contato com o mundo, uma codificação daquilo que vemos e sentimos através da experiência individual de estar nele. 
As formas como absorvemos suas representações e interagimos nele é tema intrigante para muitos filósofos e para a ciência desde muito tempo. Nas artes, nos apropriamos destas reflexões para estruturar a concepção de uma organização perceptiva dos processos, pensando em apreender e não justificar, pois arte é percepção. Nesta comunicação entre o visível e o invisível que envolve o ato perceptivo, o propósito é reconstituirmos um outro mundo possível para nós ao nos conectarmos com a luz.

A percepção, de fato, é instigante, é um acesso a nós mesmos e traz muitas perguntas quando assumo o ato de criar como reflexo daquilo que percebo.

O que vejo e como vejo?

O que vejo é o que desejo ver?

Eu confio naquilo que vejo a ponto de interagir com minha experiência?

Estas indagações me acompanham como provocações e desafios ao processo perceptivo. Acredito que possamos ver mais se assim desejarmos. Ver torna-se a condição de possibilidade do olhar, e perceber envolve novos hábitos do olhar. Através da arte surge a necessidade de compreender a realidade e renovar nossas relações com a natureza das coisas, ressignificando nosso olhar sobre elas.

Neste contexto, as práticas artísticas que realizamos são testemunhos de um percurso de reconhecimento da percepção, sentidos e memória como mensageiros do conhecimento sensível e da ação criativa. Desta interatividade subjetiva é que investigo e reflito o lugar onde nascem as imagens das poéticas. 
Olhar é não pensar

O meu olhar é nítido como um girassol.

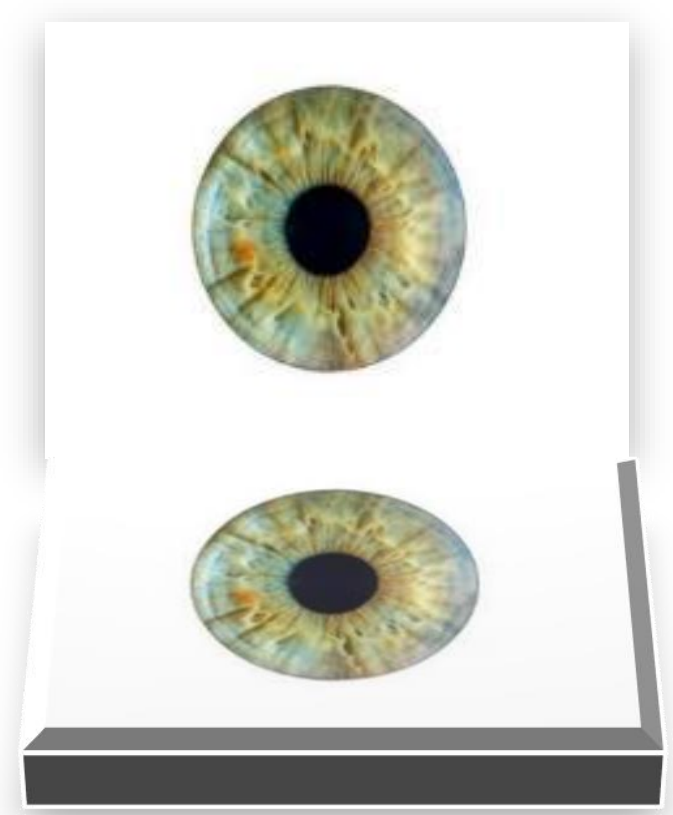

Tenho o costume de andar pelas estradas

Olhando para a direita e para a esquerda,

E de vez em quando olhando para trás...

E o que vejo a cada momento

É aquilo que nunca antes eu tinha visto, E eu sei dar por isso muito bem... Sei ter o pasmo essencial

Que tem uma criança se, ao nascer, Reparasse que nascera deveras... Sinto-me nascido a cada momento Para a eterna novidade do Mundo... Creio no Mundo como num malmequer, Porque o vejo. Mas não penso nele Porque pensar é não compreender... O Mundo não se fez para pensarmos nele (Pensar é estar doente dos olhos) Mas para olharmos para ele e estarmos de acordo... Eu não tenho filosofia: tenho sentidos... 
Se falo na Natureza não é porque saiba o que ela é,

Mas porque a amo, e amo-a por isso,

Porque quem ama nunca sabe o que ama Nem sabe porque ama, nem o que é amar...

Amar é a eterna inocência, E a única inocência é não pensar... - Alberto Caeiro ${ }^{8}$

Ao revisitar o poema de Fernando Pessoa, observo o poder imagético do devir do poeta quando assume o olhar como uma experiência fenomenológica plena na proporção do puro sentimento envolvido nesta ação. Um movimento do sentir destituído de razão. O que o poeta impõe ao olhar é algo que transcende a visão e diz respeito ao que Schopenhauer afirma sobre a ideia como objetividade da vontade, sendo essa a essência da subjetividade. O ato de amar, tema do poema, é a pura contemplação e percepção daquilo que sentimos ao perceber o mundo. Ao comparar seus olhos ao girassol, se refere ao movimento de se colocar no mundo num estado de inocência, como quando nascemos, para tornar visível aquilo que se põe diante de nós e em torno de nós. Para o poeta, ver é sentir. Eis o paradoxo que se manifesta entre o ver e o olhar, e que nos proporciona ampliar a modalidade do visível no processo perceptivo. Dessa forma organizei algumas camadas subjetivas que se intercomunicam no Labirinto de luz e suas

\footnotetext{
${ }^{8}$ O guardador de rebanhos. In: PESSOA, 1996, p. 89
} 
bifurcações nas criações das poéticas, para estabelecer entrecruzamentos dos saberes e as ações artísticas.

A figura 1 apresenta um corte transversal na esfera do olho seccionada em sete camadas, cujo exame considero fundamental por traduzir as subjetividades transcritas nas práticas. Serve ao leitor como representação visual da construção do pensamento da pesquisadora pois, na realidade, elas interagem com os deslocamentos dos nossos corpos e nos circundam o tempo inteiro.

Pouco importa ordená-las, isto seria reduzir suas relações. O que vale é assumir as camadas como movimentos intersubjetivos próprios do caráter fenomenológico envolvido.

$\mathrm{O}$ ato de ver, inicialmente, se relaciona com apenas um padrão ótico, ou seja, nossa atenção direcionada a algo. Pensemos, então, o olho como esfera tridimensional, sendo parte desta esfera externa, uma fatia com abertura de aproximadamente 140 graus vinculada à recepção, ou seja, ao contato com o mundo exterior. A imagem nasce de uma relação entre o olho e a luz, uma experiência de observação que nos chega através de um feixe de fótons e penetra no centro da esfera. Na parte exteriorizada do olho estão os componentes que reagem inicialmente à luz: a córnea, a esclerótica, o cristalino, a íris e a pupila (fig.2). Agem como receptores e protetores dessa radiação. Nesta parte do olho filtramos a porção de luz que compõe a imagem detectada antes de chegar ao interior da esfera, tendo cada um suas funções no processo. 
Figura 1 - Esfera do olho seccionada

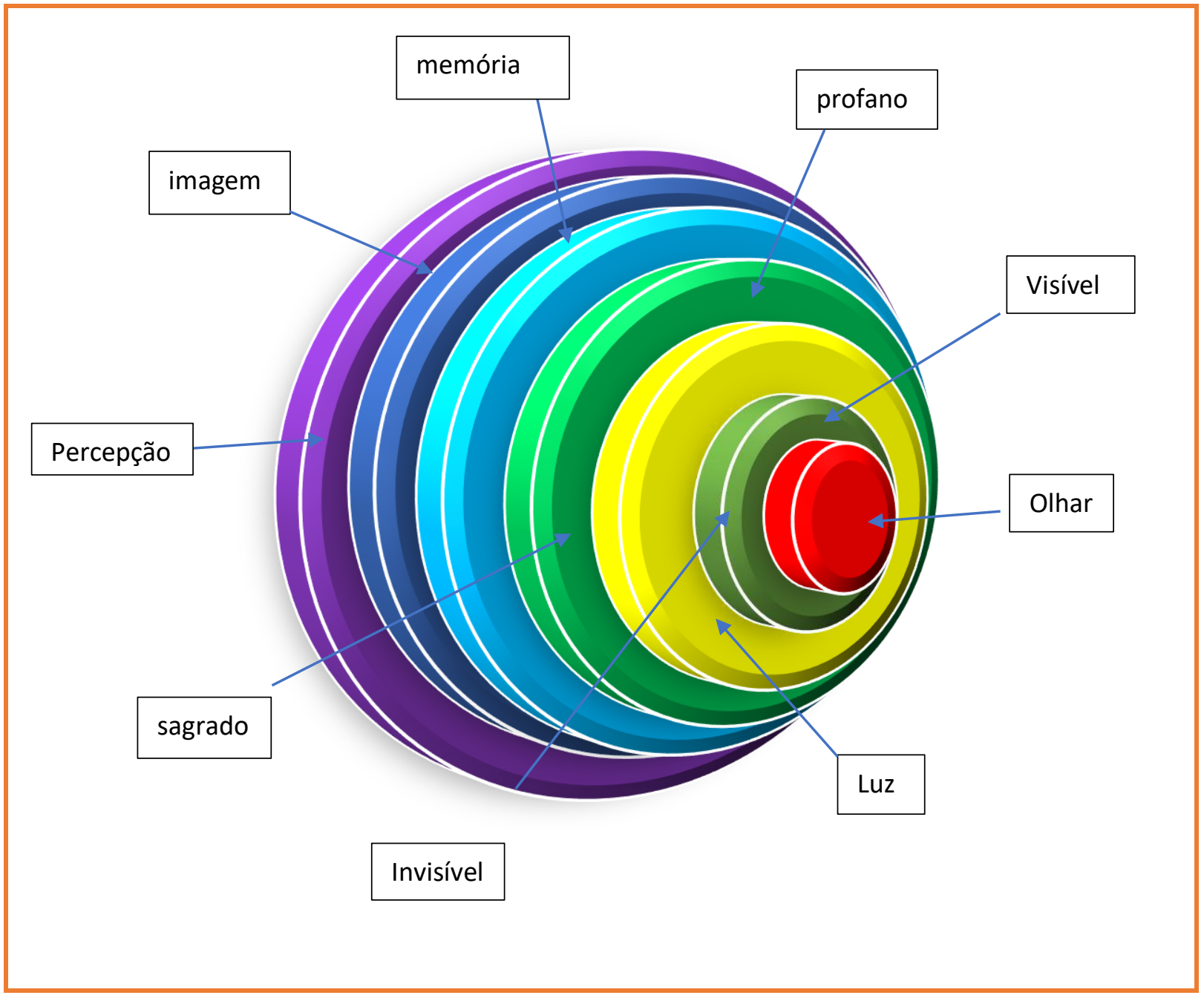

Fonte: a autora 
No interior da esfera, na retina, é onde codificamos a imagem que nos chega invertida. Há três áreas no olho que possibilitam três visões distintas localizadas na retina: acuidade visual, visão periférica e visão noturna. A fóvea central, que reside na mácula, nos possibilita apreciar os detalhes da imagem e diz respeito à acuidade visual, com milhões de células fotossensíveis à luz, os cones, e define nossa sensibilidade de assimilar as cores do espectro, diferenciar a plasticidade e o relevo das formas. Já a visão macular central confere a chamada visão periférica, que nos possibilita ler e perceber profundidades. E a visão escópica, popularmente chamada noturna, se dá pela presença dos bastonetes, células fotossensíveis que estabelecem padrões de luminosidade e nos permitem ver com mínimo de luz.

Desta imagem invertida que nos chega na retina é que estabelecemos uma conexão do nervo óptico com nosso sistema neural. É no cérebro que processamos e interpretamos a imagem. Em sua complexidade, estas operações sinápticas trazidas por milhões de neurônios e receptores sensíveis existentes no nosso cérebro atingem muito mais que nosso sistema ótico e se ramificam por todo o corpo. As pesquisas científicas avançadas na Neurociência a cada dia revelam novas descobertas sobre estas conexões químicas e elétricas, tentando explicar nossa ambiguidade cromática e memórias visuais, e demonstrando avanços no entendimento de como vemos, sentimos e interpretamos o mundo. 


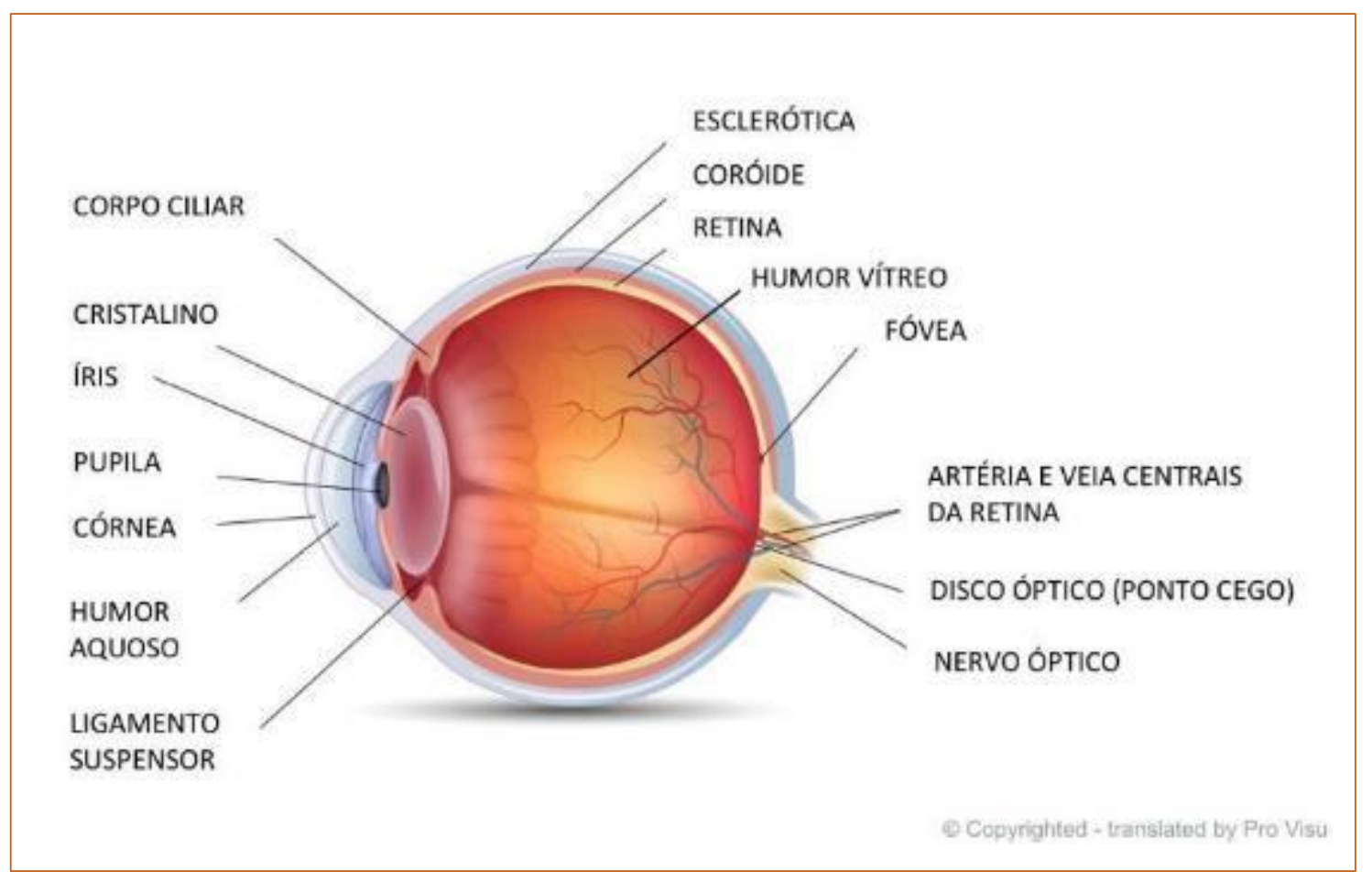

Fonte:<https://www.provisu.ch/pt/component/content/article.html?id=323:olho-e-visao> Acesso AGO2020

A preocupação dos neurocientistas em explicar como percebemos o mundo trava um diálogo mais próximo à filosofia da mente. Contudo, na voz dos neurocientistas, sensação e percepção são fenômenos distintos. A sensação é basicamente a resposta de um receptor sensorial a estímulos externos, ou seja, é uma resposta fisiológica do organismo; um processo em que os sentidos humanos convertem a energia de um estímulo em mensagens neurais e 
provocam reações. A percepção, por outro lado, é o julgamento dado pelo sujeito com base nas informações das sensações. É a interpretação pelo indivíduo acerca do que foi captado pelos sentidos. É um processo que pode ser influenciado por fatores fisiológicos e psicológicos, tanto quanto por questões externas, como aspectos culturais e sociais. Entendem que a percepção está intrinsicamente relacionada à sensação, sendo sua primeira etapa realizada pelos sistemas sensoriais, responsáveis por sua fase analítica. Entretanto, percebem-se objetos integrados como um todo, e não características fracionadas, o que faz supor que existam outros mecanismos, além daqueles de natureza analítica, que colaboram para a formulação da percepção sintética.

A filosofia tem discutido amplamente estas questões, tentando estabelecer os limites científicos e metodológicos de uma ciência que não consegue explicar a percepção apenas por seus componentes biológicos, visto o caráter subjetivo que engloba este processo. A neurociência avança no que a teoria da Gestalt ${ }^{9}$ entabulou no início do século XX, e já há indícios de ser uma ciência empírica, dedicada a revelar os mecanismos cerebrais que nos levam a perceber e compreender o mundo de forma singular, levando em conta componentes subjetivos, neuro cognitivos e neurobiológicos.

${ }^{9}$ Os fundadores da Escola da Gestalt foram Marx Wertheimer, Kurt Koffka e Wolfgang Köhler.[...] Acentuavam o princípio da determinação relacional - isso é, que a propriedade das partes depende da relação entre as partes e o todo; as qualidades das partes dependem do lugar, papel e função que têm no todo. Todos afirmaram também que, na maior parte das configurações, o todo não é igual à soma de suas partes. (WERTHEIMER, 1977, p. 164). 
Reconhece na percepção dos sentidos e na memória como os mensageiros do nosso conhecimento sensível, e muitas pesquisas e estudos de caso vêm sendo realizados por neurocientistas de diferentes áreas de atuação, como a biologia, a física, a medicina, as artes, atentos a questões de como o cérebro constrói a mente e como o cérebro torna a mente consciente, abrindo discussões sobre o que é a consciência.

Não tenho como objetivo traçar um debate acerca da percepção, mas sim reconhecer o quanto o tema percepção sob a perspectiva da filosofia da mente hoje ocupa a ciência. Ao entrar em contato com pesquisas experimentais, percebo que nós, artistas pesquisadores, somos neurocientistas ao nos ocuparmos de descrever nossos processos artísticos. A riqueza de indícios, conjecturas e hipóteses desenvolvidos nestes percursos processuais nas artes reafirmam a complexidade do tema e trazem um legado conceitual importante para esta abordagem científica sobre cérebro, mente e consciência.

Quando me refiro ao olhar e à construção da imagem, o perceber já conota um processo de criação pois, ao percebermos algo, estamos interpretando e simultaneamente fabricando uma imagem ou acessando outras que, dada sua importância, sobrevivem em nós. Na própria concretude da arte temos indícios desta produção e gestão estratégica de imagens, independentemente da linguagem artística.

Hoje, podemos afirmar que somos donos de nossas imagens e que, entre o ver e o olhar existe um amplo campo de suposições multidisciplinares com infinitas possibilidades de criar. 
Na estrutura ocular encontramos correspondências e analogias com dispositivos eletrônicos, reconhecendo a importância dos estudos envolvendo mídias digitais que, apesar de não serem tema da pesquisa, se relacionam com esta interação e hibridização das imagens em arte e tecnologia.

Marcia Tiburi ${ }^{10}$ reflete sobre a televisão e o estado de exceção da imagem, e traz uma argumentação apropriada sobre o ver e o olhar pertinente ao nosso estudo.

Ver torna-se a condição de possibilidade do olhar. Digamos que o olhar está para o ver como a sexualidade para o sexo. Visão e sexo seriam objetividades enquanto olhar e sexualidade seriam subjetivos, seriam elaborações interpretadas. Certamente há um olhar que impõe um ver e um olhar que surge do ver [...] ver seria, assim, o olhar abstraído de subjetividade, posterior e anterior ao próprio olhar. Se o olhar é o que podemos analisar, pois podemos descrever sua antropologia, a metafísica, a estética, a política, se o olhar é o histeron proteron (o anterior que é o posterior, o primeiro que é o último) qualificado fenomenologicamente pela descrição de sua experiência, ver, no entanto é a ação abstraída de sua qualificação, momento aberto da experiência, o que no olhar está suspenso, ver é o verbo que designa algo essencial do olhar.

${ }^{10}$ TIBURI, 2011, p.79 
A filósofa reflete sobre a imagem televisiva e, entre conceitos e metáforas procedentes, pensa na potência da imagem que nos captura, uma visão que se constrói a partir do Olho de Vidro - a televisão. Sua reflexão consiste em investigar este dispositivo visual e a experiência subjetiva vivida por aquele que vê, trazendo conceitos sobre ver e olhar.

Na reflexão de Tiburi, o ver implica no sentido físico da visão, e o olhar se aplica à complexidade do ver. Assim, o ver se relaciona com um ato objetivado, sintético, e o olhar com um ato contemplativo, analítico. As mediações do olhar, por sua vez, colocam-no no registro do corpo: ao olhar vejo algo, já vitimado por tudo o que atrapalha minha atenção, retirando-a da espécie sintética do ver e registrando-a num gesto analítico que me faz passear por entre estilhaços e fragmentos e, em algum momento, compor um todo.

O olhar mostra que não é fácil ver, e que é preciso ver, ainda que isso pareça impossível, pois no olhar, o objeto visto aparece em seus estilhaços de ser, e só com muito custo se recupera a síntese que possibilita reconstruir o objeto. É como se depois de ver fosse necessário olhar, para então, novamente ver.

Há, assim, uma dinâmica, um movimento - e, segundo Tiburi, um ritmo no processo de olhar-ver. Ver e olhar se complementam, são dois movimentos do mesmo gesto que envolvem sensibilidade e atenção ${ }^{11}$.

Interessa analisar o olhar neste contexto subjetivo que alimenta luz e imagem, uma constituinte da outra. Também nos importa verificar o espaço que delimita a experiência.

\footnotetext{
11 TIBURI, 2013
} 
Não bastam um observador e um objeto para que aconteça o processo perceptivo, mas sim a transformação do objeto em fenômeno. Entre nós e o objeto há um espaço intermediário, e é neste espaço que as coisas se tornam sensíveis - assim, o encontro entre olhar, imagem e luz acontece neste vão. O olhar, quando emoldura um campo recortado pelo interesse da visão, permite um entrelaçamento entre a percepção e a recepção. Esta recepção se dá em relação ao objeto, e dois ângulos precisam ser revisitados. Neste ato entre receber-olhar e olhar-receber há um lugar preenchido por camadas.

Sobre o espaçamento entre a percepção e a recepção num contexto filosófico - o qual implica também no não ver, no invisível do objeto agregado à experiência - percorro alguns paradigmas levantados por Georges Didi-Huberman, filósofo francês e historiador de arte dedicado ao estudo da imagem, quando integra duas redes conceituais benjaminianas: aura e imagem dialética ${ }^{12}$. Desta distância entre o que olha e o que é olhado, o autor revisita e reformula o conceito de Walter Benjamin ${ }^{13}$, como um

12 "O conceito de aura permite resumir essas características: o que se atrofia na era da reprodutibilidade técnica da obra de arte é sua aura. Esse processo é sintomático e sua significação vai muito além da esfera da arte. Generalizando, podemos dizer que a técnica de reprodução destaca do domínio da tradição o objeto reproduzido. Na medida em que ela multiplica a reprodução, substitui a existência única da obra por uma existência serial. E, na medida em que essa técnica permite à reprodução vir ao encontro do espectador, em todas as situações, ela atualiza o objeto reproduzido. Esses dois processos resultam num violento abalo da tradição, que constitui o reverso da crise atual e a renovação da humanidade." (BENJAMIN, 1994, pp. 168-169)

${ }^{13}$ A obra de arte na era da reprodutibilidade técnica, de Walter Benjamin (1994), no qual o autor analisa as alterações provocadas pelas novas técnicas de produção artística na esfera da cultura, e desenvolve, como elemento principal, a tese de a reprodutibilidade técnica provocar a superação da aura pela obra de arte. 
espaçamento tramado do olhante e do olhado, do olhante pelo olhado. Sobre este paradigma visual apresentado por Benjamin com uma trama singular de espaço e tempo, Huberman, sempre atento às relações entre linguagem e visualidade, reflete sobre a ambivalência das imagens neste ritmo de perto e distante. Para ele, a aura se configura a partir de uma questão de distância, e é exatamente essa relação entre distâncias do que vemos e a imagem que nos olha que se constitui a essência da aura. Nesta releitura dos conceitos de aura e duplicidade do olhar já trazidos por Benjamin, amplia-se a noção do ato de ver as imagens como um encontro entre o receptor e a obra de arte, postulando uma abordagem epistemológica das imagens de arte.

[...] O ato de ver não é o ato de uma máquina de perceber o real enquanto composto de evidências tautológicas. O ato de dar a ver não é o ato de dar evidências visíveis a pares de olhos que se apoderam unilateralmente do 'dom visual' para se satisfazer unilateralmente com ele. Dar a ver é sempre inquietar o ver, em seu ato, em seu sujeito. Ver é sempre uma operação de sujeito, portanto uma operação fendida, inquieta, agitada, aberta entre aquele que olha e aquilo que é olhado. ${ }^{14}$

\footnotetext{
${ }^{14}$ DIDI-HUBERMAN, 2010, p.77
} 
Tanto para Didi-Huberman como Benjamin, tais distâncias se experimentam através da dialética da proximidade e da distância, proximidades sensoriais e distâncias significantes. Portanto, a aura para ambos é uma instância intrinsecamente dialética.

A partir deste paradoxo de o que está sob nossos olhos e fora de nossa visão, Benjamin diz: "Sentir a aura de uma coisa é conferir-lhe o poder de levantar os olhos" e acrescenta: "Esta é uma das fontes mesmas da poesia"15. O poder do olhar no paradigma visual atribuído por Benjamin está nas relações de tempo, distância e ausência, um espaçamento tramado, como revela o filósofo.

O que nos interessa é o olhar que consterna e constrange, na medida em que desnuda e solicita sensibilidade. Um exemplo simples: em lindos olhos e lindo olhar percebe-se como estas expressões se diferenciam e complementam. Ao olharmos profundamente os olhos de alguém abstraímos outras impressões subjetivas, e ao olhar para nós mesmos elevamos nossa capacidade de ver. A expressão de Leonardo da Vinci, "O olho é uma janela para a alma", revela este sentido amplo de que ver é olhar para si.

Sobre estar diante da sua imagem, encontramos nas metáforas de imagens especulares descritas por vários autores a profundidade do ato de ver como um processo de percepção de si para compreender o todo.

\footnotetext{
${ }^{15}$ BENJAMIN apud DIDI-HUBERMAN, 2010, p.197
} 
Tomo como exemplo Giorgio Agamben ${ }^{16}$, filósofo italiano, quando se refere à imagem íntima, também marcada pela ambiguidade da percepção de si,

[...] A espécie de cada coisa é a sua visibilidade, a sua pura inteligibilidade. O ser especial é absolutamente insubstancial. Ele não tem lugar próprio, mas acontece a um sujeito, e está nele como um habitus ou modo de ser, assim como a imagem está no espelho. Especial é o ser que coincide com o fato de se tornar visível, com a própria revelação. O espelho é o lugar onde descobrimos que temos a imagem e, ao mesmo tempo, que ela pode ser separada de nós, que nossa espécie ou imago não nos pertence $[\ldots]^{17}$

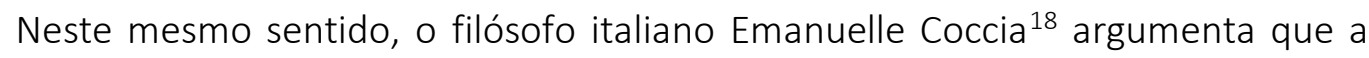
experiência do espelho tem a ver com o fato de que o sujeito não se torna objeto de si mesmo, mas ele se transforma em algo puramente sensível, cuja única propriedade será a de ser sensível, uma pura imagem, sem corpo e sem consciência. É a própria imagem e é o fora absoluto, visto que está além do seu ser. Nossa forma se transforma na imagem quando se torna capaz de viver além de nós, e passa a viver sobre a superfície das coisas.

\footnotetext{
${ }^{16}$ Em Profanações, Giorgio Agamben reflete sobre a recuperação da potência humana no sentido de experimentar e resgatar a própria existência, e que profanar o sagrado significa devolver à comunidade humana aquilo que historicamente foi subtraído do uso comum através da sacralização.

${ }^{17}$ AGAMBEN,2007

${ }^{18}$ COCCIA, 2010
} 
Ambos filósofos argumentam que estar diante de sua própria visibilidade e de si mesmo como ser puramente sensível pressupõem que esta imagem existe em outro lugar, não aquele onde se encontra o sujeito que conhece e o objeto do qual ele é a visibilidade.

Coccia reflete sobre o lugar das imagens como parte deste espaço suplementar, que não é nem o espaço do objeto e nem do sujeito, e sim o sensível, o corte entre a forma do objeto e o lugar de sua existência e consciência. O ser da imagem é forma que está fora do sujeito natural, e ainda é o ser da estranheza, um estrangeiro. Assim, para ele, a imagem é a experiência da exterioridade. Essa forma que vive fora o faz com tanta potência que indica os estilos da vida ordinária, isso porque vivemos sob a perpétua influência do sensível: cheiros, cores, sensações olfativas, sons.

$$
\text { Nossa existência - dormindo ou em vigília - é um }
$$
mergulho ininterrupto no sensível. São sensiveis - as imagens das quais não deixamos de nos nutrir e que não param de alimentar nossa experiência diurna ou onírica - que definem a realidade e o sentido de todo nosso movimento. ${ }^{19}$

Coccia reflete que "[...] a imagem é o sensível, o homem é o sensível, portanto o homem é imagem ou vive como uma imagem. [...]"20. Para ele, a natureza da vida é a

\footnotetext{
${ }^{19}$ COCCIA, 2010, p.38

${ }^{20}$ Ibidem, p.39
} 
imagem, cujo efeito é a semelhança, condição para que se reproduza, transmita, se movimente e, assim, viva.

Diante da imagem, Hubermann afirma que elas são ao mesmo tempo materiais e psíquicas, externas e internas, espaciais e de linguagem, morfológicas e informes, plásticas e descontínuas. "[...] As imagens solicitam primeiramente o olhar, mas também o saber, a memória, o desejo e sua sempre disponível capacidade de intensificação. Isso quer dizer que elas implicam na totalidade do sujeito, sensorial, psíquico e social [...]"21.

É neste jogo dialético que constitui as imagens que nos detemos num duplo olhar para delas e criamos outras imagens onde o sensível é este fluxo de adensamento perceptivo.

Para Henri Bergson a imagem se constitui nas relações entre a matéria e a memória. Portanto a nossa mente e o mundo são constituídos de imagens e a matéria para Bergson é este conjunto de imagens e de percepções da matéria. Assim, considera que neste mundo das imagens o corpo por ser matéria é também uma imagem que atua com outras imagens através daquilo que percebe com os sentidos. O corpo, portanto, é um centro de ação.

Merleau-Ponty traz para o corpo este fluxo das imagens como a única e verdadeira consistência daquilo que chamamos vida; isso porque é o nosso o corpo que se define a partir de uma atualidade de percepções, e acrescenta que, na experiência perceptiva, é preciso criar estes espaços que constituem nosso campo de visão entre imagem e corpo.

\footnotetext{
${ }^{21}$ DIDI-HUBERMAN, 2010
} 
Ao atribuir aura como o espaçamento entre o olhar e a experiência, onde imagem e luz se fundem, penso desenhos dos labirintos, suas formas cheias de bifurcações e caminhos intrincados, forjados para nos desorientar, para nos perder entre os possíveis caminhos que também pode significar a trajetória sensível da percepção e da criação de imagens. Nesse processo singular, movido pela percepção aguda e a descoberta do sensível, se constitui o trabalho do artista, em cujos labirintos, ele pode experimentar, escolher, seguir e chegar. O minotauro do mito cretense é o dilema a ser resolvido pelo artista. Os labirintos assim, aguçam o mistério das coisas, as memórias e as metáforas que nos movem de estados de inércia, do impulso ao desejo e do fluxo aos movimentos. Mas, também, nos remetem ao jogo, ao lúdico, à construção de narrativas que se assemelham às dramaturgias performativas, atravessadas pelas fagulhas de vida. As direções escolhidas são como passos a se seguir na vida, mas também, descrevem o modo como as etapas dos processos transformam a obra de artistas de qualquer campo. Desse modo, me vejo tendo que fazer escolhas e tomar direções, cometer equívocos e boas descobertas. A percepção é uma escolha.

Diante disso, identificando na ação do ver e do olhar a elevação do processo de consciência perceptiva é que reflito sobre as práticas artísticas e o espaço onde construímos nossas imagens sensíveis. Neste povoado imagético que é o mundo, ativamos nossa potência de recepção para percebê-lo prospectando o fazer artístico. É 
nesse lugar que nossas imagens nasceram e tomaram forma - um entre espaço - onde corpos exteriorizam seus estados internos e se inter-relacionam com outras imagens.

Na intenção que trago de traduzir uma poética, a experiência estética individual passa a ser a percepção, um caminho que deflagra um encontro íntimo que serve de base informativa no processo artístico.

Na provocação “o que é luz para mim?", procuro um sentido para este feixe de fótons através do meu olhar sobre ele. O meu olhar defino como todos os movimentos possíveis percorridos através da minha percepção, sensações, memórias e experiências. À luz não ouso atribuir nenhum conceito, admito apenas que ela representa a substância de contato entre o corpo e a imagem. 


\section{PONTO DE INTERSECÇÃO 1 - AS VERTIGENS}

O labirinto é essencialmente um entrecruzamento de caminhos, dos quais alguns não tem saída e constituem assim impasses; no meio dele é mister descobrir a rota que conduz ao centro desta bizarra teia de ranha. A comparação com a teia de aranha não e aliás exata, porque a teia é simétrica e regular, enquanto a essência mesma do labirinto é circunscrever no menor espaço possivel o mais completo emaranhamento de veredas e retardar assim a chegada do viajante ao centro que deseja atingir.

- Leonardo da Vinci

Labirintos contêm em si uma forma física e espacial de estrutura simbólica e metafórica e, por analogia, se integram à peculiaridade da pesquisa que traz no seu íntimo a incerteza e conduz a pesquisadora ao interior de si mesma, a uma viagem iniciatória em busca do sagrado e mistério da luz, à revelação de algo a ser descoberto, ao sentido de transformação e evolução pessoal no movimento espiral que conduz ao infinito. Como as imagens nos chegam com todas as variedades sensoriais e, não apenas visuais, elas dizem respeito a qualquer objeto ou ações que processamos em nossa subjetividade, sejam elas íntimas ou não. Isso ficou mais evidente, principalmente na prática hierofanias. As palavras surgidas nos relatos se apresentavam num trajeto espiralado, imagens aparentemente desconexas entre si. Dar algum sentido a esse desenho circundante de palavras e imagens emaranhadas e desordenadas que, por 
vezes, paradoxalmente, andavam juntas, se entrelaçavam e giravam literalmente exigiram que revisse as relações entre meu conhecimento sobre e com a luz e o modo de descrever minhas experiências, sem perder a conexão com as dinâmicas e alguns desequilíbrios que a vida e meu corpo sugeriam.

Deste movimento de narrativas das experiências, concomitante com um processo corporal que se manifestava em mim, surgiram vertigens causadas por disfunções do ouvido. Flutuantes, as ondas de vertigens chegaram sem aviso e confesso que me assustaram muito. No início, fiz uma romaria por vários otorrinolaringologistas e este estado foi diagnosticado fisiologicamente como um problema no Labirinto, mas sem respostas quanto à causa dos sintomas. Suposições: stress, metabolismo etc. Este episódio aconteceu quatro meses antes do depósito da minha qualificação. Quando somos surpreendidos por algo, queremos de imediato contrapor com algo que nos conforte, neste caso uma resposta precisa: um remédio, um caminho, uma prece. Num primeiro momento interrogamos fora em busca de respostas.

Sempre acreditei em coincidências, o que mais tarde associei com sincronicidade 22 , e hoje entendo que o movimento dos meus olhos, do meu corpo e do meu pensamento fazem vibrar algo no mundo e em mim. A representação do labirinto, com sua estrutura mítica, ritual e poética, desafiou minha imaginação. Nestes

\footnotetext{
${ }^{22}$ A sincronicidade é o princípio que Jung postula como o elo entre a psique e o evento numa coincidência significativa. É o participante que determina (através de sentimentos meramente subjetivos). (BOLEN, 1979)
} 
cruzamentos entre palavras, experiências e meu corpo físico, encontrei um ponto de intersecção. Assumi a existência de um labirinto dentro de mim e precisava conhecê-lo fisicamente, já que ele sugeria um movimento de desorientação pelos percursos intrincados da imagem dos labirintos nas práticas e do meu corpo, e precisava estabelecer um equilíbrio entre eles.

Na ótica fisiológica, labirinto é a região da orelha interna ligada à audição, à noção de equilíbrio e à percepção da posição do corpo. É dividido em duas partes: o labirinto posterior e o anterior, constituído por um tecido ósseo e outro membranoso, em formato de 'caracol' e abrigando um líquido viscoso (endolinfa) entre as duas camadas. No interior de nossa orelha, mais precisamente em nossa orelha interna, o aparelho vestibular, também conhecido como labirinto, é formado pelo utrículo, o sáculo e os canais semicirculares. O utrículo e o sáculo se localizam sobre a cóclea, e são bolsas repletas de substância gelatinosa, cujas paredes são constituídas por células sensoriais sobre as quais encontram-se os otólitos, pequenos grãos de carbonato de cálcio. Quando nosso corpo se movimenta, a força da gravidade atrai os otólitos que se encostam nas células sensoriais, gerando impulsos nervosos que são enviados ao cérebro, permitindo determinar a real posição da cabeça em relação à força gravitacional. Dessa forma, podemos perceber em que posição estamos. Os canais semicirculares são formados por três regiões dilatadas acima do utrículo. Nessas dilatações, ou ampolas, existem células sensoriais ciliadas cobertas por um líquido gelatinoso. Ao movimentarmos nossa cabeça, 
o líquido no interior dos canais semicirculares faz pressão sobre as células sensoriais ciliadas que serão estimuladas e geram estímulos que serão enviados ao cérebro. Se uma pessoa gira o corpo, o líquido dos canais semicirculares também se movimenta, e isso diminui a pressão sobre as células sensoriais. Quando a pessoa para de girar, o líquido dos canais semicirculares continua a se movimentar em razão da inércia, estimulando as células sensoriais e causando aquela sensação de tontura. Essa sensação ocorre porque as células sensoriais enviam ao cérebro mensagens de que o corpo está se movimentando, mas os olhos informam que o nosso corpo parou de girar, gerando um conflito de informações que resulta em tontura. Dessa forma, conclui-se que os olhos também participam do sentido do equilíbrio, pois informam ao cérebro a posição do corpo através de imagens captadas do ambiente.

Recebi diagnóstico de VPPB - vertigem posicional paroxística benigna. Traduzindo: meu estado sintomático indicava que a movimentação dos otólitos nos canais semicirculares estava desajustada. O labirinto é como uma antessala que separa a área auditiva da área do equilíbrio. O curioso é que este espaço tem a forma espiralada com algumas bifurcações onde minúsculos grãos de carbonato de cálcio, atraídos pela gravidade, se movimentam e conversam com nossas células sensíveis que se comunicam com nosso cérebro para equilibrar novas posições assumidas pelo corpo. É através destes movimentos líquidos nesses trajetos que conseguimos detectar a posição da nossa cabeça e manter o equilíbrio do corpo. São movimentos verticais e horizontais para cima 
e para baixo; e horizontais, para a direita e para a esquerda, para frente e para trás. Ao pesquisar sobre este tema não encontrei nenhuma relação científica com os labirintos mitológicos mas encontrei , num livro de neurociência uma exemplificação interessante sobre o assunto : Uma bailarina fixa o olhar num ponto fixo para manter o equilíbrio, a cabeça deve ser a última a sair do giro e a primeira a voltar, fazendo com que o labirinto se adapte aos movimentos bruscos e repetitivos e, de novo, veio a imagem da bailarina, ereta e rodopiando no relógio. Sincronicidades...

Por alguma razão até então enigmática, os otólitos estavam desgovernados no meu labirinto e não encontravam um centro de equilíbrio para se estabilizar, e o mais curioso é que isso tinha afetado os canais verticais, horizontais e laterais, o que era incomum, e nas bifurcações deste labirinto eu estava entre idas e voltas. Constatei que era eu que estava em círculos, pensava em círculos, os trajetos das práticas eram circulares, desenhava espirais, as dúvidas giravam durante as escolhas e direcionamentos, e eu não parava de girar. Associei este corpo estranho aos percursos no meu modo de performar com a luz e com os corpos, e no modo como eu incorporo as formas inusitadas que emergem em todos os meus registros de criação e da minha existência.

Henri Bergson me ajuda a absorver o melhor desta situação e perceber certa poética dos labirintos:

Diante do espetáculo dessa mobilidade universal, alguns de nós serão tomados de vertigem. Estão acostumados à terra firme; não conseguem se acostumar com o caturro e a arfagem. 
Precisam de pontos fixos aos quais amarrar as ideias e a existência. Acreditam que, se tudo passa, nada existe; e que, se a realidade é mobilidade, ela já não é no momento em que a pensamos, ela escapa ao pensamento. O mundo material, dizem, ele vai se dissolver e o espírito se afogar no fluxo torrentoso das coisas. Podem ficar tranquilos! A mudança, se consentirem em olhar para ela diretamente sem véu interposto, logo Ihes aparecerá como o que pode haver de mais substancial e duradouro no mundo. Sua solidez é infinitamente superior à de uma fluidez que não passa de um arranjo efêmero entre mobilidades. ${ }^{23}$

Desafiada por este corpo estranho, vertiginoso e inusitado, não próprio de terras firmes, conversei com ele associando-o ao olhar por uma fresta e ao estar entre dois mundos, o que me possibilitou uma viagem aos sentidos. Mais uma vez, a sensação de estar 'entre' uma coisa e outra me levava a perceber e incorporar os estados preliminares no meu modo de criar. São fatos extra artísticos que, paradoxalmente, me permitem devanear entre as realidades, vistas por outros ângulos e descritas de modo não linear.

Existe uma identificação do labirinto no estado presente nas ações, nas escrituras e no meu próprio olhar para a geografia do espaço da pesquisa prática. Simultaneamente, revela o processo investigativo em sua complexidade sobre a potência do olhar, as

\footnotetext{
23 BERGSON, 2006, p.17
} 
relações com a escrita criativa e as camadas subjetivas, perfazendo uma espécie de viagem pelo túnel do tempo. A pesquisa toma forma de um clássico e vasto labirinto no qual, assim que se entra, só resta chegar ao centro e depois encontrar a saída. Tudo fez sentido. Como a organização de um sistema vivo e complexo, onde a mente e a consciência não são coisas, e sim processos, e a cognição se organiza pela percepção através dos sentidos, emoções e comportamento envolvendo todo o processo da vida. Com o tempo, quando meus giros internos foram encontrando seus trajetos, meus otólitos também começaram a se organizar e arranjar novamente pouso no labirinto. Estas analogias, metáforas e conexões entre os labirintos e os espaçamentos e camadas do meu olhar e dos performers me auxiliaram a compreender os percursos da poética e da organização desta pesquisa.

O Labirinto de luz e suas bifurcações representam os percursos criativos imagéticos realizados por mim (pesquisadora) e colaboradores performers em práticas artísticas experimentais: O jardim de luz e Hierofanias. 
BIFURCAÇÃO III - O JARDIM DE LUZ

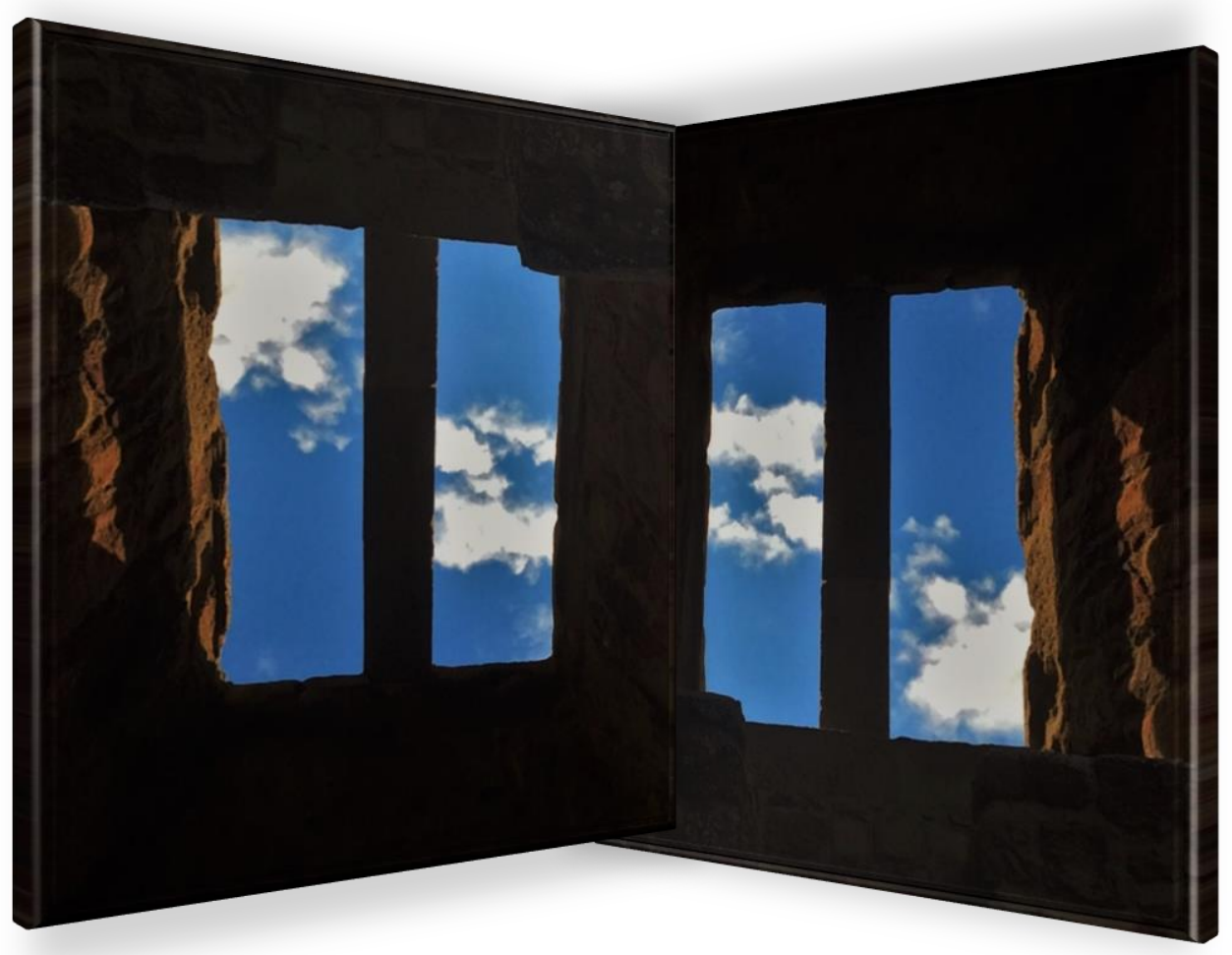


No final de 2015, quando ingressei no programa de doutorado na ECA/USP tive que me mudar para São Paulo. Etimologicamente, a palavra mudança tem sua origem no verbo latino mutare e significa "mudar, trocar de lugar, alterar". Pode parecer simples quando se trata de um mero deslocamento espacial e geográfico, mas um movimento de mudança é complexo e pode implicar em muitas coisas quando se trata de modificar um padrão e as referências. Mudança requer adaptação, desapego e vontade.

Na ocasião, fui viver num espaço bastante compacto, um estúdio de $35 \mathrm{~m}^{2}$ no $18^{\circ}$ andar de um prédio no Bairro Campos Elíseos. Foi uma significativa alteração na relação com o espaço, pois até então havia vivido em lugares amplos. A princípio, tudo parecia não caber, eu mesma parecia não caber, e concluí que espaço é relativo, assim como o olhar.

Olhamos aquilo que queremos ver, fazemos escolhas e há muito para ver se nos esforçarmos um pouco. Não existe uma equação fechada no ato de ver, pois as coordenadas são flutuantes, não exatas, subjetivas. A posição do olhar do observador frente a algo é incerta e complexa. Num primeiro momento, olhava para o espaço físico e a alteração brusca e contrastante das referências que trazia comigo de viver em residências mais amplas. Os limites que o espaço impunha ao meu corpo, reduzindo meu deslocamento, e a sensação de estar comprimida, sufocada, geraram angústia. Na 
perspectiva liminar, portanto, o estar atento a outros movimentos faz reconhecer estas camadas invisíveis em nós mesmos e naquilo que vemos.

Lembro do cenógrafo francês Jean-Guy Lecat, numa de suas vindas ao Brasil para um Seminário de Design Cênico em Curitiba em 2016, propôs aos participantes visitas a alguns espaços teatrais da cidade para discutir questões de arquitetura cênica e cenografia. Entre reflexões e conversas, ele relatou um de seus rituais antes de iniciar qualquer trabalho ou interferência num espaço cênico. Tratava-se de um ritual para aguçar a nossa capacidade de escuta. Sempre que ele ingressava num espaço, o fazia só, caminhava por ele, escolhia um lugar e ali ficava. No silêncio, ouvia o que o espaço tinha a Ihe dizer e somente depois desta escuta passava a dialogar e interferir nele.

O relato de Lecat me levou a associar àquilo que Didi-Huberman identifica como espaçamento invisível, a duplicidade do olhar, a presença da aura. Quando silenciamos internamente, criamos um campo perceptivo fenomenal, ativamos a percepção multissensorial. Resolvi silenciar, conversar com aquele espaço, expandir essa relação.

Com esta provocação, me conectei com as janelas, e eram duas, gêmeas. As janelas estavam orientadas para o leste com uma visão de 180 graus por onde avistava o bairro Bom Retiro e grande parte do centro de São Paulo. As janelas, além de aberturas, têm muitas conotações simbólicas e perspectivas metafóricas. Lendo um artigo do historiador alemão Hans Belting ${ }^{24}$ - "A janela e o muxarabi”, encontrei duas perspectivas

\footnotetext{
${ }^{24}$ A Janela e o Muxarabi: uma história do olhar entre Oriente e o Ocidente. In: ALLOA, 2017, p.115
} 
interessantes sobre as janelas que se referem à visão do olhar entre o Oriente e o Ocidente. Belting traça uma visão histórica sobre a janela como forma simbólica no Ocidente desde as noções de perspectiva trazidas por Leonardo da Vinci até os dias de hoje. O arquiteto italiano Leon Battista Alberti transpõe a conhecida metáfora de Da Vinci "O olho é a janela da alma" para o quadro, descrita por ele como uma janela. O globo ocular, do exterior, é um espelho redondo sobre cuja superfície o mundo circundante se reflete. Através da abertura escura da pupila, o olhar se volta para o exterior, como que a partir de uma janela ${ }^{25}$. A metáfora apresentada por Alberti incita o arquiteto a calcular precisamente as janelas de uma construção do olhar em relação ao olhar, pois, segundo ele, "não vemos a luz com os pés, mas com o olho" 26 .

Para Belting, enquanto o quadro torna explícito o olhar sobre o mundo, também indica a posição do espectador. A oposição entre interior e exterior constitui propriamente uma lei da história da imagem ocidental. O mundo é um mundo a ser visto e se abre ao olhar por detrás de uma janela simbólica ${ }^{27}$. O historiador aborda alguns pontos de vista sobre a história da imagem na janela na cultura ocidental, concluindo que a janela e o olhar pela janela são indissociáveis e que, de forma simbólica, a perspectiva concentra-se na ideia

\footnotetext{
${ }^{25}$ ELKINS apud BELTING, 1994, p.116

${ }^{26}$ ALBERTI apud BELTING, 1994, p. 59

${ }^{27}$ BELTING, 1994, p. 116
} 
de representar o sujeito em seu olhar. Para ele, na perspectiva da história do olhar Ocidental, é diante da janela que se decide a relação com o mundo.

Na cultura árabe, por exemplo, a interpretação da janela tem uma conotação muito diferente, o olhar, bem como, a perspectiva, parecem ausentes. A ideia de uma janela pela qual o olhar atravessa é fundamentalmente oposta na cultura islâmica. Há um outro ponto de vista, uma mudança de perspectiva que, certamente está associada às especificações da cultura oriental. O olhar ocidental dirige-se às imagens para além da janela, portanto, a visibilidade do mundo surge de um olhar do interior para o exterior. No mundo islâmico, uma tela é construída neste limite. Esta tela é o suporte para a criação artística e não existe para o olhar e sim para a luz, por meio da qual se inverte a relação entre interior e exterior. Mesmo que consideremos que as janelas existem para a entrada da luz, para os árabes esta encenação da luz tem uma simbologia própria, pois a forma como ela invade o espaço das habitações árabes provoca interiorização, fazendo com que o olhar seja atraído pela reflexão da luz e não aviste ou se distraia com o exterior. As janelas são grelhadas de forma a separar o interior do exterior. Assim os habitantes avistam as ruas sem ser vistos. Segundo Alhazen ${ }^{28}$, a luz somente circula pelo mundo por intermédio dos raios que ela mesmo emite; a tela geométrica submete a essa luz uma ordenação que a torna mensurável e atrai o olhar em sua direção. A luz deixa-se regular

\footnotetext{
${ }^{28}$ Abu Ali al'Hasan conhecido também pela forma latinizada Alhazen, nasceu no ano 965 em Baçorá, hoje Iraque, e morreu em 1040 na cidade do Cairo. Foi um dos primeiros a explicar o fenômeno dos corpos celestes no horizonte.
} 
pela geometria da decoração da janela, sem suscitar imagens e atua de modo ainda mais puro e abstrato do que no mundo exterior, onde está misturada às cores e submetida às formas das coisas.

A delimitação da luz pela tela desfaz a união entre os raios de luz e os raios do olhar. Isso a libera na cintilação do reflexo, restituindo sua essência própria. Belting exemplifica com algumas obras arquitetônicas do egípcio Hassan Fathy, cujo trabalho incorporou o muxarabi (macharabiyya), uma antiga forma de janela islâmica que também adornava as varandas das casas, caracterizada por uma tela em treliça de madeira. Para o arquiteto Fathy, luz torna-se aqui um tema de geometria da própria luz. O muxarabi pertence à história da arquitetura islâmica e marca também as casas da população árabe rural. Esta janela é uma composição de luz e sombra que impede o ofuscamento da luz do sol e dissolve a superfície da parede no espaço interno; ao longo do dia, vão sendo projetados diferentes motivos com o movimento da luz. É uma janela de luz. "A direção da luz acontece num sentido bastante especial; a luz 'entra em cena' como uma potência cósmica, uma vez que percorre o interior ao ritmo das horas do dia" 29.

Estas diferentes mudanças de perspectivas que Belting descreve sobre o olhar através das janelas, ao analisar o muxarabi e a janela ocidental, podem ser compreendidas nas diferentes visões de mundo dadas pela cultura.

\footnotetext{
${ }^{29}$ FATHY apud BELTING, 1994, p.131
} 
Assim, torna-se interessante para minha prática pensar em diferentes perspectivas: uma em que o olhar do observador é ativo, suscita as imagens; o outro vivencia o fenômeno através da luz. A simbologia do muxarabi (fig.3) em capturar a luz denota uma sensibilidade e pureza à imagem do mundo exterior, estabelecendo outra relação entre olhar e luz que me fez refletir sobre o processo de criação das imagens nas minhas janelas. Por identificar a alternância deste duplo ponto de vista do olhar, por momentos, creio que estas invisíveis telas se materializavam e a luz penetrava e comandava.

As janelas simbolizam um espaço do espaço onde articulo os atravessamentos.

Figura 3-Muxarabi

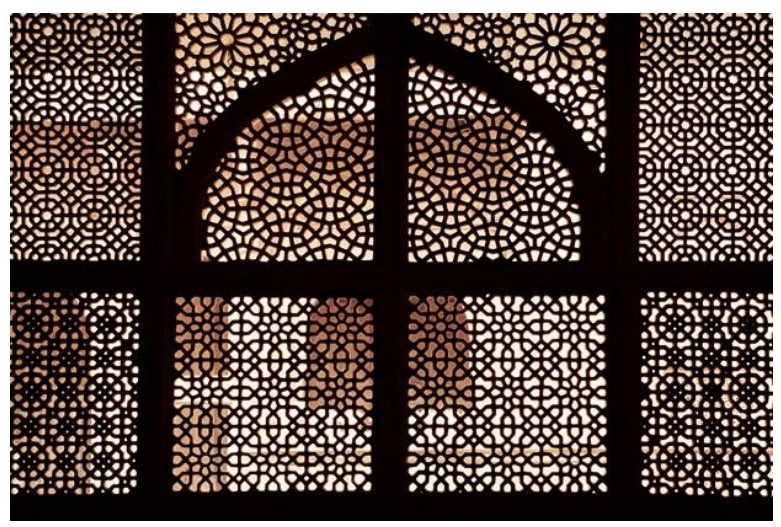

Disponível em: http://grunstudio.com.br/elementos-vazados-na-arquitetura-cobogo-e-muxarabi/ 
Antes de se tornar uma prática, estas ações na janela surgiram na primeira semana após minha mudança, ao despertar matutino, inverno, por volta de 5 h45min, quando fui surpreendida pelo fenômeno do alvorecer que quebrou a sinergia dos meus olhos recém despertos e roubou por inteiro a minha atenção. São estas experiências de luz-fenômeno que, nas suas intervenções espaciais, resgatam nosso princípio cósmico de existir na natureza. Percebi nesta interação artista-luz-espaço, uma possibilidade de ampliação do lugar. Neste espaçamento sensível e subjetivo que se estabelecia com o mundo exterior na proposição de viver uma experiência total do lugar e do espaço, com a interferência do olhar sobre ele. Durante quase dois anos, observei o fenômeno da luz com atenção flutuante através da janela, e construí um avanço que vim a chamar de jardim de luz.

Neste prolongamento onde imagens me 'espiavam' diariamente, outras imagens apareciam e, assim, passei a regá-las como se faz com as flores. Desta interação diária estabeleceu-se uma relação íntima, de troca de múltiplos afetos, éramos uma família: eu, o jardim, a luz e as flores. Havia dois movimentos simultâneos, o do meu olhar e as imagens que me espiavam. A intensidade desta convivência despertou a necessidade de trazer uma corporalidade ao processo.

Num livre exercício provocativo de registrar as experiências, instalei minha câmera fotográfica em frente a uma das janelas e adotei a persona de voyeur. Invadindo 
a privacidade da luz, passei a investigá-la. Difícil explicar o que sentimos num movimento que parece tão simples e cotidiano - a trajetória do sol sobre uma paisagem fixa, mas a experiência reverberou numa proporção significativa e desafiadora na origem das composições, sobre as escolhas do olhar, minhas memórias de luminosidade e sistemáticas do uso da luz em meus processos artísticos. As janelas passaram a ser um espaço de intermediação transparente, um lugar de passagem e comunicação de cenas e estados íntimos.

A princípio, o ato fotográfico como linguagem estava afastado da minha prática, mas passei a experimentar como uma nova forma de expressão com a luz, uma fotografia experimental ou performance do olhar, sem preocupações com uma representação técnica, e sim com o acontecimento visual e a experiência perceptiva. Um olhar transparente como membrana anexa ao meu olho. Uma outra experiência da imagem. Assim nasceu a primeira 'flor' que compôs a série denominada a posteriori de "Tem Luz em Sampa".

A cidade antes avistada por mim não era mais a mesma. Agora, outra luz se apresentava e se comunicava por entre a silhueta dos prédios, com a paleta cromática do céu, com os desenhos das nuvens e do meu espaço íntimo. A revelação e a compreensão do eu fenomenológico, me colocou diante de uma certeza natural da manifestação da primeira camada do conhecimento sensível, o olhar, e junto à possibilidade de a luz constituir uma materialidade para o que via e sentia. Poder dar forma ao momento em que a matéria pode ser outra imagem articulada a uma realidade cotidiana. 
Durante as quatro estações, período em que permaneci nesse estúdio, persegui a luz e comecei a dar forma ao sensível através das janelas. Esta prática artística ocasionou uma experiência profunda de convivência e sobrevivência naquele espaço. Com o tempo, comecei a plantar instalações com alguns objetos caseiros que, como visitas nas janelas, assumiam outros significados. A performance do sol reconfigurava diariamente o espaço, os objetos em cores, as formas e seus contrastes. A luz toma a forma das coisas e do ambiente. Os recortes de luz que antes eu usava na cena como significado de uma ação agora eram recriados num outro espaço, o mundo que eu via. A imagem, portanto, existia além de mim e passava a existir na superfície de outras coisas. Um dia diferente do outro, assim é a vida, assim é a luz e assim é a imagem, com o olhar sensível que reside em nós.

Debrucei-me sobre as imagens fotográficas como representações reais e testemunhas da experiência sensível, numa base perceptiva e fenomenológica. Os acontecimentos visuais autônomos e espontâneos eram descritos neste contato entre a raiz perceptiva e a fotografia. As imagens fotográficas foram se articulando às representações reais por serem constituídas por informação que integrava estas qualidades perceptivas. A linguagem da fotografia trouxe outra camada, ao existir um espaço entre o olho e a câmera que chamei de transparência, como uma membrana que os dividia. Por esta razão, surge a qualidade característica da transparência atribuída às fotografias, de elas coexistirem neste lugar sensível. 
Mesmo com o caráter fenomenológico das experiências, que elevavam minha percepção e sensibilização do olhar como gesto artístico, a linguagem fotográfica tem uma objetividade pressuposta pelo enquadramento, um contato da luz com uma superfície fotossensível dada pela câmera. Apesar de o foco não estar na objetividade da técnica fotográfica, o enquadramento estava sempre presente na perspectiva de equalização criativa. A luz existia em diferentes processos óticos através das janelas gêmeas. Aos poucos, foi possível identificar a correlação entre os dois processos: a janela física definia uma perspectiva e a câmera outro enquadramento, outra janela. Desta interatividade olhar-máquina surgia o instante do gesto. Difícil definir o que se construía primeiro, às vezes era a luz que comandava através da muxarabi invisível, e eu agia sobre ela; noutras, o meu olhar atravessava a janela para ver a luz. As janelas, por suas aberturas, podem ser vistas como recortes por suas bordas.

Neste sentido, se torna significativa a observação de Roland Barthes em seu clássico livro sobre fotografia, em que destaca um diálogo de Janouch e Kafka ${ }^{30}$ :

'A condição prévia para a imagem é a visão' dizia Janouch a Kafka. E Kafka sorria e respondia: 'Fotografias são feitas para expulsá-las do espírito. Minhas histórias são uma maneira de fechar os olhos'. Barthes acrescenta: [...] A fotografia deve ser silenciosa (há fotos tonitruantes, não gosto delas): não se trata de

${ }^{30}$ BARTHES, 1984, p. 84 
uma questão de discrição, mas de música. A subjetividade só é atingida em um estado, um esforço de silêncio (fechar os olhos é fazer a imagem falar no silêncio).

Ao refletir sobre sua atração pela fotografia, Barthes nomeou dois elementos punctum e studium, cuja co-presença fazia com que ele estabelecesse um interesse pela imagem. "O studium diz respeito ao gosto, interesse adquirido e relacionado à cultura e ao saber, àquilo que me agrada, um meio querer que engloba características ligadas ao contexto cultural e técnico da imagem; já o punctum é aquilo que me punge (mas também me mortifica, me fere)"31. Para Barthes o punctum é o acaso, tem caráter subjetivo, e é um interesse que se impõe a quem olha a foto, diz respeito a detalhes que tocam emocionalmente o espectador e variam de pessoa para pessoa. É o que instiga na foto, a intervenção pessoal e subjetiva do observador.

Nestas experiências, a ação vinha de um estado imersivo, um pacto de silêncio solitário e meditativo que assumo como operação metodológica em todas as práticas artísticas para estabelecer um campo sensível de atuação. As flores do jardim de luz eram imagens habitáveis por mim e, numa analogia com os elementos de Barthes, o studium e o punctum, percebo-os presentes ao assumir dois papéis, do fotógrafo e do observador. As imagens destas composições surgem na aura, e não se referem a um mundo

\footnotetext{
${ }^{31}$ Idem, p. 46
} 
objetivado e sim a um espaço entre o visível e o invisível; talvez aqui o punctum, é o detalhe, o sensível da imagem.

As descrições das práticas seguem no sentido de abarcar a complexidade contida no nascer destas imagens e no conhecimento sensível transmitido por elas. Elas são testemunhos da veracidade da ação artística, portanto carregam uma trajetória de acontecimentos, percepções, emoções, memórias e abstrações. Dar nomes às séries fotográficas foi uma maneira de transformá-las em palavras esta intervenção subjetiva.

Os registros foram, inicialmente, uma necessidade de estabelecer contato corporal e físico de correspondência com esta ambiguidade entre o exterior e o interior. De fato, a fotografia aqui como linguagem foi uma forma de recodificar a experiência, um diálogo entre arte e tecnologia como forma de atualização da poética vivida nas janelas que exigiu a assimilação das qualidades e potencialidades desta linguagem. Com o tempo, adquiri um conhecimento mais objetivo sobre a operação da câmera. e passou a existir uma intencionalidade no entrelaçamento entre as linguagens - criar com luz e criar na luz. As fotografias passaram a ser uma escritura documental do meu processo experimental de examinar o sensível das imagens através da luz e uma nova materialidade do imaginário.

Apesar de não ter profundo conhecimento sobre a arte da fotografia, com o conhecimento sensível sobre a luz adquirido anteriormente, ao longo da minha práxis cênica como iluminadora, pude ver pontos de intersecção com esta arte, e outras perspectivas de criar com a luz. 
As séries: Tem luz em Sampa, Lâmpada de sol, Transparências, são testemunhas nascidas deste processo e compõem meu repertório de experiências artísticas dadas por qualidades perceptivas e relações de tempo e lugar numa convivência mútua e criativa de restabelecer ao espaço uma qualidade do sensivel que vive em mim.

A intervenção digital se apresentou como uma nova poética: dar forma a outra forma, criar outras camadas da imagem. A manipulação por meios digitais desvendam outras possibilidades estéticas e uma recodificação da experiência vivida, ampliando o campo sensível do criador. Outro jogo para a percepção, uma nova relação espaçotemporal. Neste sentido, a tecnologia empresta suas qualidades para a recriação de novas imagens. Isto gerou um diferente ato de criar desvinculado de prática analógica, uma liberdade de inventar novos espaços para a experiência. 
A Série Tem Luz em Sampa ressignificou meu olhar através da dupla perspectiva, ocupando um lugar de sobrevivência, preenchimento e memórias de referências luminosas significativas para a relação que estabeleci com a cidade de São Paulo. Posteriormente, levei essa relação orgânica para a prática docente, como exercício de sensibilização do olhar. Contemplar a luz da cidade de São Paulo durante as quatro estações a partir de uma mesma posição, em diferentes horários, ativou minha percepção sobre a manifestação da luz natural na cidade, suas colorações, seus prédios, seus ruídos e minha comunicação com isso. Numa ação que pode parecer monótona e repetitiva, ao olhar sempre a mesma paisagem, penso que olhar é se colocar sempre na perspectiva de estar em algum lugar, um campo de presença sensível aberto a possibilidades perceptivas que revelam o espaço. O fenômeno luz é uma comprovação de que a imagem pertence ao olhar, podendo ser descrita de diferentes formas. A experiência com a luz nunca é igual, e isso a torna complexa. As ocorrentes mudanças na paisagem frente à sensação de cor, luminosidade, atmosfera, clima e sua trajetória ao refletir na matéria criam infinitas imagens, e a perspectiva da luz sobre a retina pode ser alterada a todo momento. Quem define isto somos nós. Podemos ver muito se nos propusermos a tal.

Durante esta ação, refleti muito sobre conceitos e práticas da arte da iluminação cênica, como ângulo, cor, movimento, atmosfera, ritmo e intensidade. Tudo estava lá, nas janelas. Ao observar e registrar a interferência da luz num único refletor que se movia 
naquele fragmento da cidade, modificava-se minha percepção sobre a paisagem, seus detalhes, formas, sutilezas e movimentos. Aos poucos, fui me conscientizando da questão fisiológica da minha própria visão através da câmera e do diafragma. Manipulava a forma de ver através dos ângulos e escolhas, e muitos efeitos apareciam espontaneamente. Ao mesmo tempo, captava o que via e o que sentia. Tudo era simultâneo, não havia lugar para pensar, apenas reagir aos impulsos emitidos pelas matérias compostas pela luz. Uma busca junto aos contrastes e justaposições nas relações luz-espaço-paisagem. São radiações, ritmos, cores, frequências e sensações que transfiguram as formas e nos mostram a matéria em diferentes perspectivas. Ainda que a paisagem fosse sempre a mesma, a cada dia eu era confrontada por diferentes e variadas situações; surgiam espaços e formas ainda não vistos, nada se repetia, para a luz não existe constância nem permanência ao olhar, aí vive o desafio da percepção. Ela vive além dos olhos e, para mim, era possível ver frações de imagens, como um recorte microscópico do fenômeno.

Volto a Coccia, quando afirma que o sensível não existe dentro da matéria, mas sobre ela. Para ele, quanto à natureza das imagens, elas não vivem no mundo físico e nem no espaço do conhecimento do sujeito, e sim num terceiro espaço metafísico, que é seu espaço próprio ${ }^{32}$. Em alguns momentos de contemplação das manifestações da luz na natureza, percebo presente este estado metafísico. Gosto de atribuir o termo alquimia às experiências com luz, em razão da transmutação da matéria. A luz é uma radiação com

${ }^{32}$ COCCIA. Física do Sensível: pensar a imagem na Idade Média. In: ALLOA, 2017, p.85. 
muitas facetas, apesar de não ser palpável; onde ela toca, algo se modifica. Antonin Artaud, em seu Teatro Duplo ${ }^{33}$, atribuiu ao teatro o princípio alquímico, como uma misteriosa identidade que evoca os símbolos alquímicos. Para ele, a alquimia portava uma identidade análoga ao teatro no aspecto de transcendência, ao evocar a transfusão ardente e decisiva da matéria pelo espírito. As experiências perceptivas da luz muitas vezes acolhem estas formas invisíveis no lugar e visíveis dentro de nós.

O jardim de luz, hoje, me ajuda a pensar sobre a prática metodológica de sensibilização do olhar na formação de profissionais que adotam a luz como objeto artístico e de composição da imagem. Como docente, proponho exercícios práticos experimentais para que os alunos se conscientizem de seus processos construtivos de visualidade através da observação dos fenômenos óticos na incidência da luz natural. Para identificar a percepção do espaço iluminado, costumo perguntar-lhes qual a cor da sua cidade natal. É interessante pensar que parte da construção de nossas referências luminosas provém da nossa experiência corporal e perceptiva com o lugar em que vivemos. Cada localidade possui características específicas conforme sua localização geográfica, vegetação e construções. Sou natural do sul do Brasil, da cidade de Porto Alegre, uma cidade banhada por um rio, o Guaíba. A cidade tem como cartão postal

\footnotetext{
${ }^{33}$ Antonin Artaud abandona definitivamente o teatro e o cinema para se lançar a sua grande obra exterior (O Teatro e seu Duplo, Van Gogh, Pra Acabar). Em Teatro e seu Duplo estão colocadas as bases de seu programa para uma existência poética e uma poética existencial, a única que faz sentido. Publicado em 938, o livro é composto por vários textos escritos entre 1931 e 1936.(COELHO, 1982, pp.79-80)
} 
turístico seu pôr do sol no rio. Na orla, tem uma vegetação de plátanos, árvores com folhas grandes e bem desenhadas. No outono, as folhas secam e adquirem uma coloração cobre e textura polida. Trago na memória a referência luminosa dessa estação como a cor da minha cidade. No outono, ao final da tarde, a luz adquire uma tonalidade âmbar que nunca vi em outro lugar. Acredito que a incidência da luz sobre as folhas cobreadas dos plátanos e refletidas no rio nos dá esta sensação de cor. Se pensarmos que onde a luz incide algo acontece, no outono ela se manifesta assim numa Porto Alegre pigmentada, na linguagem de uma iluminadora, de um filtro cromático âmbar 22, refletindo um espectro de comprimentos de ondas mais avermelhados. Habitualmente, ao me apresentar aos alunos, compartilho essa referência associada à minha procedência e memória da cidade natal como forma de aproximação pela experiência de luz. Com o tempo, o deslocamento por diferentes lugares sendo parte da minha rotina profissional, fui exercitando as percepções sobre regiões diversas através da cor e da fisicalidade da luz - um permanente exercício de sensibilização do olhar. A natureza é o laboratório mais perfeito e rico para compreensão das relações cor-luz e cor-pigmento, é destas experiências perceptivas que se alimenta nosso repertório de imagens de luz. Dentre meus deslocamentos no Brasil, a oportunidade de conhecer a floresta amazônica, o sertão nordestino, o pantanal, a região litorânea, os pampas e serras sulinas reafirma meu pensamento sobre a dimensão da luz na sua fisicalidade, poética e simbologia, e sua forte relação com a arte ambiental. 
Nos cursos que ministro na cidade de São Paulo ao formular a pergunta sobre a cor da luz da cidade natal, a maioria dos alunos paulistanos responde cinza. Como podemos ver, tudo é relativo, cor não existe, ela é mera sensação visual criada por nós. Apesar de a questão parecer simples, a resposta é complexa, pois está ligada a muitas percepções, não somente da luz, mas da matéria, da atmosfera, do comportamento, das sensações, além da própria cultura e da experiência de cada um com o corpo e o espaço.

Na minha necessidade de ar, migrante sulina recém-instalada em um apartamento com duas janelas e um jardim anexo, vi cor e descobri Tem Luz em Sampa, e ela é linda. 

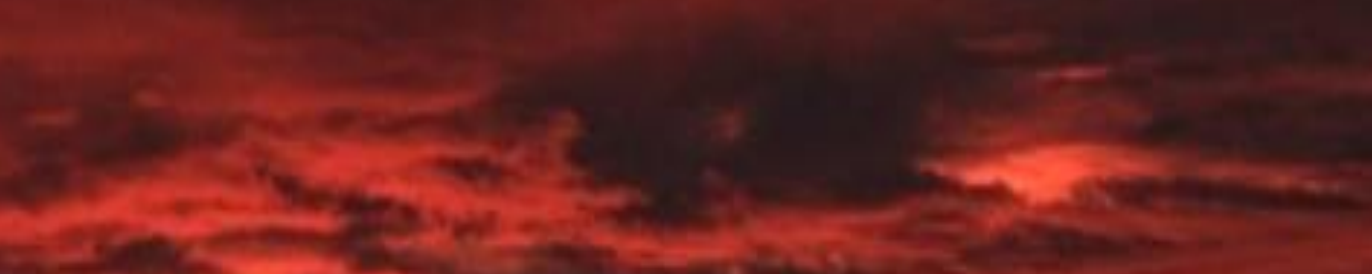

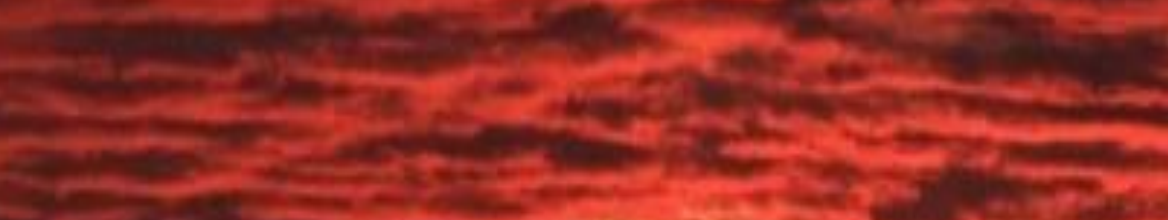

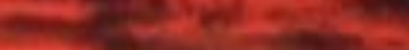

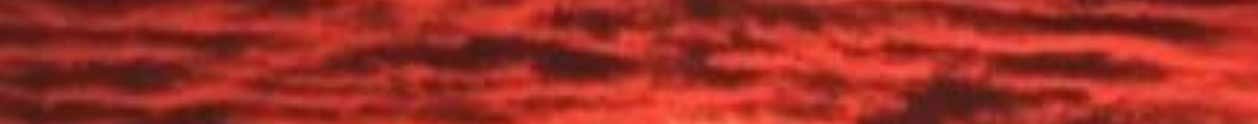

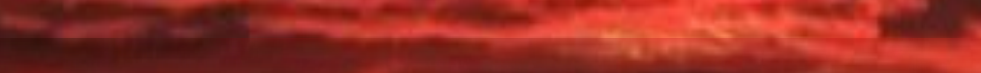

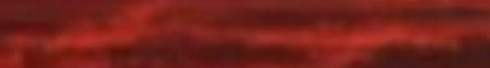

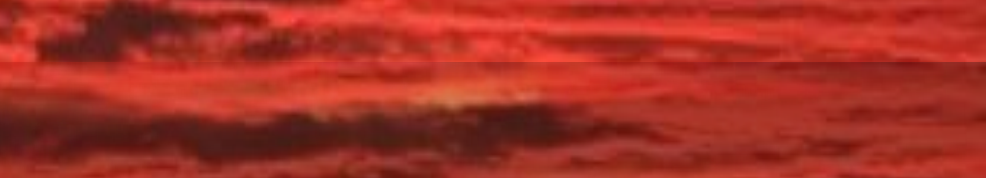

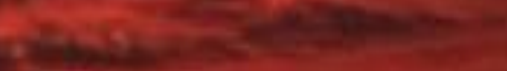



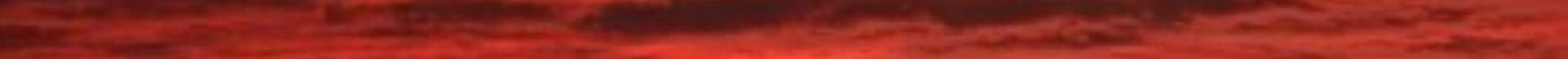

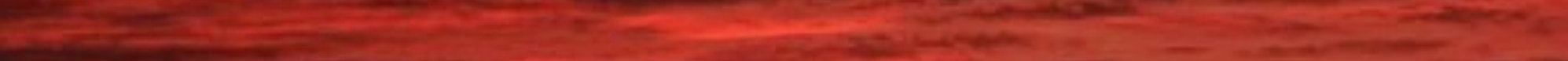
L

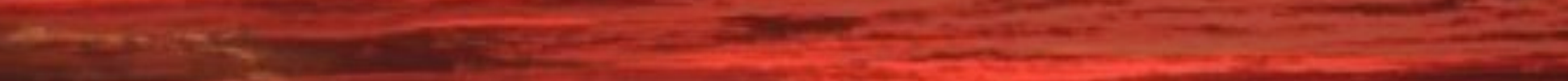

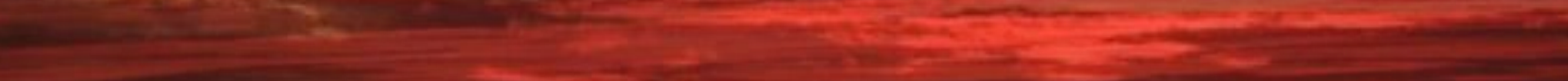

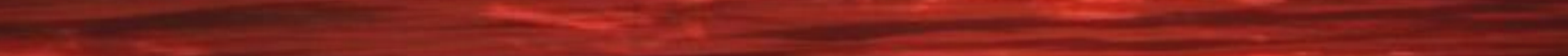

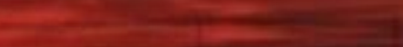
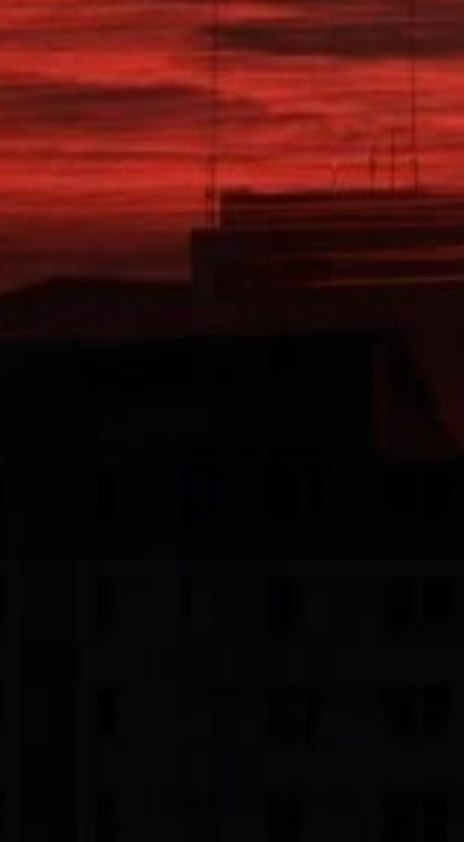


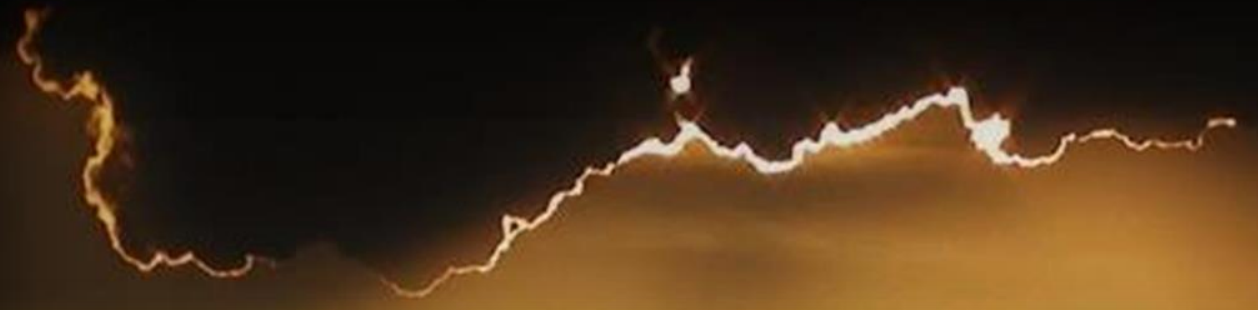

7
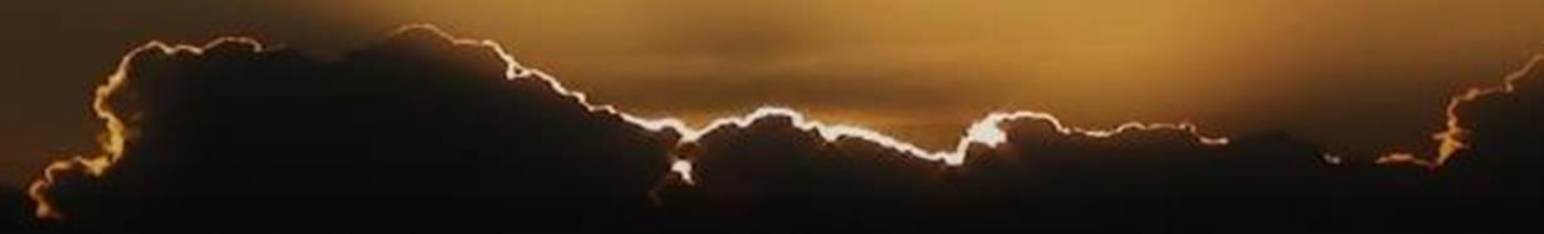




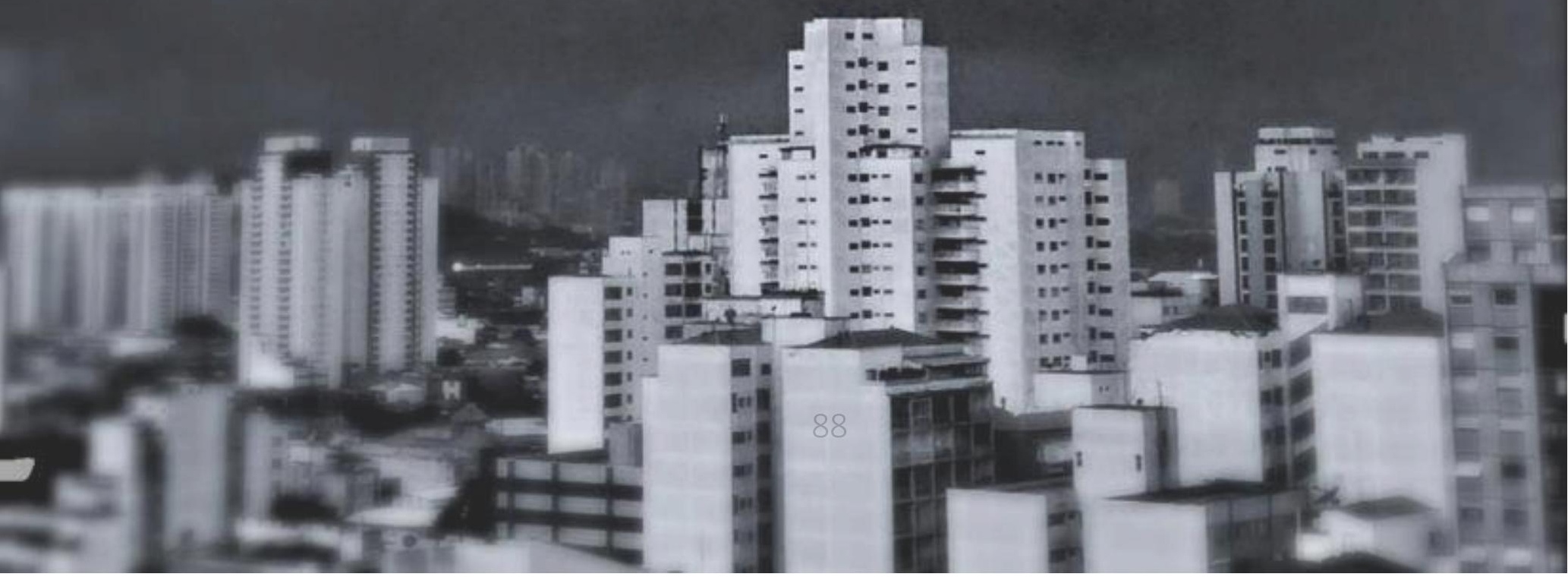




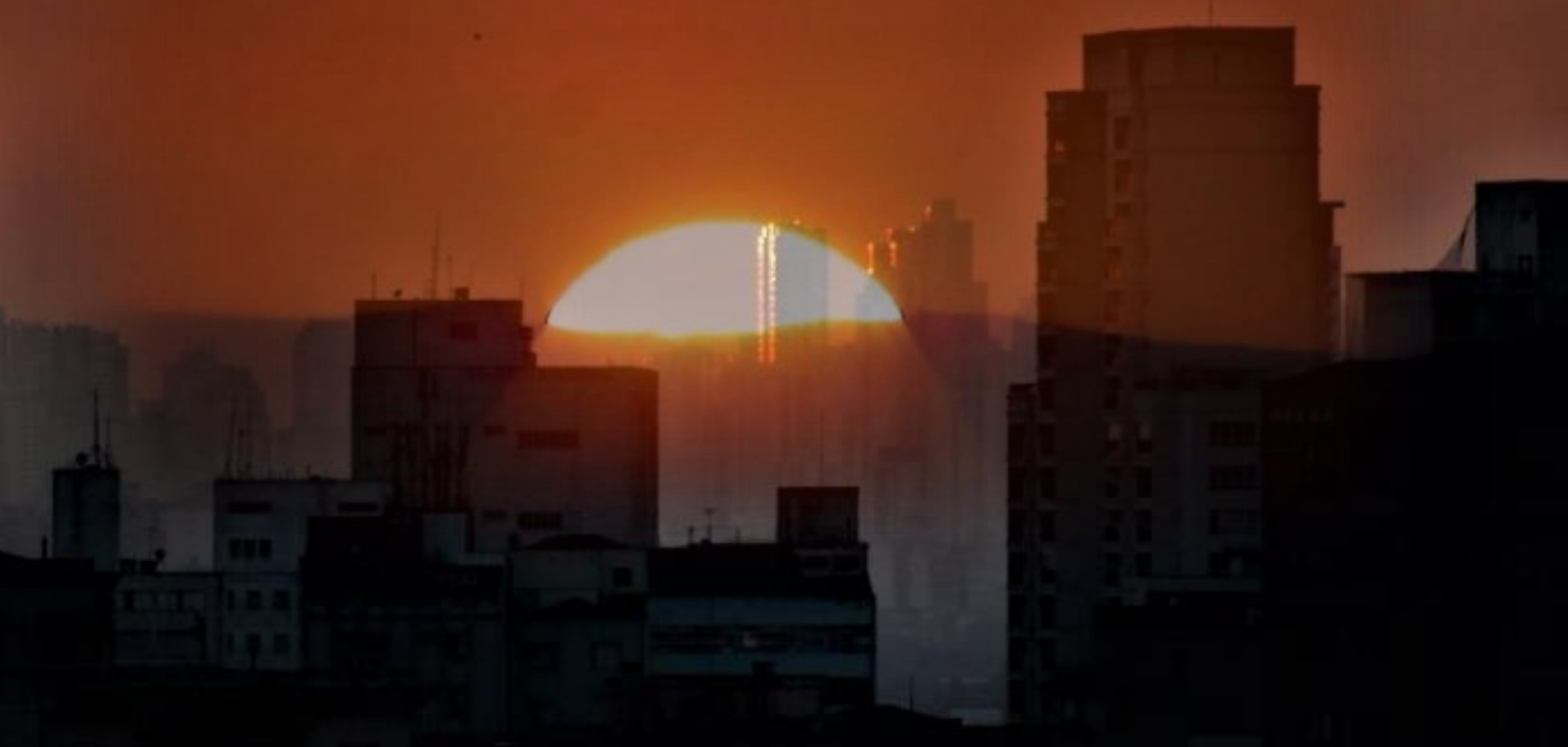


in: 


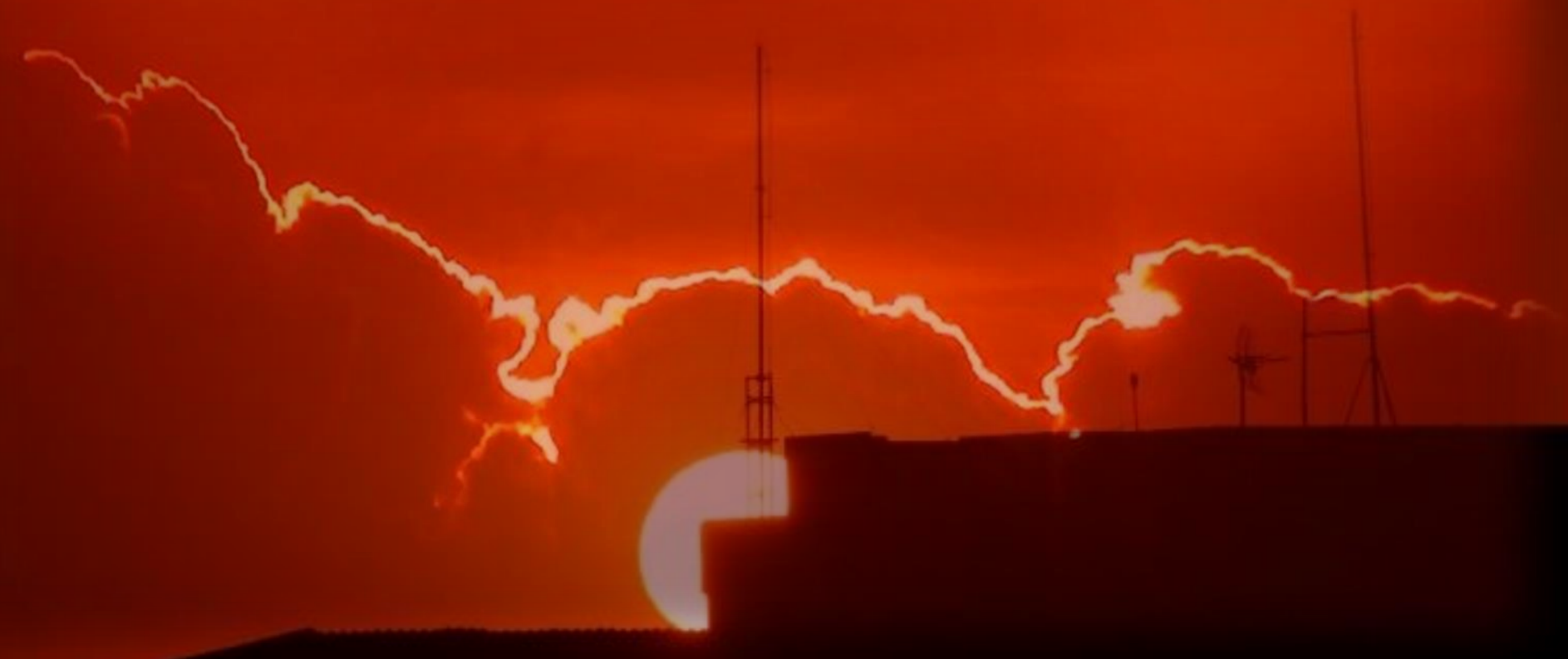




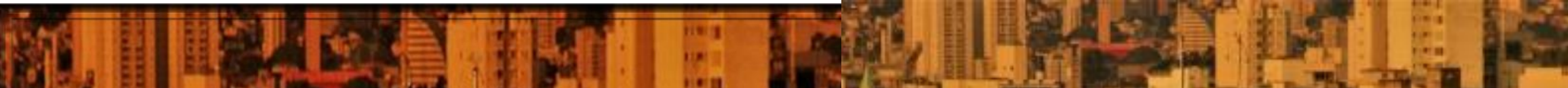

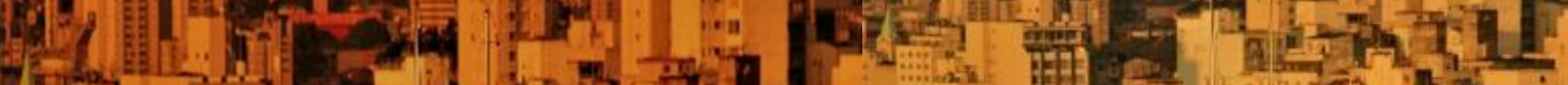

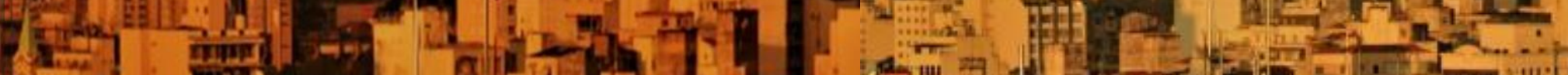


"irr

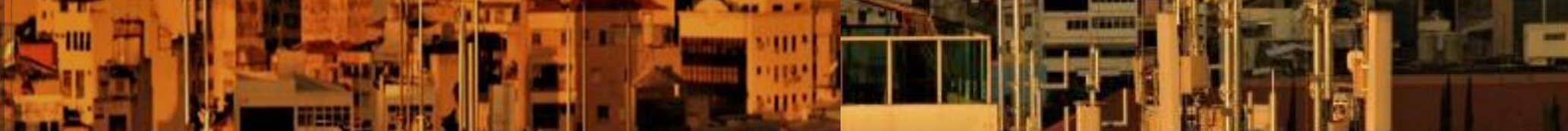

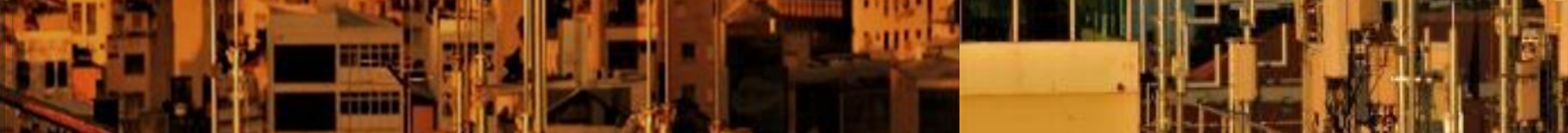

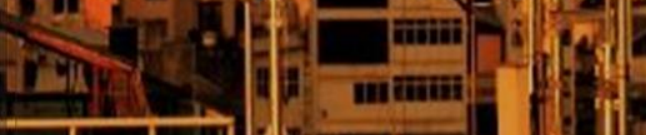

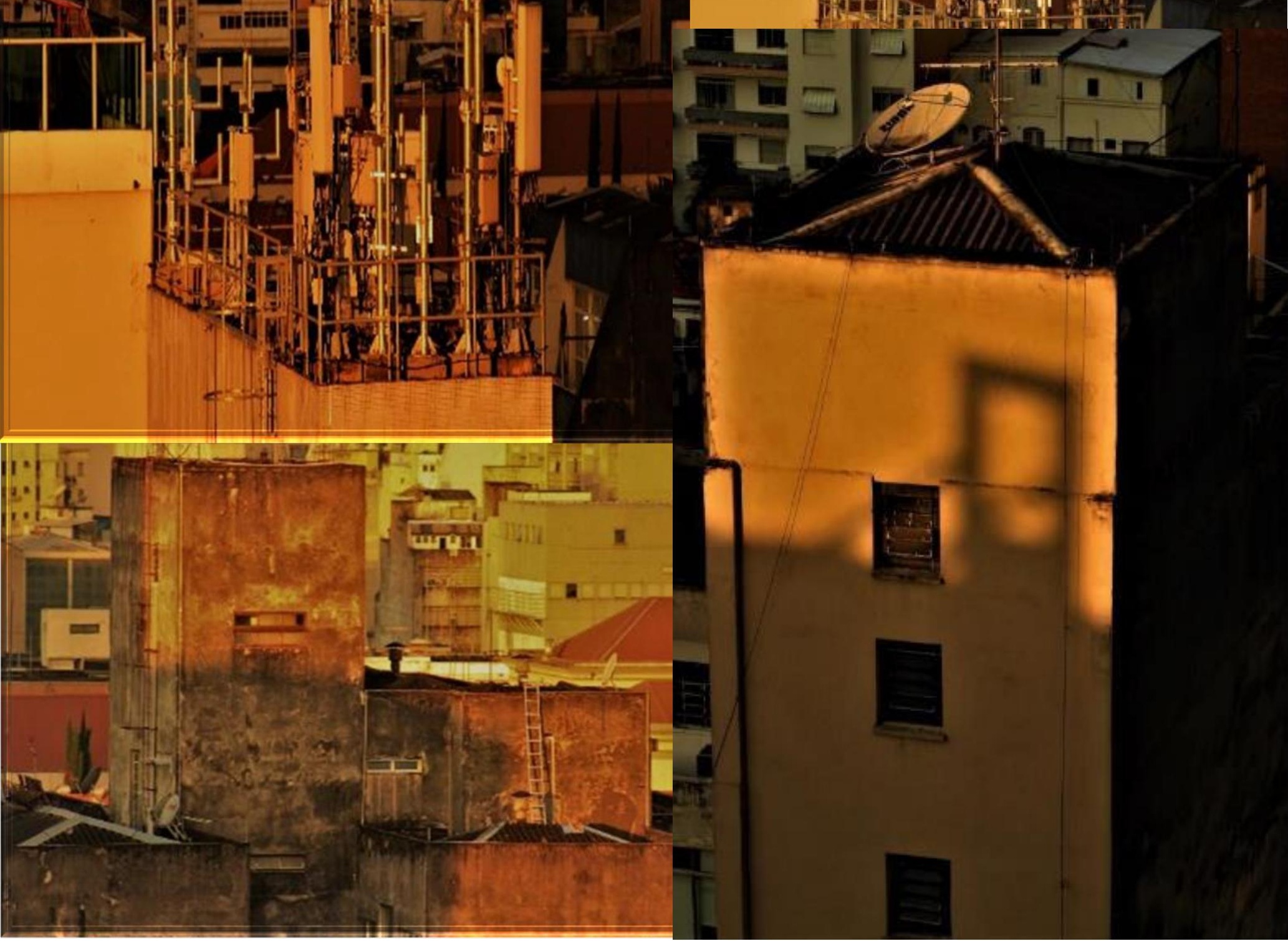




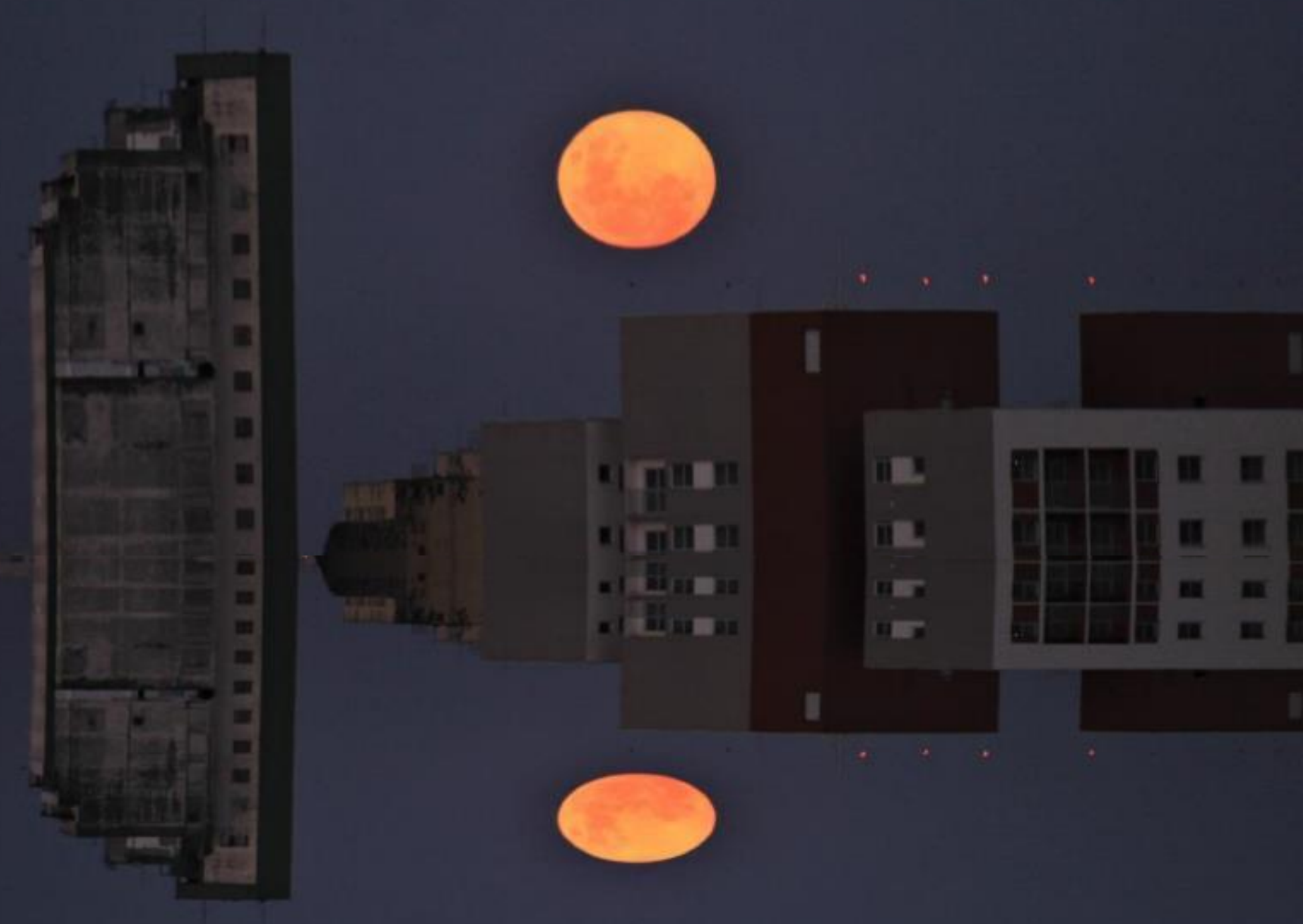



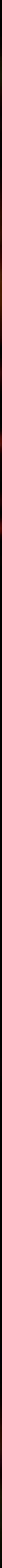
Lâmpada do Sol

A imagem fotográfica é sempre mais que uma imagem: é o lugar de descarte, de um fragmento sublime entre o sensivel e o inteligível, entre a cópia e a realidade, entre a lembrança e a esperança.

- AGAMBEN, 2007, p.29 
O argumento gerador é, novamente, a memória de uma referência de luz. Sou de uma geração em que as casas eram iluminadas por lâmpada incandescente, e o que definia a luminosidade era a potência destas lâmpadas, não a qualidade da energia luminosa. Mais watts significavam mais iluminância e mais luminância, ou seja, mais luz no ambiente e nos nossos olhos.

Falo em resgate da memória por perceber que a retirada das lâmpadas de filamento do mercado e sua substituição por outros artefatos luminosos nos distanciam cada vez mais das referências da luz natural. A necessidade mundial de redução de consumo energético fez proliferar alternativas de iluminação artificial, desconsiderando fatores relevantes que essas radiações luminosas podem causar à saúde. A invasão dos LEDs, diodos emissores de luz, a meu ver repercute numa mudança de paradigmas da iluminação artificial. O mercado econômico é bem mais acelerado e voraz que o processo de adaptação do nosso olhar. Não nos damos conta do quanto isto nos contamina e nos distancia da natureza. A lâmpada incandescente de Thomas Edison aqueceu e iluminou por muitos anos nossas casas e cidades. Por ter sua curva espectral muito próxima à do sol, nunca nos preocupamos com isso, pois víamos o mundo como ele era, sem duvidar das cores nem tanta necessidade de alta luminosidade.

A luz na sua representação mais genuína deixa de ser uma complementação dos nossos espaços. Creio aí estar um dos paradoxos que envolvem a luz e a iluminação. Percebo 
que os conceitos ligados à iluminação, visibilidade e saúde tomam caminhos distintos da essência da luz, a ponto de não sabermos distinguir nossas necessidades luminosas.

Ao mesmo tempo, vivemos num mundo iluminado e ofuscante com nossos dispositivos tecnológicos, computadores e celulares que agridem nossa visão de maneira tremenda. Pouco percebemos as diferenças de qualidade luminosa vinda de outras fontes e dos LEDs, e longe de serem lâmpadas, emitem radiações brilhantes que, sem regras de utilização e aplicação afetam nossa saúde, alterando nosso sistema circadiano e repercutindo em muitas doenças. Estamos absorvidos por uma luminosidade tóxica que nos afasta do mundo natural, e nossas referências de cor mudam a cada dia, modificando nossa visão e sensibilidade à realidade material. O que vemos é o que queremos realmente ver? Paradigmas deste século. Nesta bolha luminosa, mergulhamos num buraco que inevitavelmente vai nos levar a representações distorcidas do mundo real e natural. Assim também se dá com a proliferação de imagens que nos invadem, e já nem sabemos dizer ao que correspondem; criam vieses inconscientes que refletem em ambientes distantes de nossas reais necessidades.

Ver o sol dentro da lâmpada resgatava esta memória da incandescência e da luz natural, suas similaridades, seus espectros e esse tempo em que éramos regulados pelos ciclos circadianos e era a luz que nos avisava a hora de dormir e de despertar. A instalação era composta de uma lâmpada de bulbo E30 com filamento incandescente, um adaptador com rosca E30 e uma extensão elétrica de 3m, suspensa na parte superior da janela. 
De manhã ela permitia acender a cidade, estabelecendo contato entre luz, lâmpada e cidade, um despertar poético, daí o nome lâmpada de sol. Havia uma interatividade com a instalação, pois eu manipulava o ângulo e o que eu queria ver dentro da lâmpada.

A lâmpada de sol inspira a poesia da luz solar e, ao mesmo tempo, remete ao abismo que estamos criando para esta referência. A instalação tinha uma inversão entre roubar a luz para dentro do bulbo e um faz-de-conta de trazer a cidade para a luz. Ela transformava o lugar com tais metamorfoses, como uma lâmpada mágica em que o sol era o gênio da lâmpada e cuidava de acendê-la.

Para mim, as imagens construídas desta poética refletem a transparência do espaço que existia entre o bulbo, a cidade e a luz. Hoje, por mais simples que sejam, elas portam uma latência e potência. 



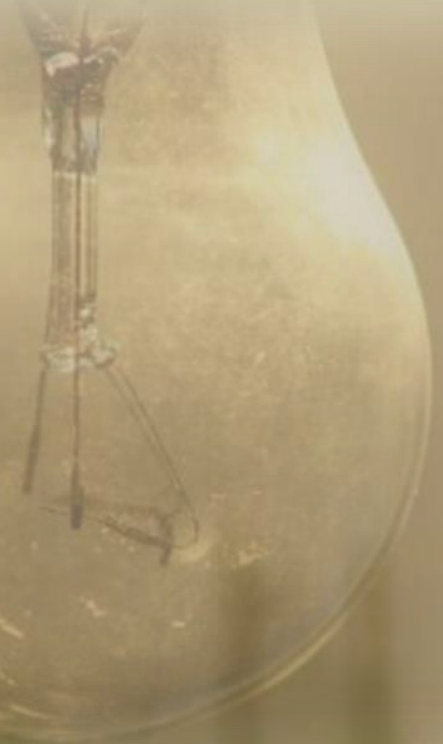





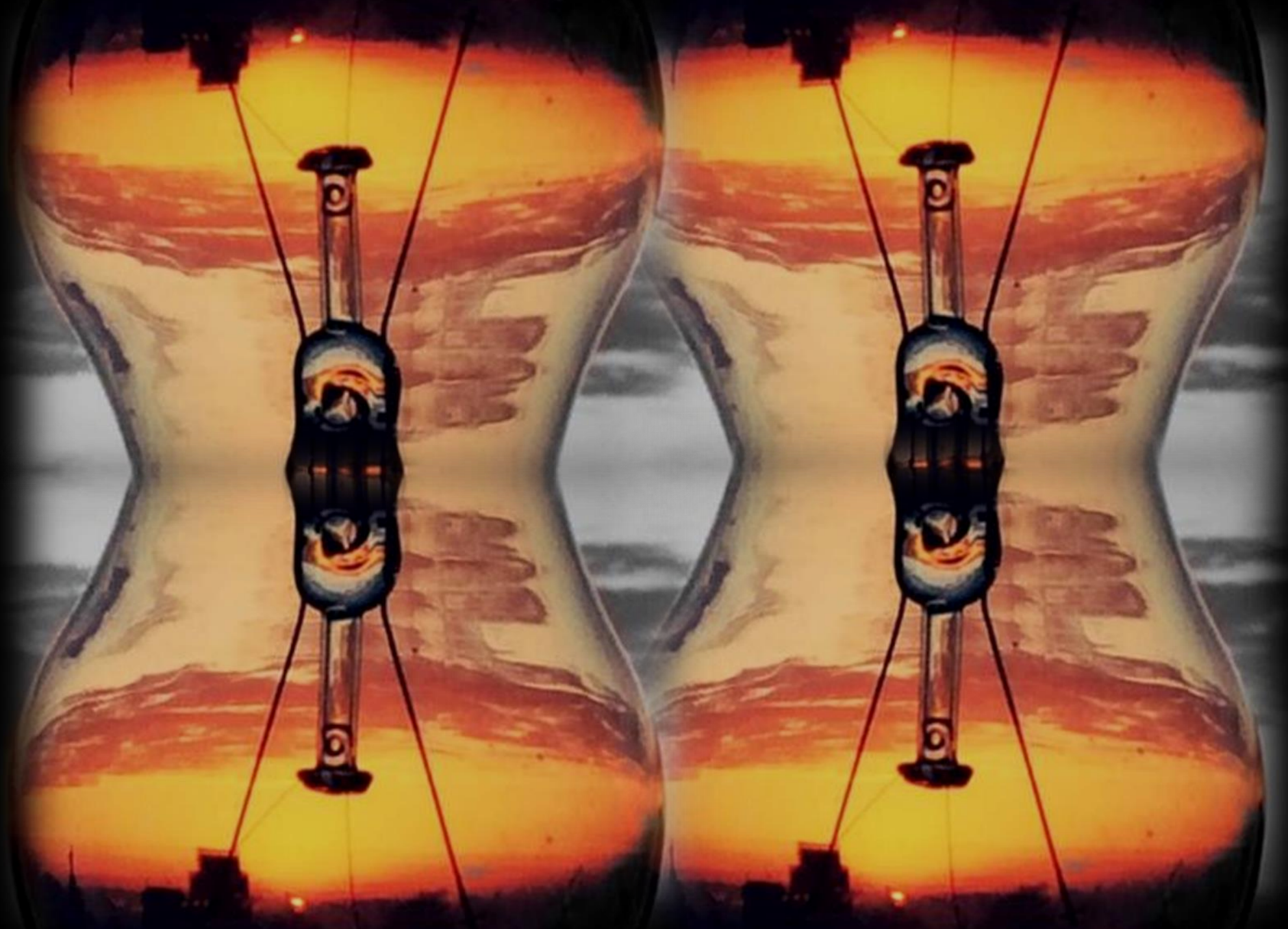









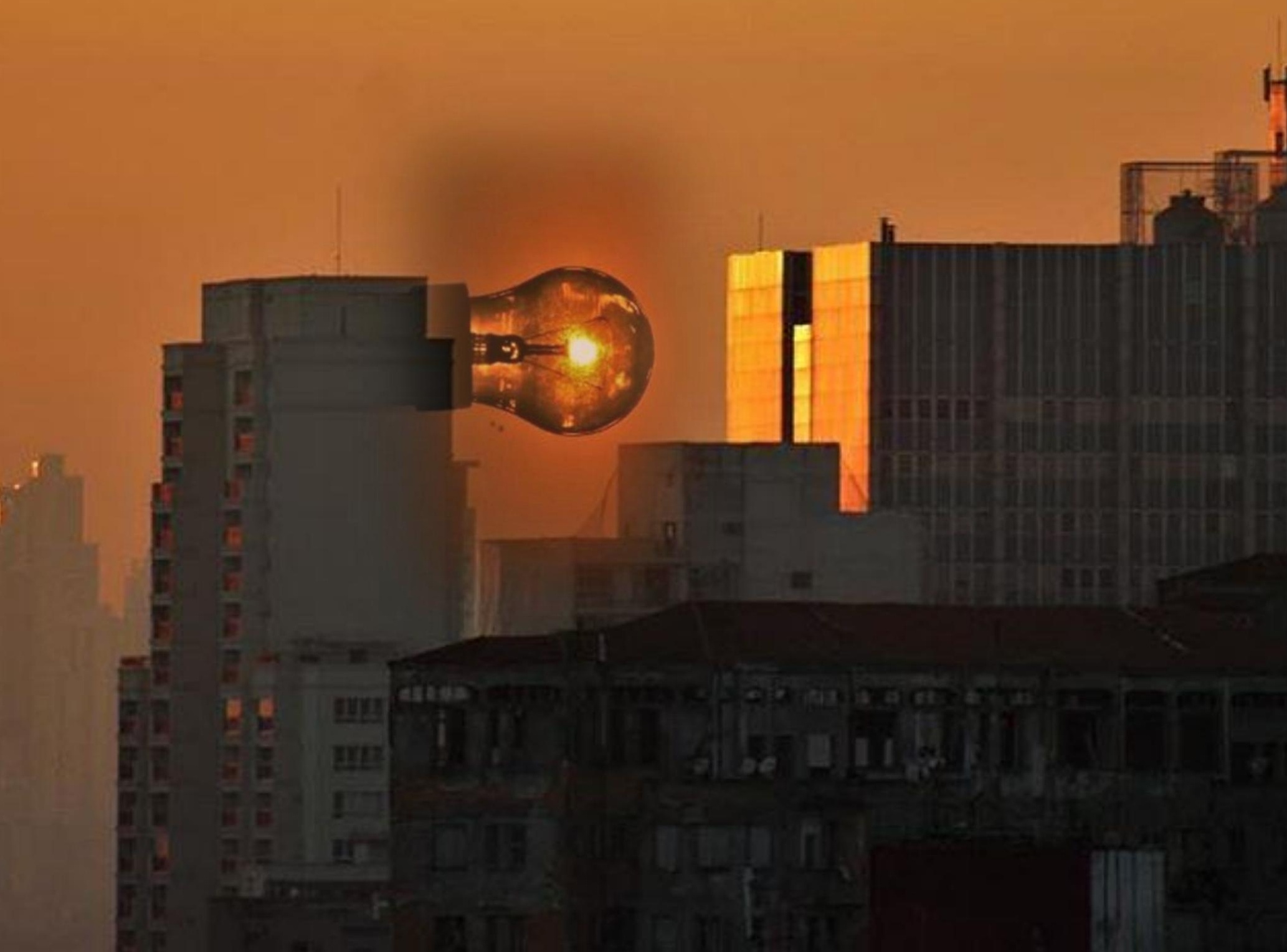




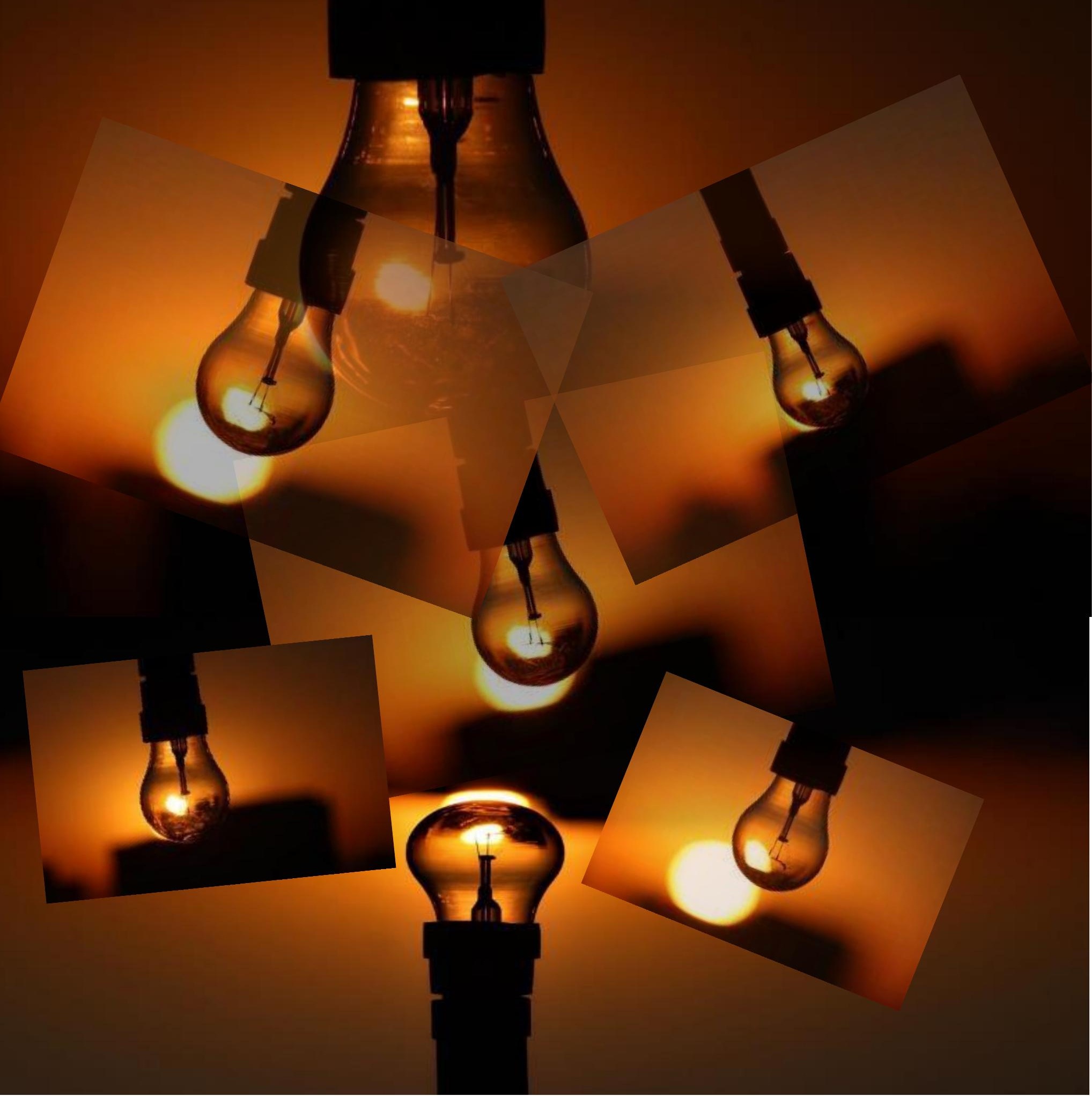




\section{Transparências}

A fotografia é uma porção pequena do espaço, bem como do tempo.

- Susan Sontag 
Transparências são divagações imagéticas sobre o tempo não cronológico, a espera, o vazio, aquilo que transpassa alguma fresta. As janelas são limiares em que a experiência se conecta e diferencia. São filtros que se localizam no entre as imagens. A poética se apresenta naturalmente por traduzir algumas reflexões criativas da luz, na medida em que interage com materiais translúcidos e polidos como vidros, cristais e água, afetados pelo fenômeno da difração e reflexão. Esta série reflete as intersecções entre luz e matéria, em que a bidimensionalidade da fotografia é superada pela tridimensionalidade dos objetos e suas transparências, criando outras possibilidades de composição e formas de rever o sensível da imagem através de novas imagens e construir realidades subjetivas.

Nestas experiências começou a haver uma intencionalidade fotográfica de reproduzir o contato perceptivo da experiência e a correspondência com as instalações. Existia uma plasticidade estética nas narrativas imagéticas. Uma distração para os dias nebulosos, nublados e chuvosos em que agem os difusores naturais. A qualidade da luz é sempre difusa, tem um efeito monocromático e uma temperatura de cor fria, com raras exceções, próprio das transparências. Os objetos que compuseram as instalações foram decisões visuais nesse contexto, translúcidos como a água, o gelo, o vidro. Na construção destas imagens, identifico uma particularidade do meu senso estético e minha relação com a cor. Sou quase monocromática quando penso em cor-luz. Nos desenhos, a utilização de filtros corretivos de temperaturas de cor é mais comum nas minhas escolhas do que os 
pigmentados. O reconhecimento das diferentes temperaturas da cor nas manifestações da luz natural é muito sensível aos meus olhos, e aí já vejo muita cor. Portanto, as opções de pigmentar a cor da luz precisam ser muito pensadas, e por vezes são decisões difíceis para mim. A razão disso provavelmente se deve ao fato de eu não enxergar as coisas tão mais coloridas do que se apresentam. Utilizo a pigmentação na luz numa relação mais simbólica dada pela cor ou como código visual. Quando aprendi sobre a composição física espectral da luz e sua interferência sobre o pigmento da matéria, entendi que a matéria tem, por si só, uma verdade sobre a cor, aquela que vejo. Na arte da iluminação podemos manipular isso, e alterar as sensações de cor das coisas e dos espaços; porém, estas escolhas devem encontrar ressonância no que iluminamos e na imagem construída. Neste contexto, a cor pode representar um código ou mera representação pictórica.

O aspecto subjetivo melancólico, solitário e a minha tendência monocromática se imprimem nestas composições. A série Transparências compunha os buquês do jardim, pois, de certa forma, eram mais elaboradas esteticamente.

Os registros aconteceram espontaneamente, por necessidade de comunicação com a imagem e preenchimento de meus estados subjetivos com os materiais. As janelas se tornaram molduras para as telas que eram pintadas com copos, cristais, gelo, arquitetura dos prédios, ventos, reflexos, nuvens, chuva e sentimentos. Tinham uma pincelada daquilo que assimilo de princípios da Gestalt pela forma como se organizavam. 
As relações do espaço, luz e objeto acompanhavam os fundamentos de linha, forma, contraste e profundidade.

Diferente da prática teatral, em que meu ofício consistia em acompanhar a montagem de luz, aqui eu montava o cenário e dirigia a cena. A luz era o que existia no espaço e comandava o olhar sensível sobre os objetos; a mim cabia o enquadramento deles. A propósito, foi interessante analisar a questão do enquadramento em relação à caixa cênica e ao olhar do espectador. No teatro, o espaço cênico é definido e coisas se relacionam lá dentro, há uma ação e uma cenografia que constituem a visualidade da cena. No cinema também é assim, mas nesse caso, podem ser feitos recortes da imagem e todo objeto é tridimensional, visível por qualquer face. É a imagem que gira ao redor do olho, e no teatro é o olho que gira em torno da imagem. Creio que, ao pensar neste processo, estabeleço uma relação com as duas linguagens. Ao mesmo tempo que as janelas davam um ângulo de abertura para enquadrar a imagem com a luz, existia o recurso do recorte pelo olhar da câmera.

Por fim, 'Transparências' foi o nome que encontrei para preencher a memória do meu corpo nestes encontros físicos, poéticos e filosóficos. 


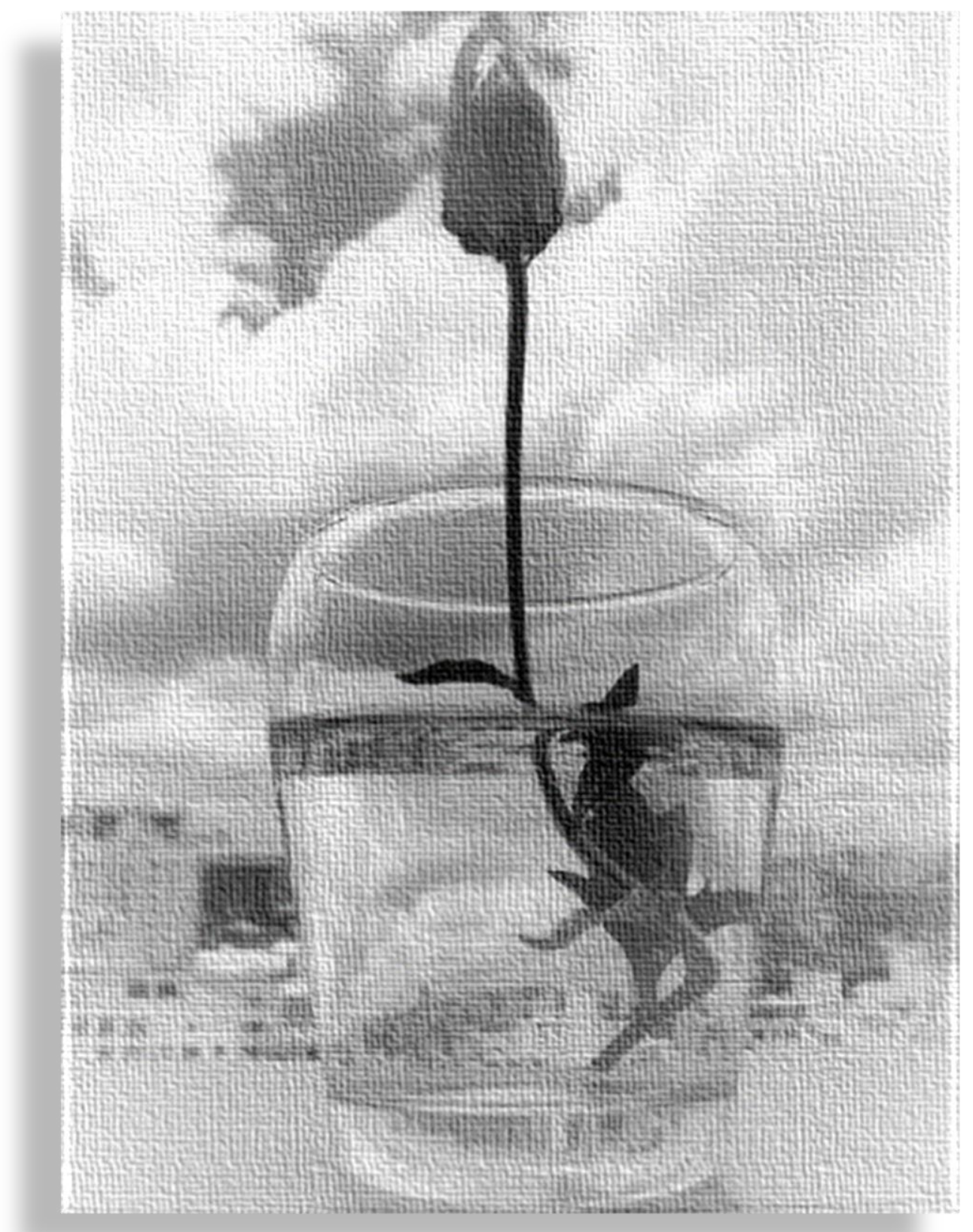

112 

$\therefore$ s $\quad 3^{2}$$$
\because \because \because 3
$$$$
\text { S } 1
$$$$
\because \therefore 1
$$$$
\text { a }
$$$$
\because y^{3}
$$$$
\therefore \therefore
$$$$
4 s^{3}
$$$$
\therefore 9
$$$$
\therefore y
$$$$
\therefore ?
$$

i.

\& $y^{2}+1$



rivi.

viviss.

,

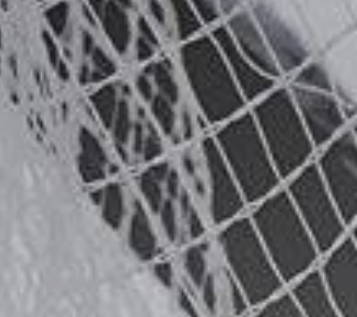




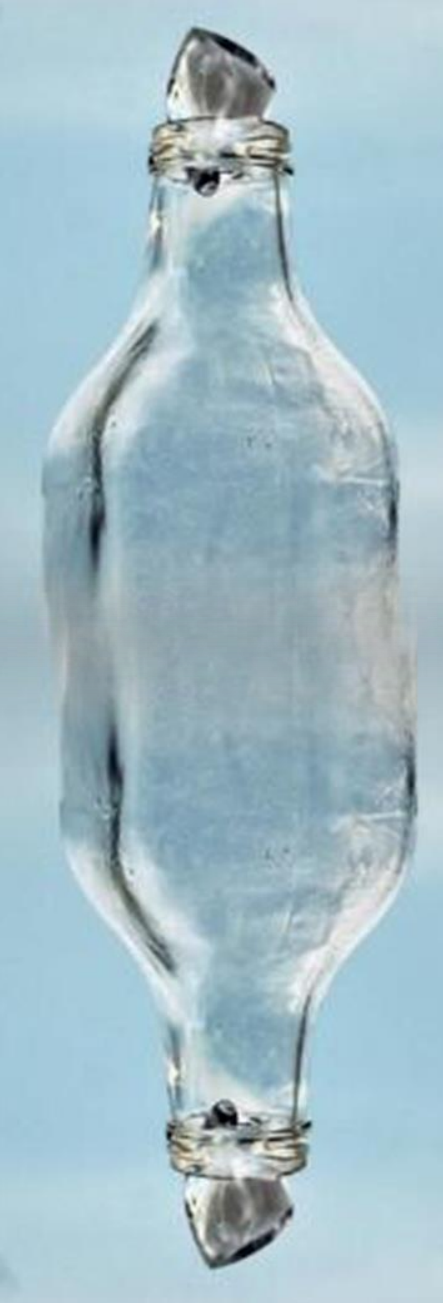




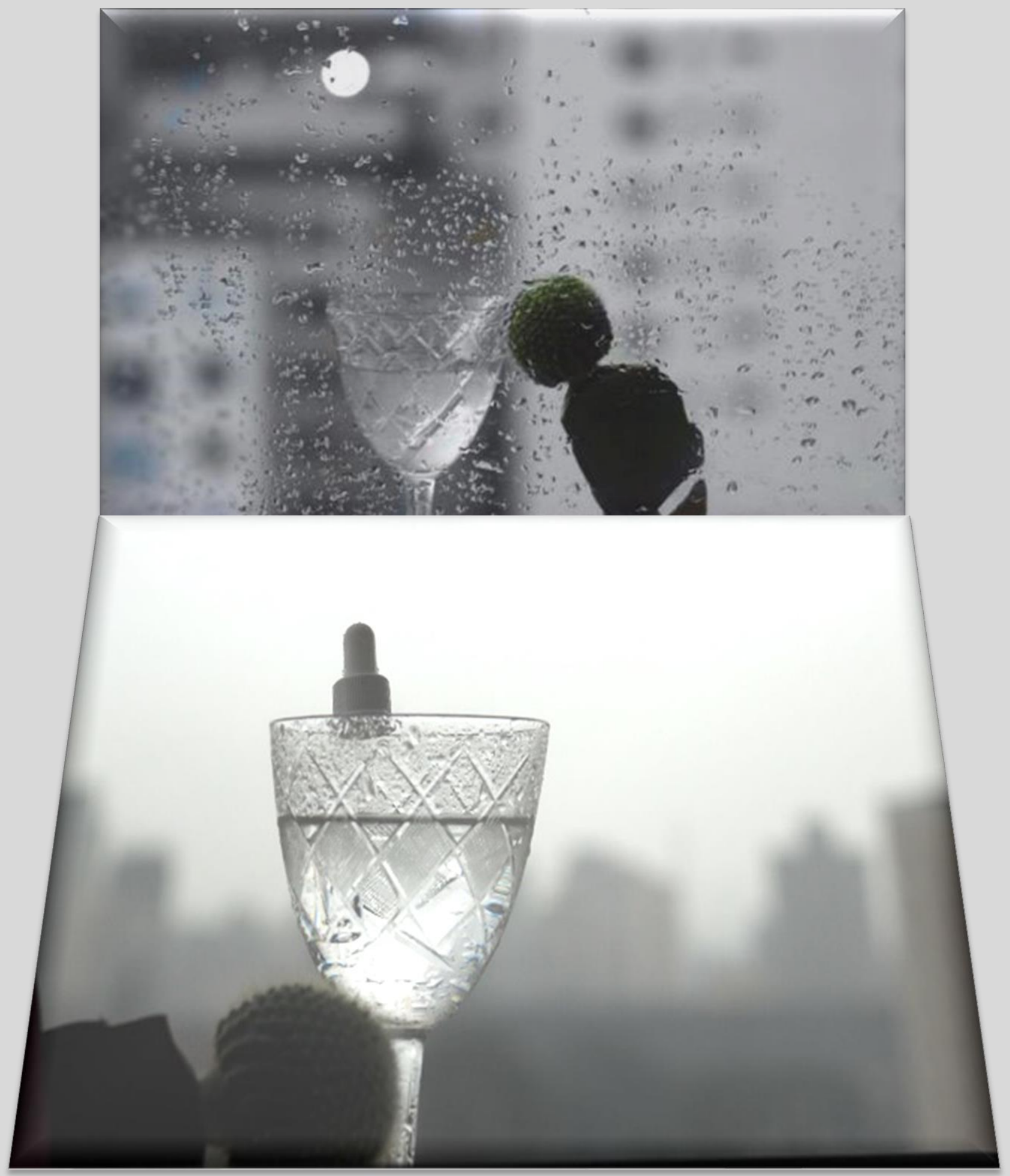








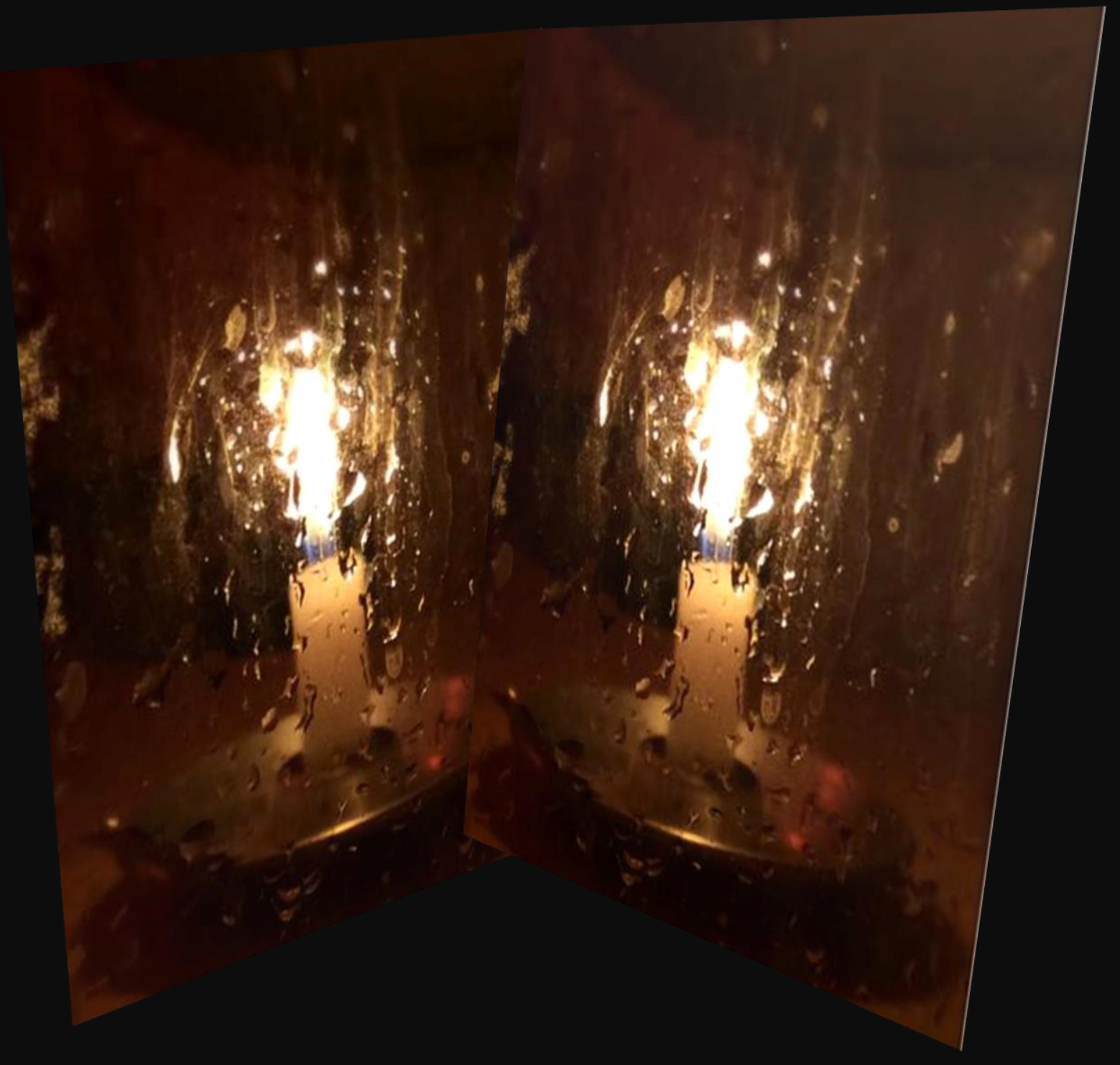




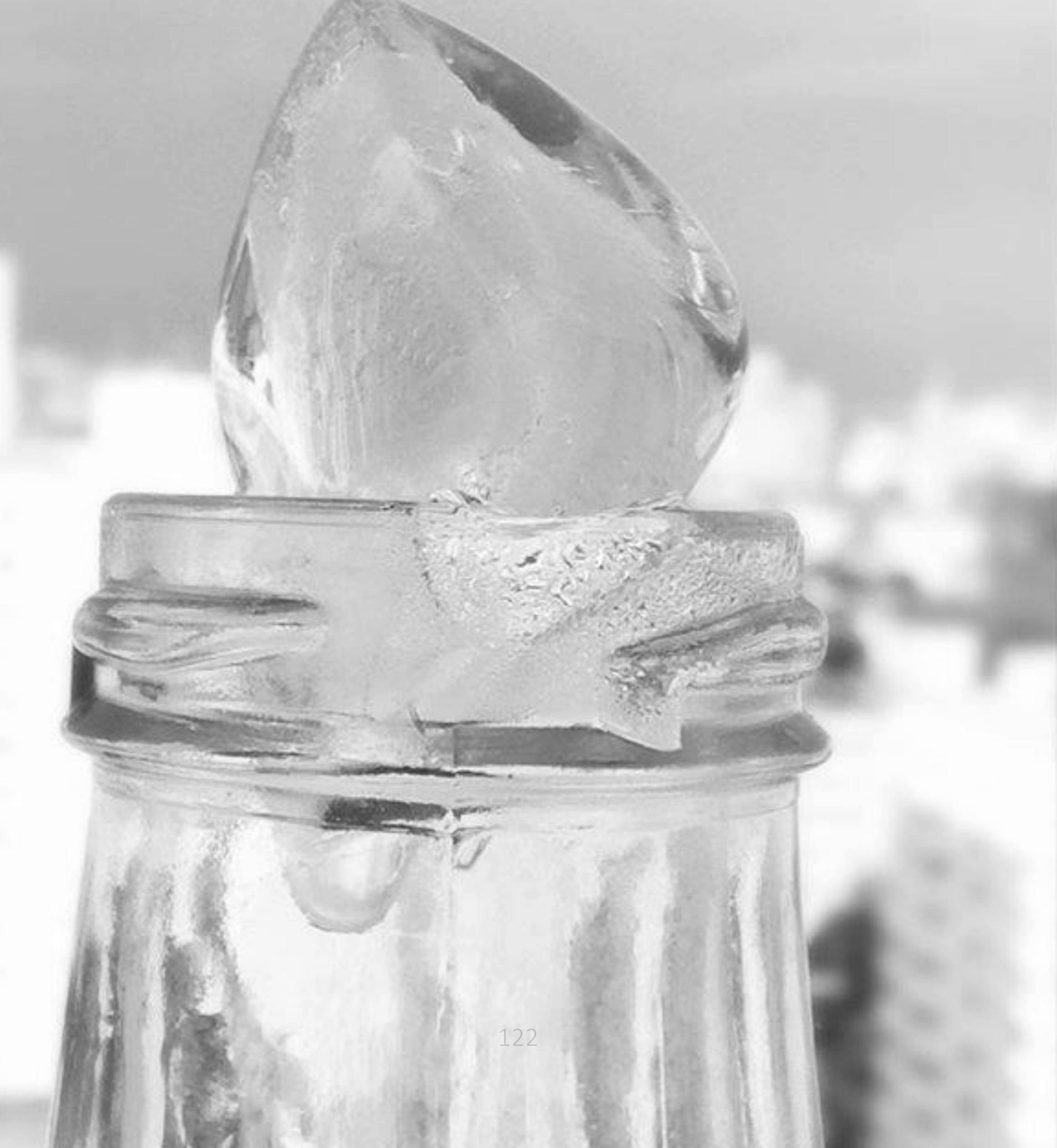





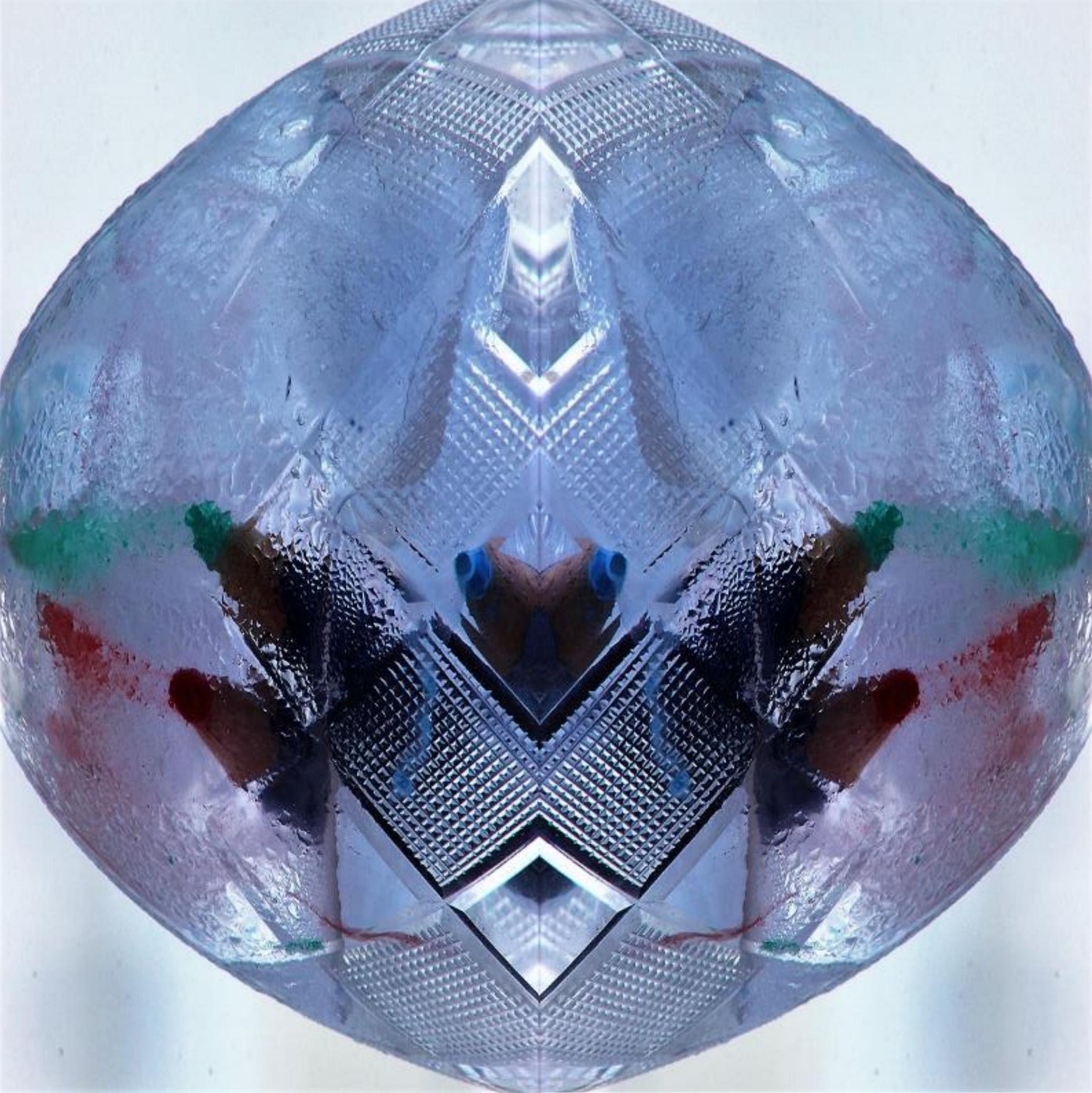






Ao mesmo tempo em que me senti atraída pela experiência, me ocupei em conhecer o modo como eu percebo e como a emoção sentida pela luz se comunica com as imagens. Estas qualidades sensoriais simples que encontrava nas janelas eram os componentes fundamentais da imagem. Volto à luz como ideia, por ser ela a imagem da própria experiência. Ao mesmo tempo que ela se manifesta fisicamente como energia radiante, existe algo que nos afeta. Ela não age por nossa determinação, simplesmente é o que é, e sua presença é constante e inerente à imagem. Supor que vemos aquilo que queremos ver é construir uma imagem de luz para nós. O mundo que percebo é impregnado de luz, e isto a torna substância.

Os desdobramentos estéticos destas ações artísticas abrigam registros virtuais de um olhar ativo e fenomenológico como agente potencial na construção das imagens de luz. Sobre a minha atenção, como observadora das coisas, existe a minha presença que também é uma imagem que se modifica pelas ações de apreender uma coisa. Deste conhecimento particular apreendido nesta complexa matriz de relações e reações percebidas, alimento meu repertório sobre a ação da luz e sua intimidade com a imagem. 
PAUSA ...

As palavras dão lugar a uma outra janela Vindas de um devir entre o espírito e a matéria. 


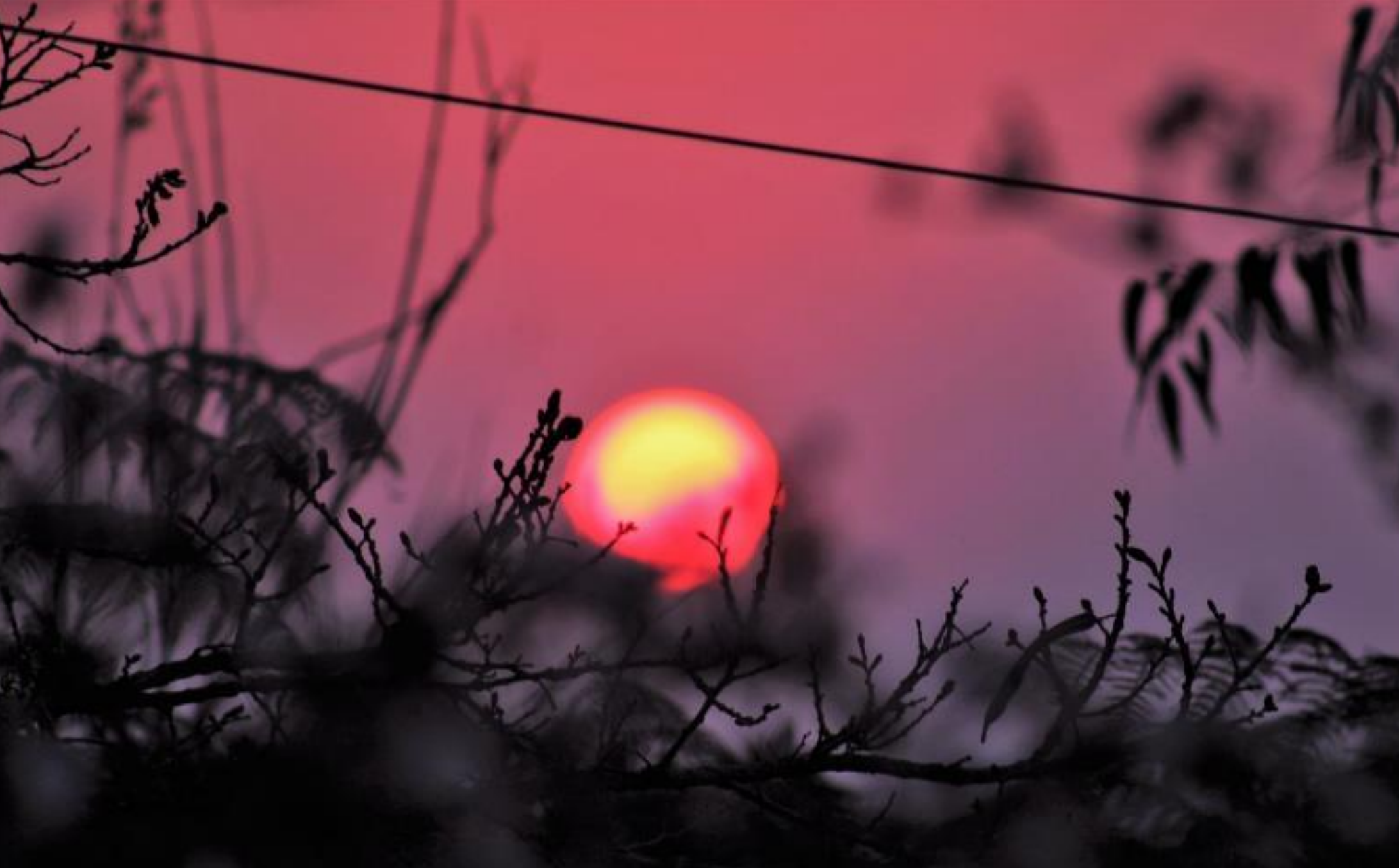


Num dia de setembro de 2018, já primavera, final de tarde na serra da Cantareira, São Paulo.

Em frente a tudo um ipê branco florido, mas tão florido que seu caule não sustentava tamanha floração e formou-se um tapete branco ao seu redor. O sol caminhava para seu esconderijo, naquele dia travestido de rosa, como um potente 'contra luz', lembrando um daqueles cicloramas difusos de Bob Wilson. Eram tantos e diferentes rosados que já se via do vermelho ao azul. Tudo era visto através do ipê que cobria parte da vista por seus galhos e flores, como uma moldura sugerindo à imagem um enigma. Não era um dia igual, pois quando olhamos para o céu com a devida atenção nenhum dia se repete, nada permanece. Um suspiro longo compunha o quadro. Era possível sentir a presença do sagrado, o sol deixava de ser apenas a estrela que brilha e o céu era mais que o ar. A atmosfera densa transportava para um outro lugar: a magia, o mundo invisível de possíveis bruxas e feiticeiras que ali habitam, como a noite das Walpurgas visitadas por Goethe ou onde Oxum e as feiticeiras de Yámi Oroxongá preparam seus feitiços na floresta. A fumaça do caldeirão contaminava o céu de amor e 
fecundidade. Sei que algo estava fora da ordem. Na imagem percebia-se uma fina película, a membrana do imaginário... um lugar onde as barreiras entre os mundos são permeáveis, luz e sombra se comunicam. A moldura segurava uma narrativa subjetiva, um outro lugar inaudivel, invisivel e mágico. O olho chega preciso, transparente, faz o recorte e cristaliza a imagem. É a dramaturgia da luz...

Cláudia de Bem, 2018 
Hoje já distante daquelas janelas gêmeas de Campos Elíseos, outras vão surgindo e dando lugar a outras experiências. A gênese desta "O Pôr do Sol das Feiticeiras" se manifestou num Culto a Oxum, numa roça de Candomblé na serra da Cantareira, que comecei a frequentar em 2017 e de cuja casa hoje sou filha. Por ser meu primeiro contato com essa religião, o conhecimento e minhas percepções sobre o assunto derivam da presença nessa casa onde aprendi um pouco sobre os rituais e oferendas. No Candomblé, os cultos são dirigidos aos Orixás que simbolizam forças da natureza personificadas na forma de ancestrais divinizados. As Festas ou Cultos sempre acontecem em templos chamados de roça, terreiro ou mesmo, casa. Cada Orixá se distingue por suas energias e habilidades distintas, bem como por suas preferências rituais. Nossa casa é de linhagem matriarcal, na pessoa da mãe de Santo. Realizamos um Culto mensal em que preparamos todas as oferendas inerentes àquele Orixá. Nessa roça, depois de um ano de convivência, fui erguida Ekedi, um cargo feminino que significa zeladora dos orixás. Ser erguida significa ser escolhida e confirmada pelo Orixá da mãe de Santo, que na nossa casa é lemanjá. As Ekedis não entram em transe, e uma de suas funções está em auxiliar no preparo das oferendas e cuidar dos laôs, filho(a)s durante os transes, zelando pela presença dessas forças e de seus filhos.

Naquele dia de setembro era festa de Oxum, também chamada Osún, Osúm ou Oxun, a senhora das águas, criadora do candomblé, um Orixá que representa a feminilidade, a delicadeza, a paixão e a fecundidade como essência da vida. Nessa festa 
não é incomum haver choros e fragilidades, pois sua sensibilidade e força do feminino é transferida para seus filhos. Nesses dias iniciamos as funções às 7 da manhã. Assim que entramos na roça, alguns rituais de iniciação e preparação são realizados individualmente. A saudação aos Orixás, as vestes, o banho de folhas e as reverências a todos da comunidade de forma hierárquica são práticas comuns nos cultos. É nesse estágio que começamos a nos distanciar da vida cotidiana e estabelecemos uma relação comum naquele coletivo. A preparação no Candomblé representa um estado preliminar para os cultos. Durante o preparo das Oferendas, que chamamos de comida de santo, vão acontecendo os ritos. Todo o preparo das comidas é para os Orixás, com especificações rígidas para cada um. Portanto, o grupo vai assumindo uma ação coletiva religiosa e vai se estabelecendo um estado preparatório para o culto. Naquele dia era Oxum que comandava e, na minha fantasia, por desconhecer profundamente a mitologia dos Orixás, tinha Oxum como força feminina, de amor e equilíbrio. Existem várias qualidades de energia representadas num Orixá, mas naquele dia, o que pressenti foi uma energia densa que me abateu fisicamente, e apesar de eu não entrar em transe, me curvava. Procurei a mãe de santo para compreender tal estado e ela respondeu: Oxum também é feiticeira, minha filha. Talvez naquele dia tenhamos sido visitados por Osun Abòtò, uma anciã, representação de Oxum ligada às feiticeiras, pois no final da tarde, quando achei que havíamos encerrado a cerimônia, no céu Oxum se manifestava, era o "pôr do sol das feiticeiras". 


\section{PONTO DE INTERSECÇÃO 2 - REFLEXOS MUTANTES}

Desde 2009 tenho me dedicado a investigar as manifestações físicas da luz natural na matéria orgânica e as possibilidades de diálogos com a performatividade. Postulei inicialmente a hipótese de que a relação de friç̧ão entre luz e corpos é indissolúvel, e capaz de gerar organicidade para uma ação performativa e/ou teatral, acreditando que

essas imbricações ampliam perspectivas no processo criativo da performance, do designer de luz e do performer. O foco de interesse da pesquisa estava em abordar possibilidades artísticas e expressivas da luz a partir da realização de laboratórios, onde estímulos luminosos fossem especialmente concebidos e materializados no sentido de afetar a percepção de um corpo e sua consequente criação de movimento.

Numa visão mais holística entre a luz e a natureza como matéria artística das investigações, incorporei nestas ações o papel de observadora e pesquisadora na experimentação direta com o fenômeno. A ação inicial da pesquisa consistia em captar em vídeo imagens atraentes filtradas pelo olhar num livre exercício de observação, experimentação e percepção da manifestação da luz natural nas águas. Neste exercício surgiram descobertas plásticas, poéticas. A propriedade ilusionista da luz de transfigurar a matéria ao vê-la refletida nas águas, num elemento transparente e em constante movimento por sua fluidez, estabeleceu simultaneamente uma relação subjetiva com as imagens naturais e uma conscientização sobre como nos relacionamos com a natureza 
das coisas e as reinventamos, dando outras formas. Deste lugar surgem os estímulos luminosos, termo que eu lavrei na ocasião. Filtrados pela minha sensibilidade e percepção, foram levados a interagir com outro corpo na perspectiva de um desdobramento dessas imagens através de outro olhar sobre elas. O espaço físico criado para as experiências era uma sala vazia de $10 \mathrm{~m}$ de largura por $20 \mathrm{~m}$ de profundidade, dividido por uma tela translúcida de $4 \mathrm{~m}$ de largura e 2,10 de altura para projeção dos estímulos (fig.3). O espaço de ação da performer era restrito ao limite de projeção na tela. O corpo trabalhava de frente para as imagens e a câmera da pesquisadora ficava no outro lado, a uma distância de cerca de $5 \mathrm{~m}$ da tela, onde eram captadas as interferências da performer em silhueta sobre as imagens projetadas. O resultado era outras imagens formadas pela fusão de três elementos de distintas composições: luz, água e corpo, um corpo-mídia que se metamorfoseia no espaço. O resultado era uma imagem de qualidade híbrida na forma em que o corpo se unia ao espectral da imagem. O desdobramento estético dessa pesquisa resultou na obra Reflexos Mutantes ${ }^{34}$ apresentada em videoinstalação, reproduzindo fragmentos destas práticas colaborativas realizadas durante seis meses com a performer, bailarina Thais Petzhold.

\footnotetext{
${ }^{34}$ Reflexos Mutantes. Disponível em <https://www.youtube.com/watch?v=1ZjdlB_rkYcAQUI $\geq$
} 


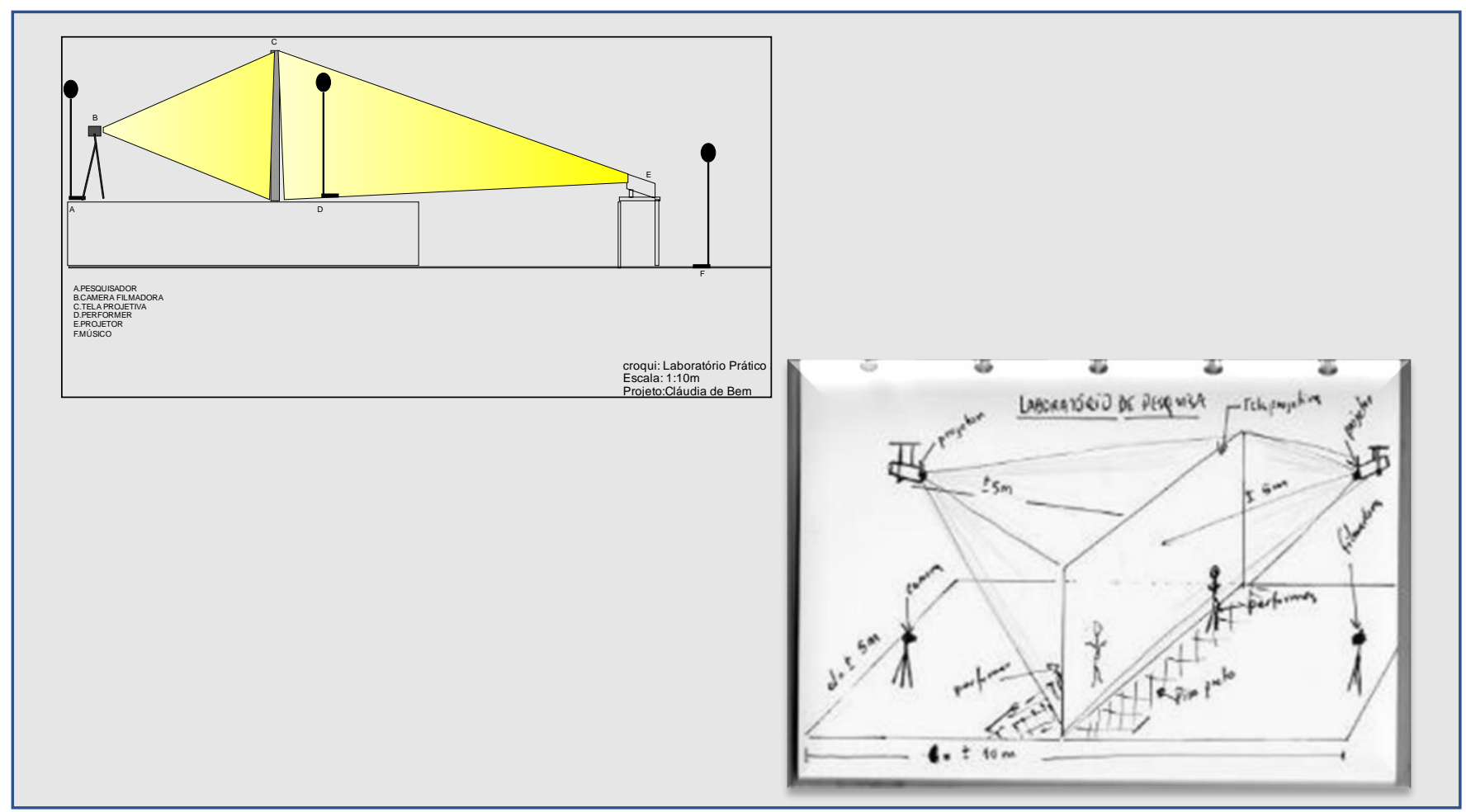

Fonte: a autora

A reflexão sobre os desdobramentos dessa pesquisa foi examinada num estudo mais pragmático - "A luz, o iluminador e o performer: uma experiência perceptiva"35 (fig.4)

\footnotetext{
${ }^{35}$ BEN, 2014
} 


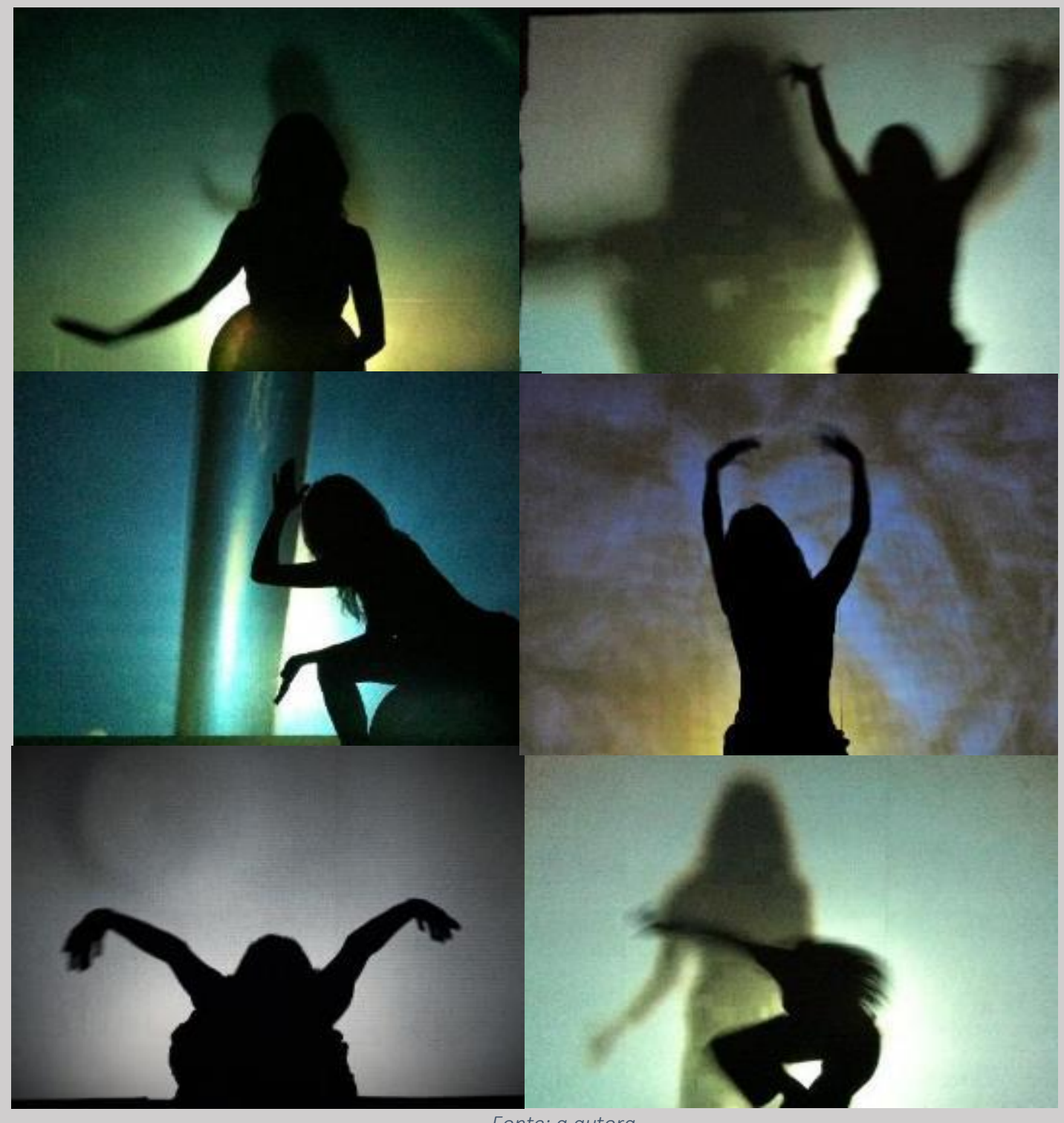


Da hipótese inicial - propor uma experiência artística ao performer, em que a luz fosse o estímulo - acho que fomos mais além. Ao refletir sobre a luz nesse processo, vejoa diluída no todo, e a experiência direta com o fenômeno através da percepção na sua manifestação natural revelou ser substância sensível capaz de gerar novas estratégias de percepção ao performer num permanente diálogo entre a pesquisadora-iluminadora, o estímulo luminoso e o performer.

Diferente de experiências anteriores como iluminadora cênica, lidar com a luz estava além do contexto de um espetáculo, transgredia a hierarquia da concepção de uma cena. Havia subversão nos papéis, a luz materializada em imagens sensíveis desencadeava a ação do performer. Noutro momento, a pesquisadora assumia o papel de receptora da experiência do performer que, sobreposta ao estímulo, criava outras imagens. Havia várias camadas e olhares desde a captação e representação do estímulo, a prática do performer, o olhar do pesquisador. Por fim, a interação era representada pelo processo da ação coletiva e mutante em que experimentávamos concomitantemente sensações, memórias e emoções singulares sob diversas óticas. Na posição de observadora, percebia um corpo que modificava, transgredia as imagens e expressava um novo texto visual e imagético, um corpo que dialogava com parte de mim. Não havia palavras, e sim dois olhares sintonizados. Ao partilhar com outro corpo minhas sensações e percepções sobre essa integração de luz, corpo e natureza, eram reportados 
pontos comuns da interatividade. A mediação tecnológica implicou numa ampliação do campo de recepção da experiência e em compreender outras interlocuções existentes. O vídeo foi a tecnologia mais apropriada para essa interatividade entre as experiências no tempo real em outra relação corpo-espaço-tempo.

Em Reflexos Mutantes, o convite era para experimentar um espaço sensorial impregnado das atmosferas das experiências vividas pelo performer e pelo pesquisador. Uma porta para outros olhares e outras camadas perceptivas dessa poética. Reflexos no sentido de refletir, ampliar, desdobrar e Mutantes por ser um processo híbrido, em permanente movimento. Foi uma experiência de fruição dos sentidos em outra relação de tempo. Na instalação existia uma correspondência com a atmosfera construída nos laboratórios, nosso pacto de silêncio sobrevivia ali. Durante a visitação, o público receptor permanecia em estado meditativo e contemplativo. Os depoimentos espontâneos coletados durante a visitação da obra descreviam emoções e percepções próximas das nossas experiências e sensações, como solidão, isolamento, imersão em si.

Pelas características e movimentos que eu estava percorrendo ao investigar as relações da luz, arte, natureza e corpo veio a necessidade profunda de renovar os conceitos e compreensões dos meus atos artísticos. Por que iniciar com a natureza? Talvez porque ali a luz é equilibrada e se manifesta por si só, na sua forma mais pura, sem a manipulação pelo ser humano. A natureza como referência passa a não ser uma representação dela, mas a criação através dela, a reinvenção de um outro modo de agir focando em práticas e 
interações com o meio ambiente. Com o tempo, essas posturas fenomenológicas de ir às coisas mesmas para investigar o fenômeno, impressas nas práticas de investigar a luz, impulsionaram processos perceptivos e um repensar a relação corpo-natureza.

Com essas experiências estéticas, comecei a identificar intencionalidade numa arte ligada ao ambiente, pois surge da necessidade de observar o meio natural através da luz e suas conexões com o mundo e nossa existência - esse existencial no sentido dado pela fenomenologia, de um espaço de realização de existir no mundo. A luz passa a ser o fenômeno que escolhi como deflagrador de ações artísticas que fazem repensar outras conexões. 


\section{BIFURCAÇÃO IV - O SAGRADO DA LUZ}

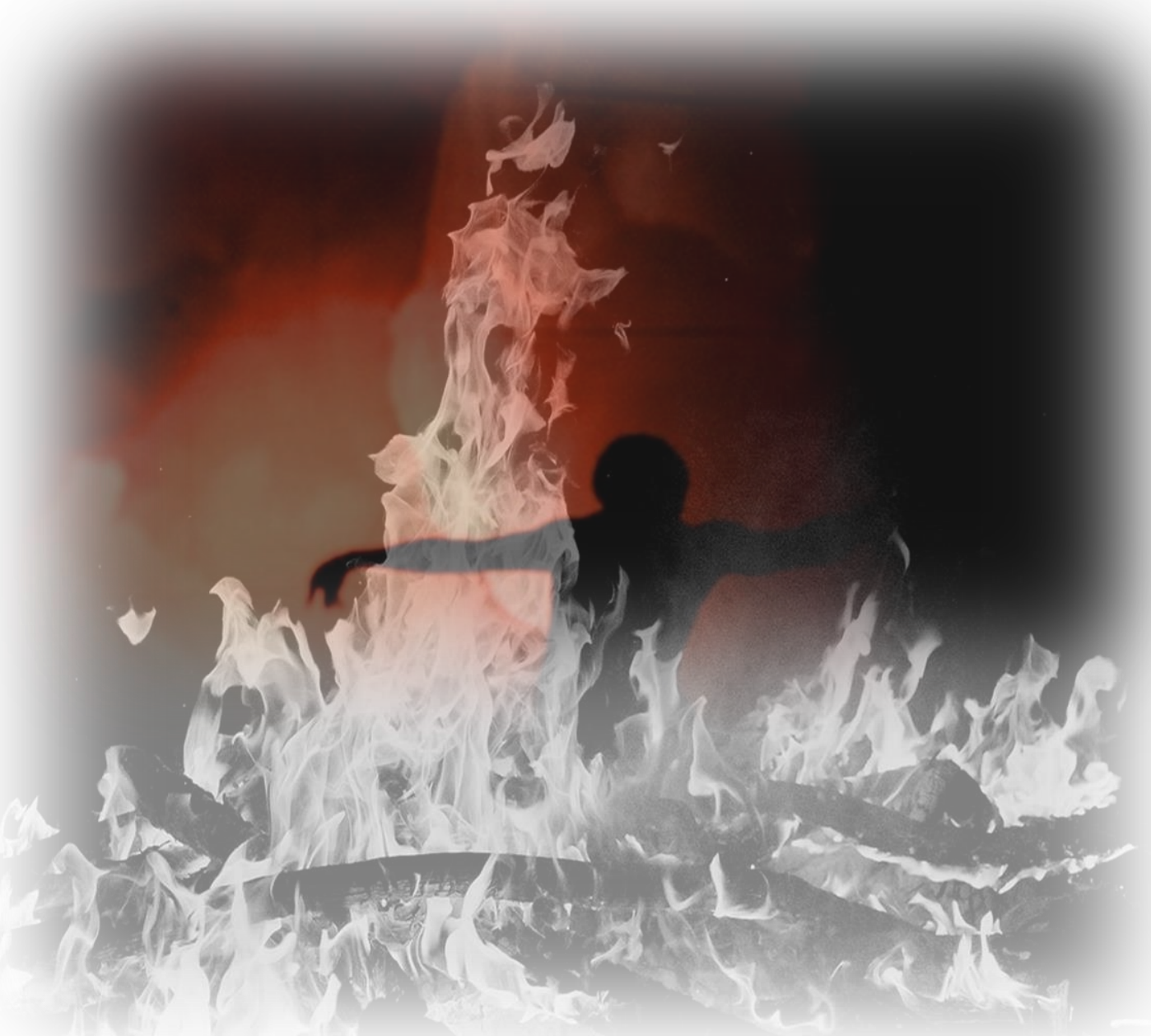


Dando continuidade à investigação de outras potencialidades e dimensões que a luz poderia revelar, iniciei novas ações colaborativas com outro elemento - o fogo: para mim, uma representação sagrada da luz.

Se a luz tem caráter transgressor, o fogo, luz primordial e secular, por si só é uma performance luminosa. A princípio, pensei em examinar o fogo numa conotação simbólica e depois como elemento performativo de luz. É fato que a utilização do fogo como metáfora atravessa milhares de anos da nossa civilização, e ainda o identificamos ligado ao misticismo, à teologia e à filosofia. Sem pretensão de aprofundar conceitos filosóficos tão complexos, nos interessa propor algumas breves considerações sobre a simbologia do fogo, por constatar a presença dessas memórias nas performances e compreender, através dos relatos e ações dos performers, o elo simbólico estabelecido com esse elemento. Também na descrição das narrativas que seguem, agrega-se o breve passeio cognitivo pela filosofia à experiência estética sensorial e fenomenológica numa performatividade em que a ação surge no espaço constituído por todas as manifestações dos performers, da pesquisadora e do fogo.

Percebemos sua presença em vários cultos e ritos religiosos e culturais das mais diversas origens, desde o passado mais remoto até o presente, o Ser do fogo é trans histórico. Analisado pelo prisma da tradição filosófica desde os gregos, encontramos nos pensadores pré-socráticos - posteriormente denominados por Aristóteles como filósofos da natureza (fisiólogos) - a preocupação em compreender a natureza (phýsis) como 
totalidade substancial do mundo. Eles revelaram doutrinas sobre o Elemental num contexto cosmológico ${ }^{36}$. Perguntavam-se sobre a origem e o princípio (arché) das coisas num aprofundamento sobre o natural, questionando as antigas crenças mitológicas. A maior preocupação desses primeiros filósofos era encontrar uma substância originária ou um princípio fundamental que daria nascedouro a todas as coisas. Dentre eles, Heráclito de Éfeso, reconhecido por sua obscuridade e enigmas, considerava o fogo como um constituinte cósmico primário responsável pelo equilíbrio entre a alma e o mundo. Para Heráclito, o fogo é o arquétipo da matéria. A ideia da unidade do ser expressa pelos filósofos pré-socráticos conferia um estatuto ontológico aos elementos naturais, ao suporem a existência de um princípio material universal: a imanência desses elementos em todas as coisas explicava a permanência da unidade material da natureza sob a aparente modificação das formas exteriores. Suas filosofias e teses fundamentavam-se em imagens de experiências sensíveis e não em conceitos científicos empiricamente comprovados. Por esta razão, foram desacreditados inicialmente por Platão 400 a.C., ao introduzir um pensamento divisionista sobre o mundo que dava à razão a supremacia da verdade. O sensível era incerto, de aparência. O conceito de imagem é de tal forma complexo e amplo que está presente em diversas problemáticas pertinentes a essas

\footnotetext{
${ }^{36}$ Uma fonte de esclarecimentos e ponderações filosóficas sobre a concepção que relaciona kósmos, arché e phýsis segundo os pré-socráticos e Aristóteles pode ser encontrada no artigo de Miguel Spinelli - a noção de arché no contexto da filosofia dos pré-socráticos. Revista Hypnos, n.8, 2002. Disponível em: <http://www.hypnos.org.br/revista/index.php/hypnos/article/view/124/126> Acesso em ABR2020
} 
diversas áreas e encontramos em Platão um dos primeiros questionamentos sobre o estatuto da imagem. Em seus textos a imagem é entendida como aparência (em grego 'eikon') e ocupa um lugar central na discussão sobre como nos relacionamos com o mundo visível. Para ele, as imagens faziam parte do mundo sensível e não podiam dizer a verdade sobre as coisas, porque a verdade pertencia ao mundo das ideias, por isso era necessário diferenciar a aparência (imagem) da essência (verdade).

A luz já permeou vários discursos na humanidade, e a relação entre trevas e luz é uma memória cultural coletiva ocidental que reside no mínimo há 400 anos. Platão utilizou a luz para traçar um discurso educativo, de posicionamento frente ao mundo. A luz do sol vista como supremacia, vida e bem maior, um alcance ao inteligível e ao fogo foi dada às trevas, representadas pelas sombras; o acesso ao mundo sensível é um engano e leva à ignorância. Apesar de a corrente racionalista ter imperado por muitos séculos e reprimir qualquer expressão de conhecimento sensível por experimentação, ele sobreviveu clandestinamente em pessoas que viviam à margem, como bruxo(a)s, feiticeiro(a)s, curandeiro(a)s e alquimistas. Por sorte, com o tempo, estes conceitos foram sendo modificados, mas ainda permanecem vestígios que a humanidade compartilha em rituais, culturas e atitudes perante a vida. A evolução do pensamento e a visão mecanicista das ciências foram distanciando essa unificação de espírito e natureza.

O filósofo romeno Mircea Eliade em sua obra O Sagrado e o Profano, destaca esse comportamento de dessacralização histórica do homem profano que resultou numa 
desconexão com o sagrado atribuído aos fenômenos naturais. Desta personificação das forças da natureza e conexões com as subjetividades é que foram criados os mitos como potência sagrada de consagração da vida. Muitos mitos se tornaram universais e ainda representam a memória coletiva de determinadas culturas. Assim, todos nós carregamos um simbolismo mítico e místico herdado de um passado, mesmo que não seja percebido por ele. “Assim como a 'Natureza' é o produto de uma secularização progressiva do Cosmos obra de Deus, também o homem profano é o resultado de uma dessacralização da existência humana [...]"37.

Segundo Eliade, o homem profano, queira ou não, conserva os vestígios do comportamento do homem religioso ${ }^{38}$, mas esvaziado de significados religiosos. Faça o que fizer, é um herdeiro. Não pode abolir definitivamente seu passado, porque ele próprio é o produto desse passado. É constituído por uma série de negações e recusas, mas continua a ser assediado pelas realidades que recusou e negou. Para obter um mundo próprio, dessacralizou o mundo em que viviam seus antepassados; mas para chegar aí, foi obrigado a adotar um comportamento oposto àquele que o precedia - e

\footnotetext{
${ }^{37}$ ELIADE. 1992,p.166

${ }^{38}$ Segundo Mircea Eliade, o significado do natural é visto pelo homem religioso como uma sacralidade dada pelos Deuses que constitui um Cosmos, e esta conexão com o Cosmos presente nos mitos e nas sociedades primitivas e arcaicas foram se diluindo através dos tempos num processo de dessacralização da existência, dando lugar a uma sociedade materialista, que transita e crê num mundo profano que duvida da manifestação do sagrado a ponto de ameaçar sua estabilidade.
} 
ele sente que esse comportamento está sempre prestes a atualizar-se de uma forma ou outra, no mais profundo de seu ser ${ }^{39}$.

Mircea Eliade declara que o religioso é parte constitutiva do homem, mesmo com a transformação dos valores sofridas no decorrer da história, ele carrega raízes profundas e sustenta sempre um diálogo entre o sagrado e profano. Apesar do distanciamento estabelecido pelo ser humano contemporâneo da religiosidade, a relação que ele estabelece com os símbolos míticos e místicos ainda habitam no inconsciente, permanecendo ocultas, revelando-se num imaginário.

Este tema, mais tarde, foi aprofundado e ampliado num discurso sobre imaginação simbólica pelo filósofo francês Gilbert Durand ${ }^{40}$. Ao conceber uma cultura do imaginário, se debruça sobre os conceitos de símbolos e arquétipos como componentes enraizados numa memória cultural coletiva preocupando-se com a maneira que as imagens são produzidas e transmitidas e sua recepção.

O propósito aqui é trazer esta relação entre o sagrado e profano e o momento em que nos deslocamos de um estado para o outro. Diante disso e das considerações trazidas por Micea Eliade, utilizamos o termo hierofanias para nominar as experiências práticas com o fogo. Hierofania significa na sua etimologia o ato de manifestação do sagrado na matéria. Ao considerar o fogo como detentor de uma sacralidade ao se manifestar como

\footnotetext{
${ }^{39}$ ELIADE, 1962, .p.66

${ }^{40}$ Ver.DURAND, Gilbert. A imaginação simbólica. 1979
} 
luz, utilizamos o termo para expressar que algo de sagrado se revela. As hierofanias estão representadas nas ações artísticas da pesquisadora e performers em práticas com o fogo. Nesses percursos imagéticos circundantes, os corpos vivenciam e imprimem à imaginação uma livre e infinita associação que surge da relação luz-corpo-espaço. O processo perceptivo prevalece sobre o cognitivo, e a base informativa está nas sensações individuais dos performers e da pesquisadora.

Nas práticas revelaram-se essas camadas perceptivas individuais, favorecendo olhares plurais diante das experiências, e foi possível constatar a presença de memórias coletivas inseridas e a consonância com a simbologia mítica e mística, assim como outras referências do universo íntimo de cada performer. Ao identificar um padrão de iniciação das práticas que demonstra o quanto carregamos camufladas em nós essas referências que transcendem o mundo profano, assumi durante as práticas a sintonia da luz com o sagrado, da luz que transcende e se transfigura em outra forma, o fogo. 
Acredito que todos estabelecemos rituais espontâneos na vida cotidiana e, se nunca paramos para descrevê-los ou nos conscientizamos deles, mesmo assim nos acompanham em determinadas ações do dia a dia, místicas ou não. Eu tenho alguns bem presentes, e quando habitamos o universo da pesquisa, nos deparamos com eles e os reorganizamos em outra estrutura, transformando-os em outro ritual. Compreender esta organização cria relações objetivas e subjetivas com os procedimentos metodológicos. Destes movimentos vão se alinhavando ações, interações e a construção do fazer. É neste contexto, que as operações metodológicas foram incorporadas como ritos, por localizar em suas estruturas uma ressonância dos conceitos sobre a temática ritual de Van Gennep, Turner e Schechner, bem como a escolha e apropriação de alguns termos como ritos, liminaridade e communitá.

Cabe trazer a este domínio de realidade simbólica o olhar antropológico de Victor Turner, que vai ao encontro dessa dimensão do imaginário singular e plural:

Os símbolos possuem as propriedades de condensação, unificação de referentes díspares, e polarização de significado. Um único símbolo de fato, representa muitas coisas ao mesmo tempo, é multívoco, não unívoco. Seus referentes não são todos da mesma 
ordem lógica, e sim tirados de muitos campos da experiência social e da avaliação ética ${ }^{41}$.

Primeiramente, o conceito de liminaridade foi agregado por Turner a partir da obra do antropólogo alemão Arnold Van Gennep ${ }^{42}$ ao examinar a estrutura de ritos de passagem - separação, margem e agregação. Van Gennep, ao constatar que a margem tinha uma complexidade diferenciada e independente das outras fases, desenvolveu um simbolismo que denominou de ritos liminares - aqueles executados durante o estágio de margem. São os ritos entre a separação e a agregação, espaço entre os ritos preliminares e pós-liminares, a passagem de um mundo ao outro, do profano ao sagrado, aquilo que antecede um novo estado. Para nós importa apenas tomar por base as considerações de Turner sobre seu estudo antropológico das práticas rituais observadas na tribo dos Ndembu, na África Central $^{43}$, sem acompanhar os avanços de sua teoria que estabeleceu paradoxos e ambiguidades, contestando estruturas internas da sociedade e tentando compreender essas falhas através dos conceitos de liminaridade. Turner define ritual como uma manifestação religiosa ou ligada a certo grau de sacralização - no sentido amplo do termo - em que, por meio de representações simbólicas, suscita-se um estado liminar dos

\footnotetext{
${ }^{41}$ TURNER, 1974, p.71.

${ }^{42}$ GENNEP, 1978

43 Turner contribui para esta temática após seu estudo de campo junto ao povo Ndembu, na África Central. Do estudo formulou suas teses sobre liminaridade e conceitos de communitás, e mais tarde, ante estrutura.
} 
indivíduos, o que provoca uma reelaboração simbólica do espaço e tempo, e os relativiza. Identifica liminaridade num ponto de margem dos ritos de passagem, como um momento de condição transitória no qual os indivíduos apresentam-se indeterminados, um entrelugar indefinido em que não são plenamente caracterizáveis. Communitás ele denomina como uma ante estrutura constituída pelos vínculos entre os indivíduos (não territoriais) que compartilham uma condição liminar em momentos especificamente ritualizados. Também atribui aos sujeitos liminares agrupados nestas communitás um estado de isolamento, silêncio e submissão, como um estágio para assumir a nova posição depois do rito de passagem. Para ele, o atributo liminar do ritual é potencializador dessas relações das communitás e objetiva a mudança nos indivíduos e/ou no coletivo.

Para Schechner ${ }^{44}$, "Rituais são memórias em ação, codificadas em ações". Este conceito ampliado diz respeito a implicações de uma memória viva, não somente a lembranças ou num plano racional, mas aquilo que está no corpo, nos objetos, nos símbolos ou codificações que são utilizados nas práticas rituais.

O termo ritos foi incorporado para descrever as operações metodológicas dentro destes conceitos subjetivos de espaçamento de Van Gennep, e descrever as zonas de liminaridades de Turner avistadas no campo perceptivo instaurado, nos pactos de silêncio estipulados na preparação, nos objetos utilizados e simbologias análogas. Nem o tempo e nem as pessoas nele envolvidas se encontram nas mesmas condições de suas vidas

\footnotetext{
${ }^{44}$ LIGIÉRO (org), 2012, p.49
} 
cotidianas. A própria impossibilidade de designar um lugar de verdade já dava a noção de liminaridade. Existia essa passagem de um mundo (cotidiano) a outro (espaços das experiências). Estávamos descentrando estruturas, criando valores, estruturando realidades, nos investindo de novos paradigmas.

Retorno ao conceito de Schechner ${ }^{45}$, em que realizar performance interliga o sendo, fazendo, mostrar fazendo e explicar este mostrar fazendo por achar uma similaridade com os ritos que compactuaram com as ações metodológicas.

Como iniciar diálogo com uma luz que performa com independência e carrega na sua ação incontrolável um desconhecido, uma noção de divindade simplesmente por ser? Coloco-me na condição de que seremos dois agindo em comunhão, o elemento e eu. O ser nesta experiência não é estático e é circular. Duas ações com diferentes estados de matéria, físicos e espirituais em busca de um eixo fundamental que nos defina. O fazer e mostrar fazendo é nossa ação e reação, aquilo que permitimos um ao outro, nossa disponibilidade de mirar e ressoar criando um fluxo entre as ações. O explicar implica no olhar que carrega o percurso imagético que constituiu a experiência, o ressignificado.

Na trajetória de um processo criativo, é difícil as expectativas não nos assombrarem, há sempre um aspecto intuitivo na ação e filosófico na construção da ação. Não é uma operação lógica e racional. Todo o tempo, um paradoxo se manifesta pelo deslocamento do olhar desde a contemplação do elemento e as relações que surgem.

${ }^{45}$ Ibidem 
Nessa circularidade da forma aqui representada, encontram-se múltiplos vetores: nosso olho, o corpo e seus deslocamentos, trajetos circundantes sem arestas, onde atmosfera não é construída, ela te constrói fundida nas histórias desses corpos livres em que escutamos os ruídos transbordantes das fronteiras entre a arte e o espaço. Entre o mundo imaginário e mítico destes labirintos habitam personas liminares como bruxas, xamãs, magos, alquimistas e os artistas.

Desenhos, escritos, imagens, frequências, atmosferas, movimentos e não movimentos, palavras ditas e não ditas vão dando forma a estes espaços circundantes. É num carrossel de imagens representadas por linguagens diversas que construímos a base estrutural dos experimentos e a formulação de conteúdos e reflexões acerca da luz e sobre o fazer criativo interligado à construção de uma nova ação performativa, prospectando ampliar a percepção do performer nas relações da luz e o meio natural com a nossa própria condição de existir e perceber o mundo.

Em Hierofanias, reconheço a performance como resultado de uma reação alquímica no sentido de misturar os ingredientes (corpo-luz-imagem), encontrar a química entre eles, transmutá-los, dar outra forma híbrida gerada por essa alquimia. Alquimia como transformação e transmutação da matéria, termo utilizado nas reflexões teóricas de Artaud e no Teatro e seu Duplo Espiritual, onde ele vinculava o teatro aos princípios essenciais da alquimia, a fusão entre matéria e espírito. Neste povoado de olhares, ambiguidades e oposições que se configura a performance como um processo alquímico. 
Todos os percursos imagéticos percorridos pelos performers e a pesquisadora foram captados em vídeo, e o desdobramento estético é a vídeo-performance Hierofanias, que contém estas narrativas subjetivas, suas correspondências, confidências, sonhos e memórias filtrados pelo olhar da pesquisadora. São fragmentos de um trabalho de pesquisa ao longo de três anos envolvendo sete laboratórios práticos in loco com o fogo e o corpo. Os espaços onde ocorreram as experiências eram rurais e distantes de centros urbanos, cada um com características próprias de vegetação, localização geográfica, moradores e relações afetivas com a pesquisadora. Os relatos das experiências, bem como a descrição dos espaços, se encontram na ordem cronológica dos acontecimentos:

1. O Manto Azul

2. Sítio Moinho Velho

3. UAP - Usina da Alegria Planetária

Nas práticas, o que estabelecemos como ritos foi mantido em todas as experiências, com poucas alterações, e se dividem em três:

Rito 1 - Esculpindo a luz (preparatório)

Rito 2 - Sacola de Talismãs (margem)

Rito 3 - Entrada no labirinto 
O MANTO AZUL

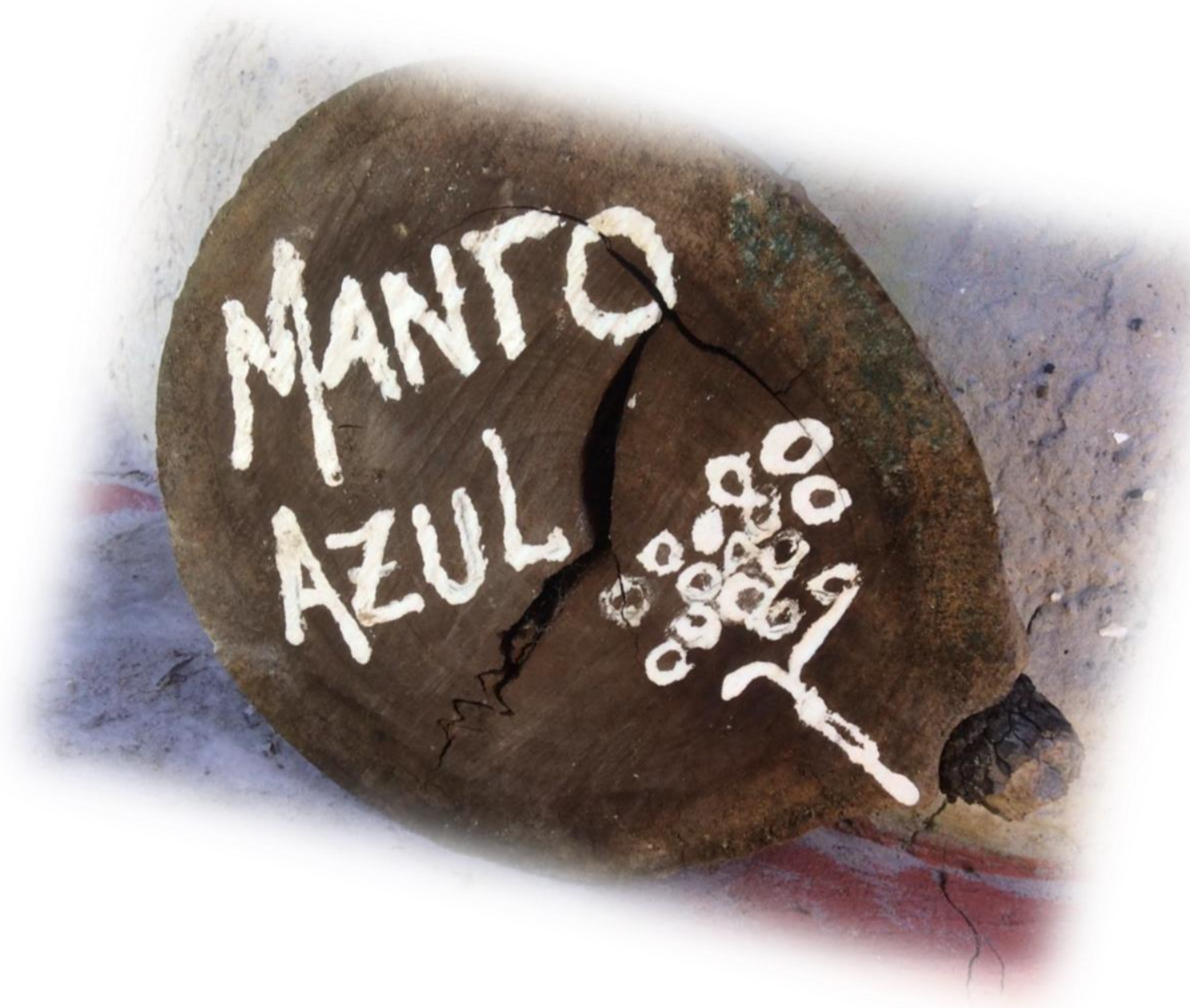


O Manto Azul está localizado na zona rural do município de São Francisco de Paula, na Serra Gaúcha, a cerca de 140 quilômetros da capital Porto Alegre. O nome se deve ao muro que circunda toda a propriedade, coberto de hortênsias que brotam na primavera em várias tonalidades, do violeta ao azul. Os proprietários são dois músicos - Carina Donida e Marcelo Figueiredo, que residem em Porto Alegre (RS) e se deslocam para lá nos finais de semana. O espaço externo é bem íngreme e com bastante mata virgem, pois não existe reflorestamento e nenhuma atividade de exploração da terra. A mata nativa é diversa, repleta de Araucárias, típicas da região. A casa fica num vale, a água provém de uma fonte natural e a energia é precária, sem comunicação via internet ou telefonia. Tenho muita familiaridade com o local pela relação de amizade com os proprietários, e fui hóspede por algumas temporadas quando um grupo se reunia para aliviar o stress cotidiano. Uma característica desse local é o céu que, por razões que desconheço, tem uma divindade enigmática na sua representação. Observar as estrelas sempre foi um ritual dos nossos encontros, em que estabelecíamos várias conexões com aquele espaço. São Francisco de Paula coleciona algumas histórias admiráveis, como aparição de OVNIs e de entidades místicas. Por um tempo, existiu um Observatório de OVNIs na região, e estudiosos, espiritualistas e místicos de inúmeras tendências migraram para lá. De fato, o céu tem um movimento intenso segundo nossas experiências de observação. Apesar de estar vivendo em São Paulo, iniciar ali tinha um significado afetivo, espiritual e metafísico; para mim, era um espaço sagrado, reconhecido por instinto, memória e presença. 
A construção das fogueiras representa o estado preparatório da pesquisadora para a passagem do mundo profano ao mundo sagrado. Esta etapa se funda num momento individual onde estabeleço uma relação com o espaço e a matéria, e preparo um campo perceptivo de atuação para o performer. Consiste também numa transformação do estado de um rito para o outro. Aqui se inicia um processo de purificação e de abandono do cotidiano para ingresso no espaço sagrado onde acontecerão as experiências. Nesta etapa, identifico o silêncio como operação metodológica por configurar um estado meditativo e de isolamento significativo para estabelecer o campo sensível da ação artística.

O croqui (fig.5) foi a primeira imagem estrutural criada como visualização do espaço necessário e definição do equipamento técnico para captação das vivências. Considerei como condição técnica mínima: área de atuação de $100 \mathrm{~m}^{2}$, local plano para a fogueira, ação dos performers e posicionamento das câmeras. Os laboratórios, ou hierofanias, foram feitos em três lugares, cada um com características geográficas diferentes e com significados particulares e afetivos para mim, cujas relações e conexões com lugarejos e experiências relato num texto introdutório. Farei o relato mais minucioso das primeiras experiências no Sítio Manto Azul, por serem as que solidificaram as operações metodológicas para a construção das fogueiras em todas as práticas. 
Na primeira hierofania, segui as referências do croqui, pois conseguimos três câmeras de vídeo a fim de obter uma captação em três ângulos. O plural aqui se dá pela presença de um querido amigo como colaborador no início da jornada, Mário Carvalho, músico e fotógrafo que acabei batizando de "meu guardião", e este apelido mostrou-se significativo no decorrer do processo. Esta condição técnica existiu apenas nas duas primeiras práticas. Nas restantes segui só, uma câmera, tripé, olhar e novos espaços.

\section{Figura 6-Croqui}

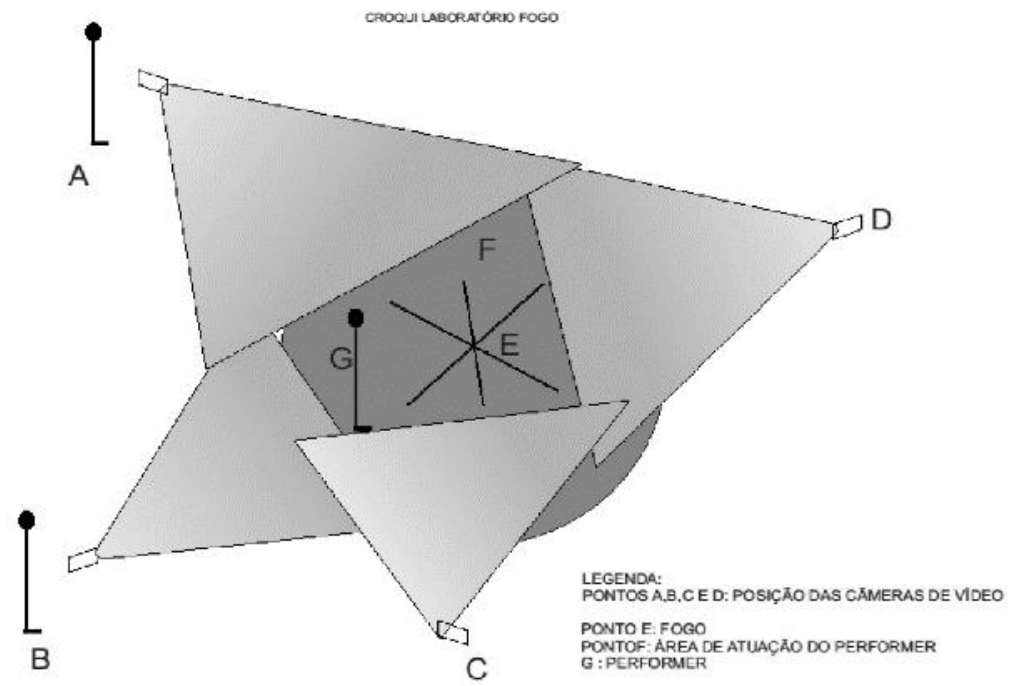

Fonte: a autora 
Partiu...

Em janeiro de 2017, partimos em caravana de dois, apelidada de "Caravana Hippie", uma brincadeira que estabelecemos pelo inusitado da experiência, a informalidade, a simplicidade das condições de hospedagem, as incertezas e, acima de tudo, o que nos conduzia: o prazer de experimentar, a disponibilidade. Inspirados no "On the Road", movimento da geração beat de Jack Kerouac - pegar a estrada respirando um certo nomadismo e a permissão de ausentar-se das tecnologias e do stress urbano (sem telefone nem internet). Em meio aos tripés, alimentos e inúmeras quinquilharias, seguimos em nossa "Caravana Hippie", deixando Porto Alegre às 8 horas de uma manhã ensolarada e quente rumo ao Manto Azul. Chegamos ao local às 14 horas. Descarregamos entusiasmados, a desbravar de imediato o espaço da ação. Mário topou a empreitada pelo seu hobbie de fotografia, assumindo a função de registro da pesquisa. Não existia nada definido, nem ordem de ações, apenas uma primeira ideia construída.

No momento de reconhecimento e diálogo com o espaço, existe uma subjetividade de pesquisador(a). Apesar do estabelecimento de operações metodológicas e sistemáticas, surgem outros espaços a serem visitados quando assumimos uma postura fenomenológica, sem antever nenhuma imagem interna. Pelo contrário, tentamos responder perguntas sobre ele. Como diz Merleau-Ponty, "[...] o espaço não é um ambiente (real ou lógico) em que as coisas se dispõem, mas o meio pelo qual a posição das coisas se 
torna possível $[\ldots]^{\prime \prime 4}$. Cada lugar tem camadas que variam entre materialidade e seus particulares segredos. O espaço tem um texto que diz o que está dentro e fora de nós, é a transcendência do profano para o sagrado, este limiar onde coexiste nossa singularidade. Assim também é no teatro, onde construímos espaços sensoriais. A atitude frente à imensidão e potência do meio ambiente nos causam impacto, a sensação de que algo nos separa, que não temos controle sobre aquele espaço de sons e presenças invisíveis. Aos poucos, aquietando, somos conduzidos organicamente à escuta, contemplação e reverência. Cada espaço tem uma voz, algo a ser escutado, experimentado e vivido. Apesar da presença de um colaborador, a definição do espaço físico, da construção do fogo, o montar a fogueira, suas camadas, o combustível seriam realizados apenas por mim, estabelecendo o rito de silêncio como ação metodológica e preparatória ao estado meditativo da pesquisadora, e por entender que fogo como luz sagrada habitava, até então, a minha subjetividade. Nesta decisão existia uma potência, o início da construção da primeira ação metodológica para a condução das práticas. A decisão não partia de uma imposição, ao contrário, era uma conexão e foi recebida num silêncio sem diálogos ou conferências entre nós. A generosidade e percepção de um sobre o outro assumiram a continuidade dos trabalhos. Agora era eu e "o guardião", assim senti o Mário, apenas por sua presença, protetor e cuidador. No silêncio, muitos outros diálogos são possíveis.

\footnotetext{
${ }^{46}$ MERLEAU-PONTY, 2011, p. 328
} 
Tenho por características ser ansiosa, impetuosa e desbravadora, mas às vezes isso se torna bastante perturbador. Não tinha nada pré-estabelecido para a construção do fogo, e apesar de certa familiaridade dada por minha herança cultural sulina, onde se faz fogo para acender a lareira ou assar churrasco, confesso que naquele momento percebi que a relação era outra. Sempre que inicio qualquer processo criativo, seja de um espetáculo, exposição, projeto de luz, busco entrar num estado que chamo de "zerada", sem referências ou imagens preconcebidas, e ali não foi diferente. Pensava mais em forma, dimensão, volume e tempo daquela luz, construí-la sem refletores, apenas com matéria orgânica. Ângulo, intensidade, contraste, movimento, temperatura da cor, qualidade de luz, fatores que consideramos fundamentais às escolhas para o desenho de luz pareciam não fazer sentido. Minha atenção se manteve no espaço, no material orgânico que o lugar oferecia como combustível dentro de uma ética ecológica, nada seria arrancado ou cortado. Por ser verão, havia folhas secas de araucária e de eucalipto, gravetos de diferentes origens e dimensões, lenha rústica - esta seleção e escolhas refletiram na qualidade e característica das chamas em cada local, pelas diferenças de composição e textura dos materiais. Após a coleta seletiva, separação e montagem, as camadas da fogueira se deram na ordem de combustão, do maior índice de queima para o menor, pensando em uma queima mais homogênea e com maior duração, e por facilitar o acendimento. Materiais como folhas secas, feno e gravetos ocupavam as primeiras camadas, seguidos de materiais mais consistentes, como galhos e troncos. Com 
o tempo, todo o processo de construir as fogueiras, desde a escolha do espaço, a coleta dos materiais e a montagem faziam parte do rito preliminar para mim: o momento de deslocamento do mundo profano e de conexão com a natureza. Essa etapa durava em torno de 6 a 8 horas no dia da realização das hierofanias. Eu colhia o material, separava por ordem de camadas e montava. A partir da segunda fogueira, adotei um método que se repetiu até a última hierofania:

1. Preparação do espaço para as fogueiras. Limpar o espaço, retirando tudo que poderia machucar o performer, visto que a luminosidade seria mínima e o fogo causava ofuscamento, o que diminuía a capacidade de visão.

2. Coleta do material

3. Separação do material por texturas e tipos de combustão

4. Registro dos materiais em fotografias para documentação

5. Montagem da fogueira

6. Confecção das tochas para acendimento

Existia uma similaridade com a sistemática do trabalho de iluminadora cênica na técnica e operacionalização da montagem de um espetáculo. A diferença estava em construir a luz, que, aqui era o próprio espaço. O estado meditativo já surgia como fundamental para estabelecer um campo sensível para o ápice criativo - o momento de construir o idealizado, que agora passava a ser externa e pertencer ao espaço. 
Meu senso estético começava a transparecer na construção da fogueira pela simetria - característica pessoal nos meus desenhos de luz. Um estado de suspense faz parte do universo do(a)s iluminadores cênicos, provavelmente de todos que trabalham com projetos luminotécnicos. A sensação ao montar as fogueiras era de esculpir uma forma que seria transformada em outra, isto me fazia pensar na estrutura e na luz propriamente dita. Na tarefa de sobrepor as diferentes camadas dos materiais, ia visualizando e abstraindo a forma desse corpo, os efeitos, as transições, os movimentos da luz, um desenho atípico, arquitetural e vivo. Depois de muitas horas de preparação, lá estava a estrutura de base larga e extremidades mais finas, esperando para ser descoberta e invadida pela luz. No decorrer das práticas, surgia uma habilidade ao criar essas esculturas. As primeiras fogueiras adquiriram uma forma circular e simétrica pelo tamanho, colocação e sobreposição dos materiais. Com o tempo, elas foram tomando outras formas, mais retangulares e espaçadas, criando novos espaços para as ações.

Outra questão identificada nas primeiras hierofanias foi na captação das imagens. As relações de luminosidade entre corpo e fogo eram muito diferentes para a sensibilidade do ISO da câmera. Para uma imagem do fogo próxima ao que víamos era necessário baixar a abertura. e isso reduzia a visibilidade do corpo do performer. Foi necessário criar um contra luz, ou seja, outra fogueira atrás da zona de atuação do performer para construir essas relações de contraste e tridimensionalidade. Incorporei essa decisão somente a partir da terceira hierofania. Apesar de manter os passos de 
montagem, nenhuma fogueira ficou semelhante a outra; como a luz em cena, nada se repete quando entendemos que a luz se faz através de relações com o espaço, e principalmente das ações humanas que agem nesse espaço. A meu ver, isso vale para todos os espaços, sejam eles cênicos, residenciais, corporativos, expositivos etc.

Concluídas essas operações, quase sempre no final da tarde, eu trazia o equipamento (tripé, câmera e acessórios) para fazer o enquadramento da área de atuação antes de anoitecer. Esse era meu espaço fixo. Depois definia outro espaço para o estado preparatório das experiências onde ficava o altar: o Oráculo com as cartas, o cachimbo, as tochas e o silêncio.

Nesse pequeno espaço sempre ficava uma vela acesa, que oferecesse um ponto de luz durante todo o trabalho. Por fim, estruturava meu espaço fixo da câmera. 
CAMADAS



166 


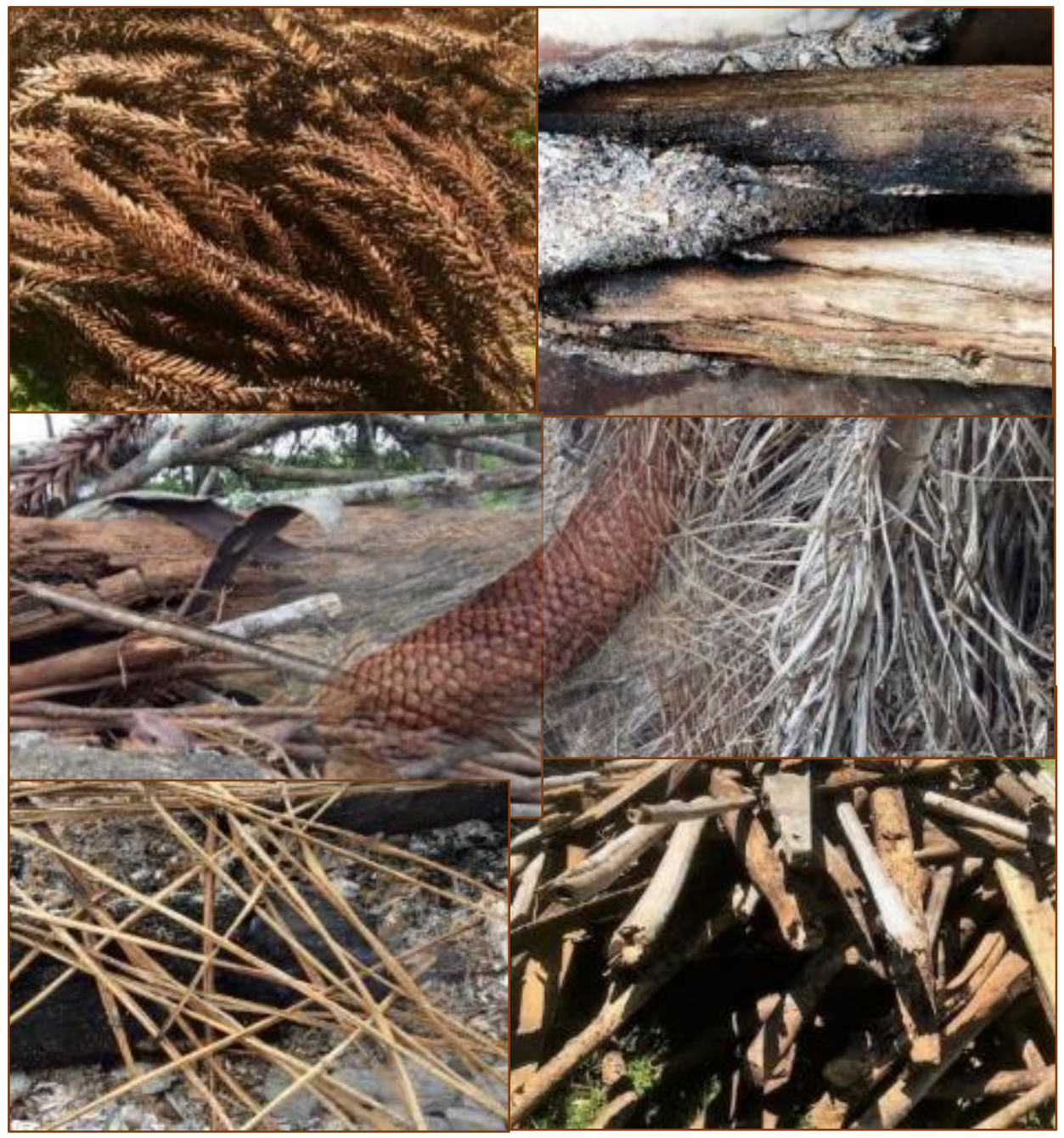




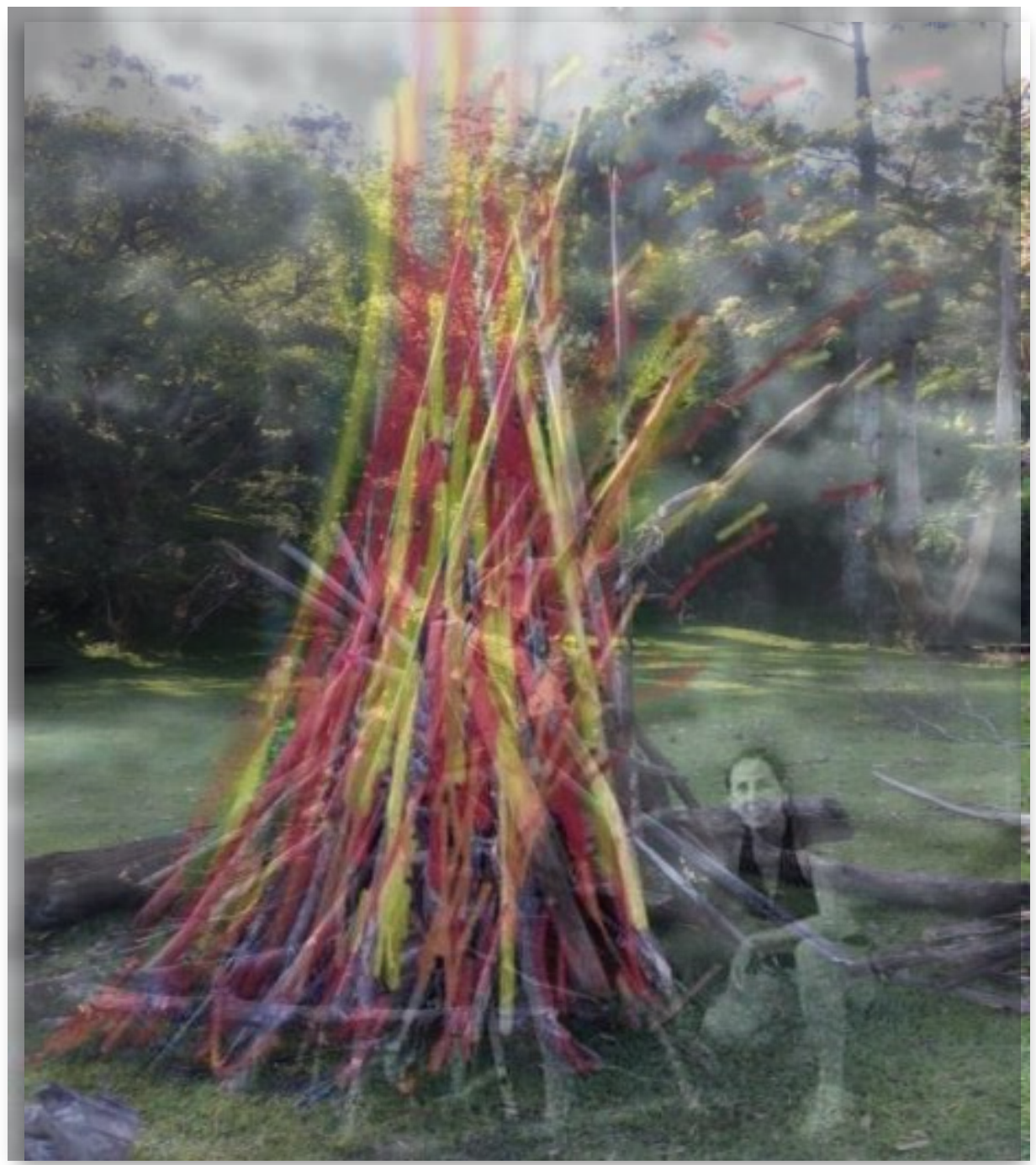




No íntimo, elegemos objetos que sacralizam nossa ação e fortalecem os argumentos intuitivos, como se criássemos uma conversa com outras personas. O rito estabelecido para acender o fogo vem acompanhado de objetos que moram na minha caverna platônica, meu mundo invisível e indizível. Neste repertório metafísico, trago figuras como curandeiro(a)s, bruxo(a)s, feiticeiro(a)s e xamãs, e algumas de suas sabedorias. Dentre elas, resgato um oráculo xamânico que já consultava anteriormente, as cartas do Caminho sagrado, quatro tochas para acendimento do fogo, o cachimbo (companheiro de noites tragáveis e intragáveis), a chama da vela e o silêncio (ausência de palavras).

O Oráculo foi organizado pela pesquisadora e professora norte-americana Jamie Sam, membro da comunidade indígena e profunda conhecedora do xamanismo, dos ensinamentos dos índios norte-americanos das nações Sêneca, Asteca, Choctaw, Lakota, Maia, Yaqui, Paiute, Cheyenne, Kiowa, Iroquesa e Apache. No Oráculo, ela reúne uma série de conhecimentos e sabedorias ancestrais, bem como os ritos de passagem cumpridos pelo xamanismo nessas comunidades e agrega cartas representativas dos ritos pertencentes a essas nações. Apesar das diferenças entre elas, a característica comum é a relação com a mãe terra. Todos os ensinamentos se relacionam com a observação da natureza e seus sinais, por isso cultuam o sol, a lua, os quatro elementos, os animais, as plantas etc. Com essa sabedoria da natureza e suas manifestações, compreenderam a conexão com o todo e estabeleceram uma forma de viver integrados à natureza como 
elevação da consciência. O baralho é composto por 44 cartas ilustradas com simbologias. Para nós, a consulta ao Oráculo tomou um significa do de guia, um ponto de contato entre a sabedoria e os rituais descritos nas cartas e as nossas experiências.

A preparação assumia a seguinte sequência: a retirada de uma carta guia para o trabalho e depois uma individualmente por cada pessoa presente. No meu diário pessoal, anotava a carta tirada e os dados de local, horário e nomes. A consulta ao oráculo poderia ser feita após o trabalho concluído, conforme o desejo de cada um. O próximo passo consistia em acender as tochas nas fogueiras, nos pontos representando os quatro hemisférios. Esta simbologia corresponde à roda de cura desenvolvida pelas tradições nativas norte-americanas, que vinculam os hemisférios à sabedoria das quatro direções e dos animais de poder. A Roda de Cura representa o eterno movimento, a trajetória do rito de iniciação do Xamã, em que cada hemisfério corresponde a um animal de poder e os quatro elementos: a cada direção percorrida pelo iniciado, um estágio e um aprendizado. O sentido para nós estava em acender o fogo num movimento só, em conectividade com o Oráculo, a Roda de Cura e os quatro elementos que ali precisavam existir em equilíbrio. São as conexões invisíveis, as memórias ancestrais.

Foram sete hierofanias, sete percursos.

Nas operações que se seguem, é necessário ao leitor pausar por frações de segundos na tentativa de estabelecer uma conexão com a experiência, pois chegamos a um lugar em que a palavra não alcança a dimensão do tempo da ação vivida; ela também 
é a prática e a imagem. As imagens também representam uma escrita, por vezes mais que a palavra, e esta ousa mudar a forma e se torna percurso na folha. As companhias que escolho além dos corpos residem no meu espírito, nas memórias e no estar no mundo. O estar é amplo, representa o transbordar da poética, um "estado" de presença transitável entre físico e metafísico, profano e sagrado. A arte, aqui, toma uma proporção de cápsula que abriga o corpo, o espaço e a experiência. Uma porta se abre para adentrar os mistérios, deixa de existir uma concepção definida, um domínio sobre o acontecimento. Esvaziar é transcender o espaço profano para permitir o encontro.

A Sacola de Talismãs significa as companhias que escolhemos para nos sintonizar no decorrer do caminho. 


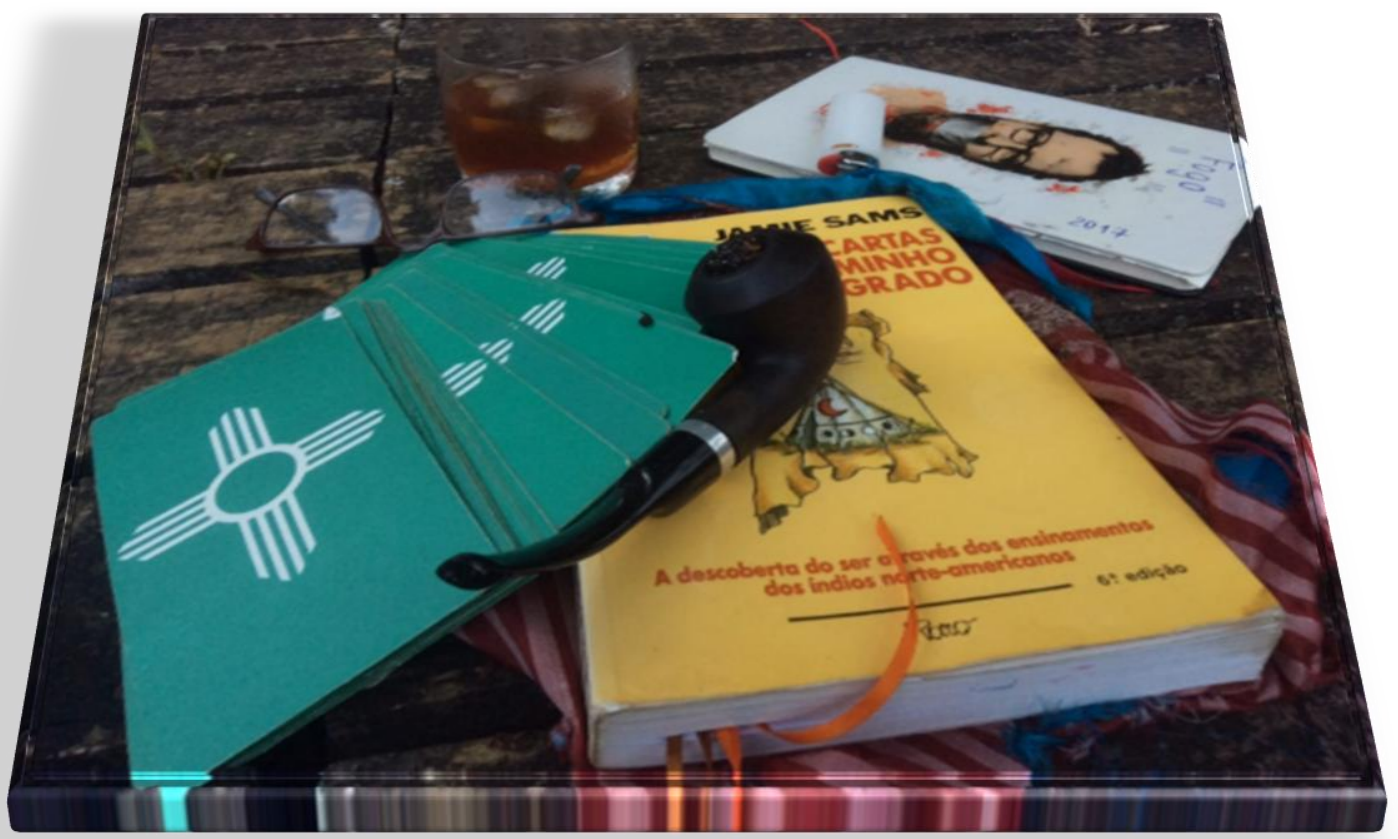




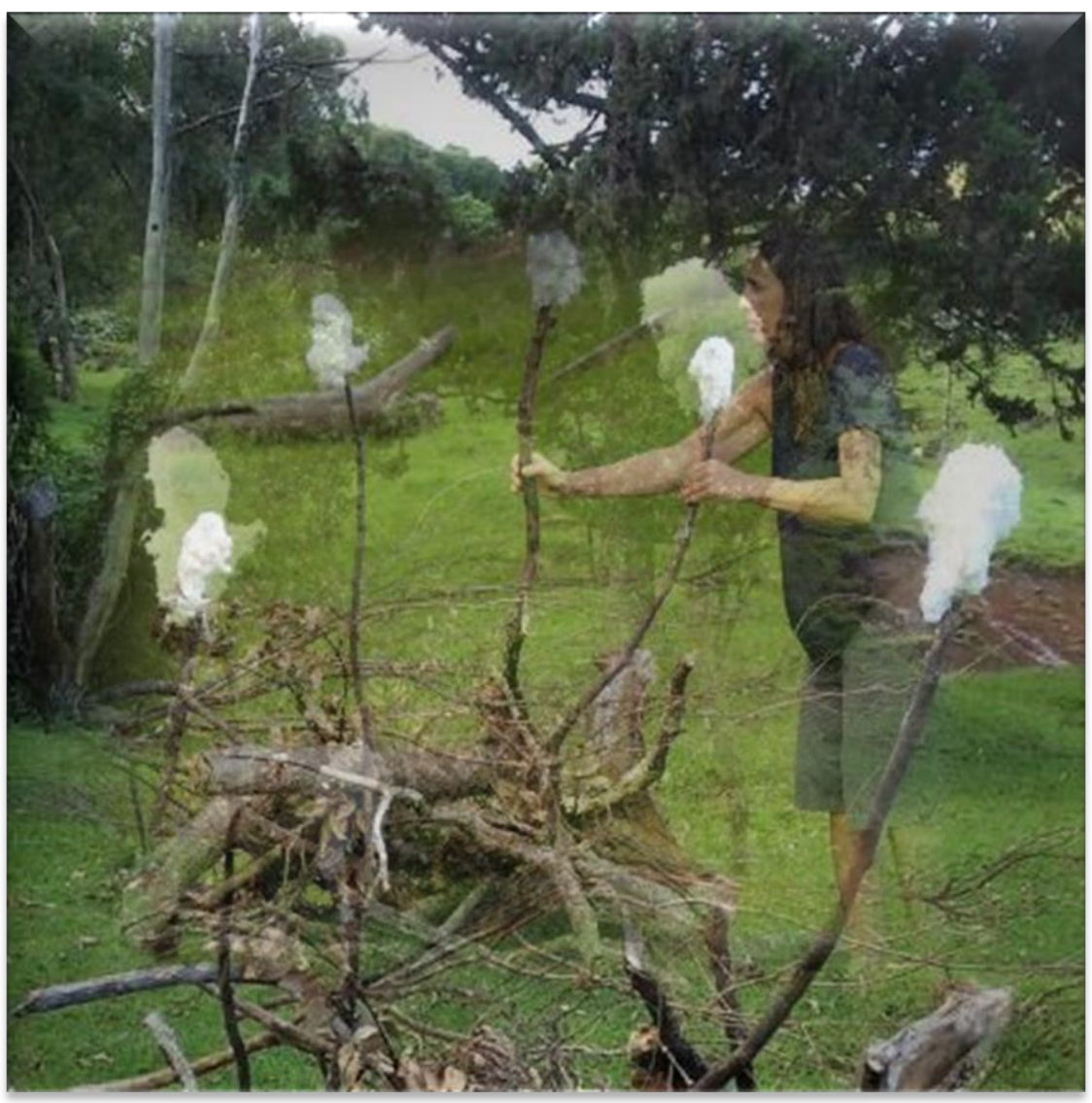

174 





Em hierofanias, os percursos são cheios de contrastes, um jogo de luz e sombra que se manifesta em diferentes formas e trajetórias. A luz incide em ângulos: laterais, frontais, diagonais, em contra luz. No centro, ela pulsa do chão, a chama-luz arde rumo ao céu e se ramifica. Levantando os olhos, avistamos histórias que nos pertencem e se distanciam para encontrar voz em nossos corpos. As experiências de luz são assim, um vagar no espaço encontrando corpos onde alguma porção fica, outra é absorvida e algo reflete nos nossos olhos, e passamos a ver o mundo e existir nele.

Tudo que ocorre a partir desse momento se relaciona com uma presença frente à luz, um enfrentamento, o transbordar de uma poética, um estado que transita entre o físico e o metafísico. Um diálogo entre matérias; presentes o fogo, o corpo e o espaço sagrado. As ações e reações urgem da singular experiência e a subjetividade do olhar sobre ela. Talvez a companhia de Artaud e seu teatro Duplo preencham esta presença na revelação da nova identidade que adquiro com a luz e o sagrado, a prática artística, o teatro e a alquimia destes encontros. Em comunhão, a escrita torna-se a prática. Imagens, palavras, sons e devaneios divagações vão desenhando a escritura dos percursos criados nestas zonas liminares da nossa communitá.

Após as experiências, é solicitado ao performer, ainda em silêncio, que transcreva num caderno suas anotações e impressões sobre a vivência. Aos poucos, começam a chegar os convidados; seremos muitos ao final. O que nos une nesta communitá são a presença, a 
disponibilidade e a arte. Nossos pactos são secretos e mágicos, e é no silêncio que comungamos. Os ritos de preparação desta fase começam ao entardecer, naquele vão em que o sol ainda espia e se despede. As tochas prontas para serem acesas, o cachimbo na mesa, a vela, o baralho, o livro. Deste lugar que a palavra já silencia, sentimos a magia, as conversas dos seres da floresta e do espaço, nossa trilha sonora. A percepção se aguça... O cachimbo é aceso junto com a vela, o oráculo nos chama e anuncia o movimento. A duração das experiências é o tempo do êxtase. A única regra é manter-se no espaço enquanto for habitável. O retorno é quando o tempo real voltar a existir.

O sol se foi ... Erguem-se as tochas para chamar nosso anfitrião: o fogo

O espaço ...o labirinto de luz 
ACESSO 2. Hierofanias

Entre todas as imagens, as imagens da chama - desde às mais ingênuas às mais apuradas, das sensatas às mais loucas - contém um símbolo de poesia. Todo sonhador inflamado é um poeta em potencial.

- Gaston Bachelard ( A chama da Vela) 
Data: 20/01/2017

Local: Sítio Manto Azul

Horário: 20h40m

Carta do trabalho: Carta 44 - O espaço sagrado

Acendendo fogo: $20 \mathrm{~h} 42 \mathrm{~m}$

Pesquisadora: Cláudia de Bem. Carta 36 - Seres do Trovão

Câmera 1. Lente: 70/20mm aberturas 2.8 macros.

Guardião: Mário Carvalho. Carta 1 - Lugar de Poder

Câmera 2. Lente: 24 mm abertura 2.8 planos aberto fixa.

Câmera 3. Lente: 24/105 mm abertura 4.0 móveis

Performer: Thais Petzhold (bailarina). Carta 43 - Cerimônia do Peiote

Convidado: Paulo (o pintor). Carta 7 - Roda de Cura 


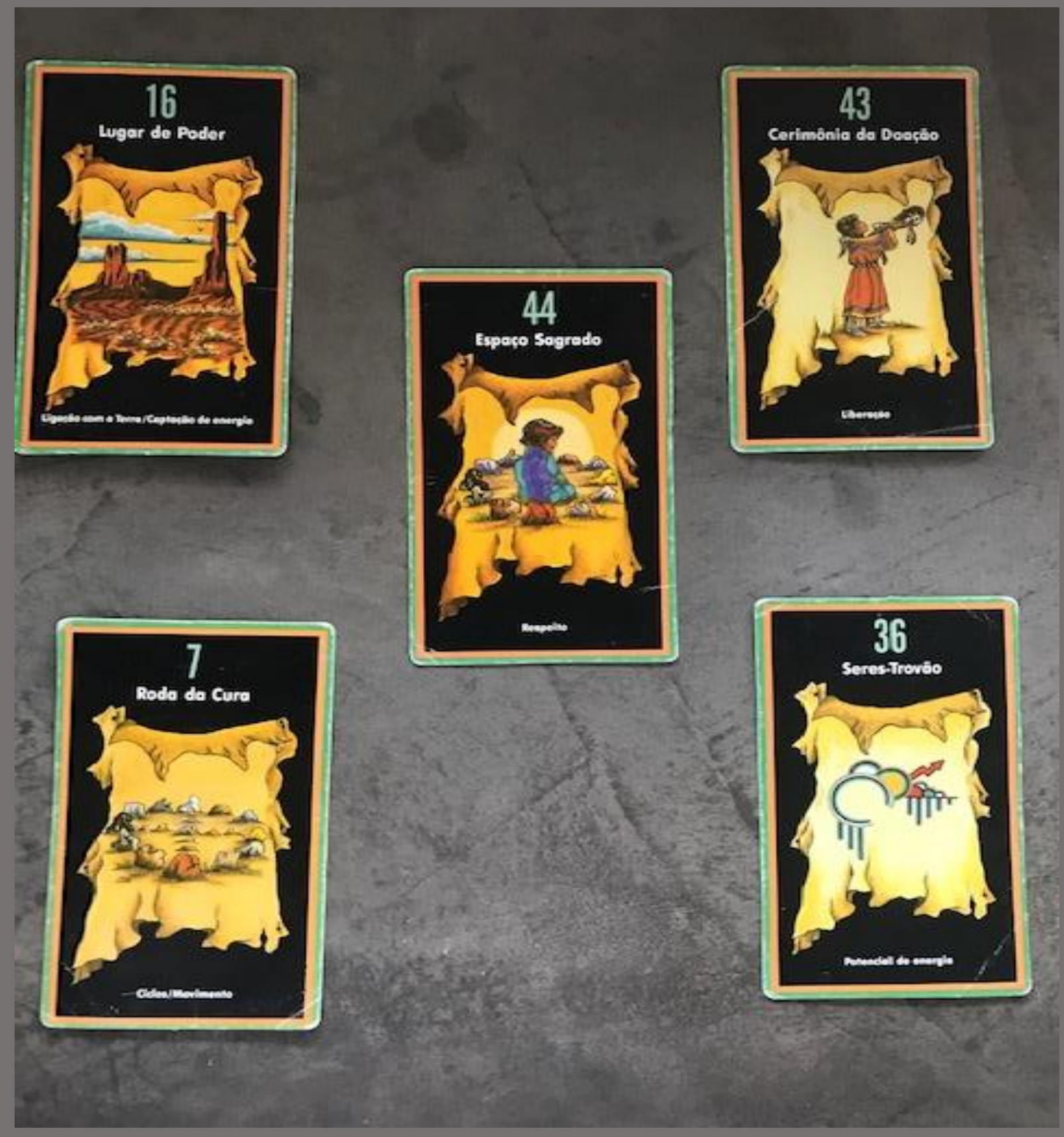


O ESPAÇO SAGRADO

Grande Mistério, ensina-me a honrar

As Leis do Espaço Sagrado,

Os costumes e Tradições

De todos os credos e raças.

Grande Mistério, me ensina a desenvolver

Os talentos que possuo

E a me comportar com respeito

Na casa dos outros.

Grande Mistério, ensina a criança que há em mim

A aceitar com graça

A parte do Mistério Sagrado

Encontrada em todos os espaços

Jamie Sam. Cartas do Caminho Sagrado, 1990, p.346 


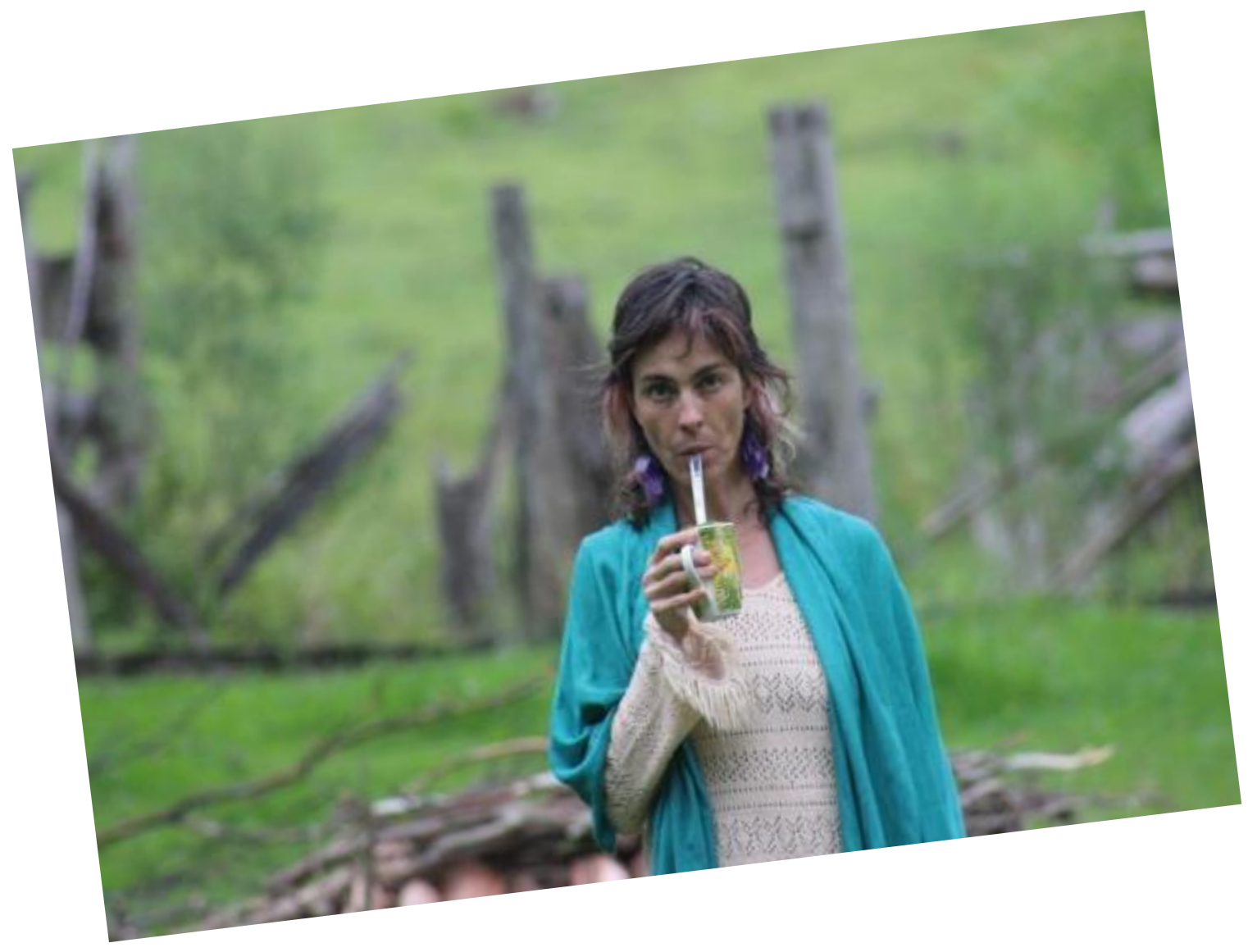

Crédito da foto: a autora 
Segundo este oráculo, o espaço sagrado não é somente uma crença filosófica e espiritual para os nativos. Tem a ver com o respeito por tudo e por todos. Desde a infância, as crianças indígenas aprendem a ouvir e respeitar os mais velhos e valorizar seus pertences pessoais e seus direitos e, os adultos respeitam as individualidades, independentemente da idade. O conceito de espaço sagrado extrapola o físico, diz respeito à sobrevivência, proteção e escolha. As crianças indígenas são encorajadas a intuitivamente descobrir seu espaço, onde possam ficar sozinhas de vez em quando.

Nosso primeiro movimento e vínculo iniciava assim, respeito e silêncio.

Posicionados, acendemos o fogo; naquele dia erámos 4 pessoas, 4 animais, 4 elementos. Nossa communitás: Eu, o guardião, a performer Thaís e seu companheiro Paulo, o pintor.

A luz sempre nos traz surpresas, nunca sabemos exatamente o que vai acontecer antes de acendê-la, com o fogo não é diferente. Nossa primeira fogueira foi uma explosão de luz em todas as direções. "Os seres do Trovão", a carta guia do Oráculo, fogo do céu que nos transforma e revela nossa essência, se apresentaram. Era difícil focar o corpo e o fogo pela diferença de luminosidade, precisava escolher e não contava com isso; foi meu primeiro desafio: tentar ajustar a imagem na câmera. A chama estava alta e parecia descontrolada, de repente uma explosão me fez derrubar a câmera no escuro. Sem imagem, sem câmera, me detive na performer. Eu estava distante, a uns 50 metros do espaço de ação, minha visão era diferente, achei que o fogo poderia alcançar as árvores, 
enfim... pânico. O vento, convidado que até então eu desconhecia, provocava diferentes trajetórias para a chama indomável e rebelde. As labaredas agitavam-se no céu, nos dando lambadas. Resolvi não interferir, a experiência era essa, agir com o acaso. O guardião estava longe com suas câmeras e parecia em paz, a Thais também. Ela rodeava o fogo numa postura investigativa. Paulo era um observador e, mais distante que todos, se acomodou. Fui apaziguando também, me sentia responsável por tudo e por todos, e o que via eram imprevistos. Era tão experimental e nova a experiência que não tomei precauções que assegurassem maior segurança à performer e ao espaço. Isto me deixou em estado de alerta, confiei no Mário para a captação das imagens e passei a assumir outros papéis necessários para o andamento da experiência, também não previstos. São estados diferentes que cada um assume e isto ficou visível durante as hierofanias. Meu olhar era no todo. Demorei para achar um equilíbrio para seguir, mas de fato o meu corpo assumiu uma posição de prontidão, e só depois me dei conta que ao longo da noite, eu ia construindo aquela luz. A tarefa de manter a chama acesa, alimentar a luz viva também era uma performance. Apesar de o objeto de estudo não ser a performance do iluminador na cena espetacular, percebo que, estando na posição de operar a luz num espetáculo, estamos performando, existe uma ação do iluminador na construção das imagens. O estado de prontidão acerca do acontecimento o conduz a um movimento que é refletido na cena. Não é uma ação mecânica, é feita de presença e conhecimento sensível. Olhando por esta ótica, ao operarmos a luz durante o espetáculo, não somos 
mais os criadores, somos performers. No decorrer da noite, que foi longa, uma atmosfera nos unia, coexistíamos nesse campo de presença. Um corpo aparentemente em transe habitava o fogo como energia geradora de todas as coisas, a conexão com o elemental. Tenho como referência de transe as incorporações das iaôs em roças de candomblé, quando manifestam as energias dos Orixás. Nestes ritos, existe uma alteração visível do corpo. Mesmo não se tratando de um espaço religioso, era um espaço sagrado, a ação da performer nos hipnotizava, os movimentos entre o fogo e o corpo se alinhavam, um duo em dança, uma coreografia liberta: a hierofania. Naquela noite, apesar de ser janeiro, fazia 13 graus. Thais entrou no espaço envolta num chale de lã, depois abandonou todas as vestes e se aventurou. Na sua ação e imagem, havia uma atitude primitiva e animal demonstrada por movimentos rasteiros apoiados em mãos e pés, como um primata. Não vou tentar descrever as imagens, eram tantas e nos restava sentir as dimensões do acontecimento. Posso apenas falar do meu olhar sobre o que via, e era muito, e meu relato mais verídico sobre estes estados alterados de consciência, creio estar nas imagens captadas com meu olho transparente.

Durante a experiência, debrucei-me sobre as imagens como representações verídicas que me permitiam compreender as passagens do corpo entre o simbólico, o sagrado e a presença através das ações e posturas assumidas pela performer.

Sobre o fogo como luz, não parei para contemplá-lo, me detive na alquimia dada pela manifestação do fogo, do corpo e da performance. Atribuo características sensíveis 
e visíveis às imagens, justamente por ver os acontecimentos através de um contato com a raiz perceptiva que os integra - o pensar a imagem de outra forma, como transparência da experiência, como outro diálogo com a luz. Eu fazia as escolhas através da câmera, tal qual o espectador, pois ele define o que ver. O criador de luz de uma cena tem a tarefa de conduzir o olhar do espectador para o que é significativo na dramaturgia, mas ao mesmo tempo a estética, a forma que ele conceitua ou pensa a imagem leva o espectador para outros lugares, talvez esta seja uma das diferenças entre visualidade e visibilidade. As imagens aqui são transparências do recorte do olhar, são fragmentos da performance. Em alguns momentos, me desligava da ação e agia pela hipnose do fogo e pela materialização de carrancas e animais que surgiam através daquele corpo de luz em movimento. O fogo performava como operador de imagens que nos fazem sonhar e era comum nos relatos dos colaboradores e performers, surgiam figuras tribais, seres indígenas, carrancas africanas e animais de poder, como águias, corujas, búfalos, cabeças de touro, serpentes. Não existe uma verdade que se possa atribuir a este imaginário, apenas aceitar que algo se pronuncia em nós na interação com o fogo que nos aproxima da cosmogonia da luz. A performance durou quase duas horas e, naturalmente, acabávamos a noite ao redor da fogueira, compartilhando sensações e impressões. Este espaço pós-experiência dava a dimensão da potência e conectividade da arte com a natureza. 


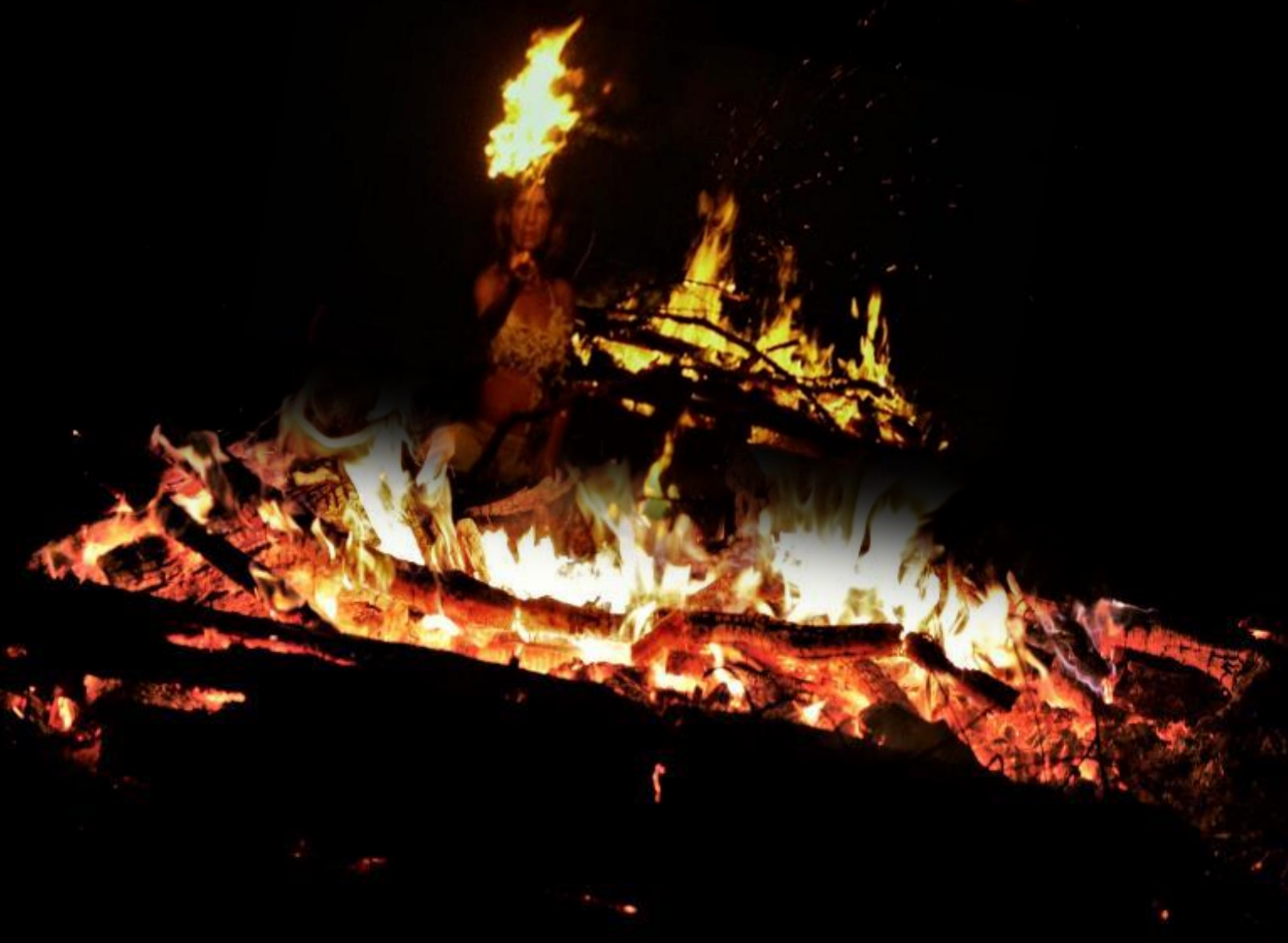




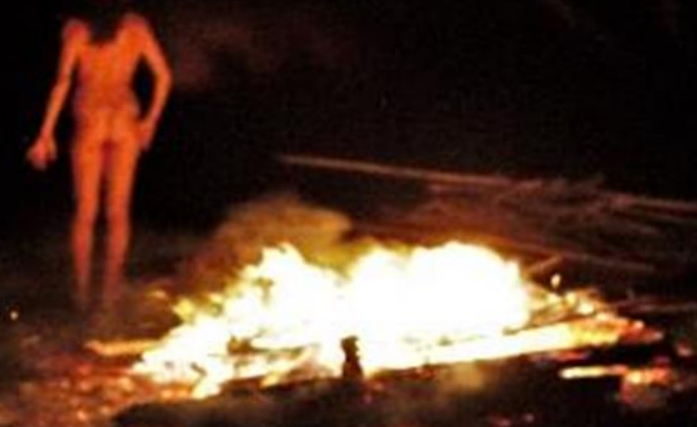



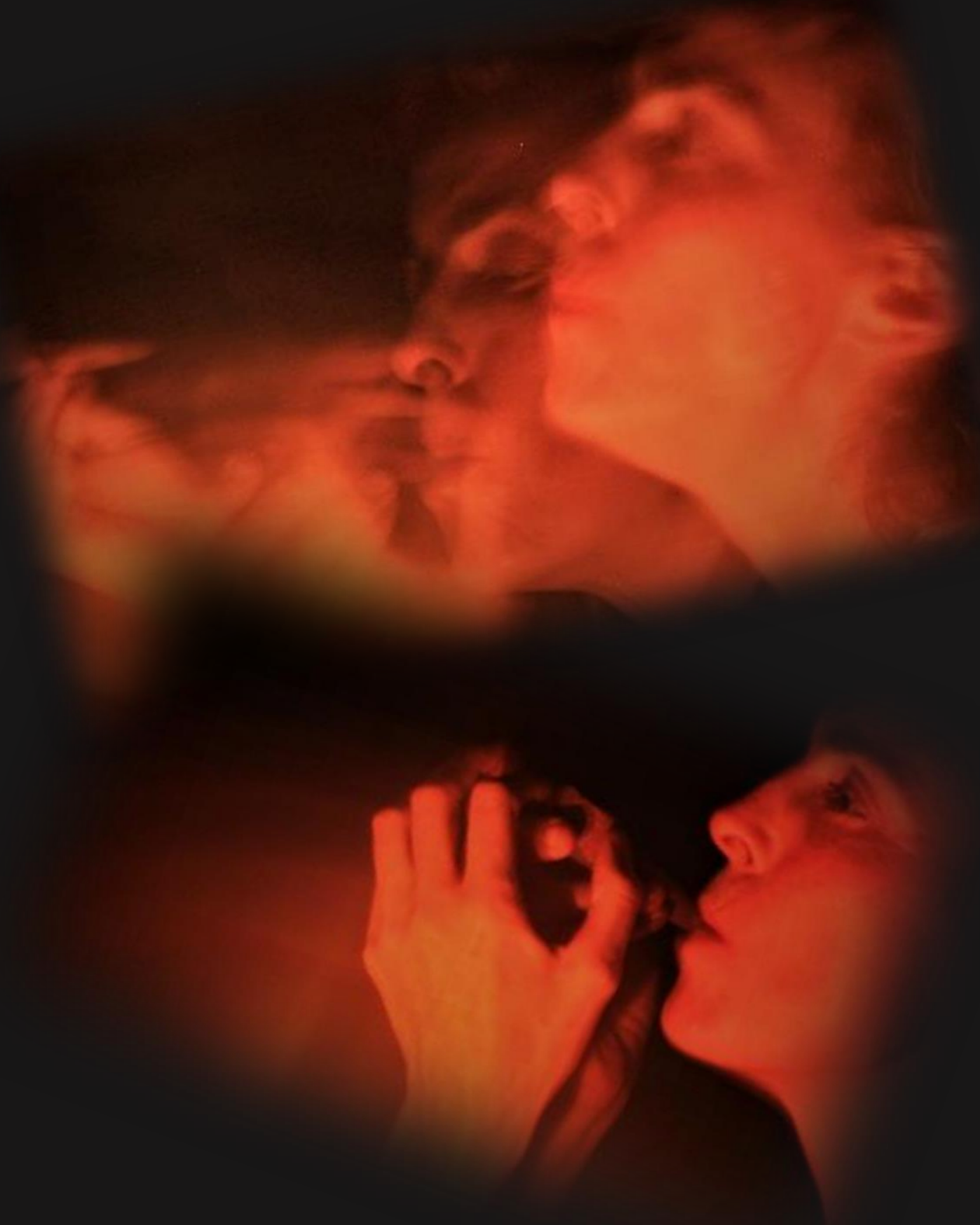


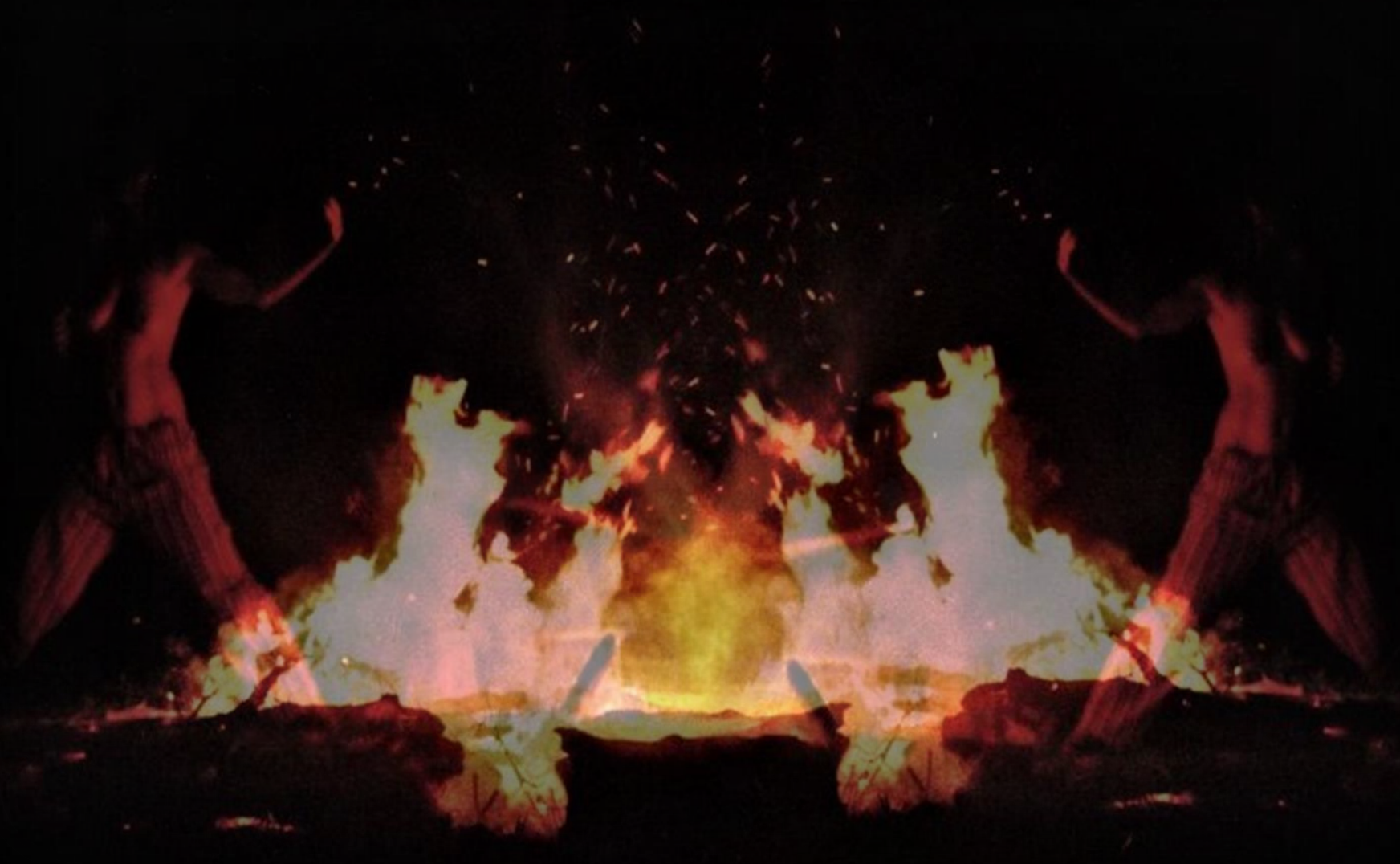



RELATOS DA PERFORMER

o que dobra

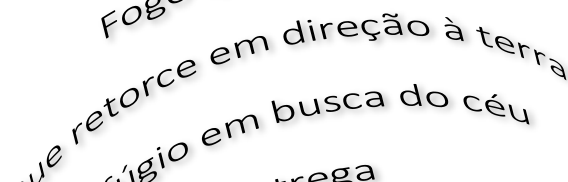

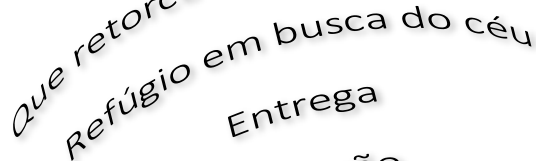

Estado de alerta

Respeito

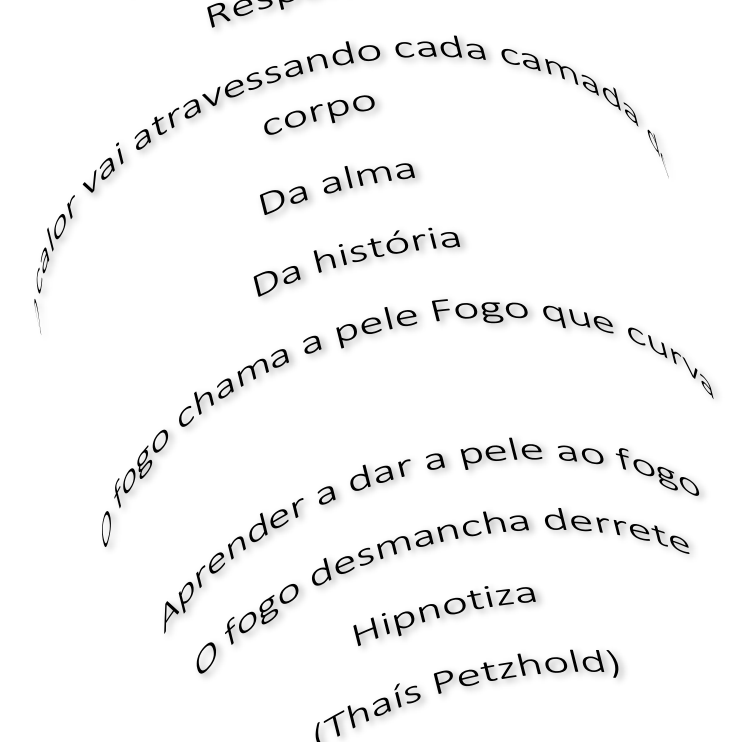

(Thais petzhold)

192 
zaco 00 fogo exige uma

jingala a momento $e^{2}$

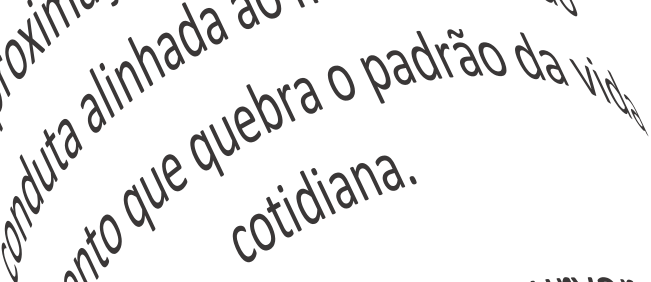

acer, ceder, curvar eaty

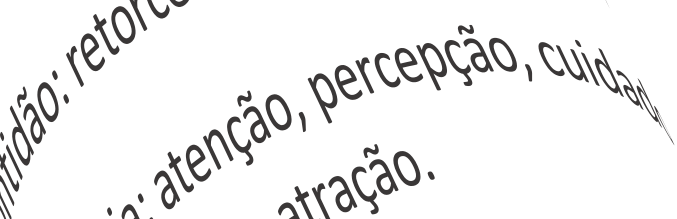

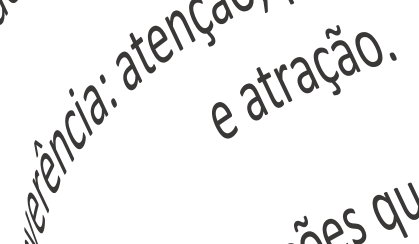

jes que geram granch

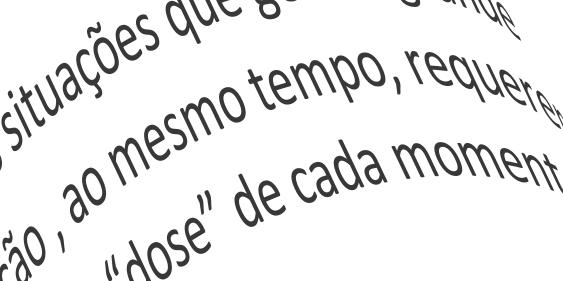

20" "agese de cada momento

193 


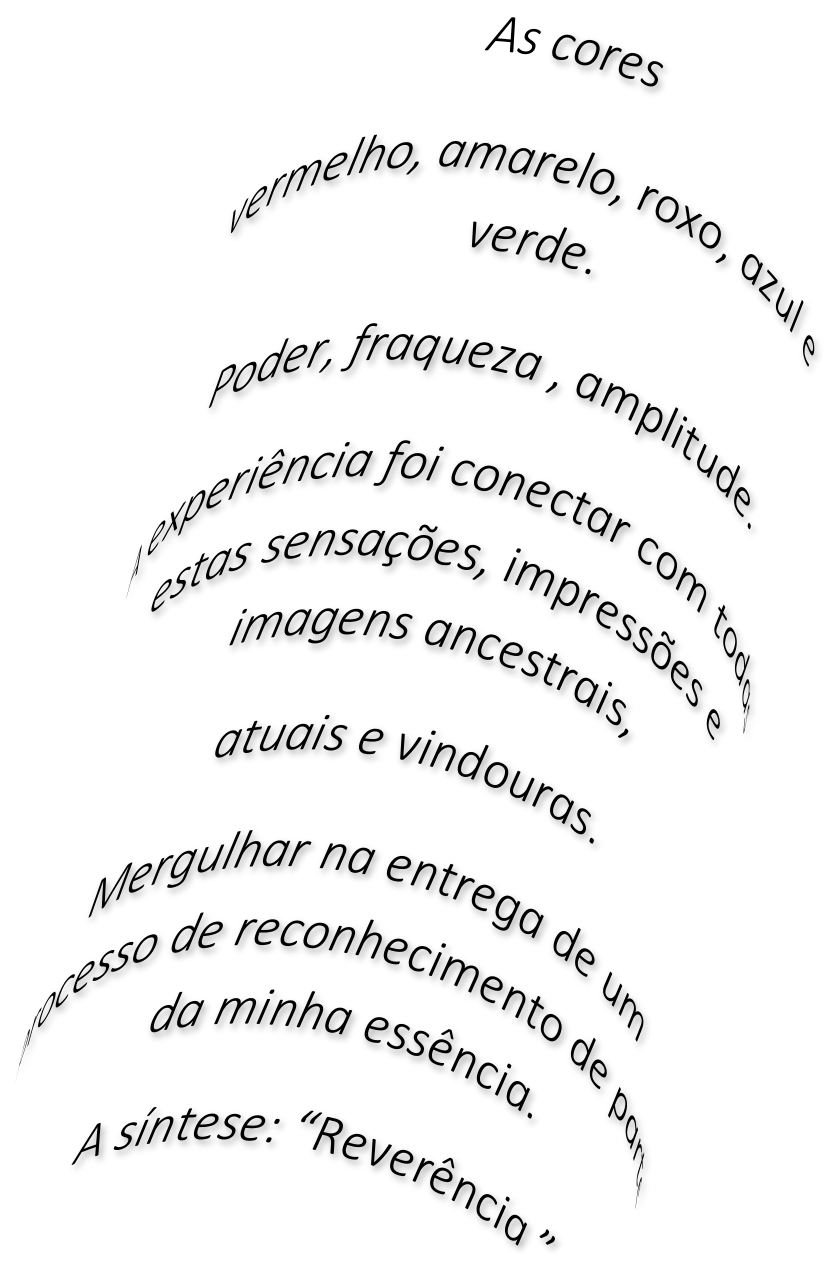


RELATO DO PAULO (O PINTOR)

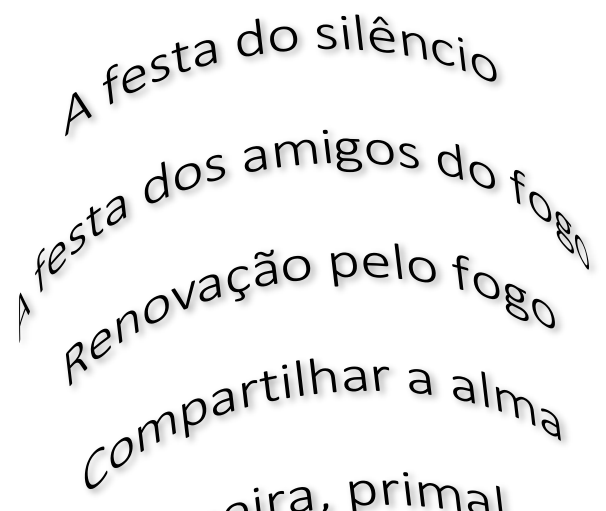
primeira, primal..

Nilagre da alquimia fogo, firmamento, universo infinito... $u^{d}$ dança com o fogo $v^{\nu^{\text {sitio Manto Azul. }}} \cdot 20$

195 
Local: Sítio Manto Azul

Horário: 20h40m

Carta do trabalho: Carta 36 - Seres do Trovão

Acendendo fogo: $22 \mathrm{~h} 25 \mathrm{~m}$

Câmera 1: Cláudia de Bem (pesquisadora). Carta 9 - Escudo do Sul

Lente: 70/20mm aberturas 2.8 macros

Câmera 2: Mário Carvalho (o guardião).

Lente: $24 \mathrm{~mm}$ abertura 2.8 planos aberto fixa

Câmera 3: Mário Carvalho (o guardião)

Lente: 24/105 $\mathrm{mm}$ abertura 4.0 móveis

Performer: Matheus Kleber (músico acordeonista). Carta 6 - Dança do Sol

Convidados:

Paulo (o pintor) Carta 26 - O Cocar

Raquel (antropóloga) Carta 13 - O Coral

Thais Petzhold (bailarina) Carta 5 - Povo em Pé

Carina (musicista) Carta 27 - O Berço 


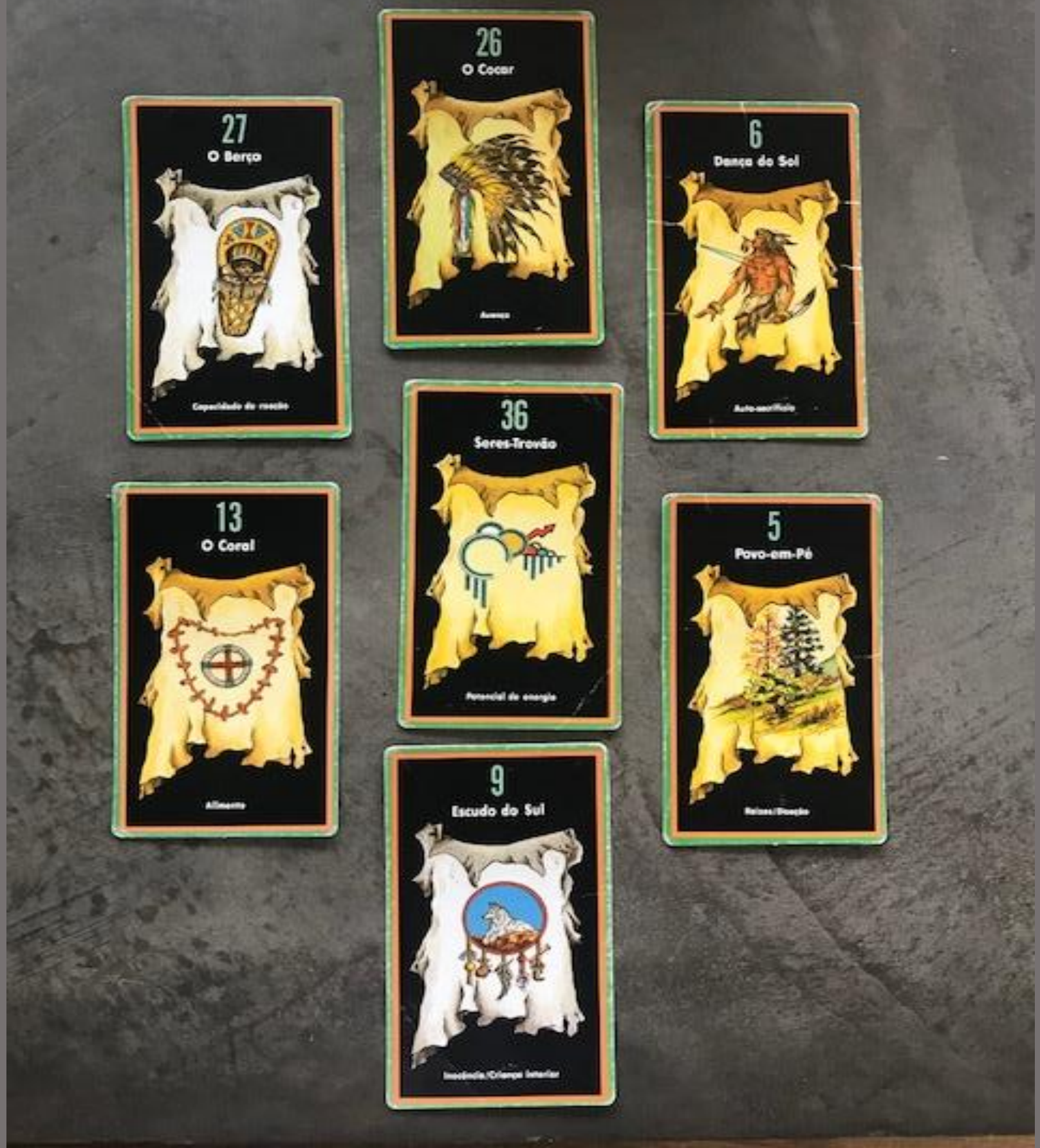






Crédito da foto: a autora 
Segundo dia de Manto Azul: pela manhã do dia 21 de janeiro, juntam-se a nós mais três convidados, Carina, Raquel e Matheus. Nós os recebemos impregnados da experiência da noite anterior, já retirados do mundo cotidiano. Foi das experiências em que reunimos o maior número de pessoas, nossa communitá cresceu e pela primeira vez teríamos como performer um músico, o acordeonista Matheus Kleber. Por esta razão a Carina Donida estava presente, amiga de longas datas, dona da propriedade manto Azul, musicista e produtora musical, e parceira neste projeto criando a sonoridade da vídeo-performance, que seria um desdobramento estético das hierofanias. Como a linguagem musical era a manifestação do performer, ela veio para captar a sonoridade da experiência. Por fim, acompanhando Matheus, havia Raquel, uma antropóloga pesquisadora e atuante em comunidades indígenas da etnia dos Guarani no Rio Grande do Sul. Ao todo, nossa communitá tinha sete componentes e nos preparávamos para mais um dia de trabalho coletivo em torno da nova experiência; mais uma fogueira a ser construída. Numa ação conjunta, fomos coletar material a quatorze mãos: gravetos, folhas e madeira para a montagem da fogueira. Pela experiência da noite anterior, tomei algumas precauções de segurança que passaram a ser incorporadas nas próximas práticas. Iniciei a montagem sozinha, no mesmo estado meditativo em torno das 15 horas, prevendo o início dos trabalhos para as 19h30. Todos tinham tarefas, Carina instalou um equipamento específico para captação do som, Mário ajustava as câmeras, Matheus, Paulo, Thais e Raquel auxiliavam em outras funções, como almoço e organização. Assim se criava a zona liminar 
onde vamos nos afastando daquele mundo cotidiano e entrando num estágio intermediário, o que Merleau-Ponty chamou de campo de presença. É como um rito de iniciação onde gradativamente vamos nos contagiando e construindo um estado em comum. Sem regras definidas, isso acontecia espontaneamente. Terminamos esta etapa à noite, lá pelas 20 horas. Ainda era necessário um tempo de isolamento para cada um se preparar para iniciar a experiência. Assessorada pelo guardião, tomei a iniciativa de deixar perto da fogueira um toco de madeira para que o músico pudesse sentar e apoiar o instrumento. Pelo menos, foi o que eu supus, mas não exatamente o que ocorreu.

Impossível não falar das estrelas desse dia. Era uma demonstração do infinito, da impermanência, poucas vezes vi o céu tão preenchido de brilho. uma imensidão que tirava o fôlego. Todos juntos, avistamos aquele céu num momento de contemplação, antes de iniciarmos os trabalhos, ali já sentia que estávamos interligados pelo cosmos. Nesse instante, em todas as experiências, eu era tomada por uma emoção, como um presságio. Sentia a presença de uma força que, apesar de nunca revelar ao grupo, tinha a potência de estabelecer o estágio preparatório em todo o coletivo, e o fato é que acontecia. São as camadas do invisível que se manifestam, e atribuo minha sensibilidade de perceber pelo estado preliminar das operações anteriores.

Já era noite e depois da benção estrelada, seguimos nosso rito: o oráculo, o cachimbo e as cartas.

As tochas foram acesas pelos quatro colaboradores: Thaís, Paulo, Raquel e Carina. 
O fogo surge no silêncio e o som vai preenchendo o espaço.

Antes de iniciarmos, Matheus me perguntou o que tocar. Eu respondi: Olha o fogo e deixa teu coração responder através do teu instrumento. Ele me fitou, não falou mais nada e se entregou ao fogo.

Admito que foi uma das experiências mais surpreendentes pois, em especial, o invisível se materializou de diferentes formas para todos. Eu enxergava através do meu olho transparente, o fogo se transfigurava em imagens de animais, seres e carrancas que pareciam surgir no interior da chama. Aquilo que alguns chamam de ilusão de ótica, para mim significava presenças. Também pensei na luz como a música na sua mais pura manifestação sonora, a melodia que nos toca e chega à alma, uma luz essencial.

Matheus em nenhum momento se sentou no banco, seu movimento era circular e variava entre contemplação e enfrentamento. $O$ instrumento era um prolongamento do seu corpo, e a melodia um grunhido, um dialeto, um idioma, uma comunicação visível entre o espaçamento das notas e o movimento do fogo. O olhar do performer era fixo e me chamou atenção a ponto de fazer um recorte macro com a lente. Um olho que aparentava um deslocamento para outra dimensão. Ali era possível ver um outro espaço que habitava entre ele, sua sonoridade e o fogo.

As certezas da percepção são algo muito maior do que podemos explicar, e o olhar de cada um traz mundos diferentes, tantas verdades, tantos saberes. Coexistíamos ali 
num coletivo e múltiplos olhares na experiência preenchidos de certezas sobre a arte como um lugar de pura intuição, de contemplação e de instabilidade.

No seu infinito, a noite das estrelas nos contaminou junto com o fogo, e outros mundos foram possíveis para nós ali, fora do limiar da visão profana.

Naquela noite, várias camadas se pronunciaram, o metafisico manifesto para cada um individualmente, e esse fato foi revelado na madrugada, quando compartilhamos nossas histórias invisíveis ao redor da fogueira.

Com a presença de Carina e de um equipamento sonoro mais sofisticado, gravamos nossas conversas ao fogo. O relato de Raquel tocou a todos. Notei que, ao nos agruparmos em volta da fogueira depois da performance, ela não se juntou a nós. Mais tarde, chegou enrolada num xale de cor, com os olhos brilhantes e em profundo silêncio; de pé, apenas nos ouvia. De repente, começou a narrar sua experiência - uma presença extrafísica de uma tribo indígena que, segundo ela, tinha sido dizimada e estava presa naquele lugar; havia sofrimento. Atraídas pela nossa experiência, pelo fogo e a sonoridade, se aproximaram buscando elevar seus espíritos para se libertarem daquela dor. Em detalhes ela narrou a performance daqueles corpos se arremessando no fogo e subindo em direção ao céu. Não posso afirmar a veracidade destas informações, muito menos questionar; aconteceu para ela e basta. Pelos outros depoimentos, que coadunam com este relato, ficam vestígios de que a manifestação extrafísica relatada por Raquel reverberou em todos nós. O relato do performer coincide com esse invisível e se juntam 
as imagens minhas e do Mário; e as batizei de criaturas do fogo. Nos registros fotográficos, até a chama teve uma performance diferenciada, muitas faíscas e um tom dourado, os seres do trovão já anunciados pelo oráculo comandaram naquela noite desde o céu de estrelas do início, e quando pensávamos que tudo se acalmava, uma luz despontou bem de madrugada para encerrar o ritual. Com todo o acontecimento, não consegui dormir; algo me inquietava, sentia que ainda estava em atividade, meu corpo estava estranho, tudo à flor da pele. Todos foram dormir, quase 5 da manhã, pois no outro dia, domingo, levantaríamos acampamento. Eu permaneci em vigília com aquela sensação esquisita no corpo; aos poucos, minha pele reagia com protuberâncias em áreas crescentes. Era como uma escama de lagarto, tudo em poucas horas. Assustada, chamei o guardião e todos foram acordando, surpresos com minha reação. De fato, foi tão forte que Mário resolveu me levar de volta para Porto Alegre, em busca de assistência médica. Saí às pressas deixando o coletivo e acabei o dia no pronto socorro. Até o médico se assustou e perguntou o que tinha acontecido, achei difícil explicar exatamente o que pensava ter ocorrido. Ele aplicou um antialérgico e disse que, pelo grau da contaminação, o medicamento levaria uma semana para agir. Fui para casa e dormi profundamente. Quando acordei, já não havia nenhuma marca na minha pele. 
\%

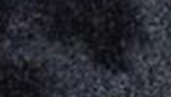

H.

W.

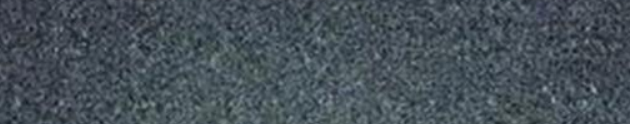

7.

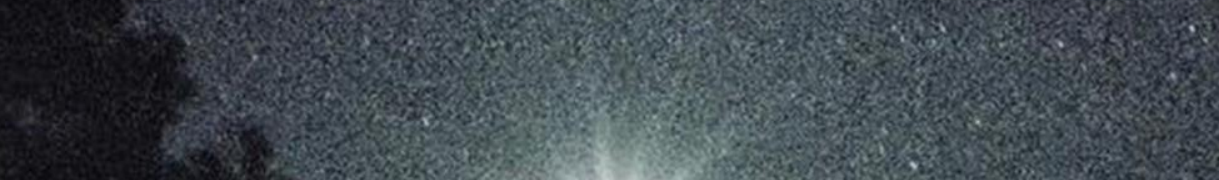
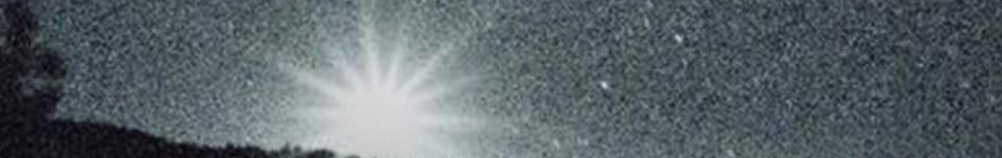

Shes

H.t.
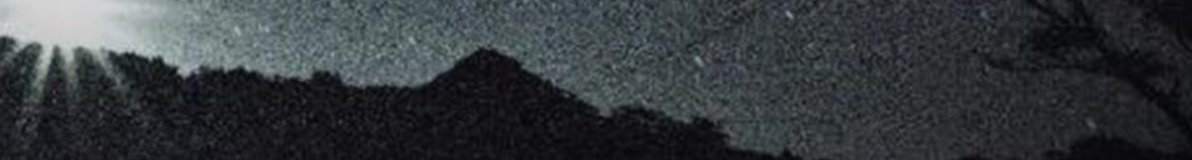


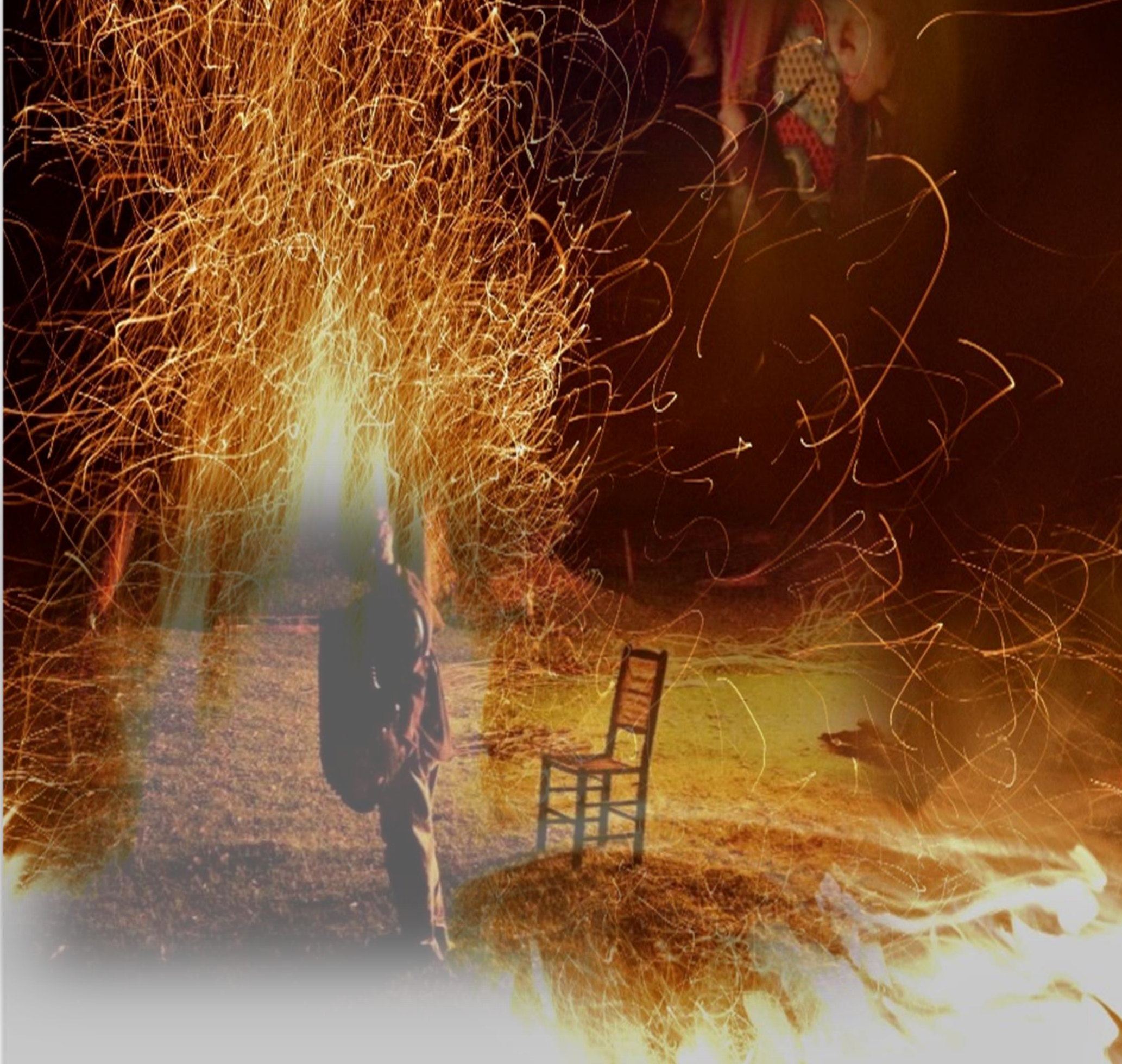




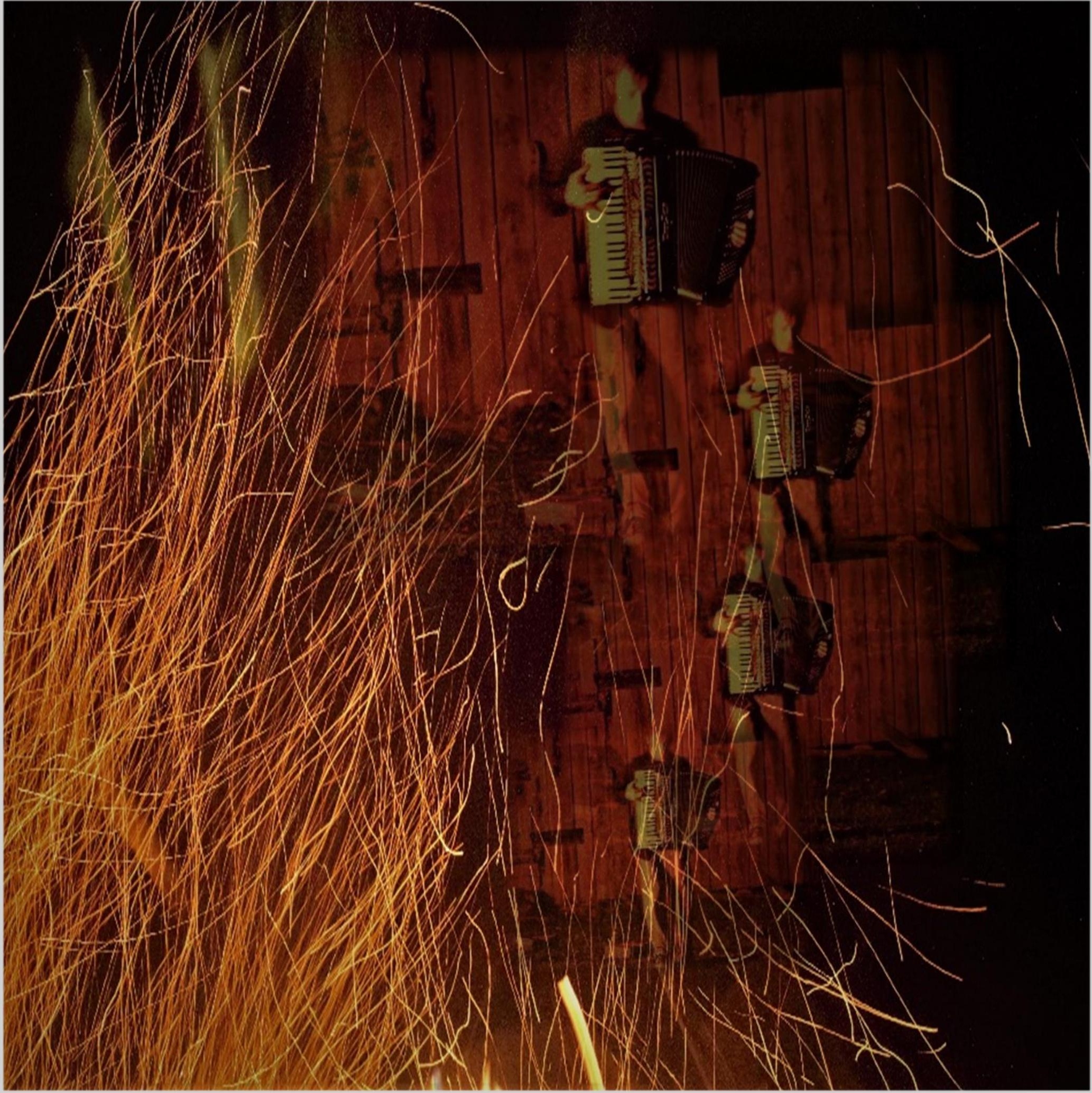




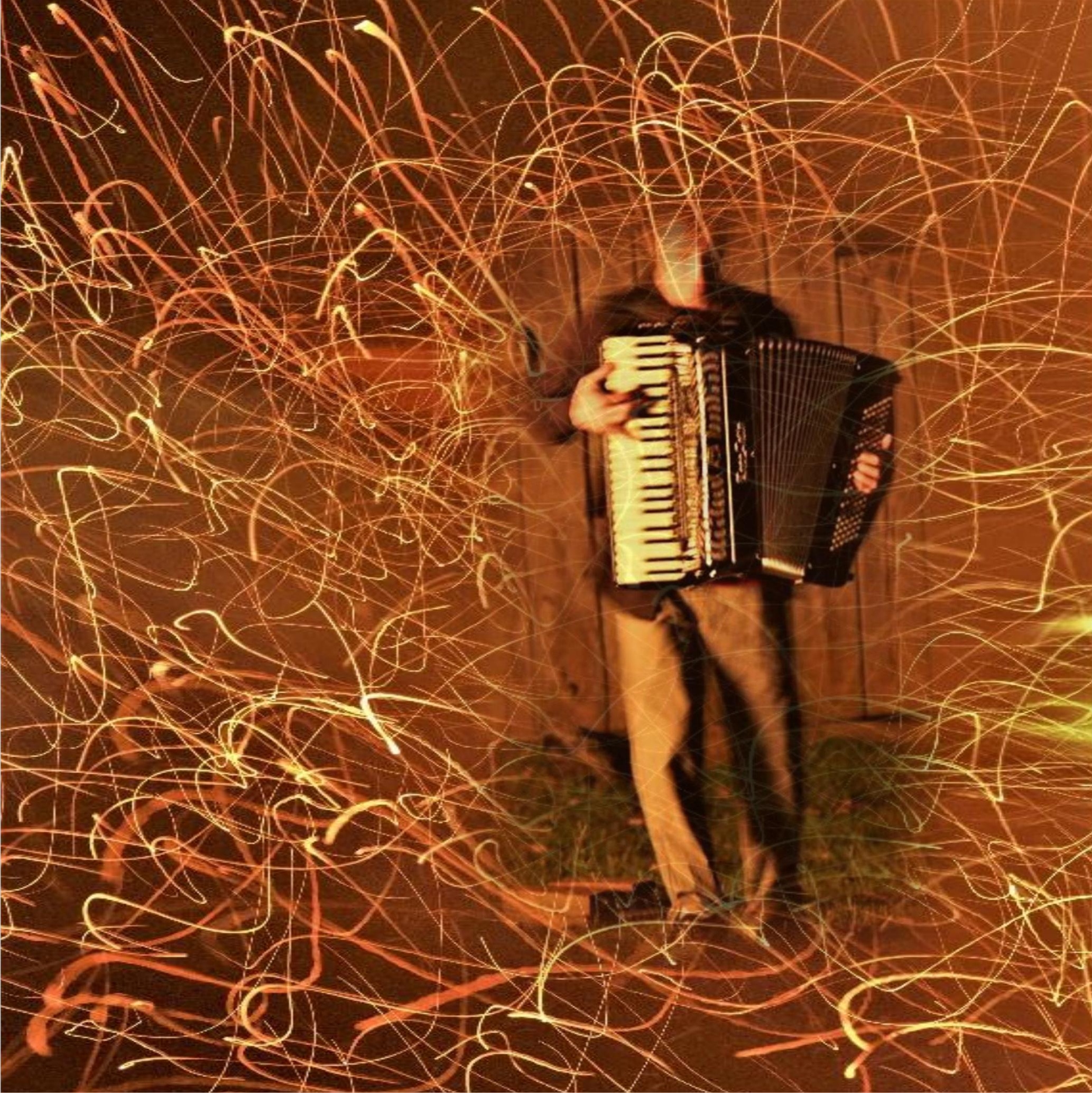




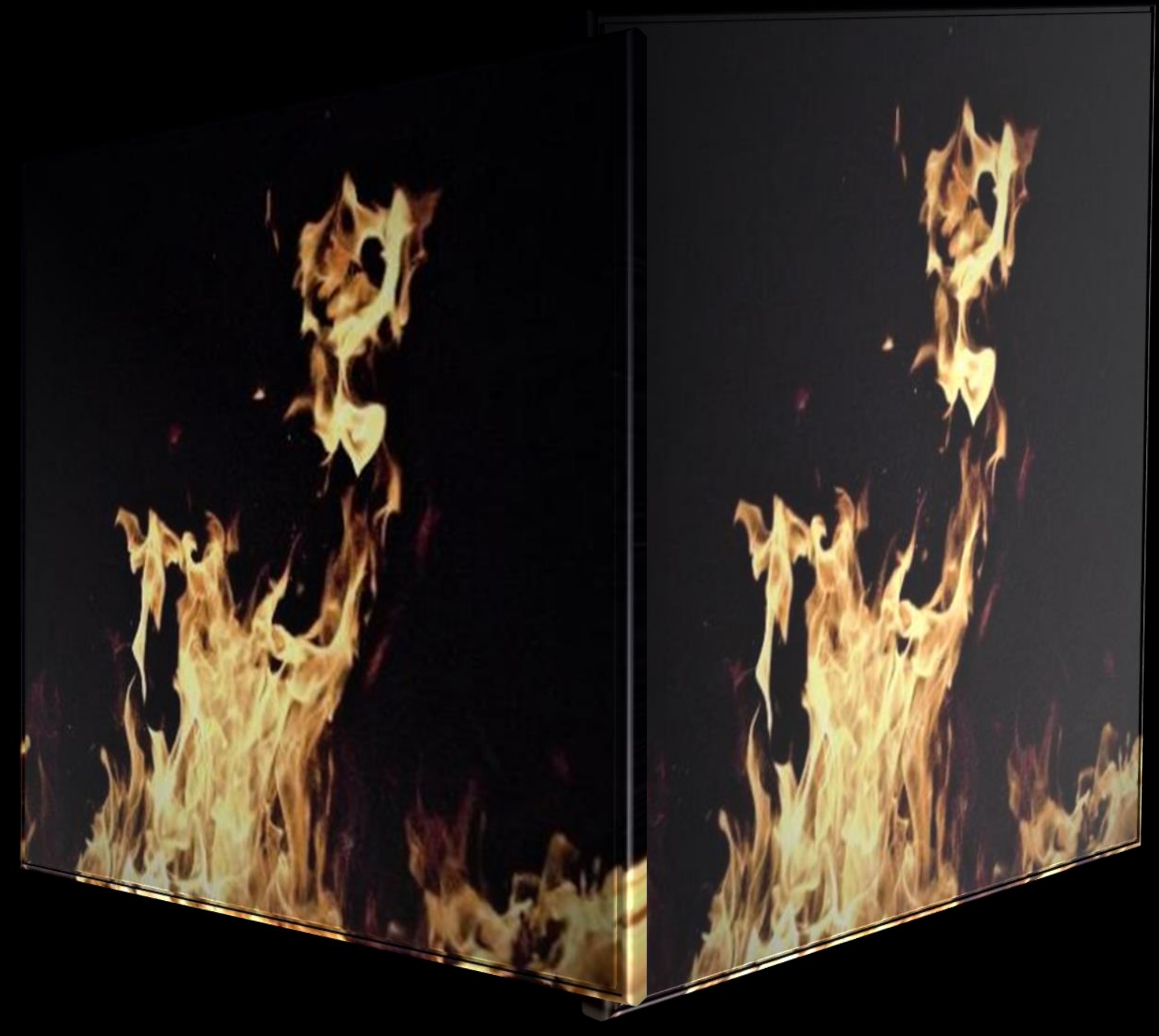




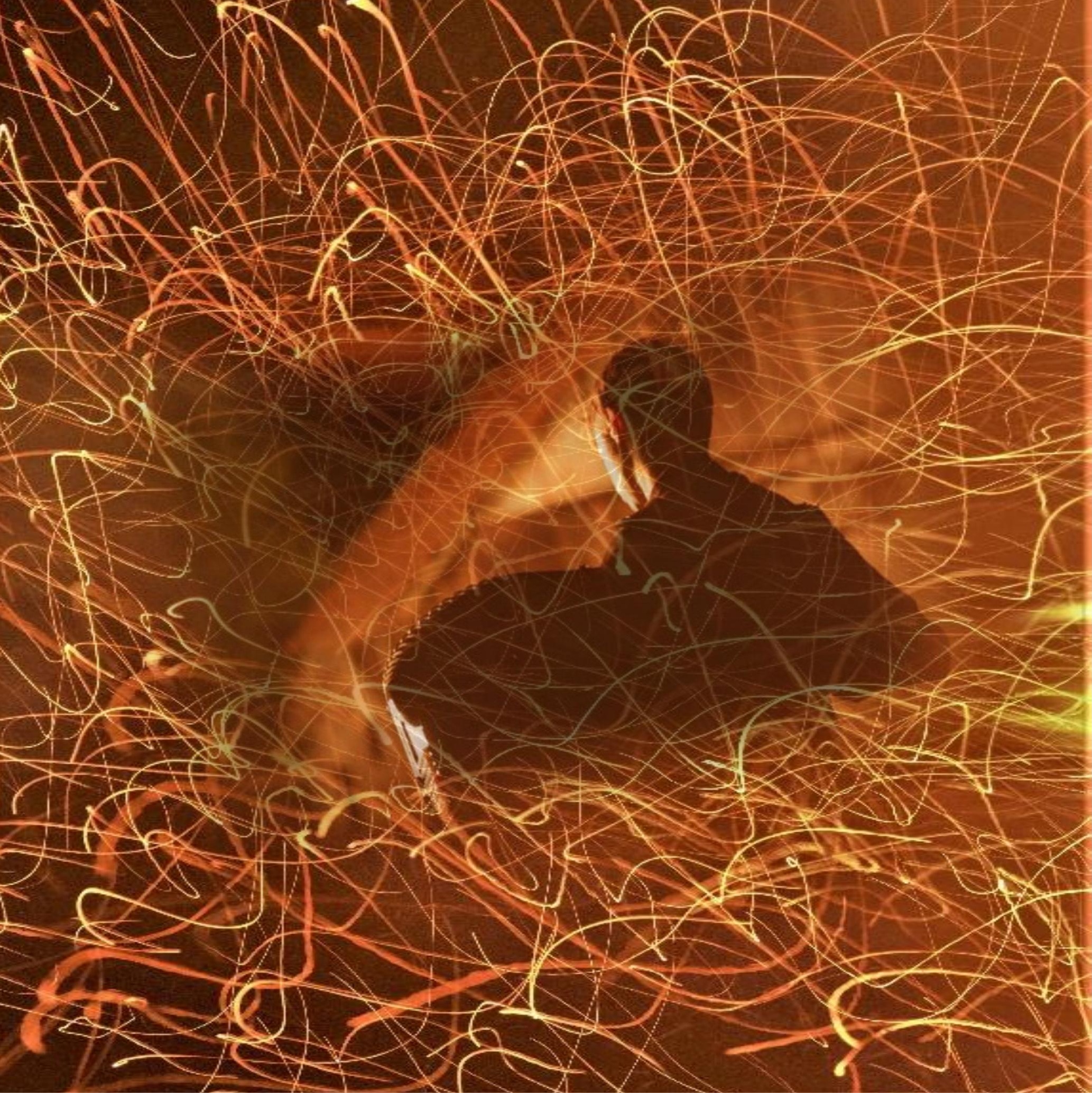




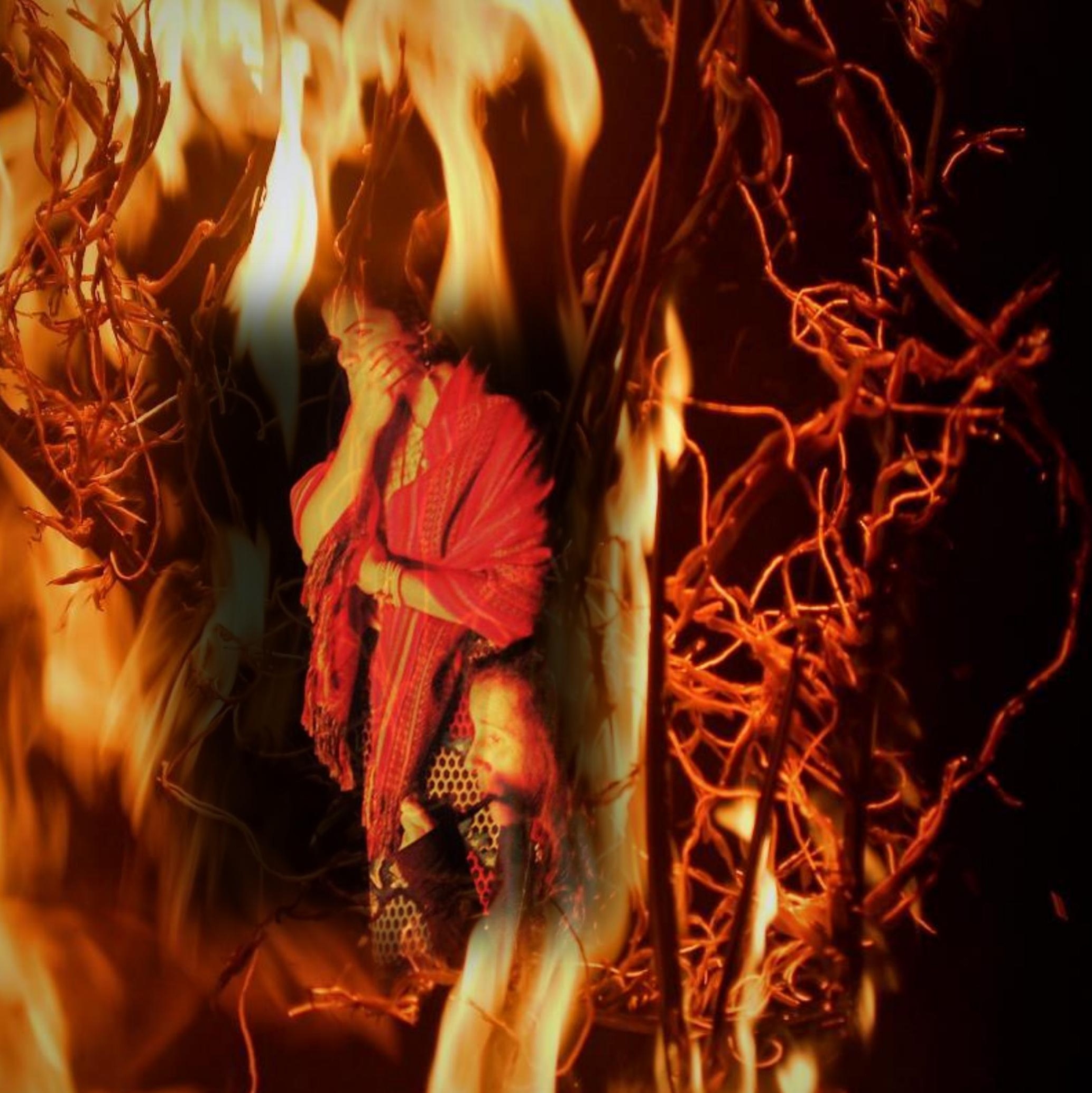





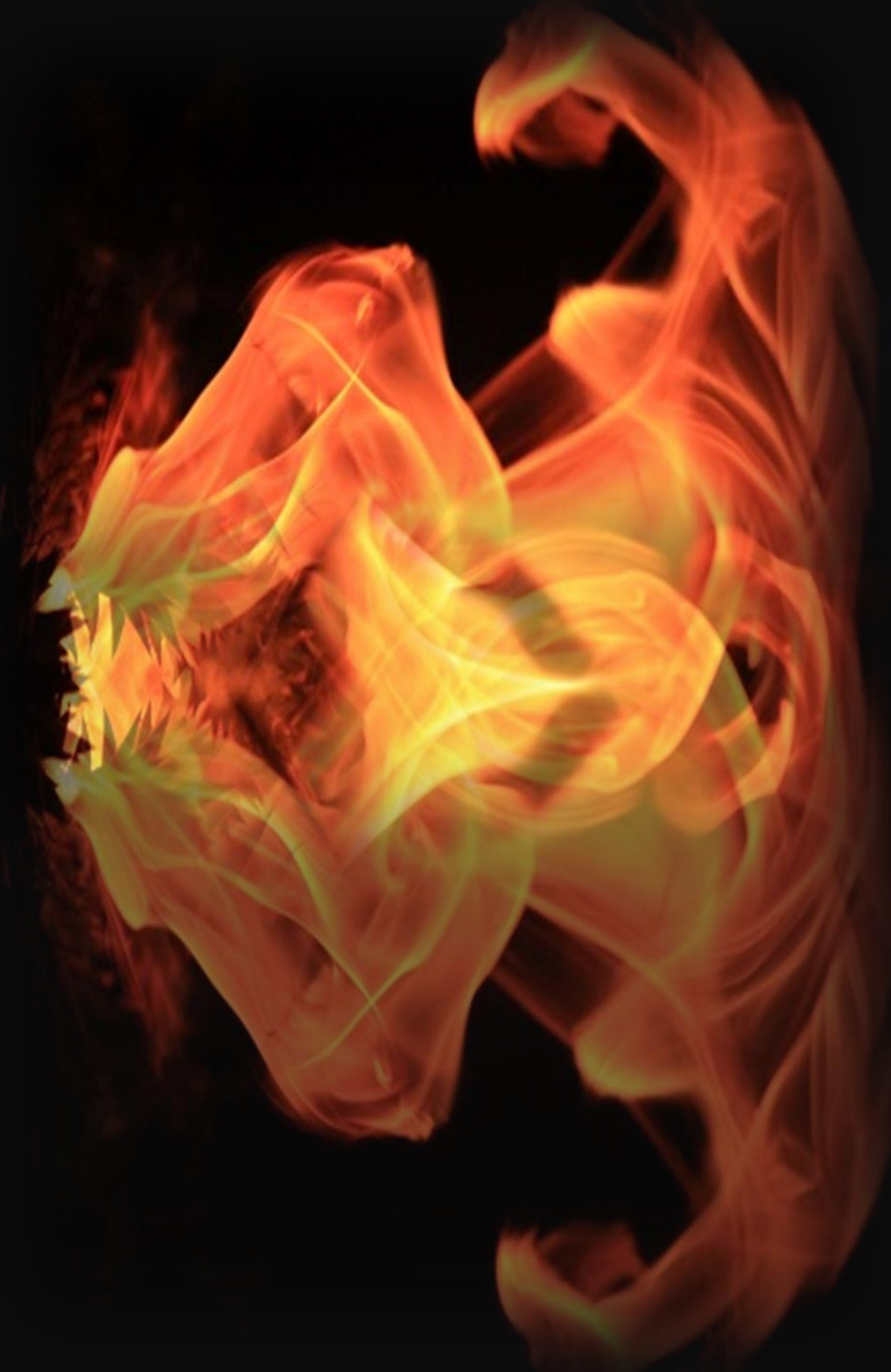




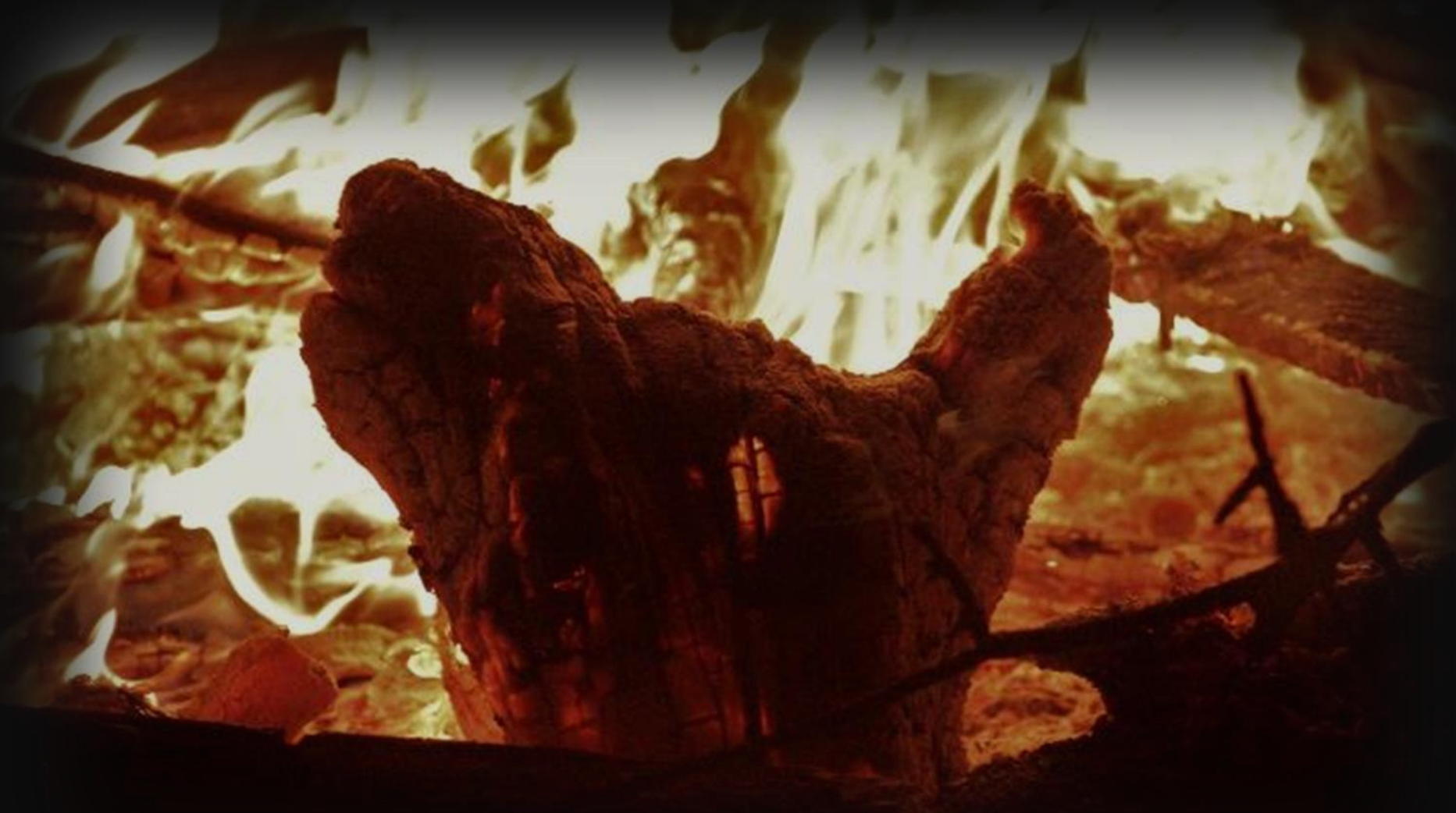






215 


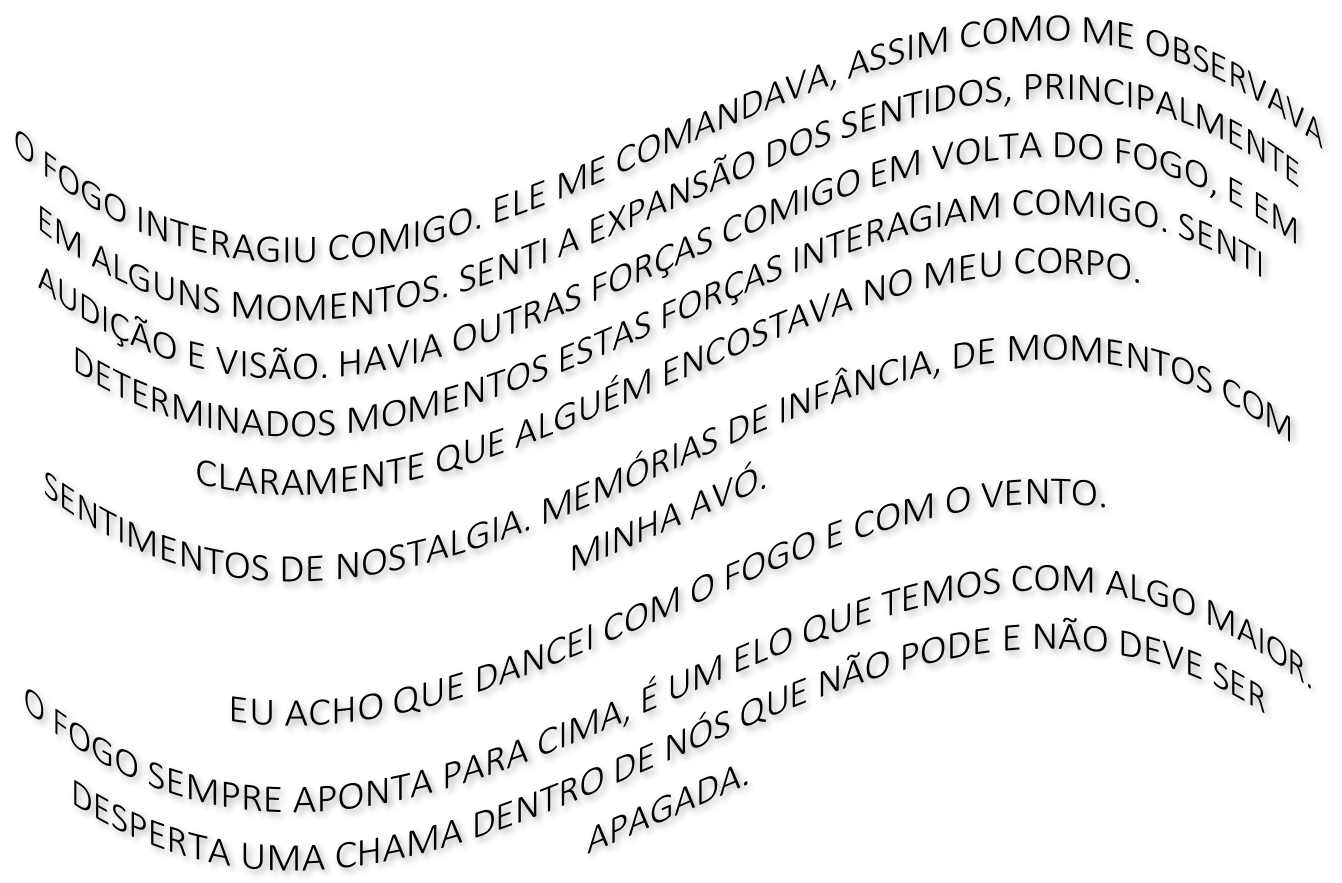


OSOM TEM PADROEES DE FREQUENCIA

FOl UMA EXPERIÊNCIA ÚNICA E INESQUECIVEL. ME FEZ RECORE ME RODEIAM, MAS PELL INSTRLNTRO DE MIM, NÃO SOMENTE PELAS PESOMENTO MOME, NAS DIVERSAS VEZES EM QUUE COMPARTILHEI A GRANDE MENTO (O ACORDEOM) QUE NA EXTO DO MEU COR COMELE.

INTIMIDADE QUE TE
217 


\section{Figura 7-Paulo de Araújo (desenho a lápis crayon)}




SÍTIO MOINHO VELHO

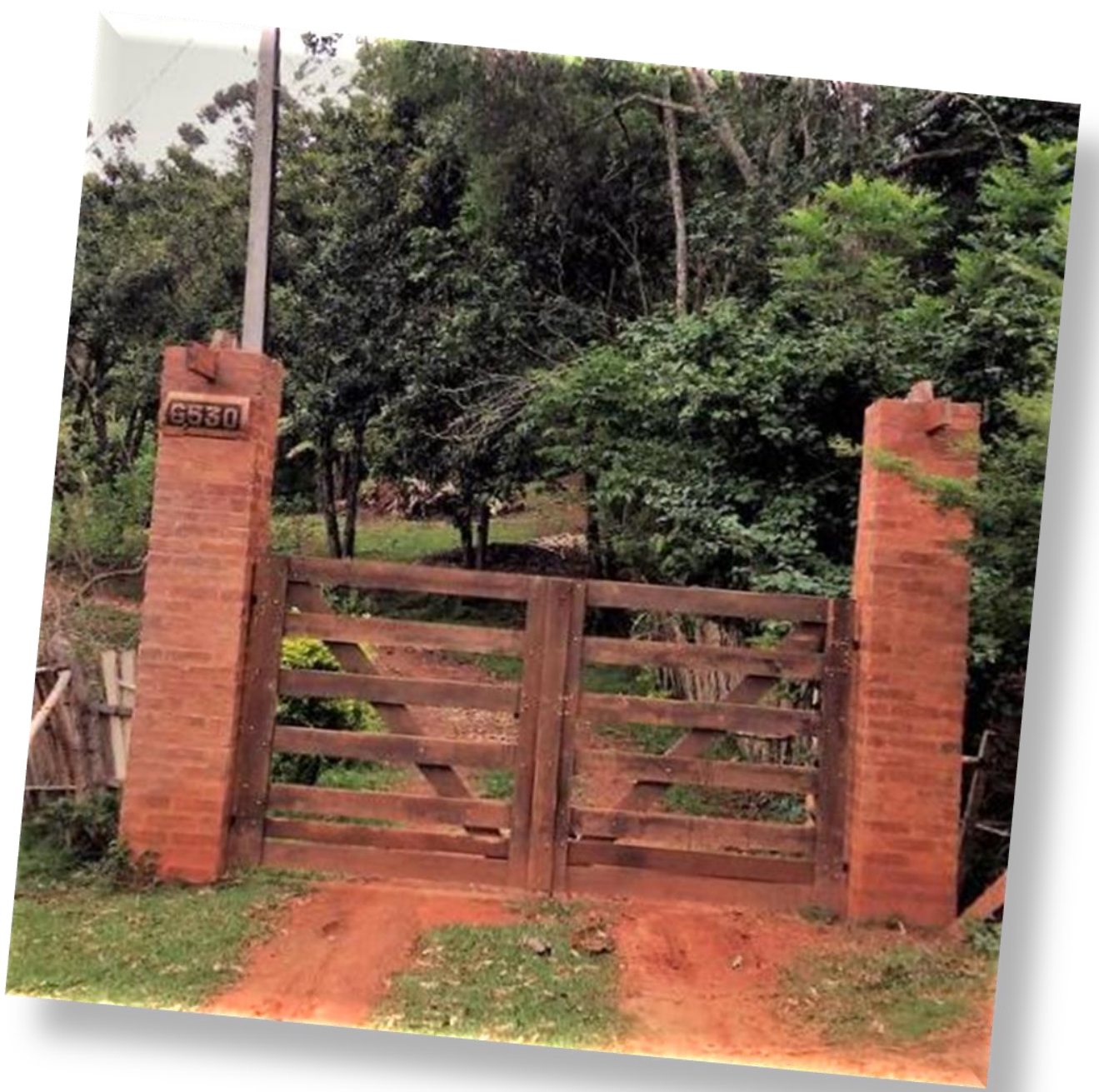


Localizado na zona rural de São Paulo, entre os municípios de Guaratinguetá e Cunha, Serra da Bocaina, a 240 quilômetros da capital está o Sítio Moinho Velho. Lá vive um amigo de longa data, o arquiteto e fotógrafo Marco Perez com sua companheira, a artista plástica Fernanda Valadares. Em 2017, eles estavam vivendo nesta propriedade que pertence ao pai de Fernanda para acompanhar uma obra arquitetônica sob responsabilidade do Marco, e ofereceram o espaço para minhas experiências. Aproveitei a oportunidade e convidei a Fernanda para realizar uma hierofania, pensando em ter o Marco para fazer o registro fotográfico. Seria maravilhoso, pois admiro muito seu trabalho.

O sítio fica numa região íngreme, com alguns indícios de vegetação de mata atlântica misturados à da Serra da Mantiqueira, apresentando uma área rochosa e montanhosa com araucárias e mata nativa. A casa fica numa ampla área plana, tudo bem estruturado, assim como os acessos para deslocamento. Havia vários recantos, um lago, trilhas, cavalos e outros animais de criação, como patos, galinhas de angola, cachorros. Cheguei no dia 27 de outubro de 2017 e permaneci até dia 01 de novembro.

Marco e Fernanda haviam se deslocado para o sítio, a princípio para ficar por um período, mas hoje eles residem lá por escolhas e aprendizados sobre as relações de vida, o espaço e a prática artística. Fernanda já imprimia na sua prática a relação de espaço e tempo, em que a percepção se ligava ao tempo real dos acontecimentos. Ela estava iniciando um projeto muito interessante: o "muda conversa". Eram 100 mudas da árvore Pecan que ela estava plantando. A ação artística envolvia plantar as mudas e associar a 
elas pessoas que haviam nutrido a própria Fernanda de alguma maneira durante a vida. Com o tempo ela faria as relações entre o crescimento das árvores, a artista e as pessoas. Próximo de cada Pecan colocava um pequeno bloco de madeira com o nome da pessoa. Ganhei minha árvore e, com o passar do tempo, pedia notícias dela. Em 2018 retornei ao sítio para mais uma hierofania. Eu estava atravessando um período muito delicado de stress emocional pela perda da minha mãe, ocorrida no início daquele ano. Quando perguntei a Fernanda sobre minha árvore, ela falou com tristeza que resistia, mas com muita dificuldade. Naquela ocasião eu a visitei e senti nela parte de mim. Compartilhei este relato com Fernanda que, até então, não sabia da minha perda. Cuidamos de reforçar a minha Pecan para que ela pudesse continuar a nos dar respostas. Hoje, em 2020, sei que ela está forte e robusta, resistindo aos tempos pós modernos.

Marco, diferente da Fernanda, teve outra relação com a mudança para a vida rural. Ele é um arquiteto primoroso, todas as suas edificações são sofisticadas esteticamente, seu conflito está em viver com as tensões do mundo urbano. Sua permanência ali como artista, na minha percepção, gerou uma produção de imagens do deslumbre da natureza. Acompanho seu espaço virtual e é como se tivesse notícias diárias dele.

Quando cheguei, conversamos sobre tudo, inclusive meus objetivos artísticos que vinha compartilhar com eles, e sobre as necessidades físicas e materiais para executar as práticas. Eles me concederam uma grande quantidade de lenha que tinham em estoque, e isso tem a ver com o Marco, pois elas já estavam guardadas, organizadas por tamanho e 
espessura. Pensei que teríamos uma escultura simétrica. Nessa hierofania, experimentei um novo formato de fogueira, pensando em corrigir as falhas das anteriores. No outro dia, saí em busca do espaço e encontrei uma área onde havia uma estrutura de concreto, como uma churrasqueira antiga. Em frente, uma parte mais plana, adequada para atuação. O que me ocorreu se refere aos planos de imagem: se eu tivesse uma fonte de luz mais alta ao fundo, a segunda fogueira, o contra luz, construiria uma relação de profundidade da imagem, e ao mesmo tempo um reforço do corpo do performer. Outra questão foi encontrar alguma estrutura plana para não queimar o solo. Como eles estavam em obras, cederam umas telhas de zinco grandes que seriam trocadas. Eu já via um outro desenho que fugia do círculo e caminhava para uma forma mais retangular; pareceu interessante. Todas estas decisões estavam apenas comigo, Marco e Fernanda estavam muito comprometidos com a obra. Eu os deixei à vontade e eles a mim. A experiência só aconteceria no outro dia, então tive mais tempo de experimentar. Foi como aqueles dias em que temos mais tempo no teatro para montagem, e nos dedicamos a estudar o espaço, as estruturas cenográficas, a maquinaria cênica e a construção do desenho. Dediquei este dia a organização e coleta do material orgânico disponível na mata, bem diferente do Moinho Velho. Palhas, folhas secas de paineira, e encontrei folhas de palmeira, imensas, e as reservei para alimentar o fogo durante a performance, pensando na plasticidade das imagens que poderiam gerar. Nessa construção já havia um pensamento estético sobre luz e imagem: a visualidade da performance. 
No outro dia, fui ao espaço e comecei a construir a nova forma. Em alguns momentos em que retornei à casa, observei que a Fernanda preparava alguns objetos, possivelmente para a performance. Eu já havia mostrado o espaço e conversamos pouco sobre a prática. Sempre tive esse cuidado metodológico de não expor nenhuma experiência anterior, me interessava a ação espontânea que viesse da relação fogo e corpo. As informações eram precisas com relação à área de atuação, devido ao enquadramento da câmera. Isto agora era mais rígido pois estava apenas com uma, e não poderia correr riscos de perder o registro da performance. De todas, creio ter sido a minha melhor escultura. A fogueira principal se assemelhava a um barco Viking no meu imaginário; depois, com a queima, isto ficou mais evidente. Nos encontramos no final da tarde e expus as ações preparatórias, oráculo, tochas, o caderno de anotações e os códigos para entendimento da finalização. Este código eu sempre deixava para o performer decidir, era importante apenas que existisse entre nós. Independentemente de qualquer problema técnico, como acabar a bateria, este código era respeitado. Marco veio fotografar e Fernanda trazia consigo vários objetos que acomodou no espaço. As tochas, sempre quatro, seriam acesas por nós três, e eu ficaria responsável por dois pontos. A segunda fogueira seria acesa no segundo momento por mim e Marco. Nunca expliquei sobre estes procedimentos ritualísticos; entendia que isto também dizia respeito à percepção de cada um, e não desejava nenhuma imposição sobre a atmosfera, o que foi importante naquele dia, pois pressenti um distanciamento por parte deles. 
Data:31/10/2017

Local: Sítio Moinho Velho

Município: Cunha/SP

Carta do trabalho: Carta 4 - Cerimônia do Peiote

Acendendo fogo: $18 \mathrm{~h} 34 \mathrm{~min}$

Final do trabalho: 21h13min

Câmera 1. Cláudia de Bem (pesquisadora)

Lente: 70/20mm aberturas 2.8 macros

Performer: Fernanda Valadares

Colaborador: Marco Perez

Animais:

Cão (cachorro )

Tuca (cachorro)

Mira (pato) 


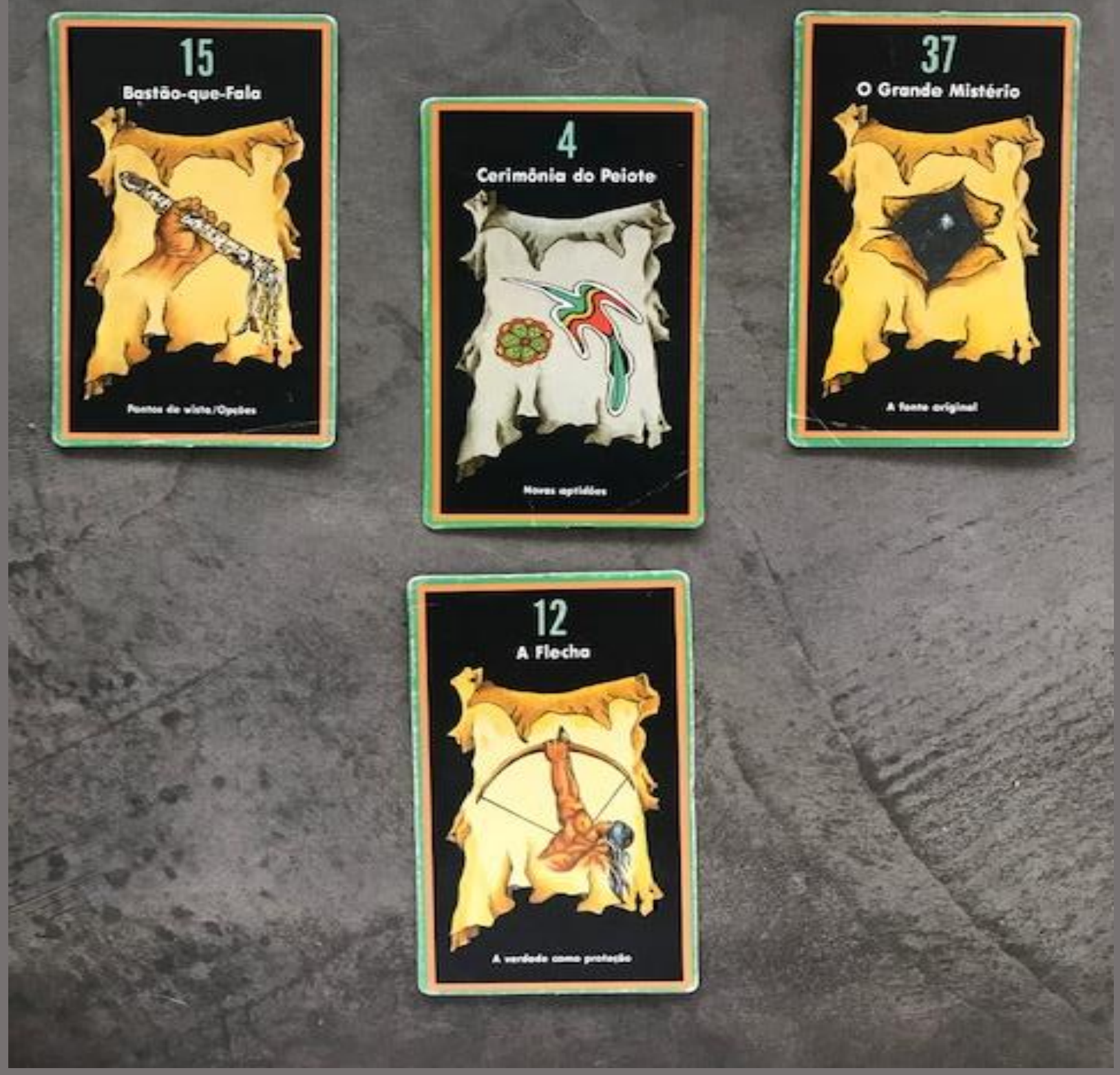




\section{O ORÁCULO}

A CERIMÔNIA DO PEIOTE

QUANDO O ESPÍRITO DO POVO SE ROMPEU QUANDO O BÚFALO DEIXOU DE VAGUEAR

QUANDO TODAS AS NOSSAS TERRAS FORMAM TOMADAS

E NÓS NÃO TÍNHAMOS CASA

O REFLEXO DO PÁSSARO DA ÁGUA DOS UNIVERSOS INTERIORES

NOS INDICOU NOVAS APTIDÕES

E NOS TROUXE DE VOLTA A ESPERANÇA 


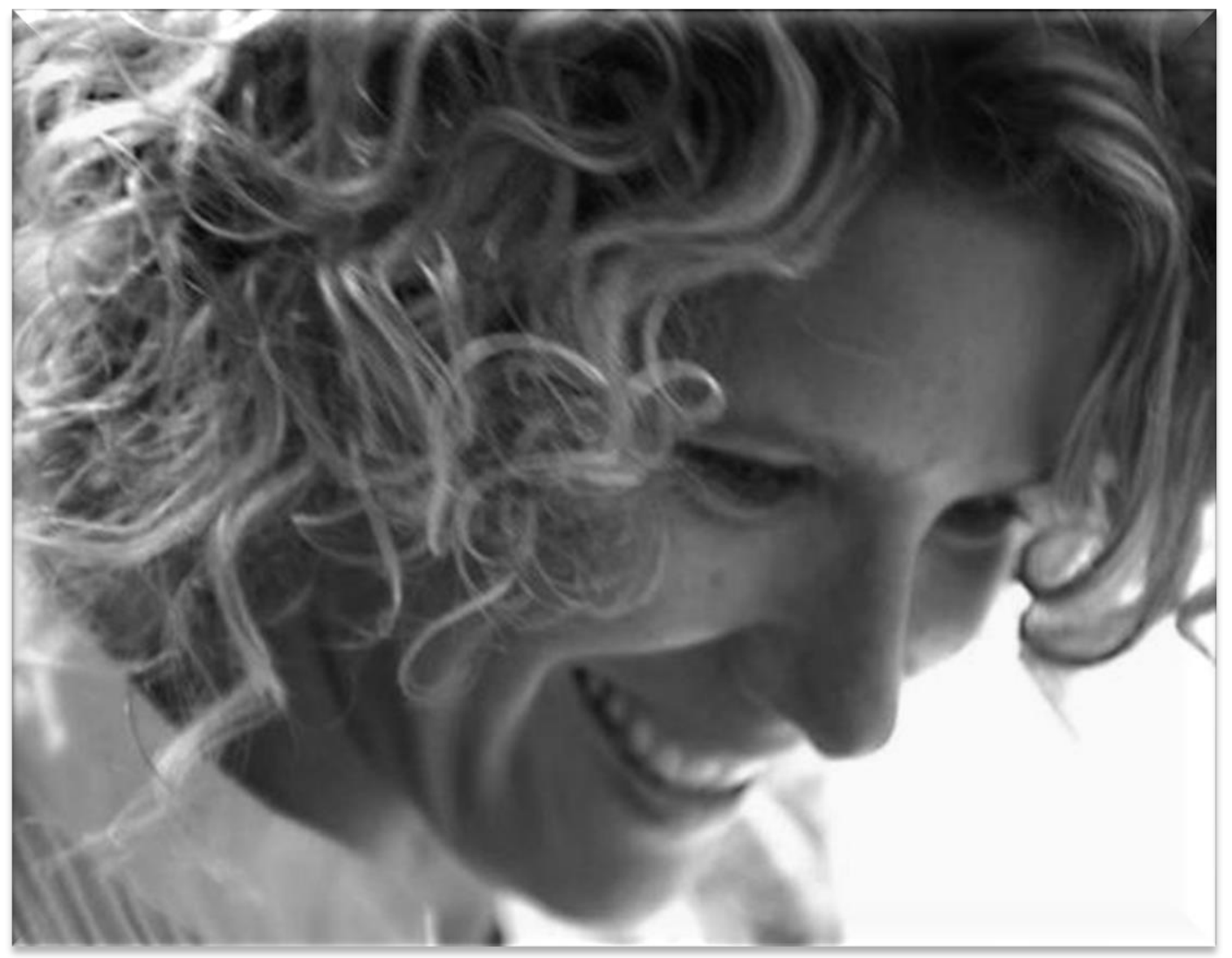

Crédito da foto: Marco Perez 
Acendemos os fogos, e o Barco Viking tomou conta do espaço em segundos. A simetria da fogueira em todas as camadas fez com que o fogo se espalhasse no espaço de forma simétrica e com consistência material pela quantidade de lenha maciça. A presença da segunda fogueira deu uma perspectiva ao corpo, e parecia que ele estava dentro do fogo. Esteticamente foi o trabalho mais bonito em imagem e plasticidade. Fernanda iniciou a performance com uma venda e uma túnica longa, preta. A força da imagem era maior que a atuação da performer. Digo isto porque o que eu via na câmera era diferente do que acontecia. As imagens remetiam à inquisição, mulheres pegando fogo e a venda significando aprisionamento. Quando me detinha no acontecimento, o que via era uma proposta de ação anteriormente construída, o que foi bem interessante no decorrer do trabalho. O mais fascinante desta manifestação da luz é o poder de atuação e imposição sobre nós. Frente ao fogo, onde temos um espaço restrito de ação, é ele que impõe o movimento, pois o calor e o risco nos fazem agir. Quando ela entrou com os olhos vendados, pela força e intensidade da chama, era impossível sustentar um deslocamento ou ação específica. É difícil ter noção de distanciamento seguro sem a visão, os outros sentidos se aguçam e o risco aumenta. Então, ao entrar no espaço, a sensação era de um corpo em chamas aos meus olhos, para ela talvez estivesse no corpo. Ela imediatamente se sentou, e depois em alguns instantes retirou a venda. O fogo estava muito intenso e não havia o que fazer. Fernanda buscou seus objetos de performance que faziam sentido para ela no período preparatório e que pertenciam a seu repertório 
imaginário, como panos, uma bacia de pedras, um estandarte vermelho, e agia com suas propostas. O que eu percebia era o elemento desestruturando estas ações, um duelo entre o desejo da performer e o obstáculo do fogo. Ele parecia sempre vencer. Esta ação de resistência tomava outro significado para a performance, o fogo como inquisidor e dominante, seu caráter explosivo e incendiário, e um corpo em enfrentamento. Os deslocamentos foram de entrada e saída sem tréguas até o momento em que senti desistência e retirada conforme o código estabelecido. Depois, já distante e fora da ação, ela se colocou frente a ele numa posição mais meditativa; na narrativa que eu havia construído, parecia haver frustração. Ao acabar o trabalho, sempre solicitava que o performer escrevesse algo como registro que eu lia somente dias depois. Já em São Paulo, quando encontrei as poucas palavras de Fernanda, refleti acerca das várias impressões sobre um acontecimento, e deduzi que a imagem que eu captava naquele dia era significativa para mim, a ponto de me fazer criar uma narrativa para ela.

O trabalho foi muito bonito e revelador, novas formas, enquadramentos e imagens. Também a nova forma encontrada foi reproduzida posteriormente, em março de 2018, quando retornei ao Sítio Moinho Velho para mais duas hierofanias. Encerramos aquela noite com o fogo no forno de barro, onde o Marco assou pizzas acompanhadas de uma boa taça de vinho.

As fotos são dos olhos mágicos de Marco Perez. 


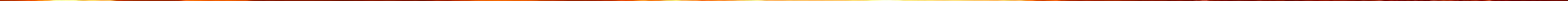









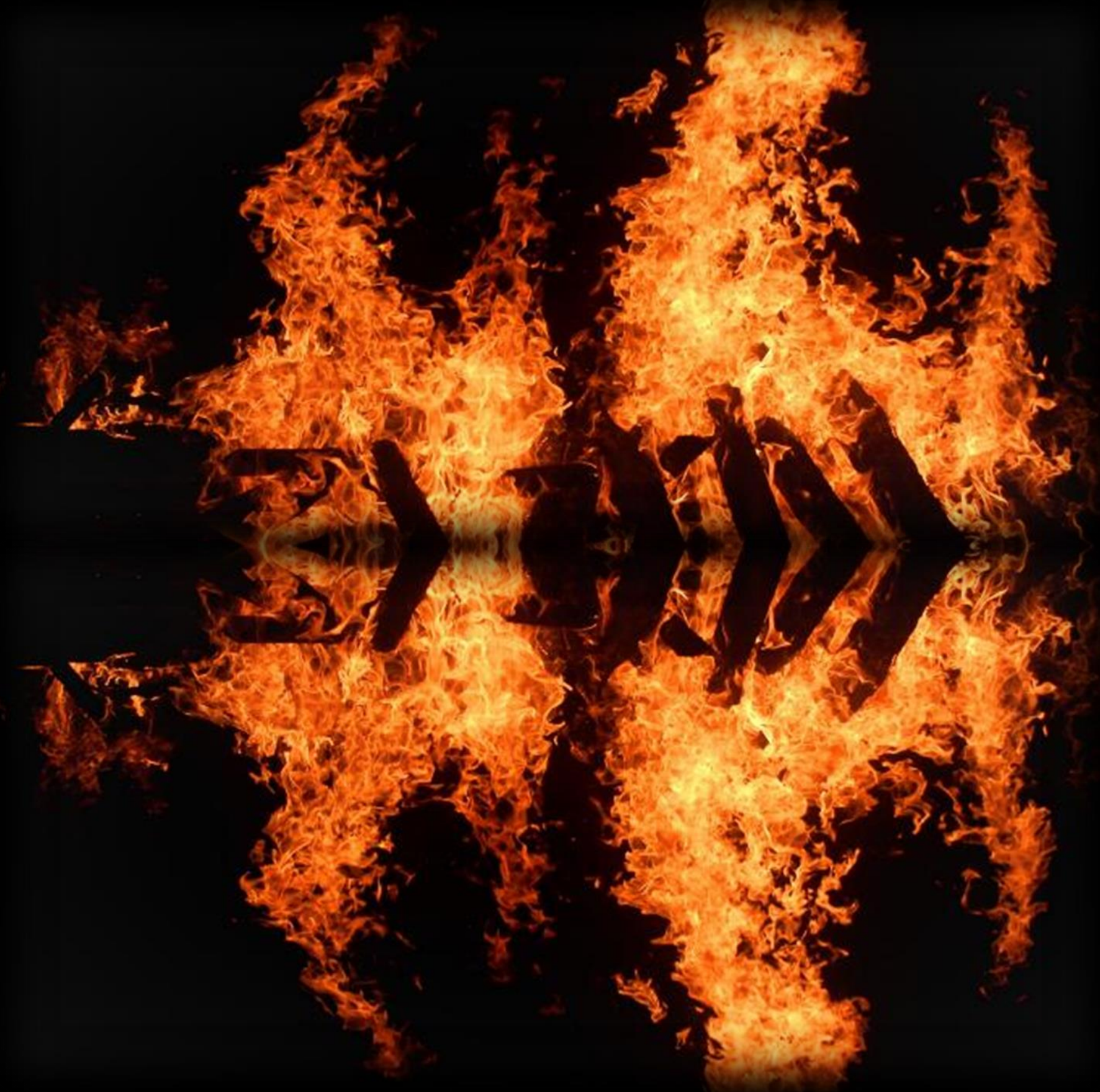


RELATOS DA PERFORMER

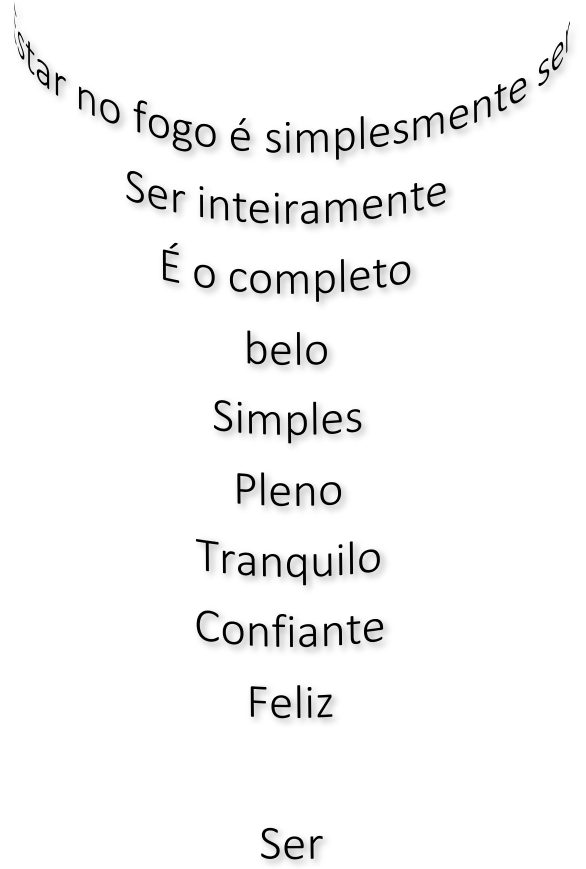

235 
Escute a melodia de olhos fechados, pensando apenas nela, não justapondo mais sobre o papel ou sobre um teclado imaginário as notas que concebeis assim uma pela outra, que aceitam então tornar simultâneas $e$ renunciam à continuidade de fluidez no tempo para se congelar no espaço; encontrareis individida, indivisivel, a melodia ou a porção da melodia que tiveres recolocado na duração pura. Ora, nossa duração interior, encarada do primeiro ao último momento da vida consciente, é alguma coisa como essa melodia. Nossa atenção pode se desviar dela e consequentemente da sua invisibilidade; mas, quando tentamos separar, é como se passássemos bruscamente uma lâmina de uma chama: dividimos apenas o espaço ocupado por ela. Quando assistimos a um movimento muito rápido, como de uma estrela cadente, distinguimos muito nitidamente a linha do fogo, divisível à vontade, da indivisivel mobilidade que ela subentende: é esta mobilidade que é pura duração.

$$
\text { -BERGSON 1972, p.102 }
$$


Por alguns meses concedi uma pausa ao olhar, fazendo alusão ao pensamento de Bergson em relação à pura duração como um mergulho profundo ao interior e a sua afirmação de que o real só pode ser compreendido pelo homem pela intuição da duração. Um fechar dos olhos para o que realmente é a constituição do real, privilegiando o que é superficial na observação dos fenômenos. É nesta mobilidade que encontro a pura duração com a luz, e consigo, na sua presença, materializar em experiência poética, sensorial e filosófica, permitindo que o imaginário se construa não como um ato apenas cognitivo, mas como uma interferência invisível ampliando meus canais perceptivos.

Depois desta hierofania, achei que deveria mergulhar sozinha na experiência, permitir visitar meu olhar sob a mesma ótica sugerida aos performers, seguindo os mesmos rituais já estabelecidos. Depois de cinco meses, em abril de 2018, logo após a falecimento de minha mãe, parti com minha câmera, um tripé e duas lentes para o Sítio Moinho Velho, onde me aguardavam Marco e Fernanda com outras perspectivas sobre suas vidas naquele lugar. Eu estava pronta para duas experiências, a minha e outra com uma amiga musicista, Ana Eliza, que chegaria dois dias depois. Seriam duas fogueiras em quatro dias, muito trabalho. Cheguei à tarde e eles já haviam feito alguns preparativos, contando que o espaço já tinha sido eleito como o canto do fogo. E assim foi. Regressei exatamente ao mesmo lugar em que havia parado. Desta vez seria somente eu.

Portanto, o que segue se interliga com a minha experiência, meus devaneios... Escutar a melodia do fogo... 


\section{HIEROFANIA 4 - O Confronto}

Data: 09/04/2018

Local: Sítio Moinho Velho

Município: Cunha/SP

Carta do trabalho: 30 - O Fogo Sagrado

Acendendo fogo: $18 \mathrm{~h} 40 \mathrm{~m}$

Final do trabalho: $21 \mathrm{~h} 45 \mathrm{~m}$

Câmera 1. Cláudia de Bem (pesquisadora)

Lente: 70/20mm aberturas 2.8 macros

Convidado: Axita (o cão)

Cumpri todos os estágios. Meu barco Viking junto com meu luto. Esperando o sol se ir. A carta guia era o Fogo Sagrado, e foi o que me guiou. 


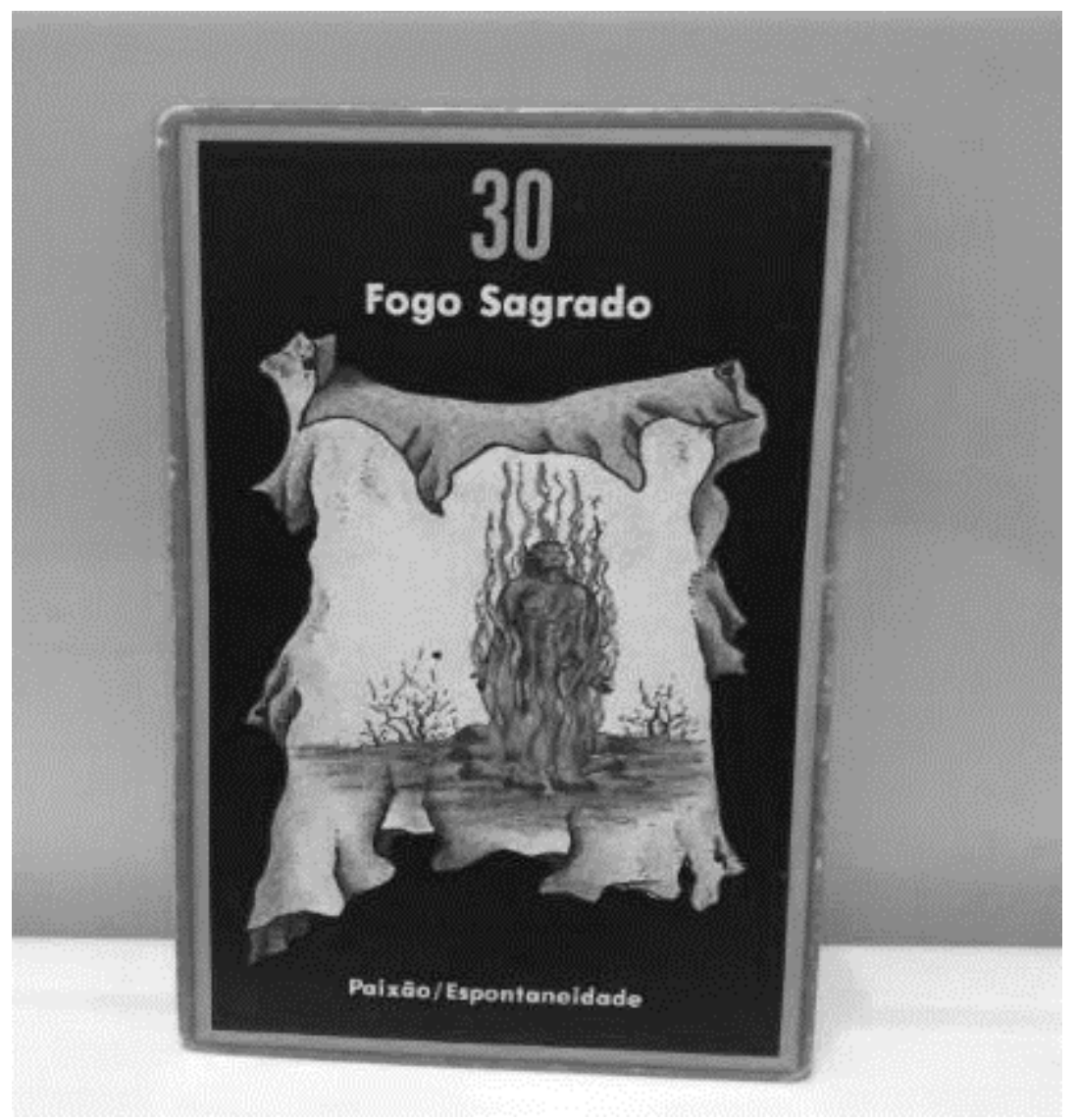




\section{ORÁCULO}

FOGO SAGRADO DENTRO DE NÓS

LUGAR DE CHAMA ETERNA,

QUEIMA E AFASTA AS BARREIRAS

TRANSMITE-NOS O CALOR,

A BONDADE

E O AMOR DO AVÔ SOL

DERRETENDO TODAS AS DIFERENÇAS

PARA QUE NOS TORNEMOS

FINALMENTE UM!

só 
PERFORMER: CLÁUDIA DE BEM

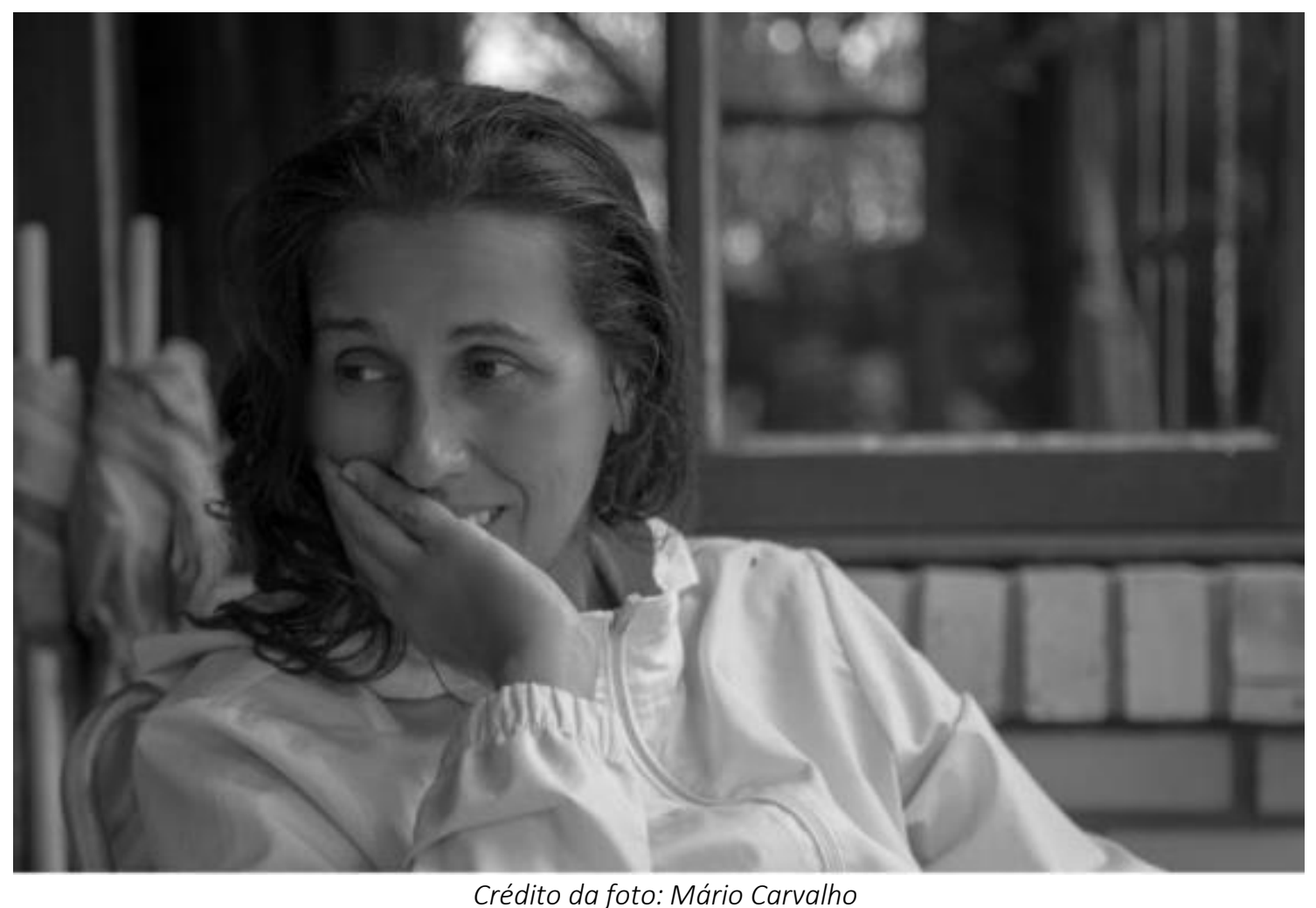


Agora, neste exato momento, entre a espera e a escuta, me preparo para acender o fogo. Um labirinto habita dentro de mim, tão grande e longo que qualquer atalho é inútil. Ao centro uma possível chama, alta, vibrante. Preciso entrar no labirinto. A luz existe ali, no centro, ao redor de mim. Entre nós o percurso. Difícil saber a dimensão deste espaçamento, talvez quilômetros de milímetros, não importa. Um espaço insólito, enigmático, irregular e sinuoso é a morada deste profundo silêncio, insuportável e também confortador.

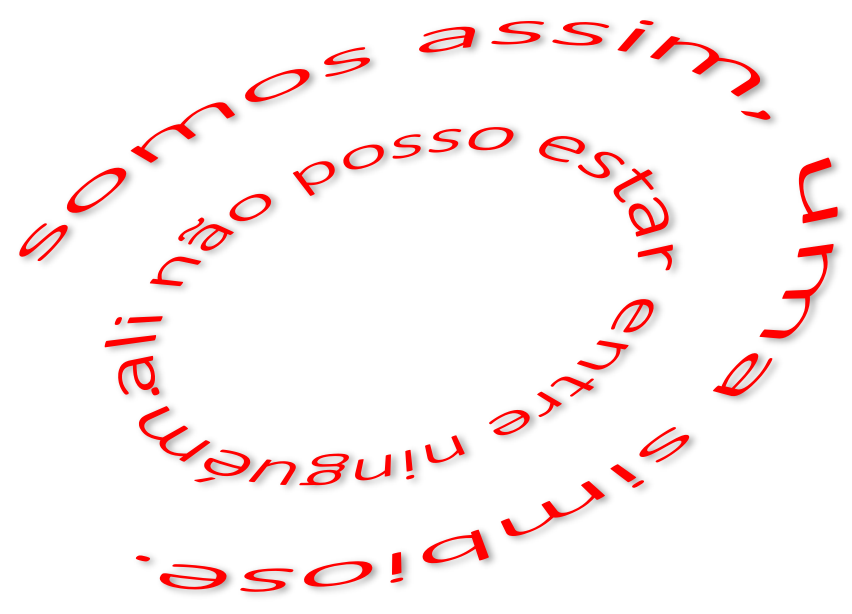

Dividida pela instabilidade comunicável entre os espaços, me aproximo com restrita mobilidade corporal, num estado entre o gasoso e o líquido para criar uma forma entre a matéria e o espírito. O tempo é um sopro contínuo e de insignificantes horas. 
Fecho os olhos e aguardo a chegada do vazio, o espaçamento entre nós parte de mim, do meu imaginário à espera do preenchimento.

Neste instante construo a imagem: uma mesa, uma vela, o cachimbo na boca, o mantra ao longe. Eu procuro o centro e esta é a verdade. O maior labirinto é aquele que construí dentro de mim, além do meu complexo tímpano. Preciso entrar para compreender a prática, o fogo, o xamã. Disseram muitas vezes que eu era feiticeira, mas não acreditei. Hoje elas me chegam de canto e me entregam receitas de poções. Entre a luz e a sombra, a mulher e o fogo, uma empatia, uma semelhança com estas personas liminares que dominam os poderes da natureza. Somos de fato bruxas e alquimistas nesta jornada da luz. Uma energia nos conecta com a matéria, e no entre estar nas coisas existe um mar envolto em raios. Resgato algo dos filósofos da natureza, uma memória secular, um pensamento sobre o existir no cosmos.

Um poder natural, a dimensão sem medida, os metros que não têm centímetros, os quilômetros não feitos de metros, a linha do horizonte distante, uma passagem do tempo, uma espiral, hipnose. O tempo é rápido e transparente, não existe uma única forma. O corpo é o que tem de mais sólido. Penso no limite que impomos a nossa ação artística ao observar o fogo. Ele age com fluidez, dispensa críticas, desbrava o espaço, sem limites. Eu recuo e reverencio.

A inquietude do elemento, suas formas, rebeldia, uma luz incontrolável de temperatura, intensidade, movimento, ângulo, ritmo. O corpo se move em direção à luz, 
um movimento de avanço e recuo. Quem determina este ir e vir? Com poder hipnótico, evoca inspiração, epifania, presença e abstrações. Com uma rapidez não lógica, o olhar inventa uma sequência de formas luminosas. São carrancas, animais, texturas e objetos manifestando-se naquele espaço.

Numa partitura de rompantes labaredas à brasa contida, a luz multifacetada se exibe num som que vibra, explode, acalma, silencia. Algo que no corpo se sente, do ardor à quietude, do ímpeto à serenidade. Um fluxo vermelho que é azul, às vezes amarelo, verde, e por instantes ausência da cor. Assim transitamos por seu espectro em que a cor inexistente é preenchida pelos sentidos. Eu sou o

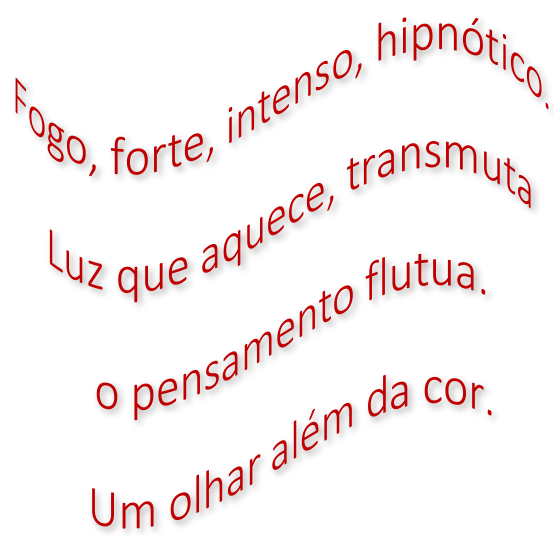
elemento, ele me representa no instante em que o reconheço. As imagens que visitam a poética são descritas por várias linguagens. A palavra adormece e se espreguiça, e a narrativa das imagens invade as margens das folhas e se esparrama no papel, subvertendo linha e métrica. A palavra é luz. Tudo arde em algum lugar.

A luz assume um significado de regresso, encontro e presença. Travestida de chama, escultura viva natural e orgânica, desprovida de adereços, ela dança. A experiência poética está em transcender a linguagem e acessar os atos poéticos ali representados pelo elemento. A primeira reação do corpo foi de estagnação, qualquer ato ou movimento 
parecia não ser natural. Talvez a ação mais espontânea fosse simplesmente olhar, mirar aquela dança para consagrar a experiência, dançar com os olhos. A condição humana desta vivência, o transcender o tempo, o estar de fato entre as coisas e coexistir nelas nos eleva à dimensão sagrada da relação corpo-natureza. Neste estado de presença, encontro potência, sensação de pertencimento. Talvez seja a arte ou a luz que vejo... Eu a vi e ela me avistou de um lugar em que não havia estado. Ela é meu próprio olhar no limiar da minha visão entre profano e sagrado em que presencio a aura.

Não tenho ao certo o que me fez parar, talvez a chama já baixa tenha sido a referência do tempo cronológico.

Quando retornei, meus dóceis anfitriões me aguardavam com honras saborosas. Dormi profundamente. Existia uma outra fogueira a ser feita para Ana Eliza. 



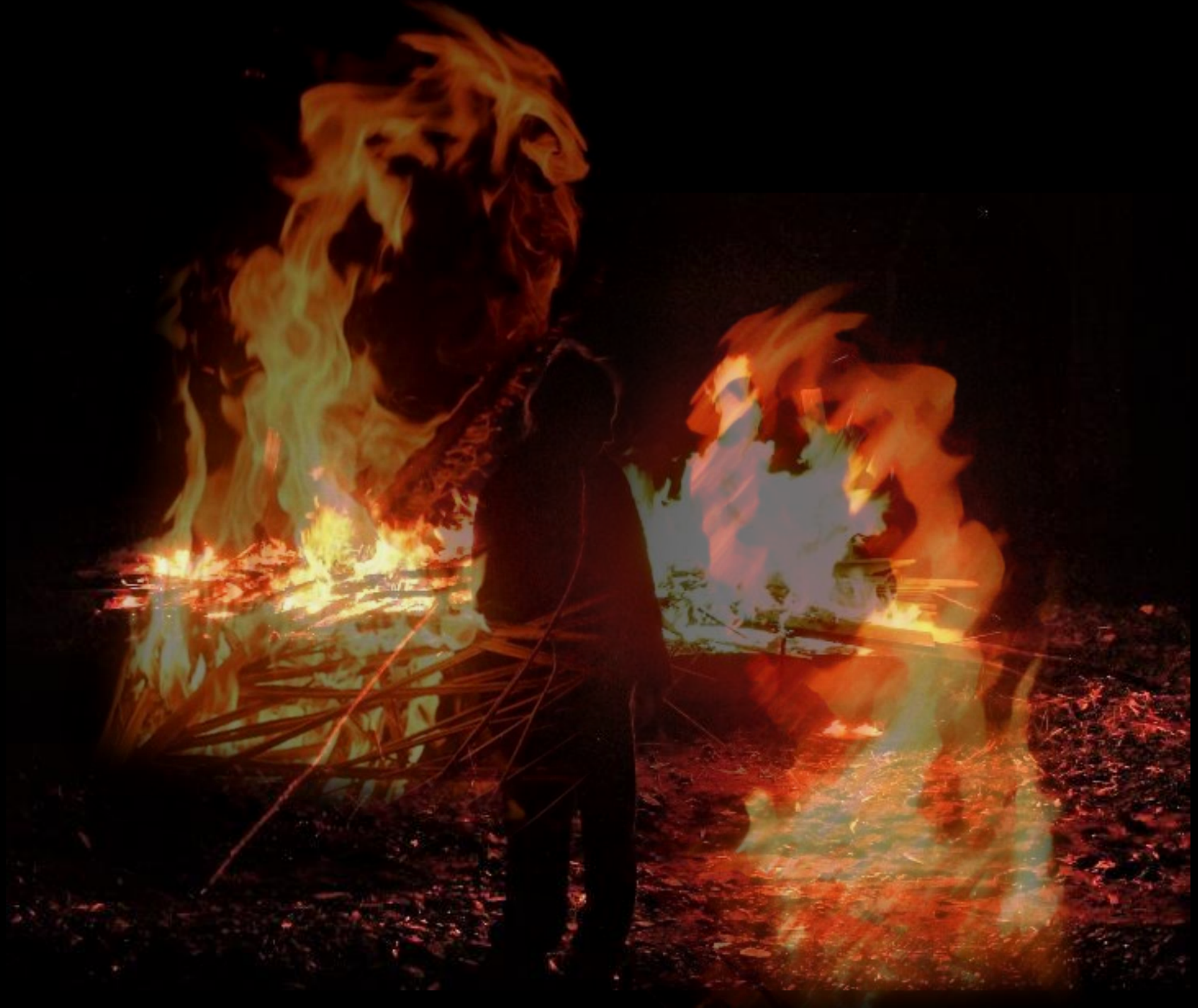



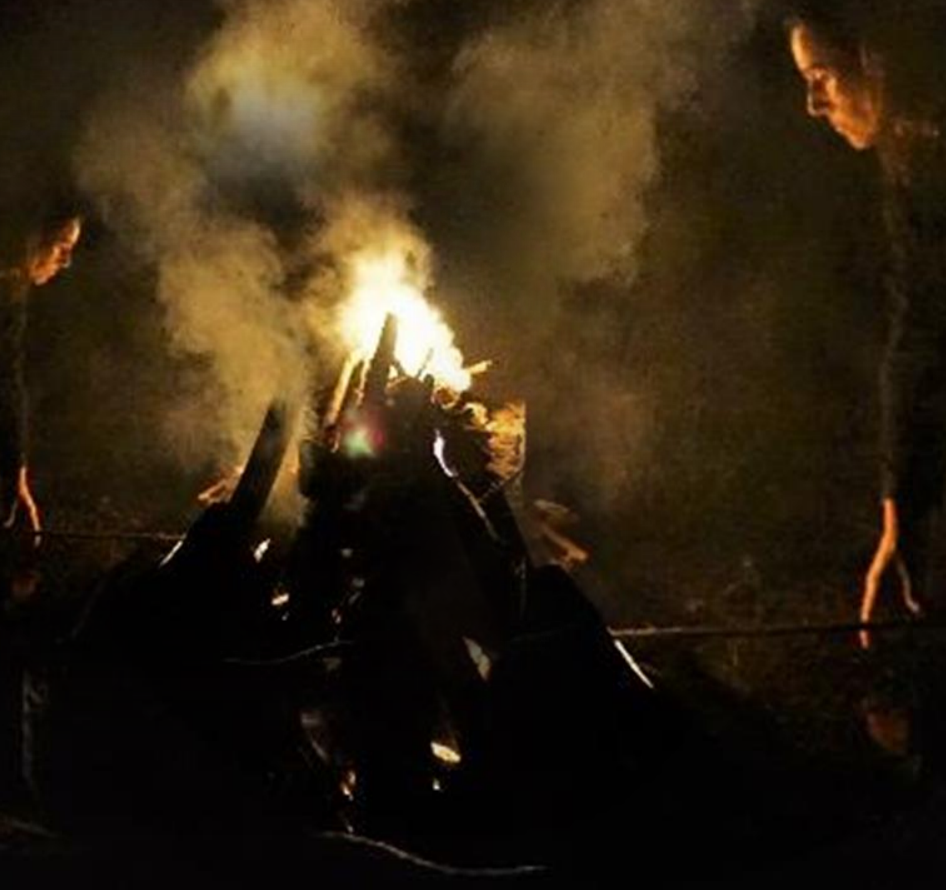

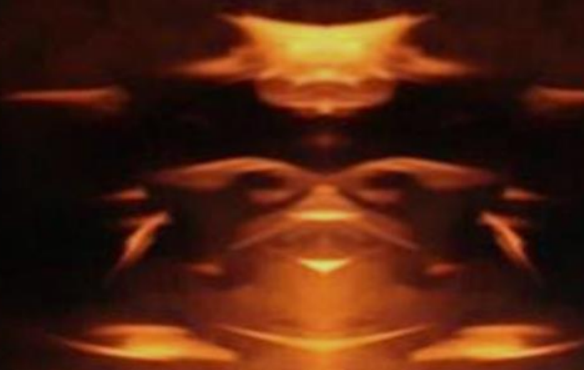

1
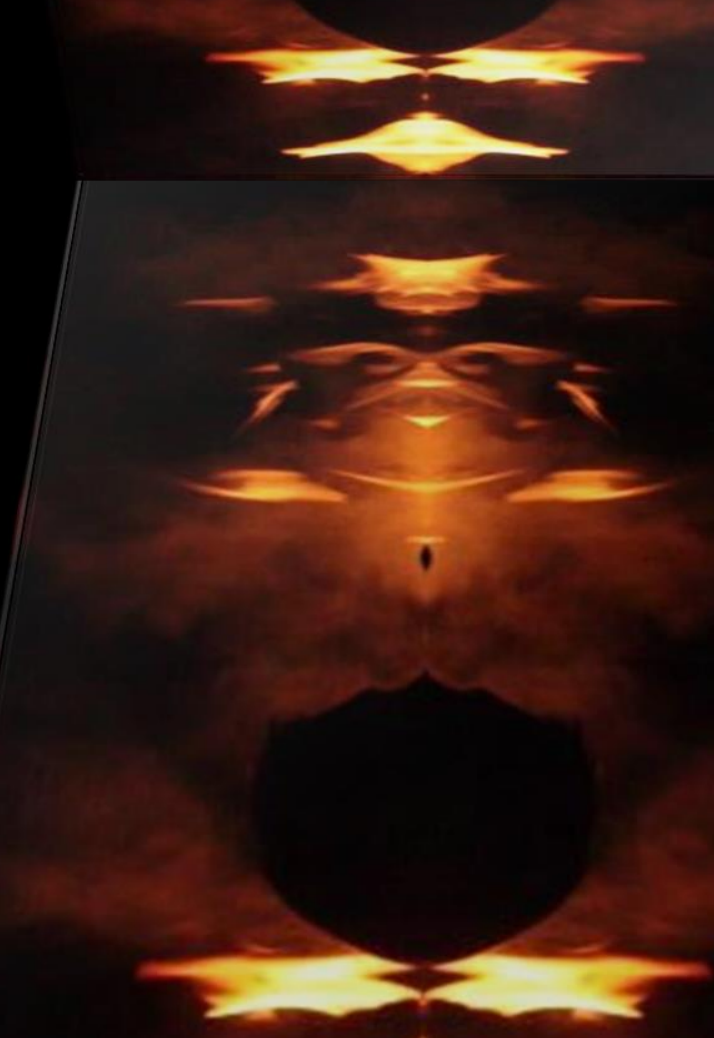

,

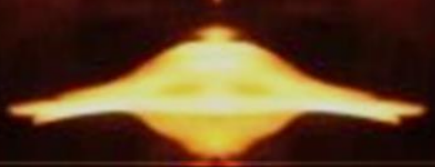




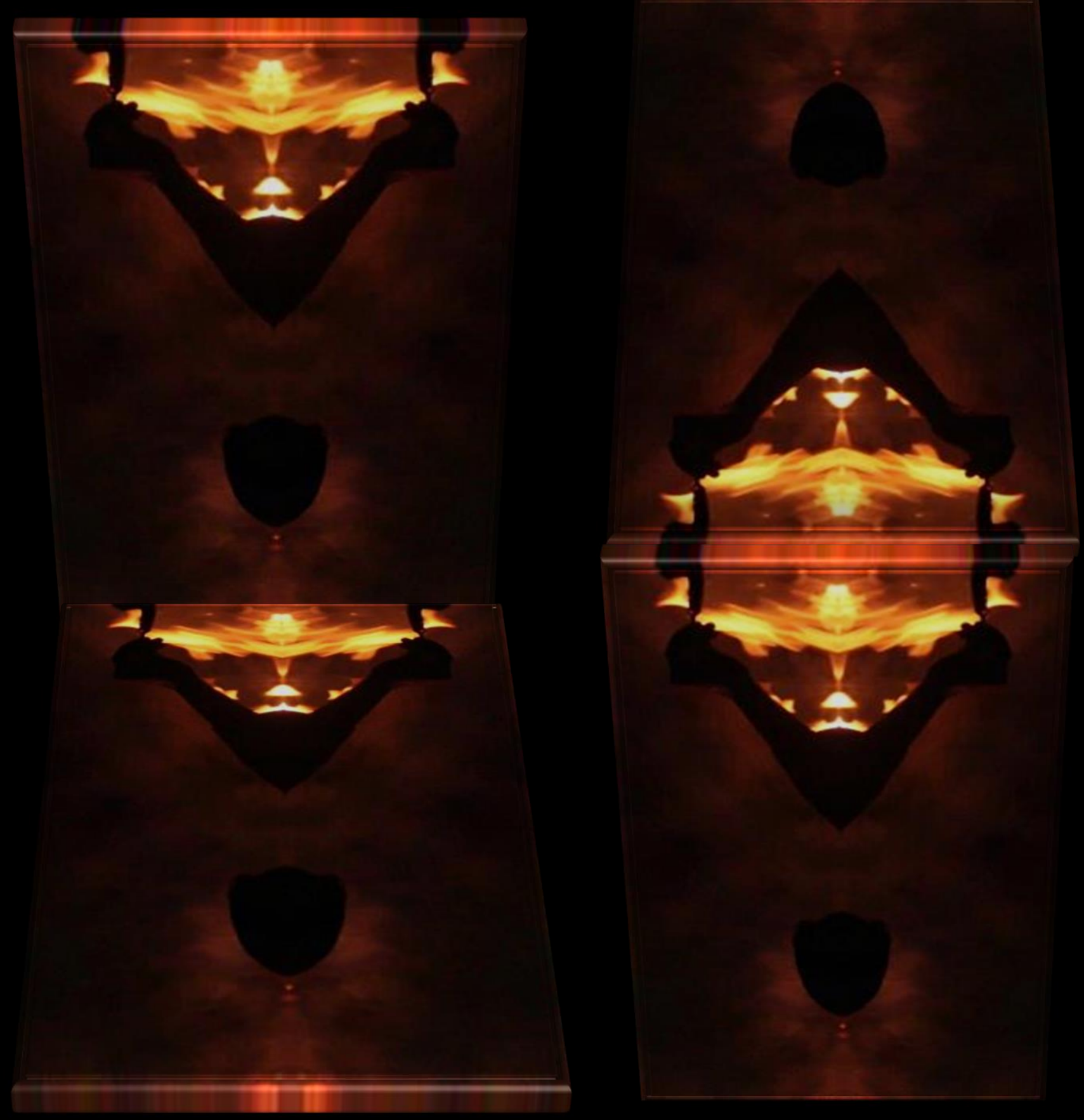




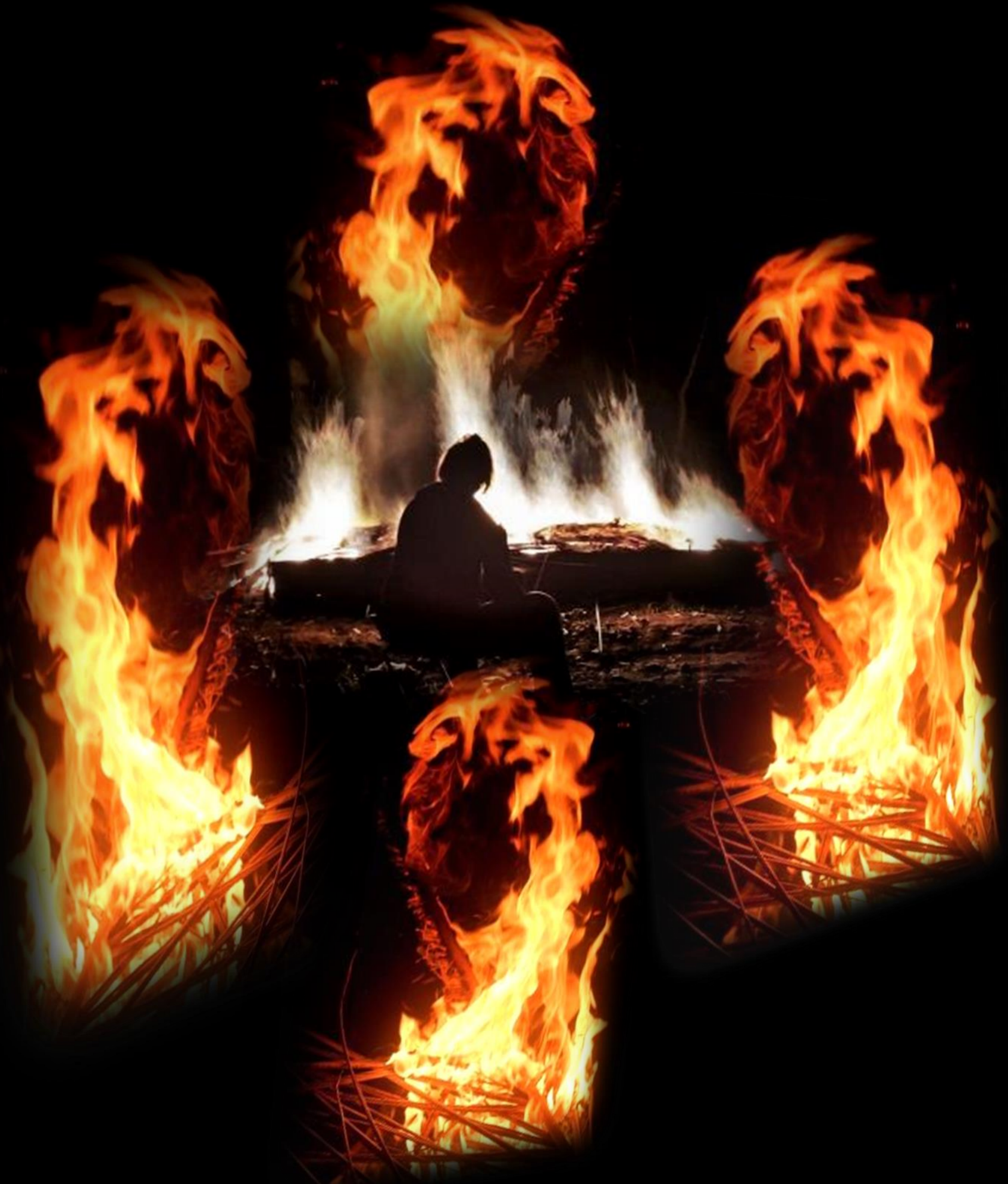




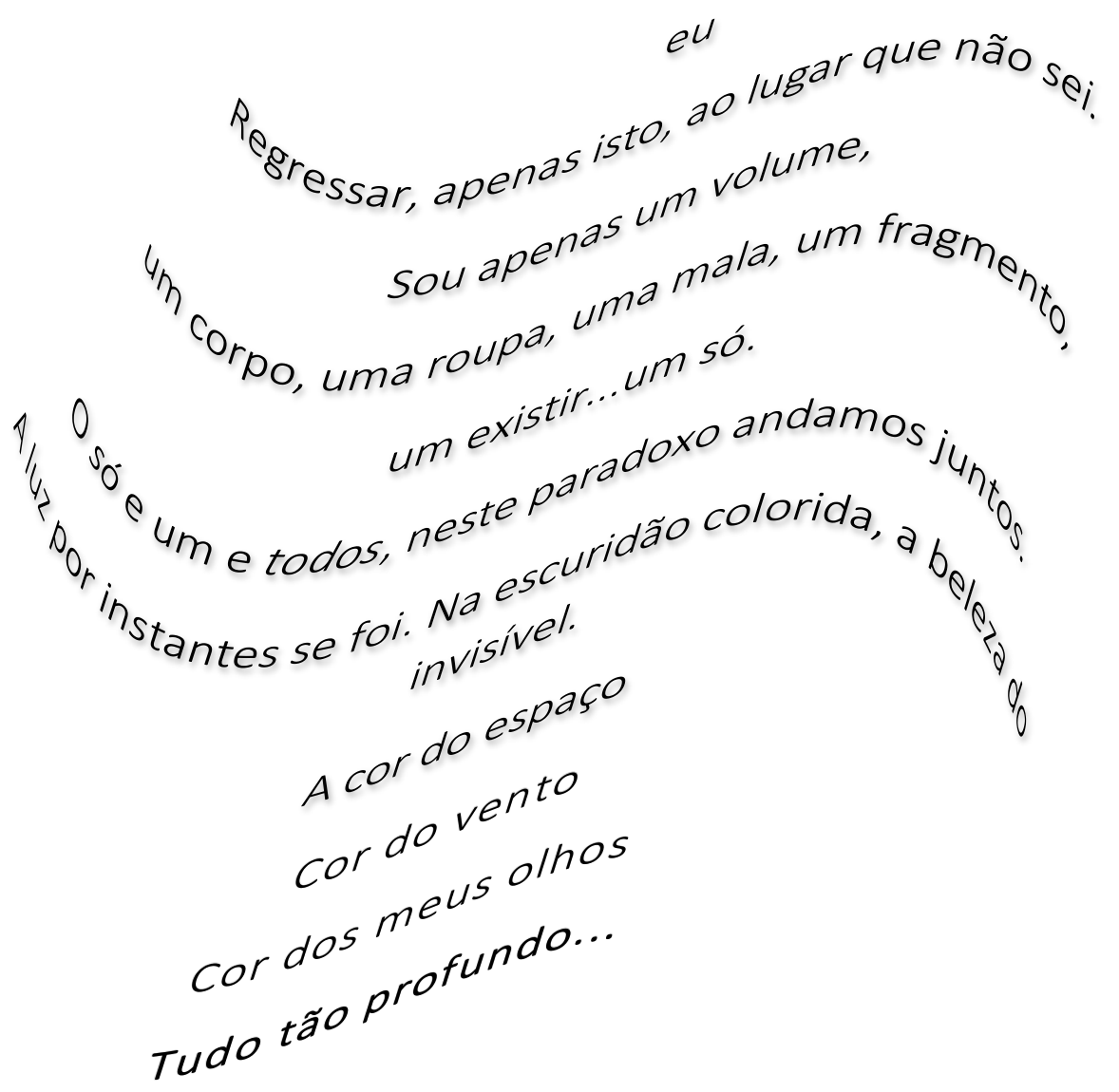

253 





Acordei cedo e cansada; esta tarefa consumia muita energia física. Eu me surpreendia com minha resistência, por vezes imaginava o trabalho árduo de mulheres do campo ou da roça. Este esforço nunca me desanimou, pois o entendia como um estado preparatório, e estar na mata é meditativo. Sempre gostei de meditações dinâmicas, acho sempre mais eficazes. Lá estava eu de novo com meu carrinho de mão verde, carregando lenha pela trilha. Existia um caseiro, Sr. Jorge, homem de meia idade, corpo forte, aparência rústica, mas com doçura nos olhos... Ele me visitava sempre que eu estava construindo as fogueiras, talvez desejando entender a razão daquilo. Me chamava de fazedora de fogo. Nesse dia, ele me trouxe alguns troncos robustos, acho que percebeu minha exaustão, e sua colaboração foi precisa. O tempo de montagem era menor, pois Ana Eliza chegou às 17 horas e tinha que buscá-la em uma cidade próxima. Ela vinha de São Paulo direto para a experiência.

Às 18 horas, estávamos de volta. Marco iria fotografar e Fernanda ficou como observadora. Foi tudo muito rápido; Ana tem formação musical em instrumentos de sopro e havia trazido alguns para a performance. Não tinha muita proximidade com ela, nos conhecíamos há pouco tempo, mas ela gostava de experimentações e fazia parte de alguns grupos de música experimental. Chegamos ao local às $18 \mathrm{~h} 30$ para acomodar os valiosos instrumentos - ela tinha preocupação com isso. Eu a senti tensa, desconfortável, trazendo preocupações técnicas, difíceis de resolver naquele momento, mas seguimos. Expliquei as ações básicas, o oráculo e as tochas. Como estávamos em quatro, cada um acendeu um 
ponto. Antes de iniciar, já percebi uma falha no processo, que dizia respeito à metodologia: a performer havia colocado esta condição para participar do trabalho, ou seja, de chegar direto, sem preparação e eu aceitei. Ela não vivenciou o rito preliminar por seus compromissos, e não tinha conhecimento desta necessidade, portanto a responsabilidade era minha. Também não houve tempo prévio para a performer se estabelecer no espaço, arrumar seus objetos e buscar suas alternativas. O campo de presença apresentava diferentes energias, e isto limitou o acontecimento. Foi um aprendizado que trouxe certezas e potência para a metodologia. Por esta razão, foi de grande valia.

Marco e Fernanda foram importantes para estabelecermos uma relação de coletivo e colaboração, fundamentais nas práticas. Confesso que pedi proteção aos guardiões que até então nos acompanhavam nesses labirintos de luz. Acreditei que a força do elemento poderia nos dar um direcionamento. E iniciamos os trabalhos. 


\section{HIEROFANIA 5 - A Natureza responde}

Local: Sítio Moinho Velho

Município: Cunha/SP

Carta do trabalho: Carta 41 - A morte do Xamã

Acendendo fogo: $19 \mathrm{~h} 05 \mathrm{~m}$

Final do trabalho: $21 \mathrm{~h} 13 \mathrm{~m}$

Câmera 1. Cláudia de Bem (pesquisadora) Carta 27 - O Berço

Lente: 70/20mm aberturas 2.8 macros

Performer: Ana Eliza Colomar. Carta 12 - A Flecha

Colaboradores: Marco Perez. Carta 29 - Contador de Histórias

e Fernanda Valadares. Carta 4 - A Cerimônia do Peiote 


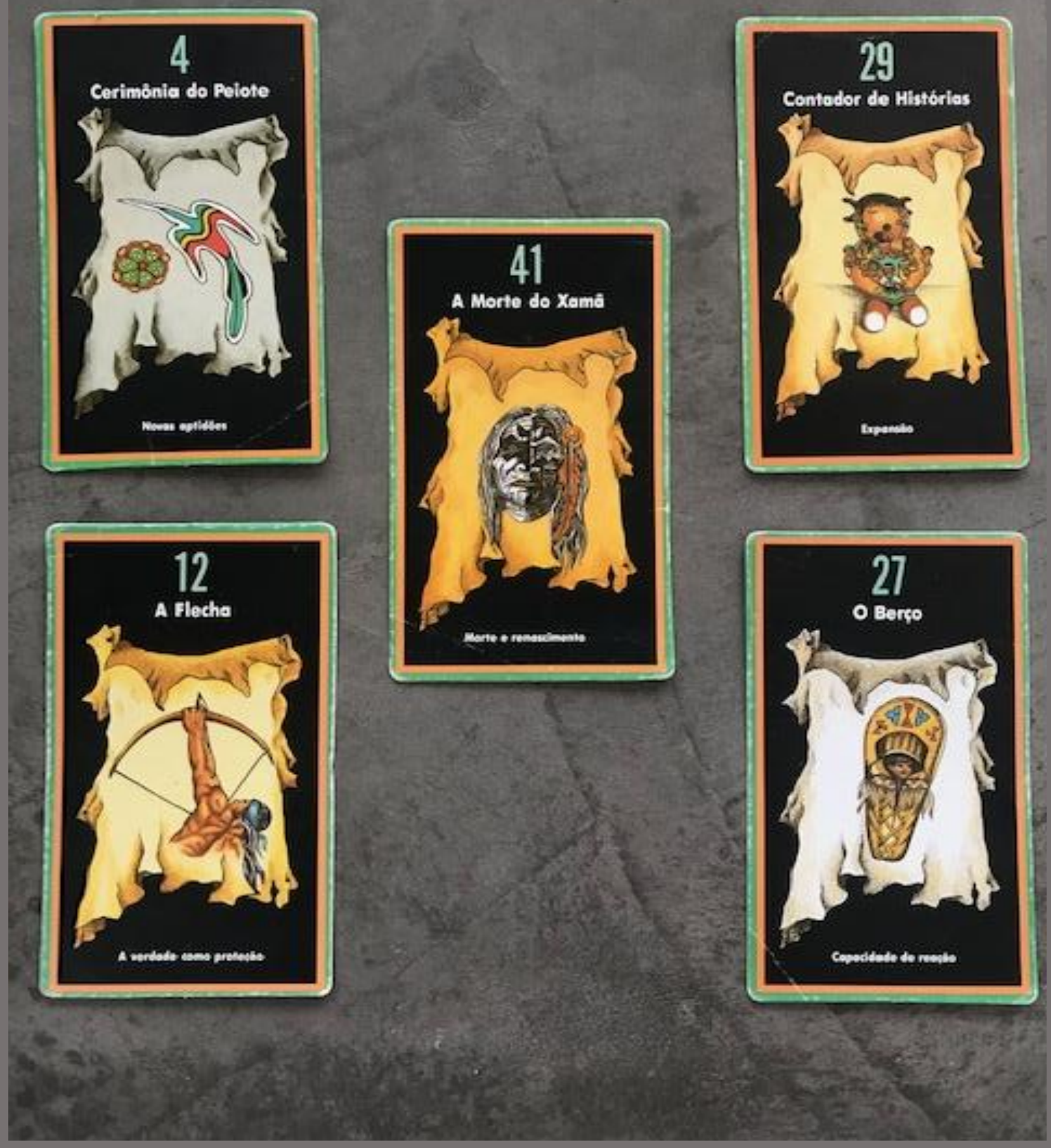


ORÁCULO

A MORTE DO XAMÃ

AVÔ

PEÇO A MORTE

PARA AS PARTES DE MIM

QUE NÃO OUVEM

NEM FALAM A VERDADE

QUE SÃO CEGAS DEMAIS PARA VER

AVÓ

DÁ-ME À LUZ DE NOVO

COM O AMOR COMO MEU GUIA

A VERDADE E A BELEZA COMO MEU CAMINHO

SEM NADA A OCULTAR 


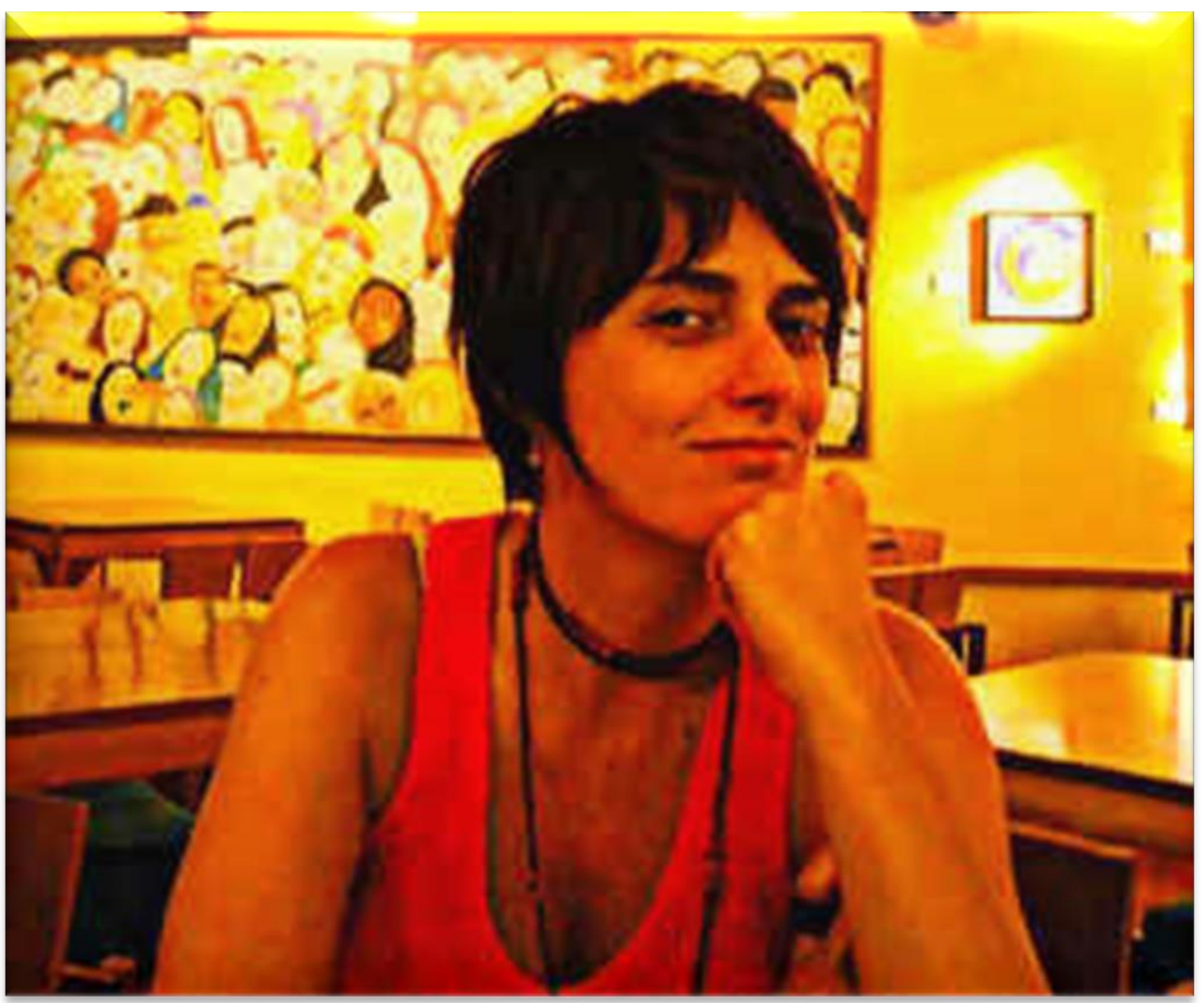

Crédito da foto: cedido gentilmente pela performer 
Não vou fazer um relato minucioso das minhas impressões sobre a performance. Busquei apenas captar as imagens, deixar meu olhar performar e não me ater a narrativas ou leituras corporais do performer; não me cabia esse tipo de interpretação. A performance é o que é, o momento, a presença; o estar, o ser, o fazer; não me compete este controle. O que importava era a vivência de cada um. O barco Viking acendeu novamente e Ana viajou nele com seus sons e sua atenção na chama. Houve um momento sublime e percebido por todos, em que um pássaro respondia ao estímulo de uma flauta indiana que era feita de madeira. Ao perceber, ela começou a estabelecer um diálogo com o pássaro. Lamentei por não ter um equipamento de som naquele dia para a captação dessa conexão. A performance durou cerca de uma hora e os sons junto com o fogo estabeleceram harmonia, paz. Daquele dia, não lembro de a chama ter sido tão intensa. Ao olhar as imagens de vídeo, observei uma qualidade e tom suave da luz, amarela e enevoada.

Ana Eliza se retirou, fez suas anotações e encerramos, indo para casa saborear as pizzas que eu havia pedido para o Marco fazer de novo. Conversamos bastante sobre a experiência, e Ana relatou seu desconforto inicial com o calor, a desafinação dos instrumentos e a superação no decorrer da performance.

Seu depoimento do caderno é bem sensível e revela suas conexões. Fernanda nos presenteou também com desenhos estilizados da fogueira e Marcos com suas fotos. Creio que foi uma noite de presentes, de superações e quem responde é a natureza. 







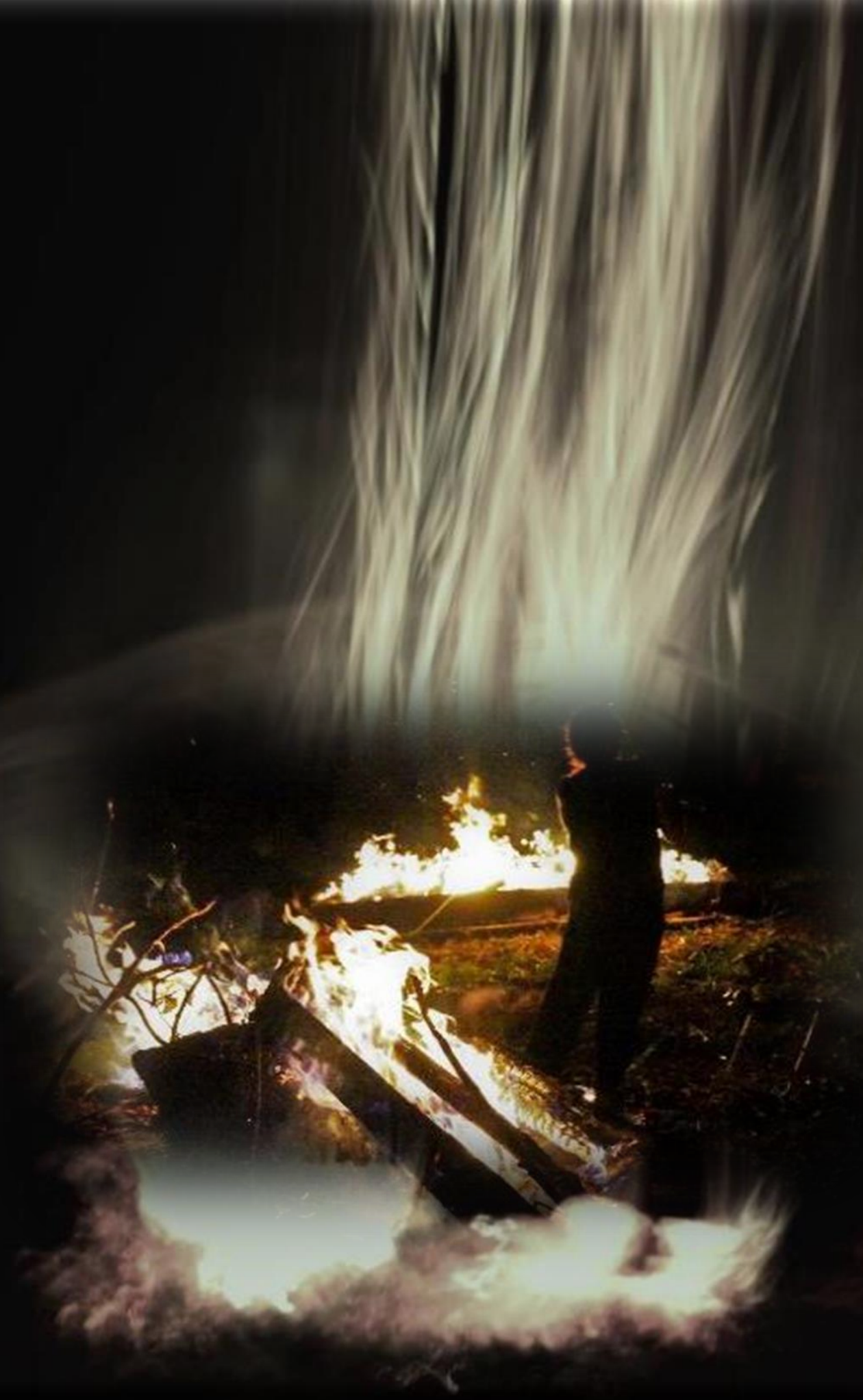




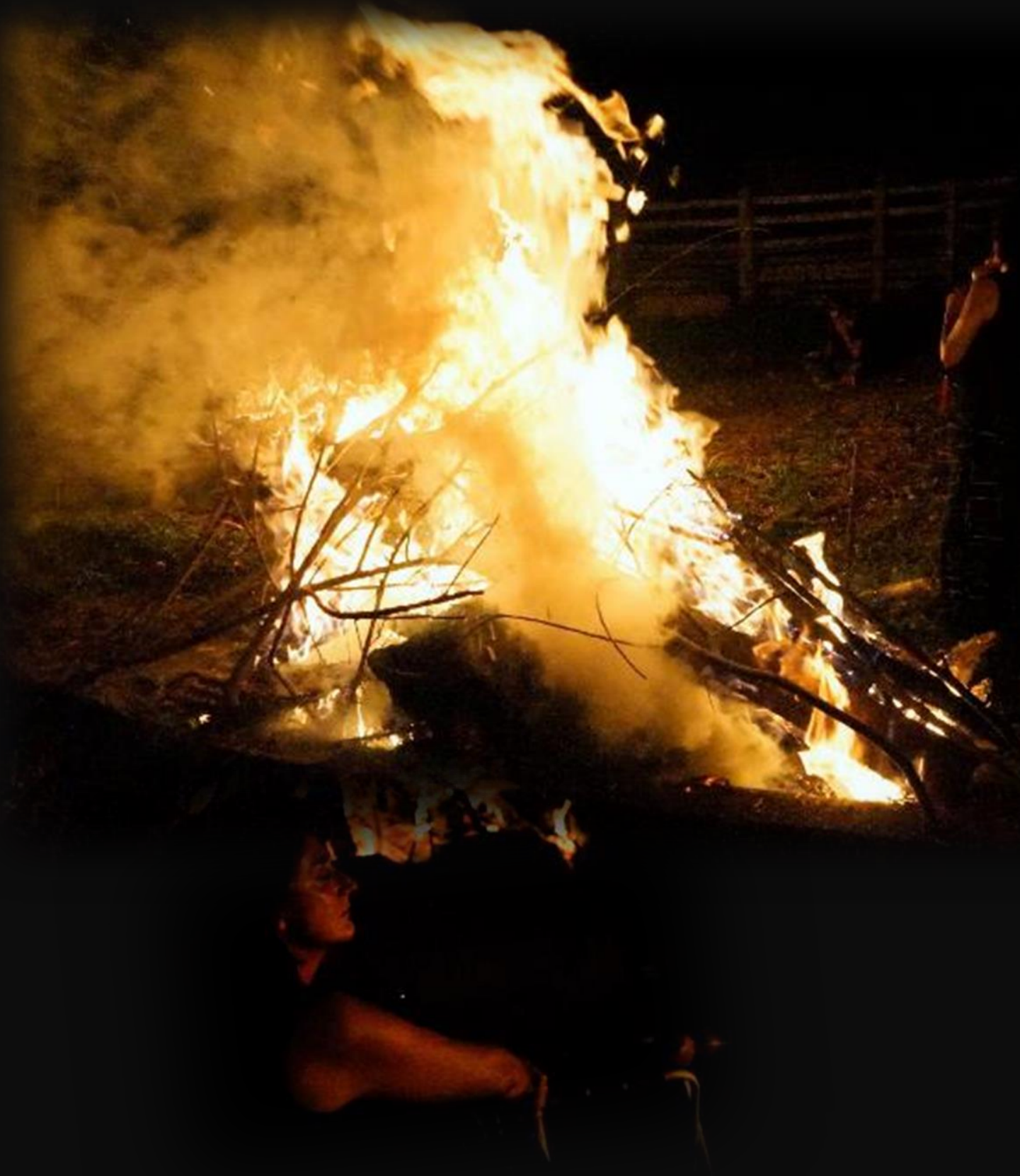


RELATOS DA PERFORMER

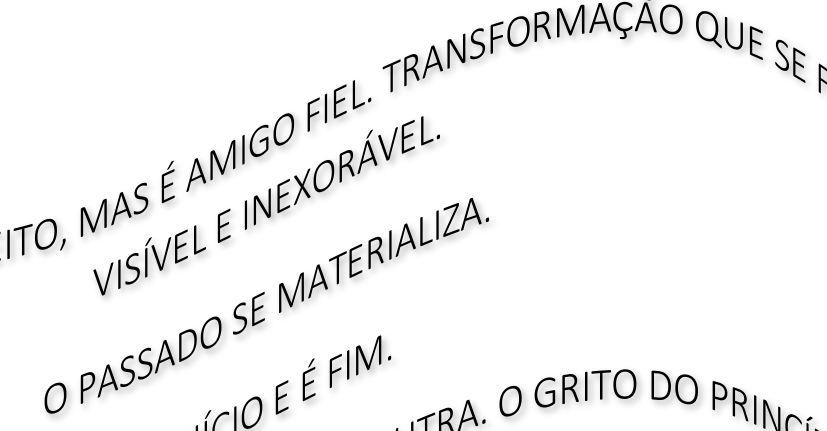

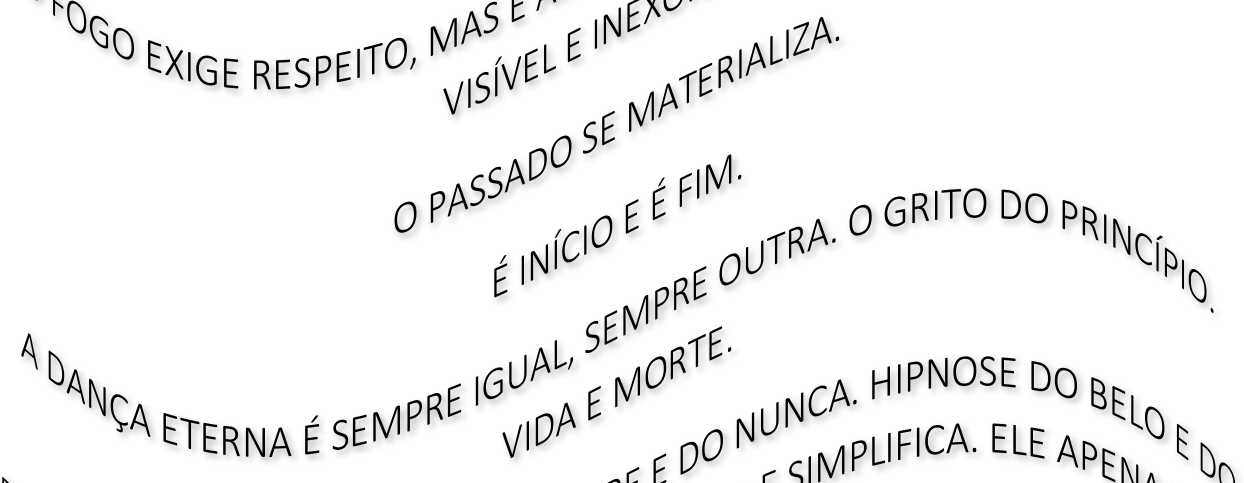

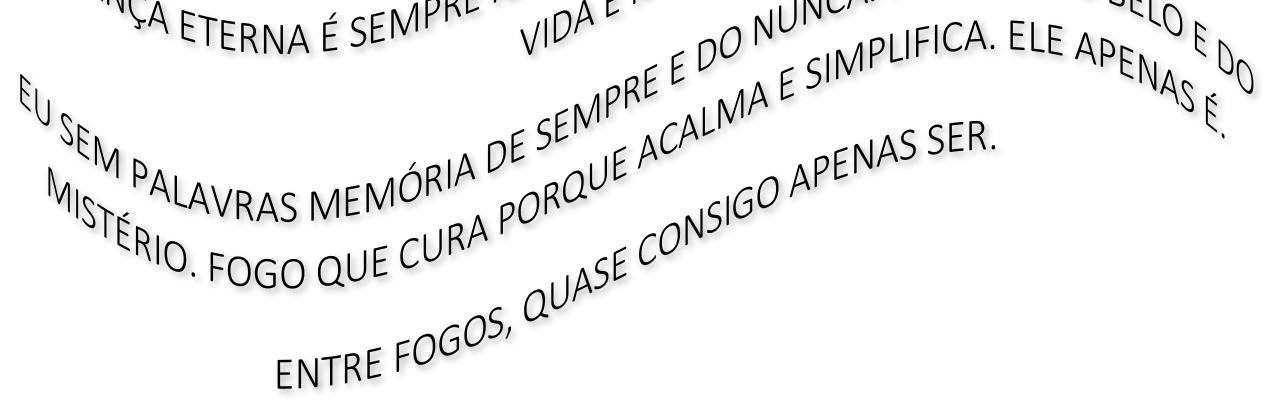

265 
Figura 8-Desenhos de Fernanda Valadares

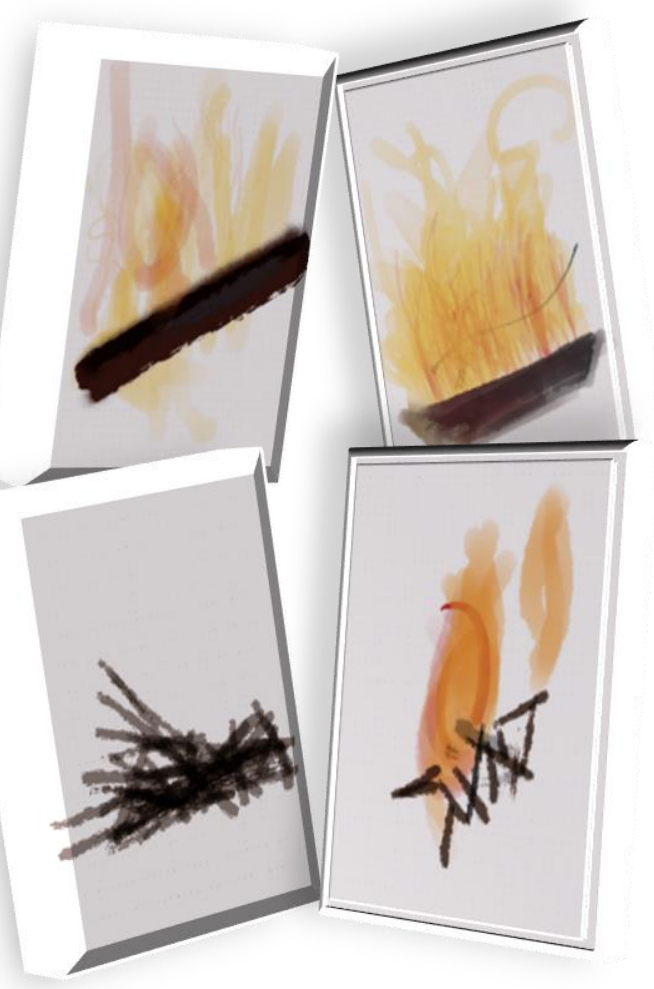


No outro dia, antes de partir, fomos ver as Pecans e visitei minha árvore que lutava por sobrevivência. Foi nessa ocasião, como relatei anteriormente, que me enxerguei ali como ela, frágil e triste.

Neste ano, 2020, eu me comuniquei com eles e perguntei se a permanência deles era definitiva. Fernanda me escreveu:

Naquela época, fomos engolidos por aquele lugar. A gente resolveu viver aqui casualmente. Hoje admito uma potência incrível para a prática artística em estar fora da cidade, a cidade é o ninho da distração. Perto das coisas que são mais simples, e não só da natureza, a gente consegue ter mais foco e entender o ciclo das coisas, das estações, de planta que cresce, dos bichos que nascem, crescem e morrem. Enfim, o ciclo da vida. Quanto às árvores, o 'muda conversa', te digo minha amiga, continuo a ver o tempo das coisas e das árvores, são estes trabalhos que vamos aprendendo com as rasteiras que eles nos aplicam. Te conto em outro momento os detalhes. Tua árvore está firme e forte. $E$ sempre lembramos de você quando fazemos fogo. A quarentena tem sido o que foi nos últimos anos para nós, o difícil é ver o que está lá fora.

Fernanda Valadares

Fiquei feliz com as notícias, principalmente por crer nestas escolhas de uma práxis artística integrada e abastecida na natureza. São processos que me interessam . 
UAP - USINA DA ALEGRIA PLANETÁRIA

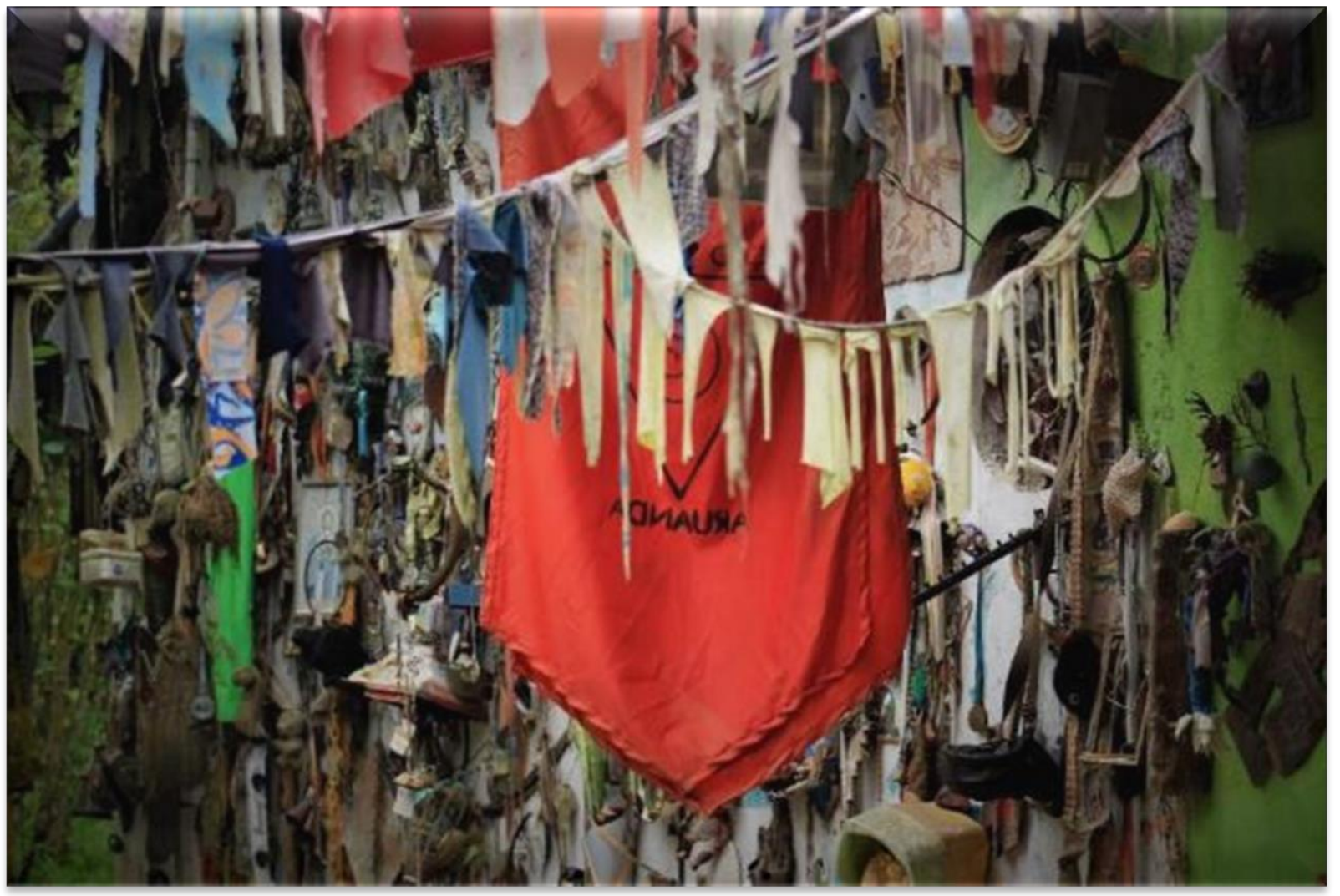


A Usina da Alegria Planetária (UAP) é uma plataforma de criação e pesquisa que, desde 2010, propõe a troca livre entre artistas com base na interdisciplinaridade, na experimentação de linguagens e na reinserção de materiais, indivíduos e o entorno. Está localizada a aproximadamente 40 quilômetros da capital de São Paulo, na zona rural de Cotia, bairro Caputera, que faz divisa com Embu das Artes, numa região caracterizada pela escassez de equipamentos e atividades culturais.

A sede contribui com a sensibilização para o modo orgânico de viver e se relacionar com as pessoas, com o ambiente natural e seus ciclos. A estrutura física é composta pelo Ateliê Usina, um galpão-estúdio de $260 \mathrm{~m}^{2}$ construído em formato de oficina integrada que permite o contato entre suas áreas criativas - ateliês de marcenaria, confeç̧ão e costura equipados com maquinário e ferramentas, espaço dinâmico para processos criativos, experimentos e apresentações - além de biblioteca, acervo de materiais para prática, camarim e cozinha. A construção, com acessibilidade universal garantida, privilegia a minimização dos impactos ambientais através da reinserção de materiais, captação de água da chuva, aproveitamento de luz natural e área externa reflorestada com espécies nativas. A estrutura também conta com dormitório coletivo para receber artistas e participantes das atividades programadas.

A UAP funciona como um agente articulador para o desenvolvimento de práticas artísticas com uma metodologia transdisciplinar que é aplicada em diferentes projetos, 
estimulando a expressão individual e seus riscos a favor de uma estética de participação e fazer coletivo. "[...] deslocamento de um olhar 'sobre' a natureza para o próprio ato de perceber-se como parte do todo, estimula a reflexão e revisão dos valores e a potencialização dos sentidos" $"$ "47.

RESIDÊNCIA E RESISTÊNCIA

Em outubro de 2018, optei por fazer uma residência na UAP, buscando compartilhar experiências artísticas com aquele coletivo, realizar o laboratório prático e vivenciar aquele espaço de integração arte-natureza que dialogava com a pesquisa. Pretendia me proporcionar um momento de imersão e conexão da pesquisa a outras práticas artísticas transdisciplinares. Meu primeiro contato com a UAP foi através do cenógrafo Renato Bolelli Rebouças, que conheci no programa de doutoramento na USP/ECA. Ele era um dos integrantes e residia lá.

Eles oferecem um espaço para os artistas residentes que desejam isolamento, mas optei por me hospedar na casa de um dos artistas, Beto Guilger, Bukuritós Aruanda, que ali reside, pensando numa convivência mais próxima com o cotidiano do coletivo.

Chovia muito na minha chegada e me ocupei de organizar o material e escutar aquele espaço tão excêntrico, preenchido com falas ocultas, objetos e imagens que

\footnotetext{
${ }^{47}$ UAP. Disponível em <https://www.uap-residence.com> Acesso em JUL2020
} 
guardavam segredos. Naquela residência viviam dois artistas: Bukuritós Aruanda (artista visual) e Renato Bolelli, porém nos vinte dias em que lá residi, Bolelli estava em residência artística em Nova lorque. Éramos Bukuritós e eu.

Na própria residência ficava o Atelier de Bukuritós. A sensação logo ao entrar é de que a casa toda era o Atelier, inclusive no espaço externo. As plantas, os objetos, as instalações internas e externas, as obras, tudo respirava arte e natureza, existia uma integração entre o comportamento e o ambiente. Esta sensação estava materializada nas paredes, no mobiliário, no piso, nas janelas, no jardim. Ministro aulas de percepção aplicada a projetos arquitetônicos numa linha de pensamento de humanizar os espaços, atribuir uma interatividade e sensorialidade para àqueles que os habitam de acordo com suas necessidades. A casa de Bukuritós era um exemplo concreto de espaço sensorial, um ambiente que visivelmente carregava memórias e sentimentos. No primeiro dia de permanência já via vestígios da sua alma. Outra característica das casas dos habitantes da Nação Aruanda é que elas traziam características do Orixá de cabeça do morador. Bukuritós é filho de Oxumarê. Na mitologia dos Orixás, conta-se que ele não tinha simpatia pela chuva, e quando ela vinha, ele fazia com que desaparecesse, dando lugar ao arco-íris; por isso é conhecido como Orixá das cores. A casa de Bukuritós era a mais colorida de todas, assim como sua arte. A obra é bem diversificada, com técnicas de pintura, colagem com diferentes materiais (tecido, tinta, tela, folhas, sementes), 
instalações e elementos de performance, como vestes e acessórios. Aos poucos fui percebendo uma mística na essência de sua estética.

A área rural em que está localizada a UAP não é plana e tem alguns labirintos para acesso às unidades. Como chovia, não conseguimos sair para explorar o espaço, tampouco coletar material. No dia seguinte, a chuva permanecia torrencial, sem condições de prosseguir na pré-produção da hierofania, e assim permaneceu por quinze dias. Decidi me desligar um pouco do objetivo da pesquisa e conviver naquele espaço que apresentava uma dinâmica diferente do meu cotidiano. Existiam uma estrutura e uma prática organizacional orgânica entre o espaço e as pessoas. Este equilíbrio se dava por um ingrediente humano: a consciência. Aos poucos eu ia percebendo a rede e me adaptando a novos hábitos com relação a reaproveitamento da água, dos materiais recicláveis, da relação com o lixo e as práticas de separação e despacho, ações de cuja responsabilidade a estrutura mecanicista das nossas cidades nos faz esquecer.

Bukuritós, além de um excelente anfitrião, exerceu papel de incentivador para que eu experimentasse livremente novas linguagens. No segundo dia, me disponibilizou o espaço do atelier e suas ferramentas. Penso que linguagem é um código segundo o qual selecionamos, interpretamos e organizamos os estímulos, traduzindo-os em uma imagem significativa. Ao sentar-se na sua mesa, de repente me vi ali, no mundo colorido de Bukuritós, olhando suas representações por todos os lados. Eu havia trazido um caderno laranja de capa dura destinado a ser um diário, a princípio de palavras, mas a 
primeira página se preencheu com uma abstração daquele espaço impregnado de formas visíveis e invisíveis onde identifiquei a aura, o espaçamento entre meu olhar e o ateliê de Bukuritós, e foi um excelente exercício.

Foi o início para que o caderno laranja se transformasse em performance, com as folhas preenchidas das ações e instalações durante o período em que permaneci ali. Aos poucos, as palavras foram desaparecendo, trocadas por desenhos, colagens e outras imagens. Decidimos que o caderno laranja ficaria aberto para nós dois, e o preencheríamos quando desejássemos. Estabelecemos um diálogo através dele, um objeto sensível de trocas. Quando retornei para São Paulo, encontrei várias mensagens imagéticas de Bukuritós no nosso caderno laranja. 


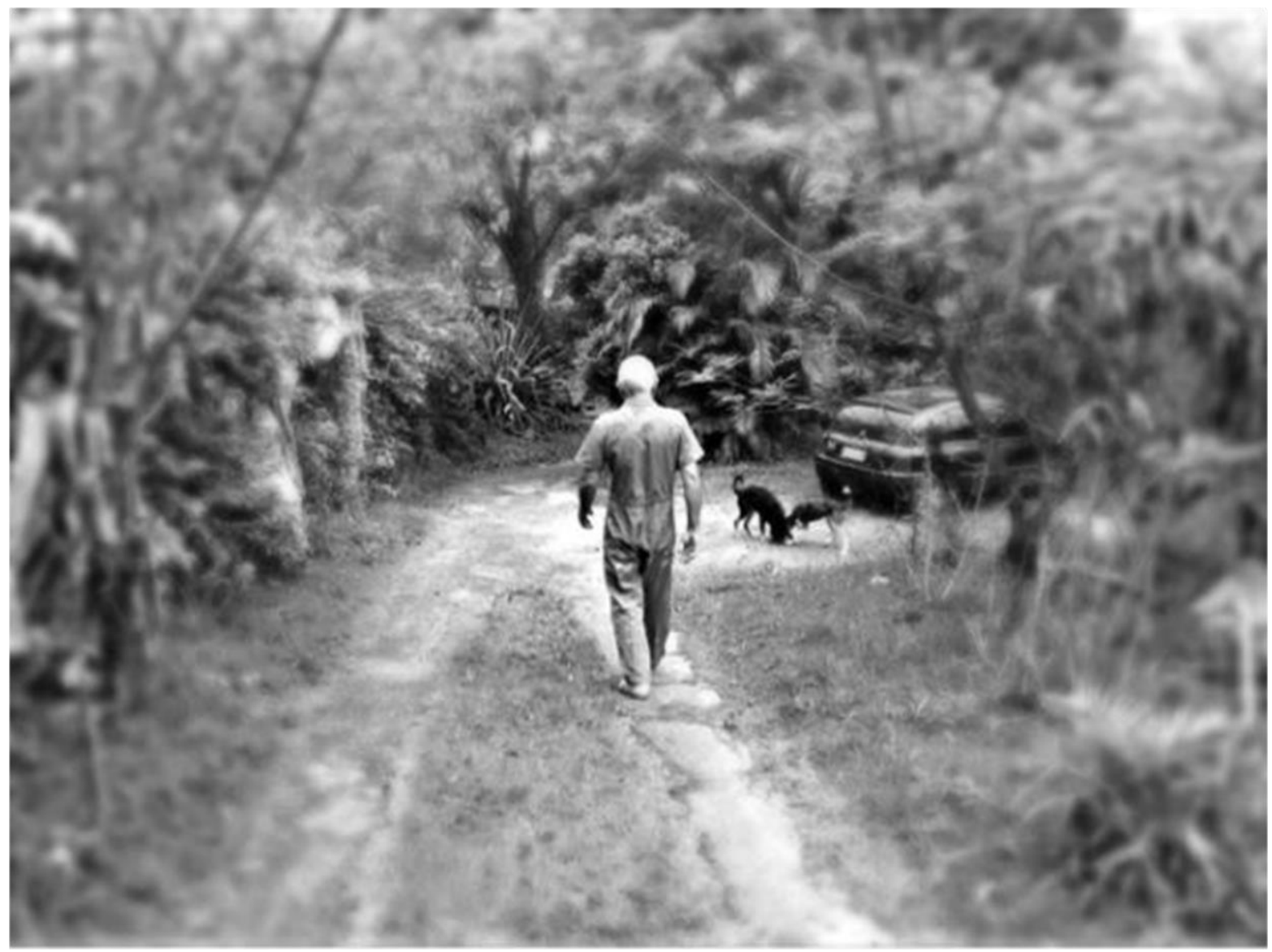

274 
OUTRAS JANELAS

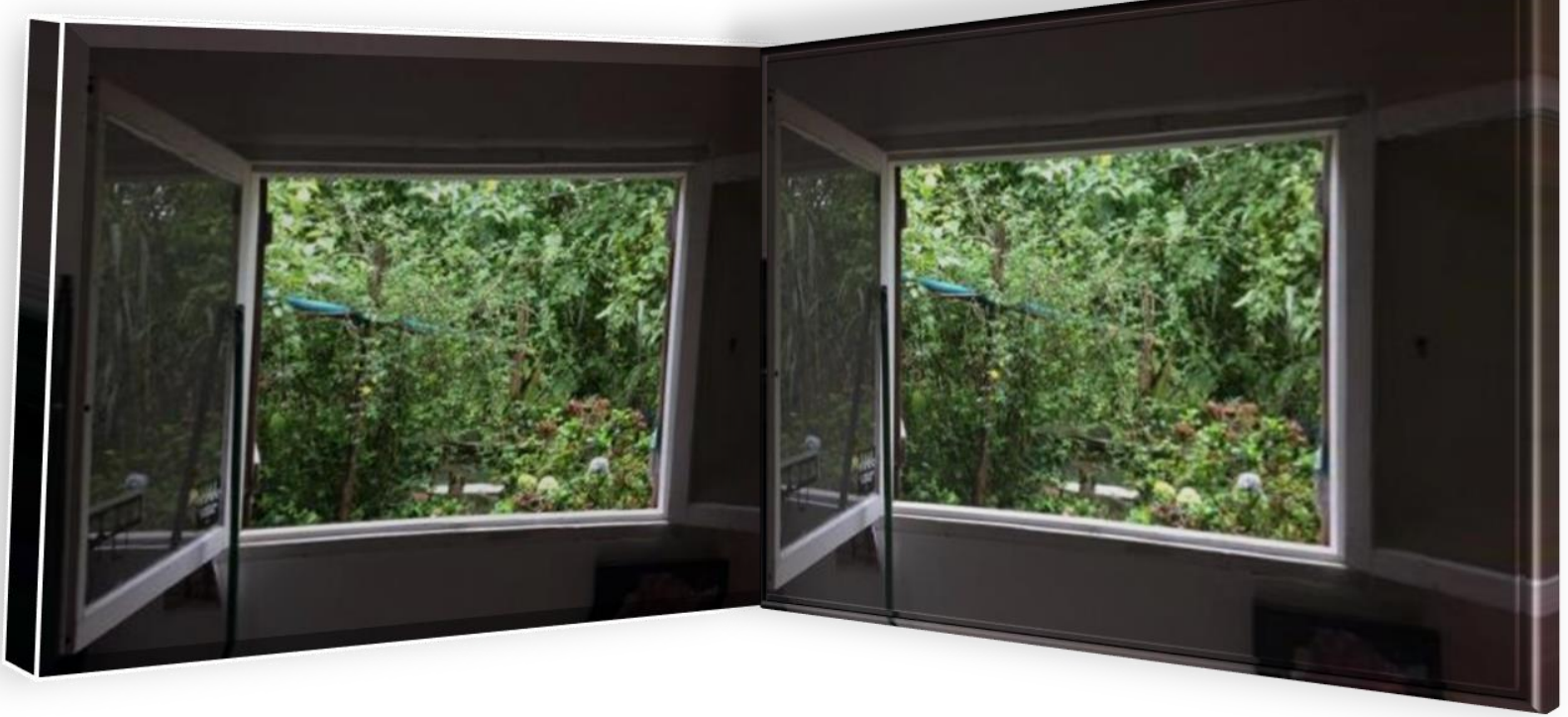


ATELIER

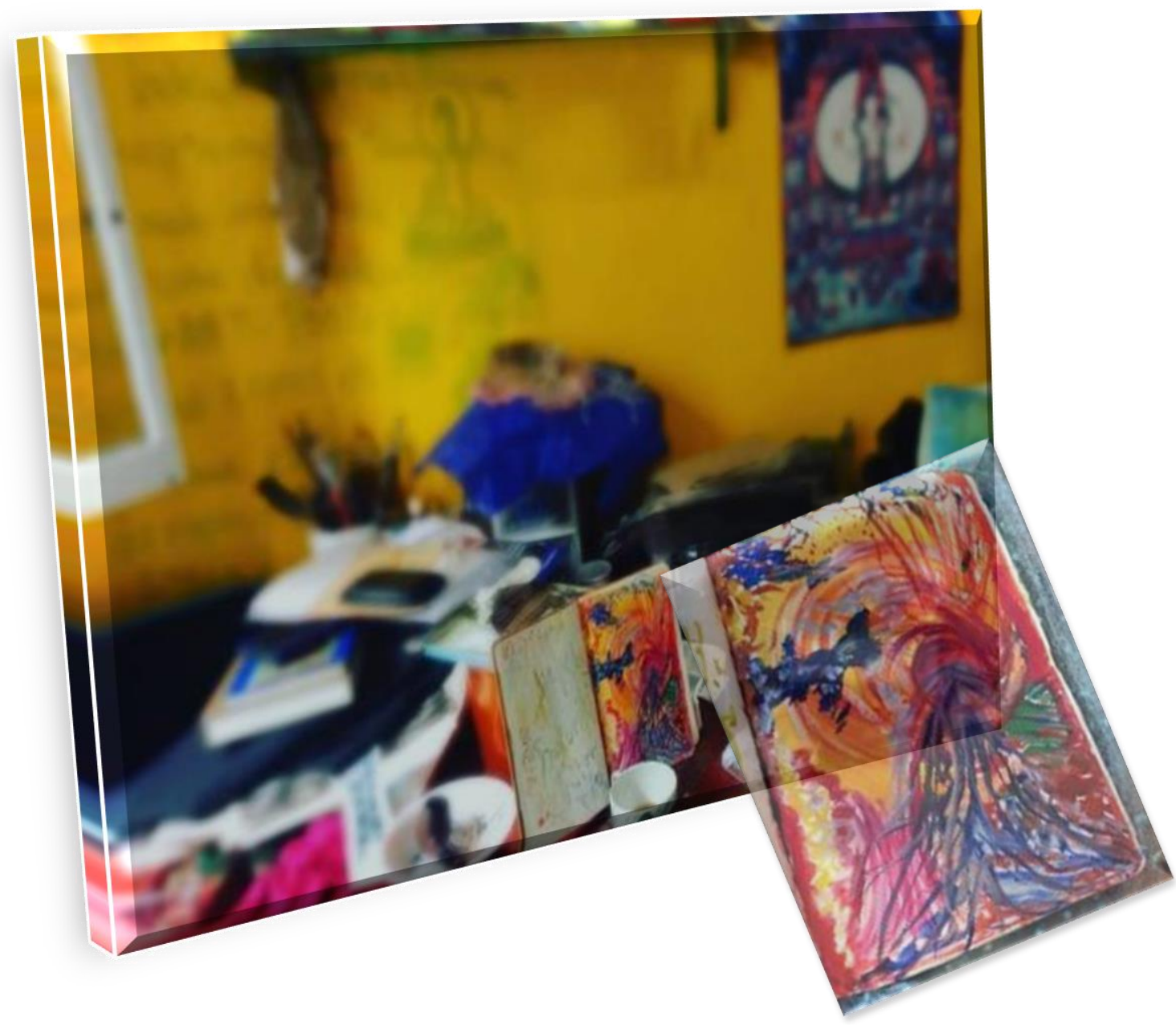

276 


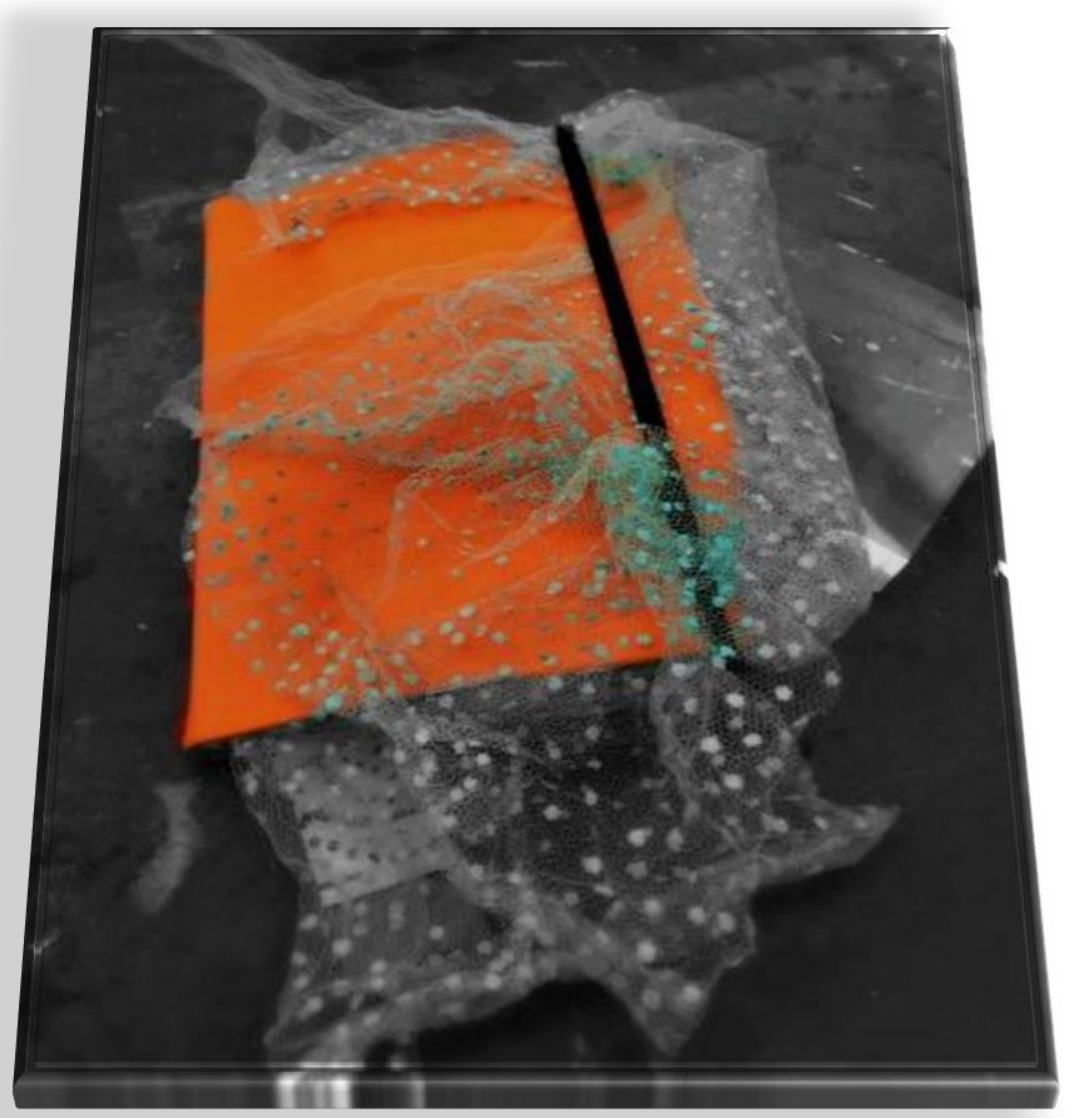

277 
Caderno Laranja, segunda feira ... 08 de outubro de 2018 ... produção

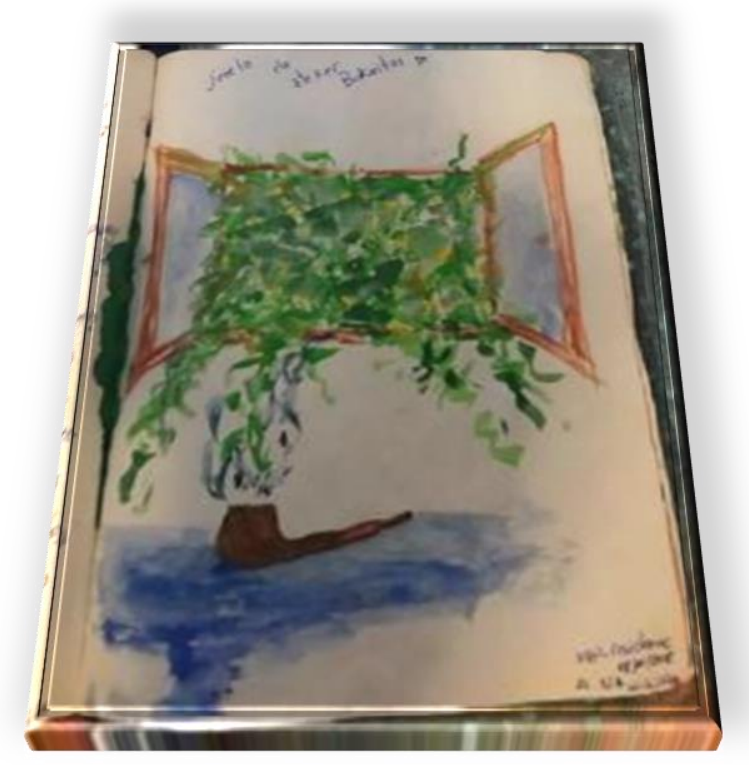

Dia de um Brasil triste, nublado, ruindo.

Aqui o tempo acompanha, a chuva tenta limpar esta fuligem dos tempos.

Compartilho um espaço que respira emoções, arte, desordem e uma infinita sabedoria. A mesa do Atelier de Bukuritós amontoada de ferramentas que desconheço, mas vejo como prolongamentos de uma atitude daquele espaço para meu espaço.

Trago meus companheiros > um pouco de fumo cherry, o cachimbo, aquarelas, a porcelana com café, a caneta, a letra desparelha, a caixinha de palitos de fogo e as portas do caderno laranja. A janela é uma fenda com todos os verdes possiveis e alguns pontos amarelos disputando, juntos, uma trilha pingando. Respiro...e faço fumaça. 
Caderno laranja, terça feira, 09 de outubro de 2018.

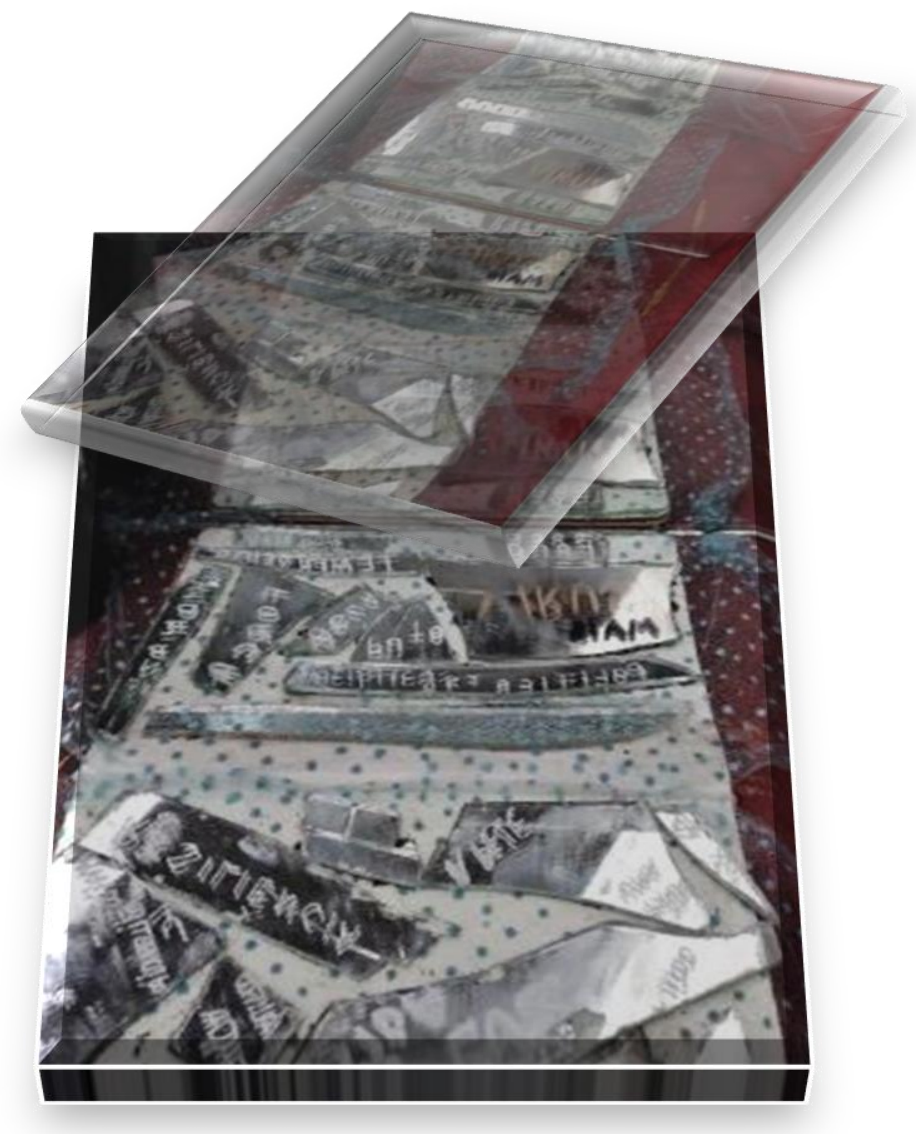

"Inversos das palavras refletidas no suave poá do Tule enrugado".

Chega o sol com as cores e seus reflexos nos trazendo palavras. Hoje está sendo assim, criar e brincar com palavras invertidas espalhadas nos cacos espelhados.

Surge nosso lago de letras, fonemas e

vozes.

De novo os reflexos.

Nasce nosso lago entre nossas e malditas palavras tortas... 


\section{(⿻) $7 \times$}

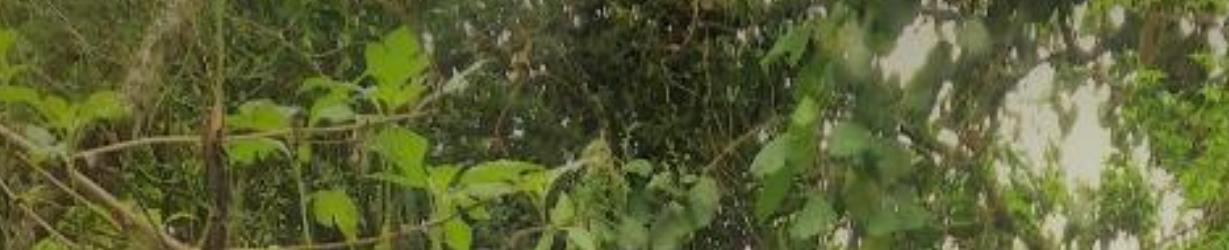

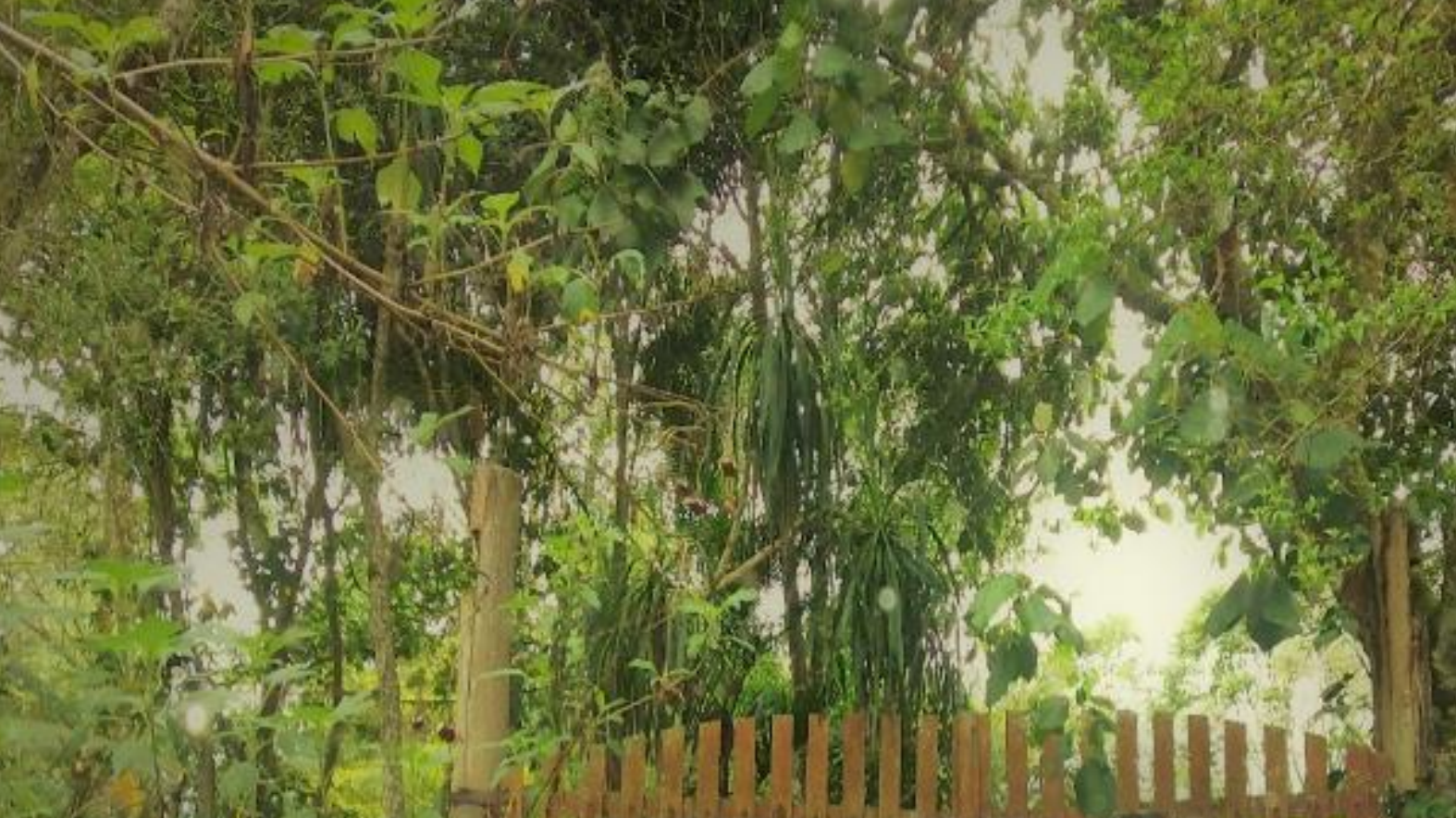

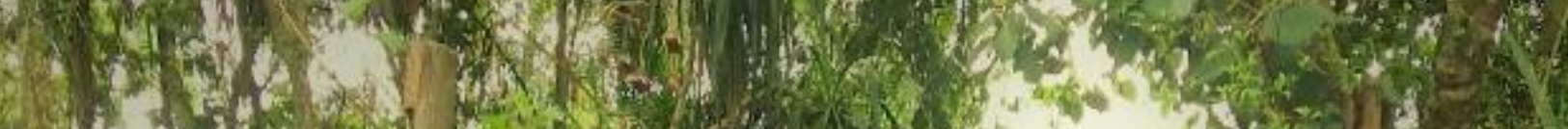
car 10.21 for.

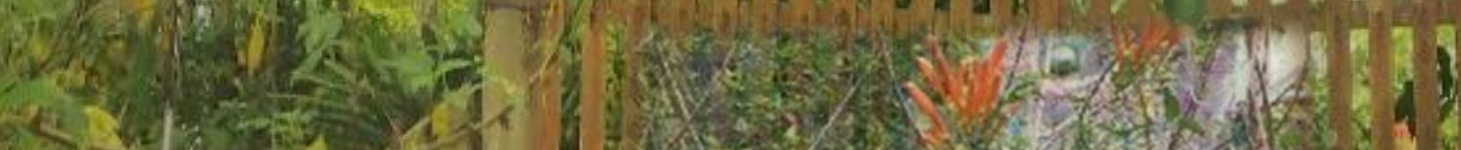
Nito 19 (1)

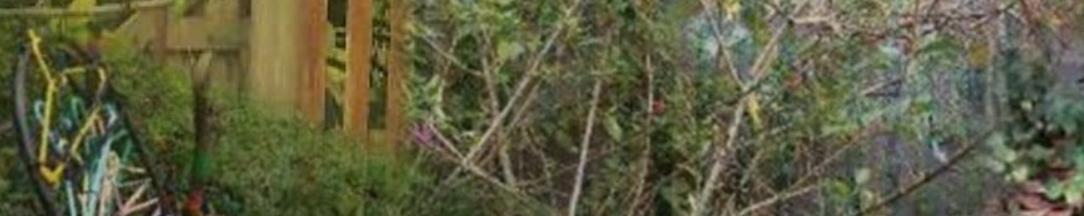

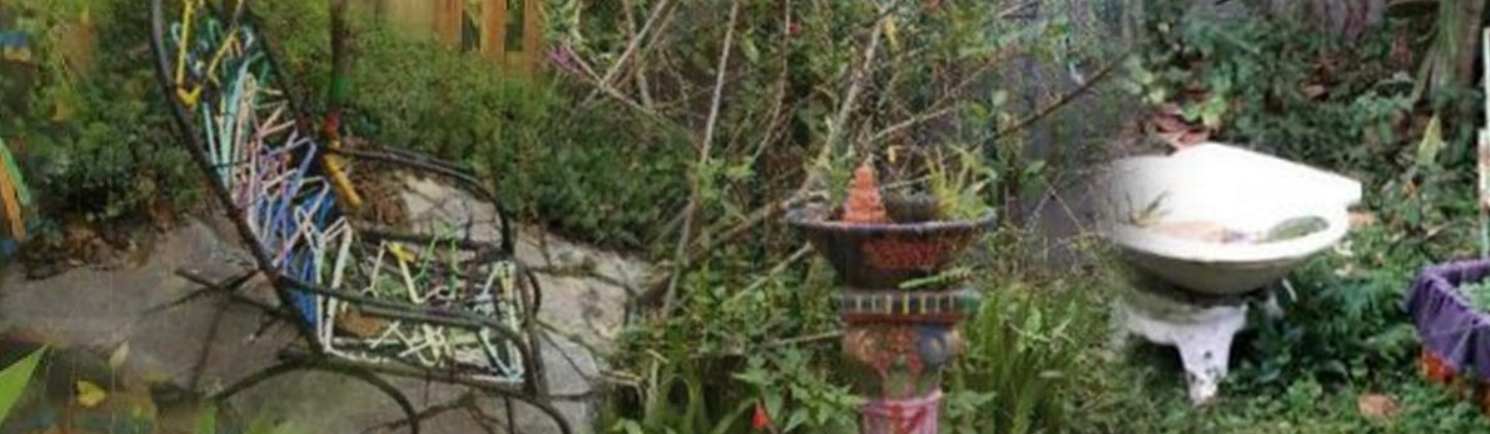

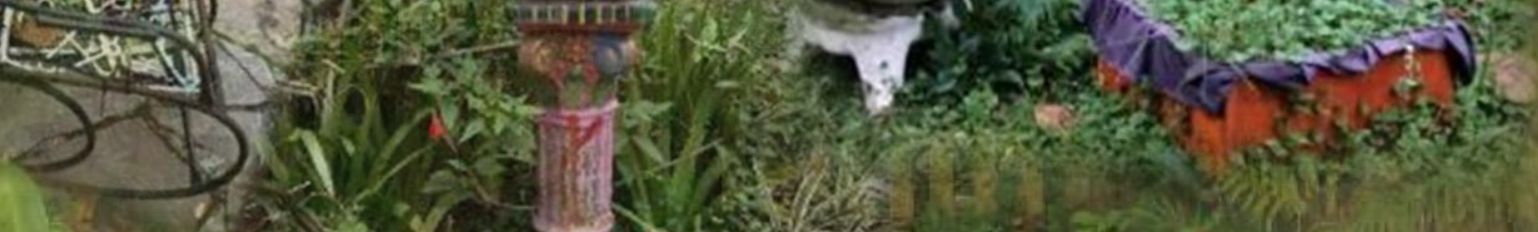

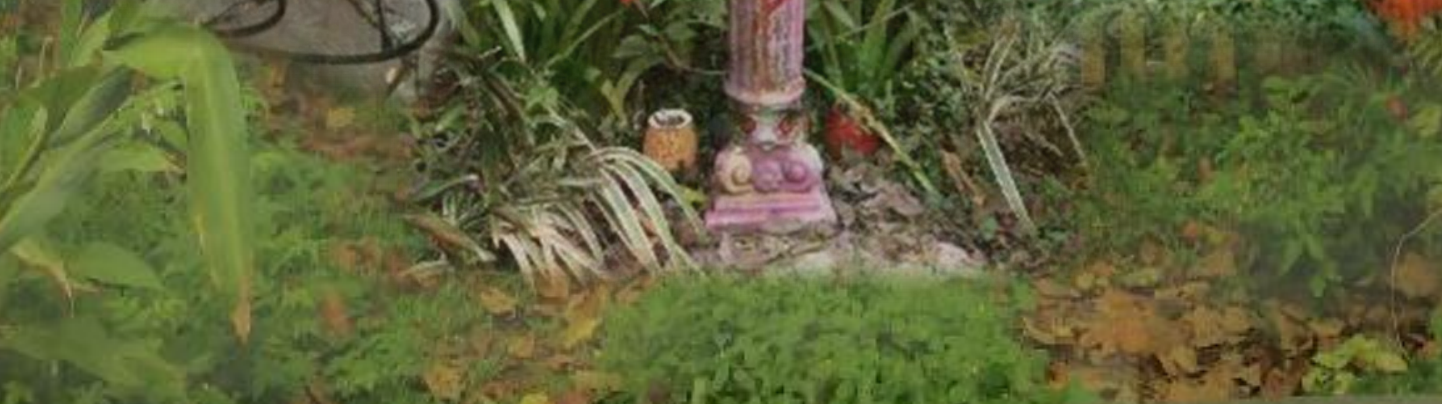


Nos dias que se seguiram, a chuva acalmou e fui conhecer o atelier da Usina e o mestre Kabila Aruanda, performer e figurinista. Todo seu aparato de confecção fica nesse atelier, onde ele produz diariamente. O espaço é um grande galpão com pé direito de aproximadamente 15 metros de altura. A imagem que se tem ao entrar é de uma potência artística incrível. São muitas instalações que vão performando o espaço. Creio que nos dias em que estive ali não consegui absorver metade das informações. O coletivo prescinde de mantenedor público ou privado, sobrevive da execução dos próprios projetos. Aprendi muito sobre aquele espaço através de Kabila, que tem uma história ali há muitos anos. Segundo ele, tudo iniciou com o terreiro do candomblé. Ali era o solo sagrado onde aconteciam os rituais presididos por ele, o pai de santo Kabila. Com o tempo, antes da construção do atelier, começou a utilizar o espaço para alguns desdobramentos das suas ações artísticas. Com o tempo, o coletivo foi se formando com os integrantes do terreiro, na sua maioria artistas; e surgiu a Aruanda, termo que significa tempo, e deixou de ser um terreiro de candomblé para se tornar uma Nação Livre com outra ritualística: povos africanos, guias indígenas e o povo do oriente. É da Aruanda que a UAP se manifesta também através de ações artísticas.

Arte e sagrado são as molas propulsoras de criação, e é justamente nesse epicentro energético que acontecem todas as epifanias, os transes, catarses, a dança, performance.

Comunhão entre arte e sagrado é que traz uma alegria enorme para nós. A possibilidade de transformação da individualidade e do entorno, e todos estes 
desdobramentos potencializam muito e nos dão outra visão. É uma plataforma múltipla onde a alegria, o sagrado e o profano estão diretamente ligados com o nosso cotidiano. A produção artística é ligada ao modo de vida, à experiência. Ela é completamente viva na sua organização onde a gente vai fazer agora, é nosso chão sagrado, nosso centro energético. (mestre Kabila Aruanda).

A matéria prima das criações é através de reinserção de material e transformação de objetos em múltiplas linguagens. Além dos projetos específicos do coletivo ${ }^{48}$ existe os projetos individuais que se intercomunicam. Dentro da nação que é o terreiro e do coletivo UAP não existe o profano. - O desafio é dar conta de tudo isto. Novos monsters, performances, residências. (Kabila Aruanda)

A ritualística traz uma metodologia, e existe uma racionalidade nesta construção que é complexa. Ação, emoção e razão é nossa pirâmide, diz Bukuritós Aruanda. Todos os integrantes ganham em algum momento nos rituais, isto não é pré-concebido, um nome de batismo que é composto ao Aruanda, como se fosse um sobrenome.

A primeira ação do coletivo foram os tecidos na cerca. Existia um arsenal de objetos e tecidos que não eram mais utilizados e viraram uma marca do coletivo. A cerca virou uma instalação artística e uma curiosidade para os moradores da região. $\mathrm{O}$ espaço não é tão fácil de localizar, eu o reconheci pelos tecidos nas cercas.

\footnotetext{
${ }^{48}$ UAP - Usina da Alegria Planetária. Disponível em <https://www.uap-residence.com/> Acesso em JUL2020
} 
Outra integrante com quem tive o prazer de conviver é Gisele Peixe, Dadá Youngê, uma artista museóloga que trabalha com memória e tempo, que ressaltou a proposta da UAP - É como estarmos juntos na natureza e recuperarmos nossa potência dentro de um coletivo. A palavra Usina pressupõe transformação. Eu me vejo absolutamente cotidiana. a minha potência está no contato da natureza. O tempo e a natureza não são controlados. Axé (Dadá Youngê)

Com a convivência, fui constatando que a questão estética e artística era mais uma filosofia, uma escolha de viver integrada à arte, espiritualidade e comportamento. Era um espaço de resistência e resiliência, e a escolha era sempre revisitada por eles nos momentos de fragilidade e desistência. Comecei a enxergar o atelier da UAP como um museu orgânico, uma cenografia viva, todo o tempo te contaminando por algum lugar. Comecei a liberar algumas ações, experimentar e agir dentro dessa contaminação: arte, espírito e natureza. Passei a entender que a chuva que permanecia me proporcionava esse tempo de preparação para interferir naquele solo sagrado com a minha arte. Todas as ações que realizei, hoje considero como um rito preliminar em que fui me desligando do cotidiano e entrando no mundo da Aruanda, para depois realizar as hierofanias. Foi uma experiência profunda de arte, desconectada de técnicas e conceitos, a linguagem era ser e agir, uma performance mais orgânica. 


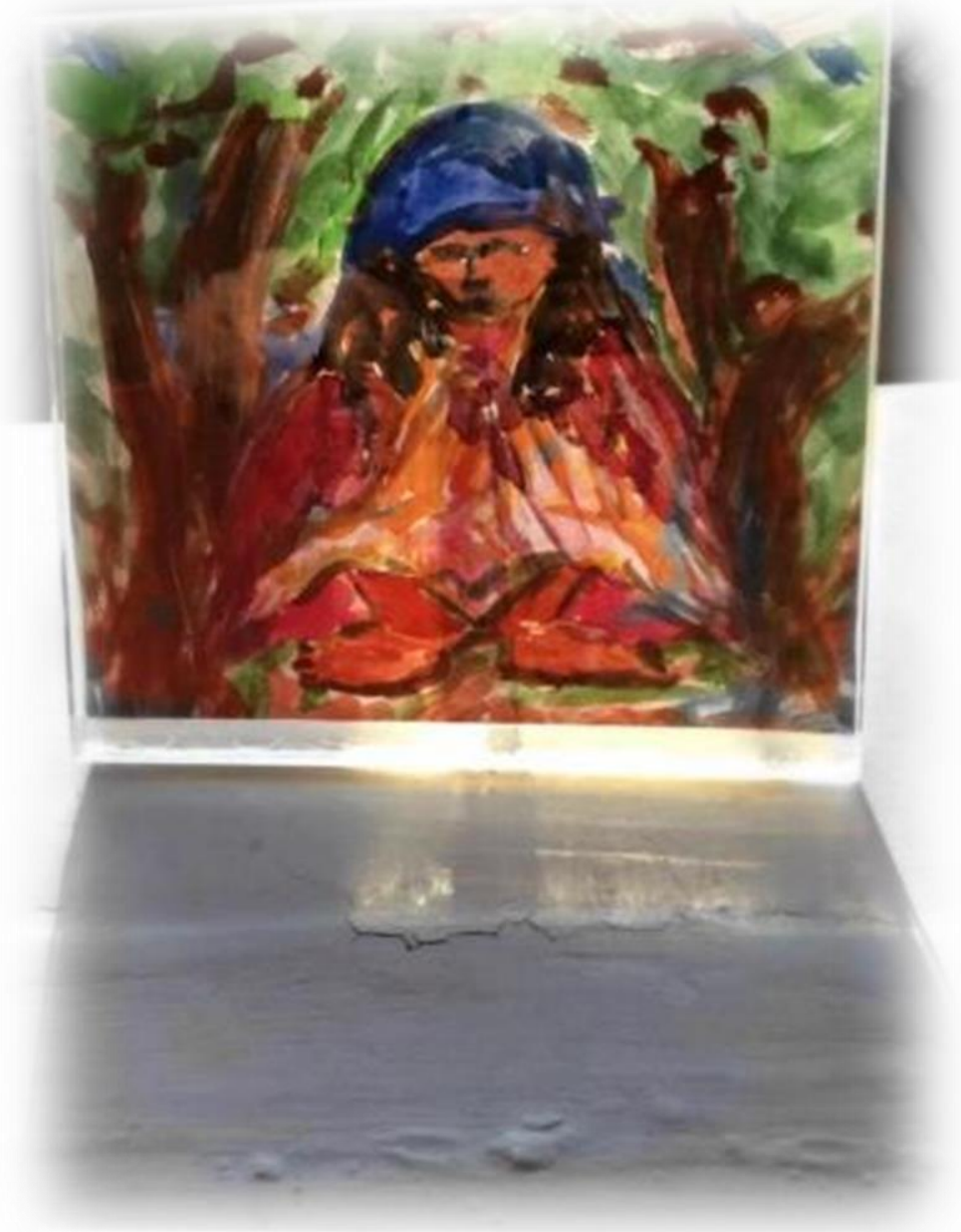


RETRATOS VIVOS

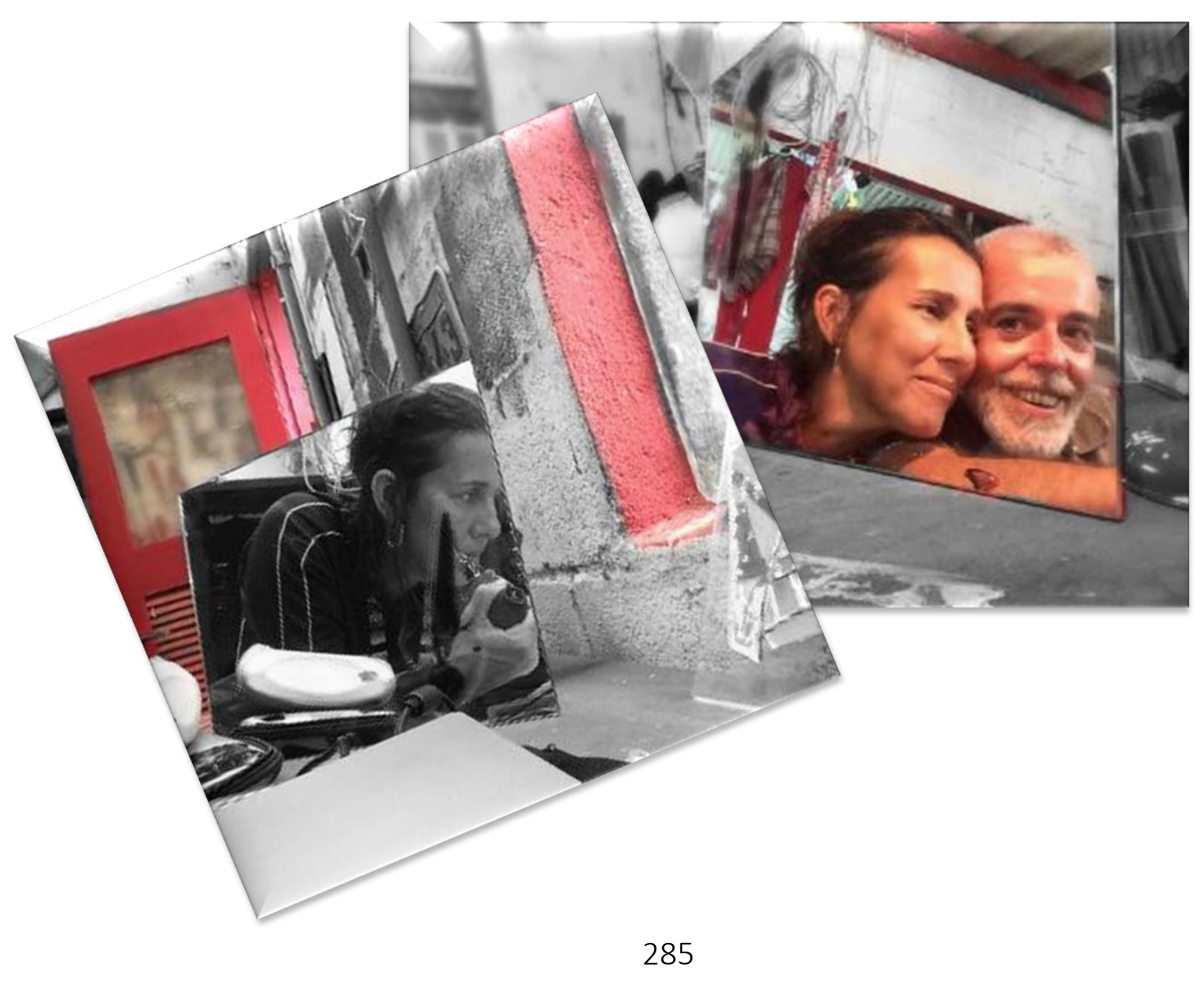


MEUS SERES






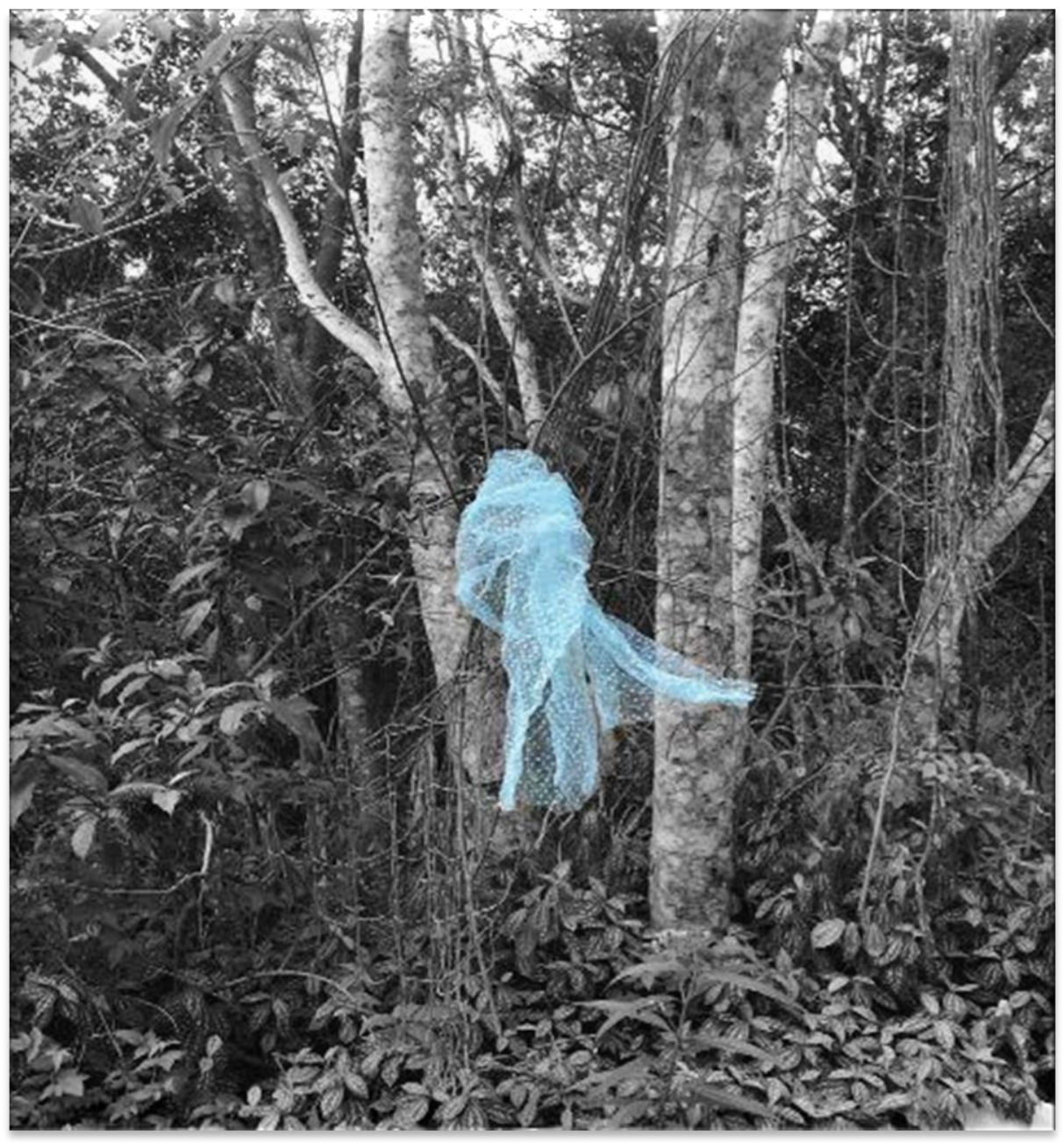




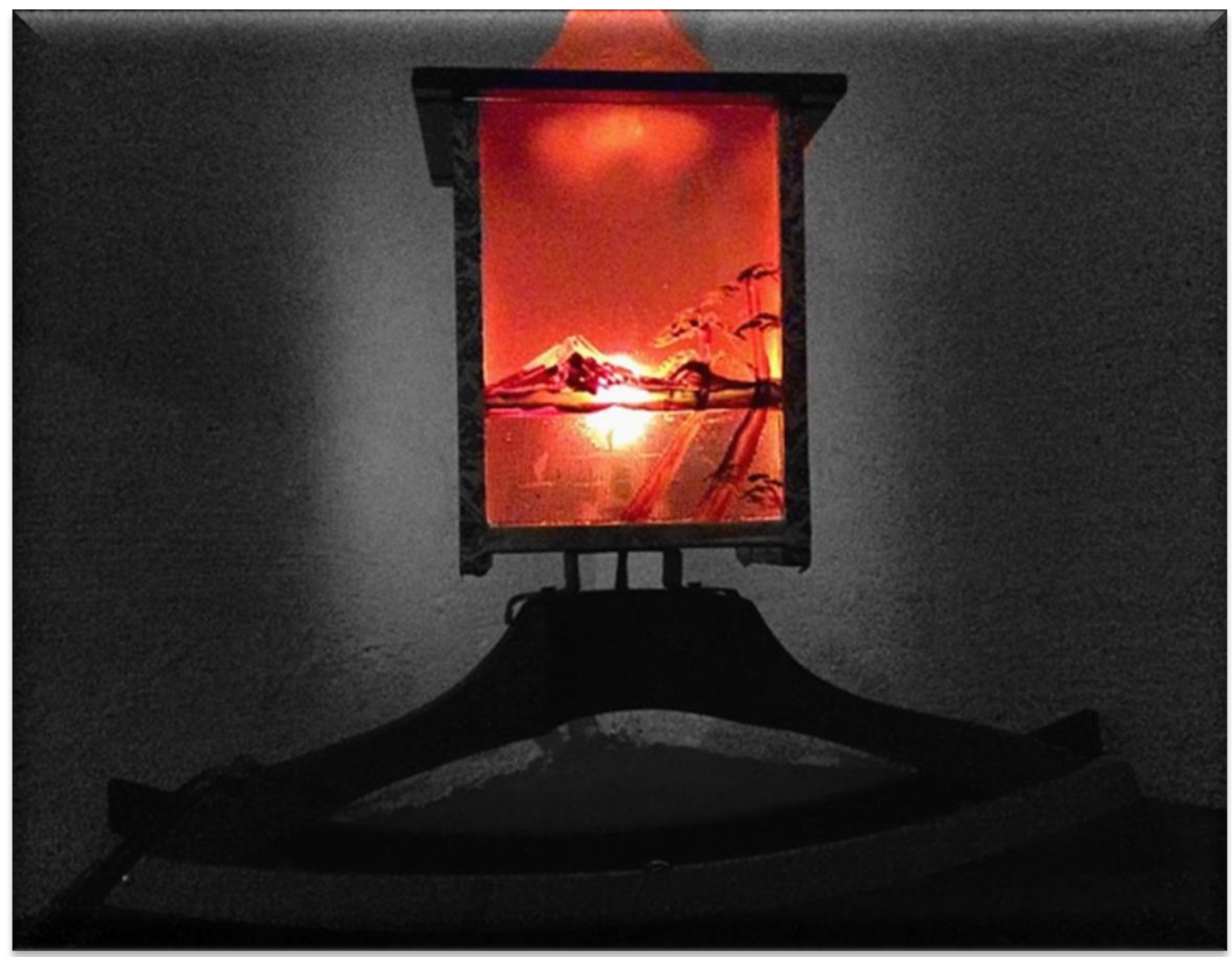


O ATELIER DA USINA

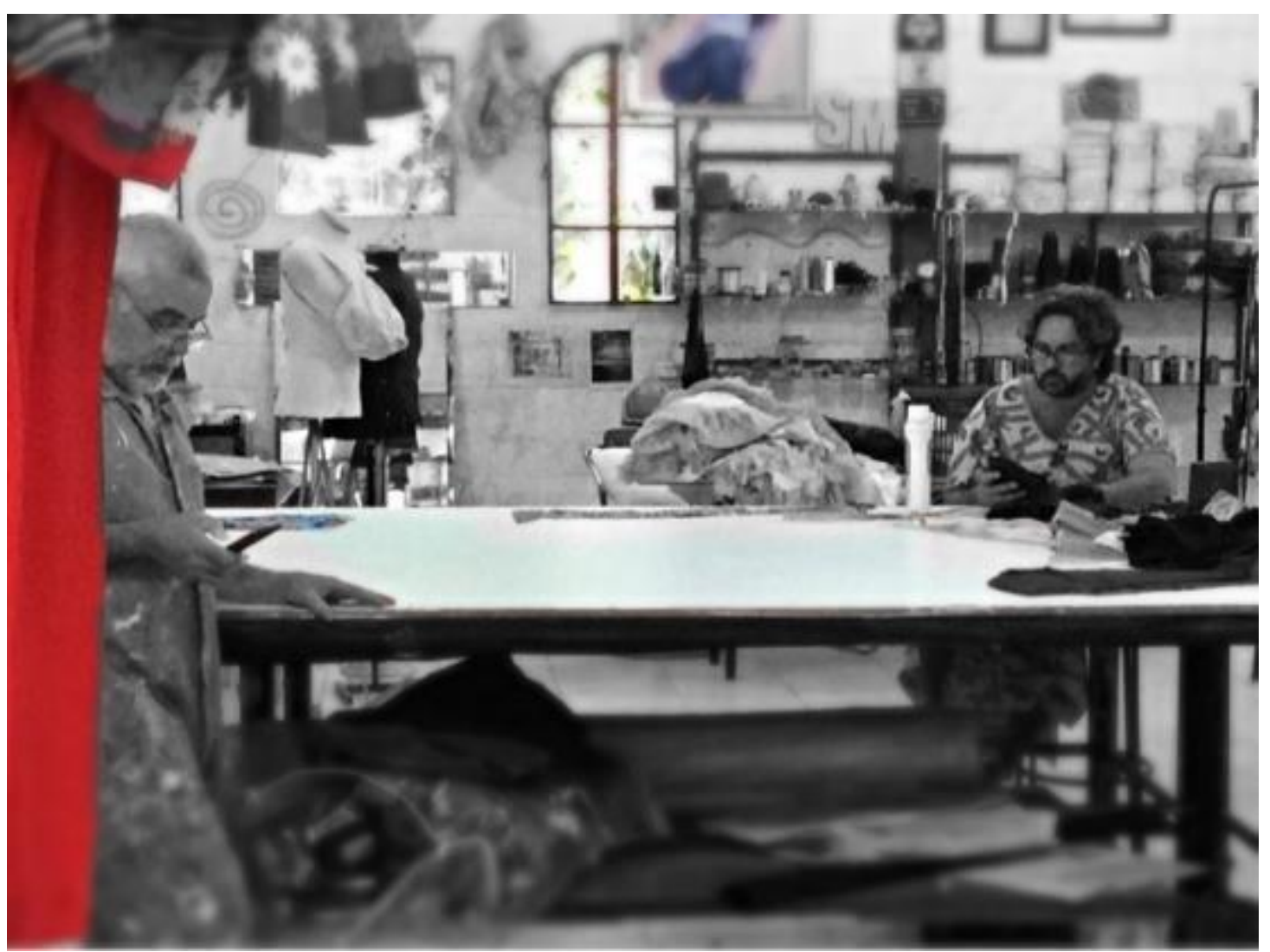




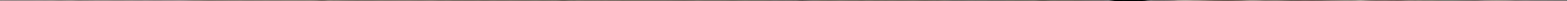









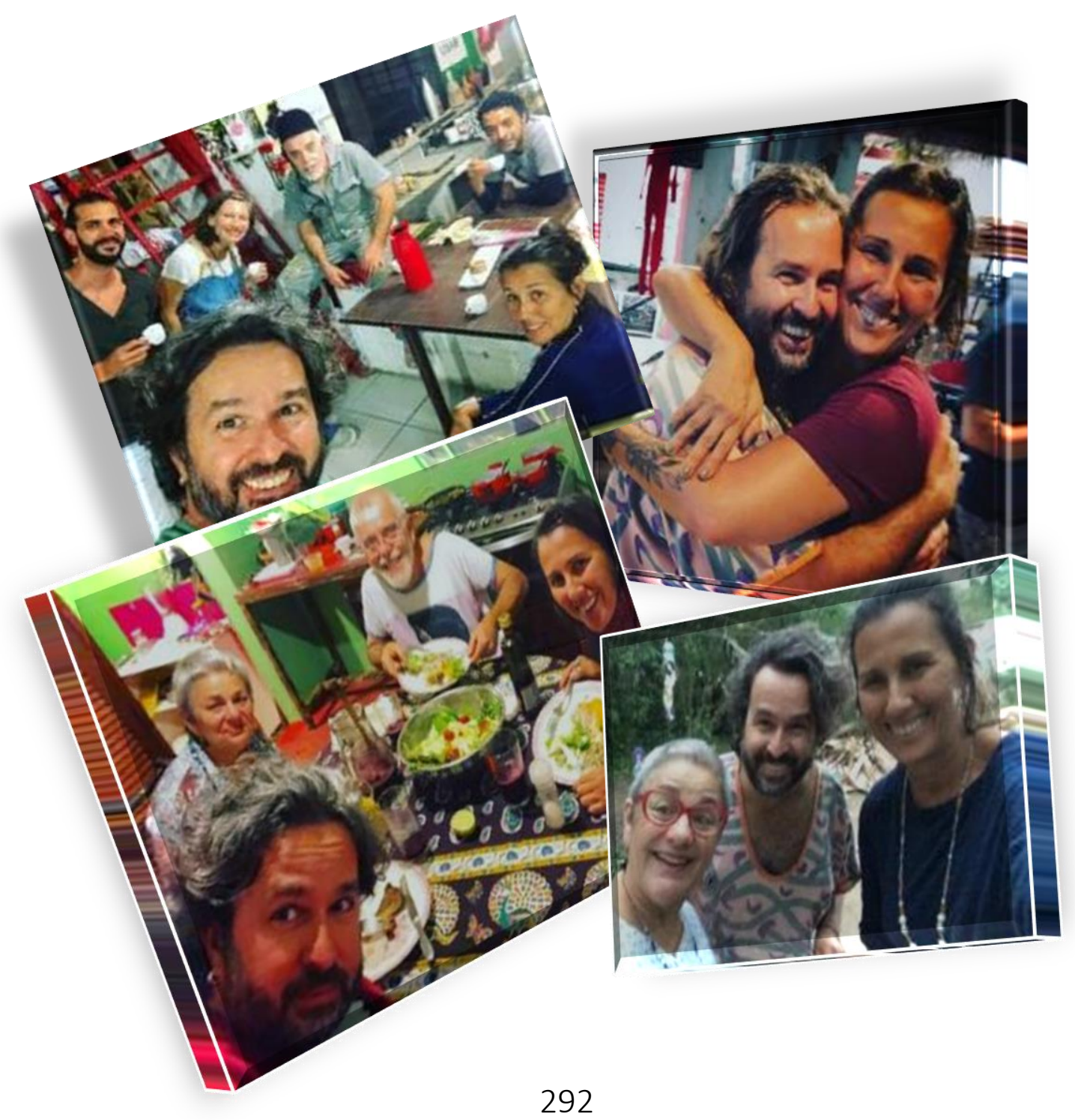


CASA DE OXUM (DADÁ YOUNGÊ)

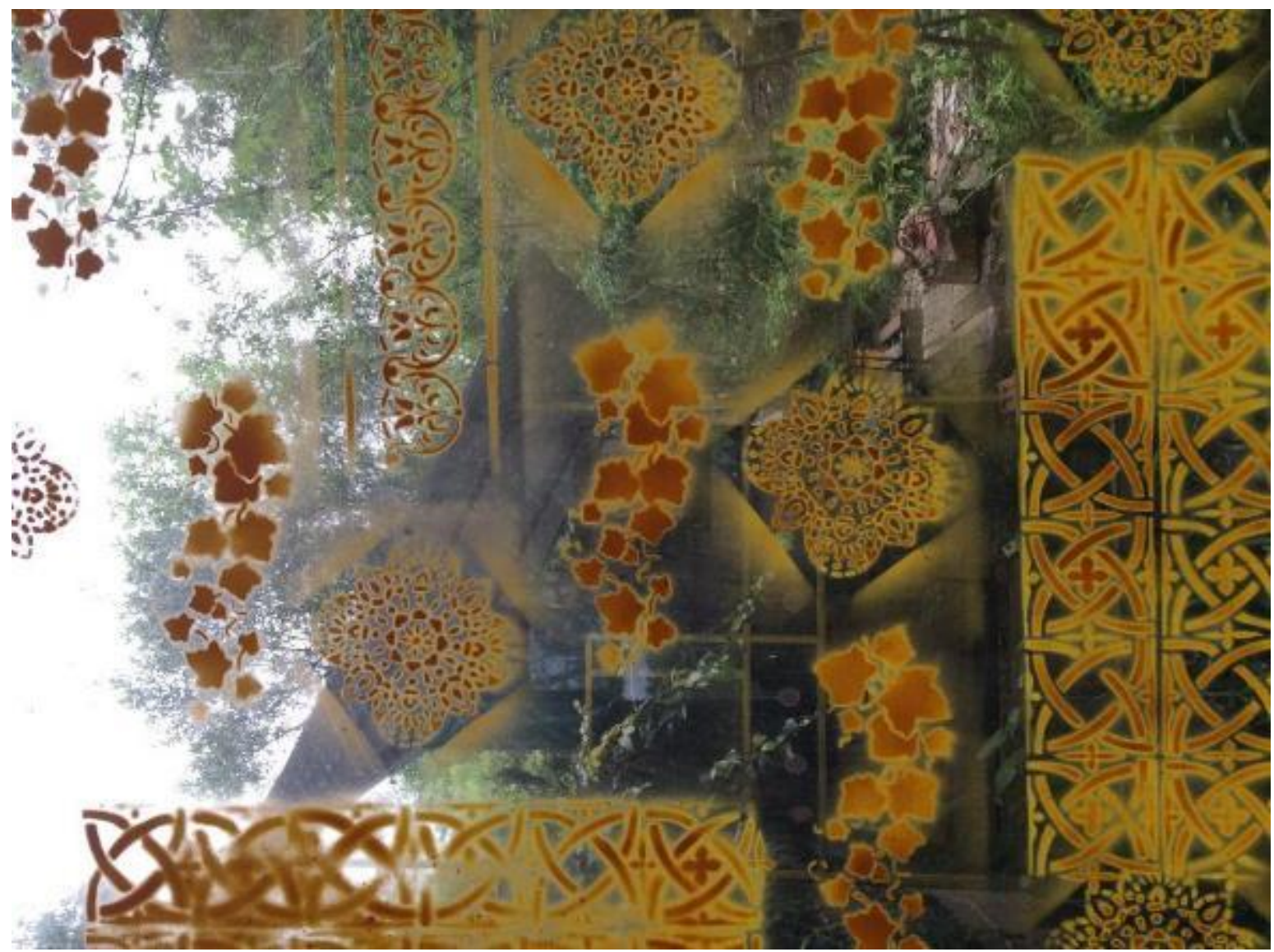




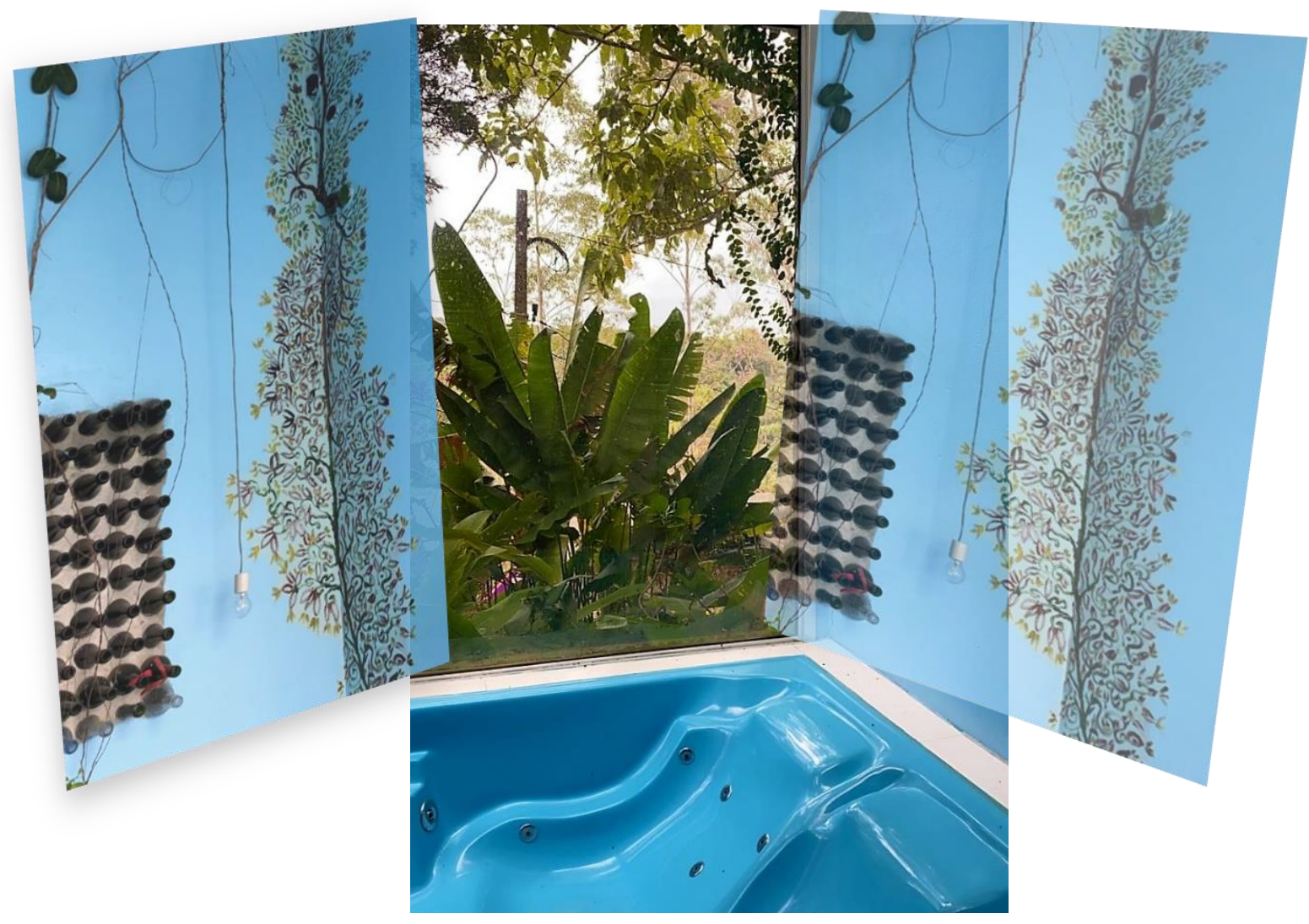


Pelas condições climáticas desfavoráveis, o mestre Kabila sugeriu que fizéssemos as hierofanias no Solo sagrado, onde eles realizavam os rituais da Aruanda, um espaço limpo e aberto sem necessidade de preparação. O espaço ficava próximo ao atelier principal, a Usina. Os acessos de um espaço ao outro se davam por trilhas na mata onde se viam instalações artísticas, entre elas os "abrigos" das entidades que eles cultuavam. Tudo sagrado. Eu frequento uma casa de candomblé de raiz, e é comum vermos os assentamentos e as casas de santo representadas em espaços individuais. Na minha roça, por exemplo, na entrada temos Exu, Ogum e lemanjá, e cada um tem seus objetos representativos referentes aos Orixás; os outros assentamentos ficam num outro local, o quarto de santo. No candomblé de raiz não existem imagens, apenas símbolos. Na Nação Aruanda era diferente, além dos Orixás havia outras entidades, e esses assentamentos estavam espalhados por toda a mata. Eram instalações orgânicas e artísticas, como templos espirituais. A leitura da ritualística não era padronizada, tinha uma abstração livre e criativa sobre a potência daquelas divindades. Portanto, o solo sagrado era apenas o espaço central onde aconteciam os rituais coletivos. Lá também, semanalmente eles queimavam o lixo. Nesse espaço estavam localizados a cozinha da roça e o quarto de santo. Na rua havia uma instalação aérea com bandeiras de tecidos que eram a marca do coletivo e atravessavam toda a área externa do coletivo.

Passados doze dias, o tempo permanecia instável, mas resolvemos iniciar a coleta de material e comprar alguns fardos de lenha na região para garantir a queima com lenha seca. Durante dois dias conseguimos ter um mínimo desejado, que conservamos coberto com 
lona. No décimo quinto dia, 23 de outubro, resolvemos arriscar e iniciar a construção da fogueira. Por conta da meteorologia, que não era animadora, em vez de realizar duas hierofanias em dias diferentes, propus que fizéssemos juntas num dia. Os performers eram o Bukuritós e o Kabila. Combinamos que iniciaríamos com Bukuritós, e estabeleceríamos um código para sua retirada e entrada de Kabila, evitando interromper os ritos liminares. A Dadá Youngê ia acompanhar os trabalhos e assumiu a posição de guardiã do fogo, com a tarefa de alimentar as fogueiras durante as performances. Diferentes para mim em relação às experiências anteriores foram o campo perceptivo e a preparação. Isto já acontecia desde minha chegada lá. Também a presença do sagrado impressa ali e dentro deles reverberava em mim. Segui com as operações metodológicas, montei as fogueiras durante o dia sozinha. O Kabila, por alguma razão que eu desconhecia, disse que eu poderia incluir as instalações aéreas na queima, já que elas cruzavam o espaço, e solicitou que eu usasse o lixo que eles tinham acumulado como combustível. Essas informações agregadas a meu método de montagem trouxeram uma estética curiosa em forma de tenda. Montei a fogueira maior no centro dos cordões de tecidos e soltei as extremidades, deixando suspenso apenas na área central. O lixo, que era composto de papelões, caixas de mantimentos, papel usado etc., compunha uma das camadas intermediárias. Os fardos de lenha eram a sustentação. A outra fogueira, bem menor, se localizava atrás, a uns 6 metros de distância, e utilizei uma telha com tijolos para erguer e ter outra perspectiva no enquadramento da câmera, truques que se aprendem no ofício de iluminador. 


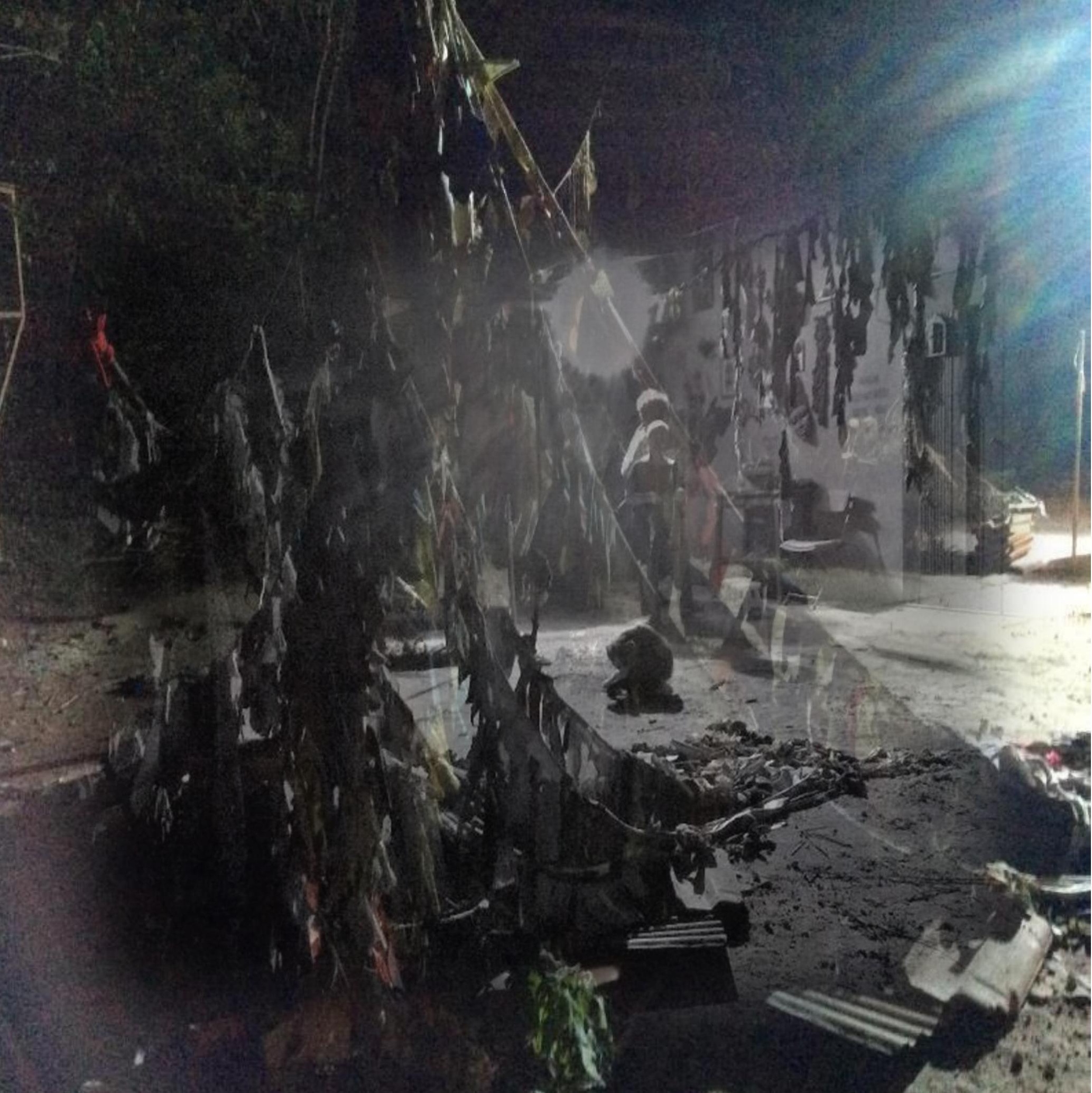




\section{HIEROFANIAS 6 E 7 - O Solo Sagrado}

Local: Usina da Alegria Planetária - UAP

Município: Cotia/SP

Carta do trabalho: Carta 36 - Seres do Trovão

Acendendo fogo: $19 \mathrm{~h} 05 \mathrm{~m}$

Final do trabalho: não foi anotado

Câmera 1. Cláudia de Bem (pesquisadora) Carta 9 - Escudo do Sol

Lente: 70/20mm aberturas 2.8 macros

Performer: Bukuritós Aruanda. Carta 28 - Sacola de Talismãs

Performer: Kabila Aruanda. Carta 4 - Cerimônia do Peiote

Guardiã: Dadá Youngê Aruanda. Carta 2 - Tenda do Suor

Cães: Macumba e Pamela 


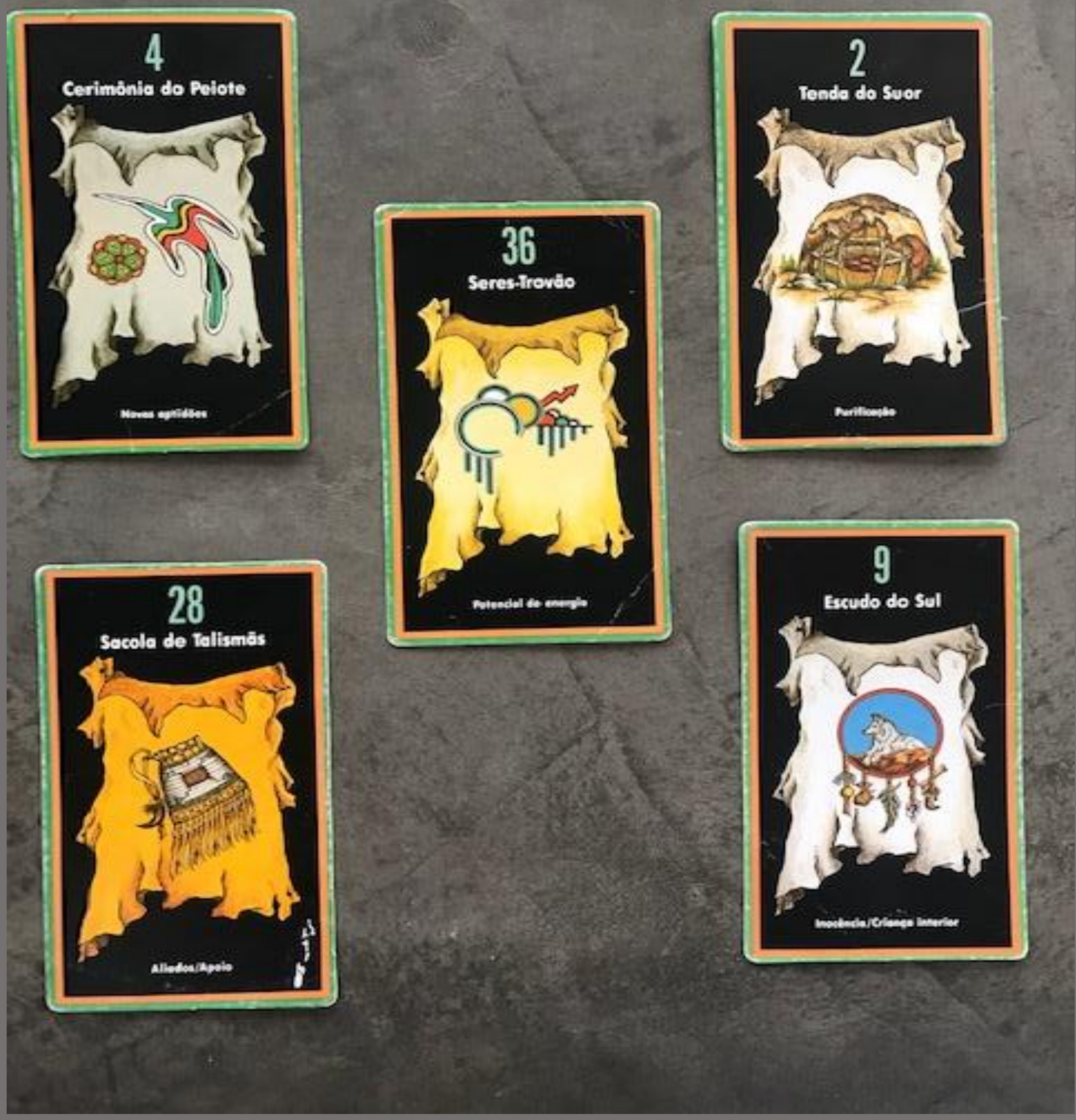


ORÁCULO

SERES DO TROVÃO

O fogo dos Céus

Energia para a mãe terra, criação divina

Voa,

Rasga o ar

Chega até nós Choque elétrico

Que nos transforma

Trazendo a verdadeira essência

Do amor

Da volta

Aos nossos corações 


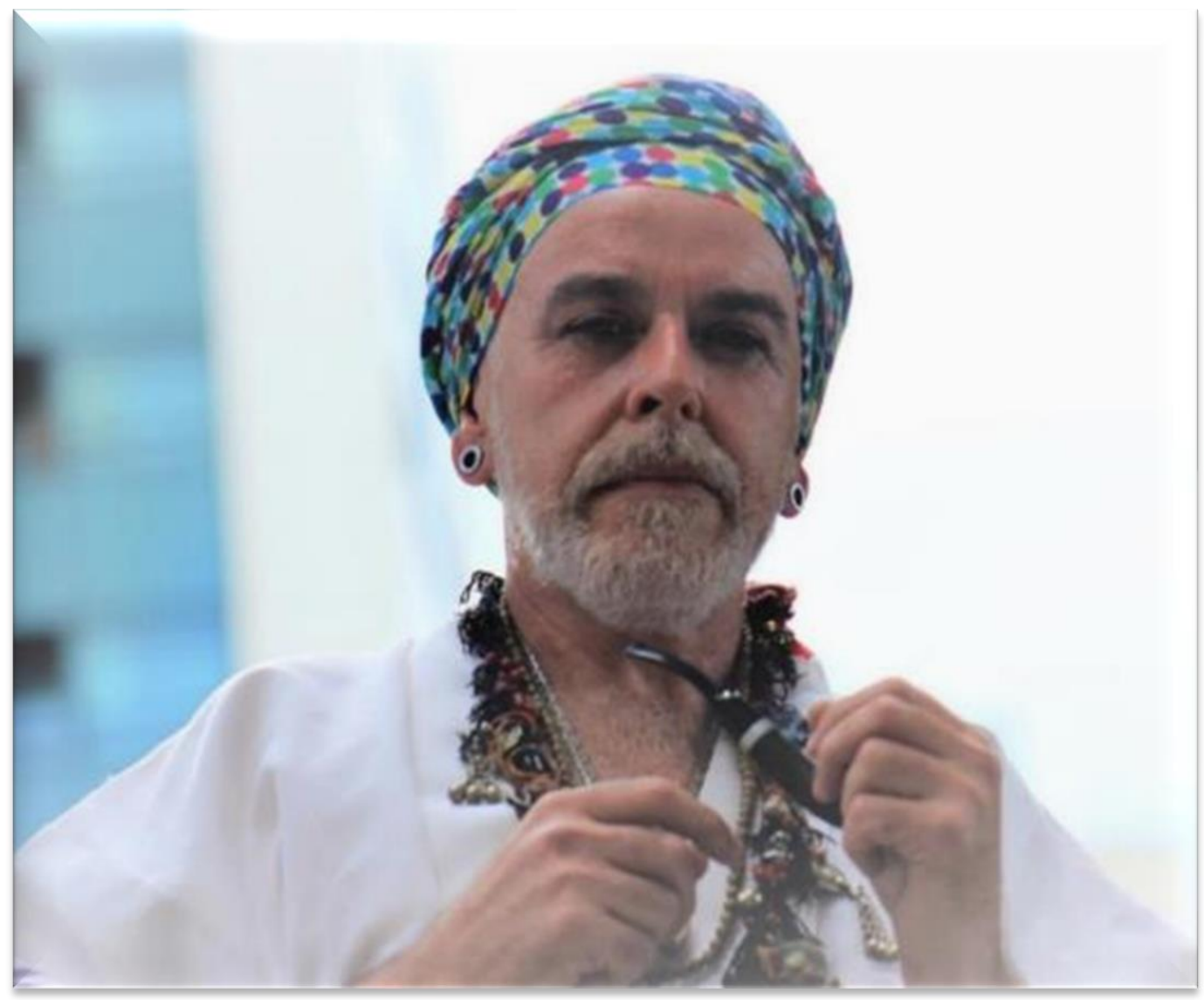

Crédito da foto: a autora 
PERFORMER: KABILA ARUANDA

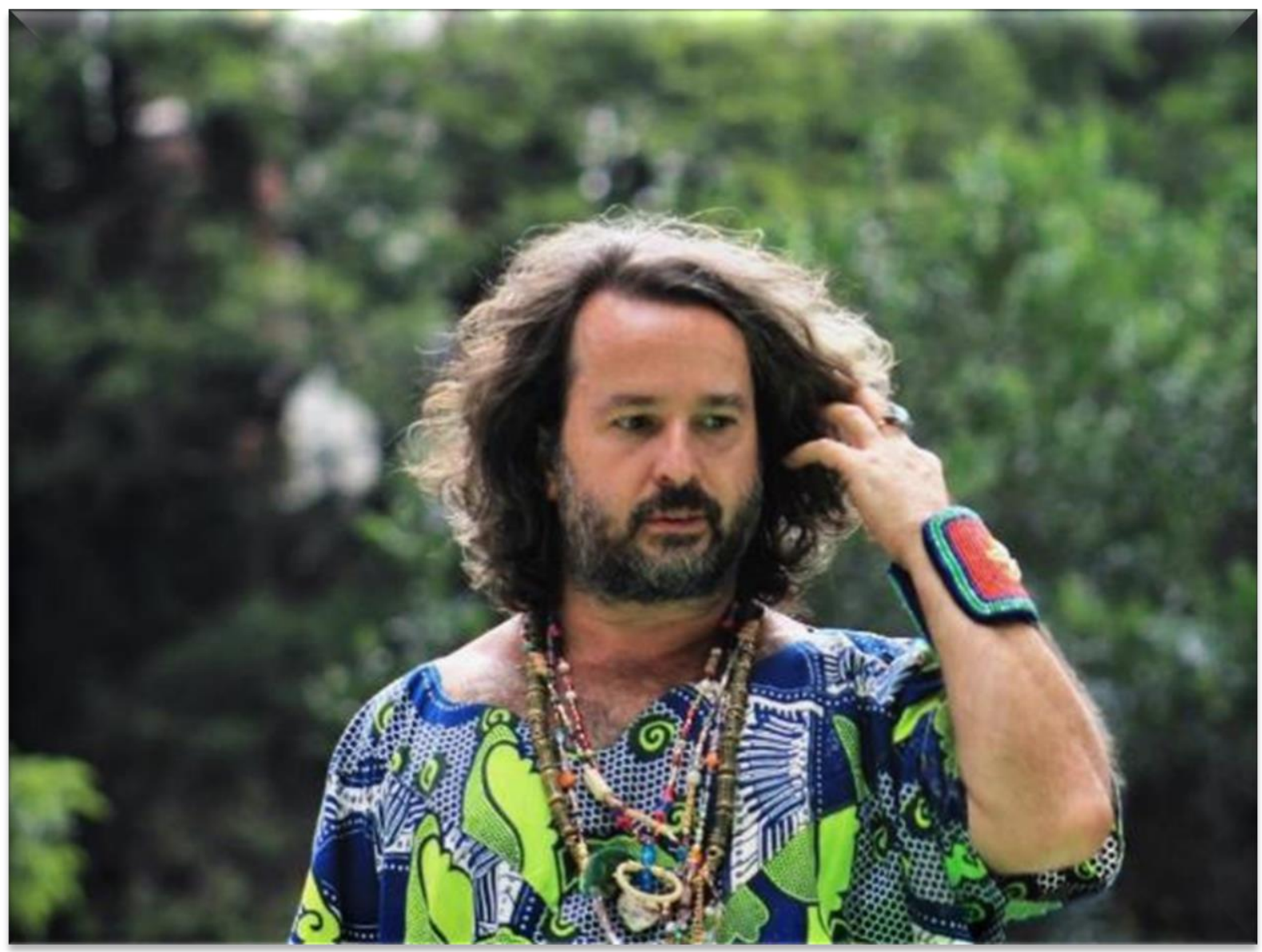

Crédito da foto: a autora 


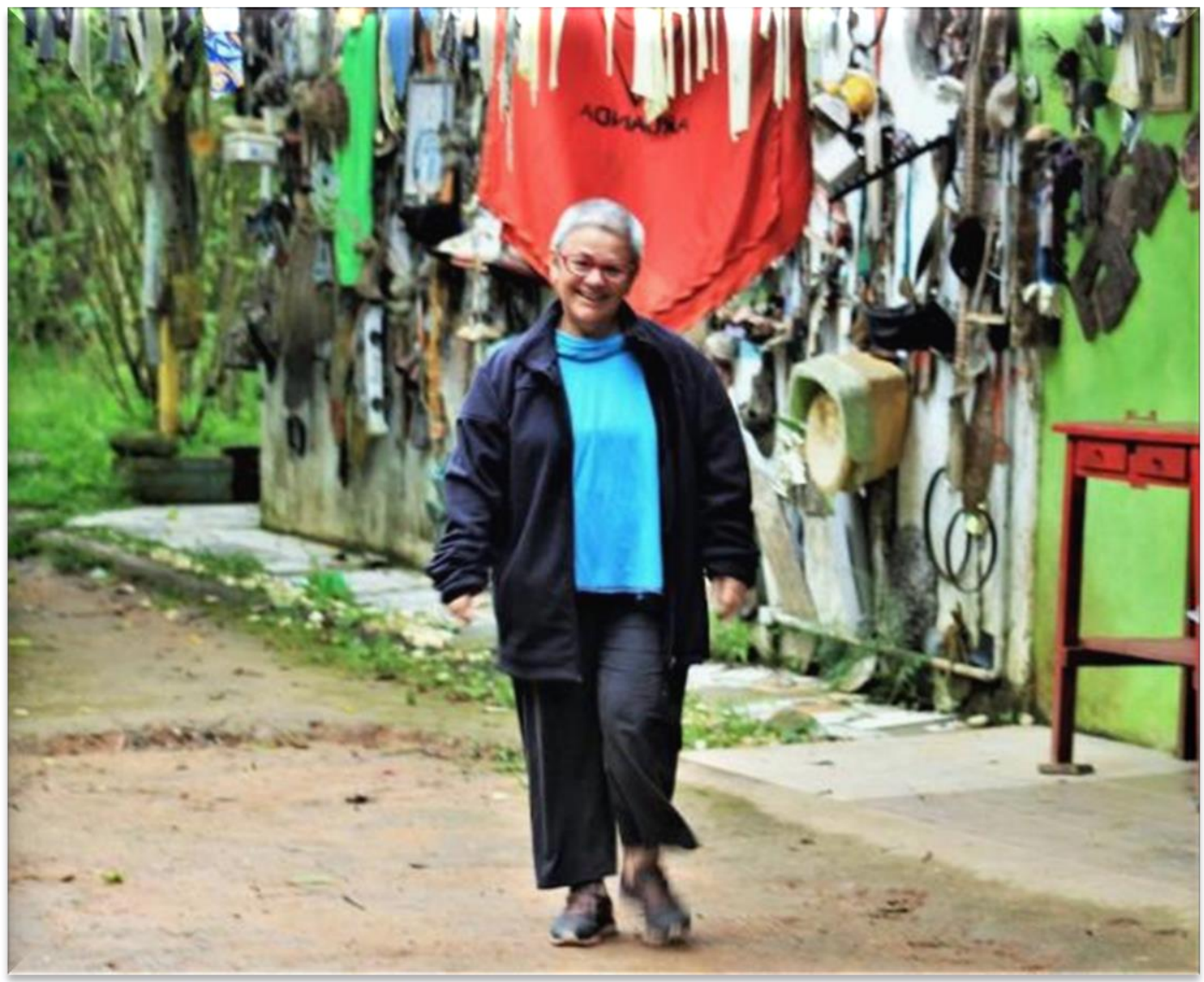

Crédito da foto: a autora 
Diferente do estado preparatório das outras hierofanias, talvez por ter sido tão intenso e longo, senti a necessidade de usar uma indumentária. Os integrantes do coletivo, no seu cotidiano, usam vestes diferentes feitas pelo mestre Kabila, quase como uma grife. São panos soltos e confortáveis, batas coloridas que remetem aos caftans africanos, e no pescoço trazem suas guias espirituais, os colares de poder. Eu havia trazido os meus e a eles juntei alguns acessórios, como que vestindo uma persona mais rústica, selvagem, assim como me sentia.

Nos encontramos no final da tarde. Kabila foi o primeiro e me presenteou com um colar de poder que havia feito para mim. Ao colocar, senti como uma guia de proteção e um elo entre eles. No campo perceptivo, havia uma camada densa, uma presença invisível. A sensação era de ritual místico, como uma cerimônia religiosa. Já ao anoitecer, chega Youngê, a guardiã do fogo, e por último Bukuritós com sua indumentária brilhante branca; no meu imaginário, era a personificação de uma divindade e trazia consigo alguns objetos. Percebi todo o estágio preparatório do performer. Estava no corpo, nas vestes e na maquiagem, nada excessivo, tudo essencial, orgânico. Falamos o básico sobre os procedimentos iniciais, o código para a saída de Bukuritós e entrada de Kabila, o alimento do fogo, atribuição de Youngê, e o acendimento com as tochas, a retirada do Oráculo.

Farei um único relato sobre os dois performers por entender que foi uma única hierofania, uma fogueira e uma consulta ao Oráculo.

Nessa noite compreendi mais sobre performance. O Ser, o fazer e o agir. 
Juntos, cada qual num hemisfério, acendemos o fogo naquela tenda que lentamente foi se desmanchando. Eram histórias daquele espaço que se juntavam à chama, um fogo colorido com componentes da existência daquele coletivo. Assumimos nossas posições e o espaço era de Bukuritós.

Com meu olho me transportei para o mundo de Bukuritós. A relação que ele estabelecia com o fogo era integrada, um corpo, um espírito e a luz sagrada. O corpo, como instrumento da ação artística na hibridez entre as linguagens do teatro, da dança e das artes visuais, agia de forma ritualística com o elemento, semelhante a uma cerimônia de purificação. Existia organicidade nas ações e nos objetos trazidos para a performance, uma bacia com sal, pedras, plantas, utilizados numa ordem específica, organizada etapas de um ritual. Houve um momento em que assumiu um estado meditativo e religioso, uma relação do espírito com o Cosmos através da contemplação do elemento. Aos poucos ele se despia, entregando as vestes ao fogo e assumindo um estado puro, como se deixasse ali na chama uma persona. A performance, por si só, evidenciava o repertório do performer, suas crenças e relações com o elemento. Toda a experiência adquirida na convivência com o coletivo sobre as relações de arte, espírito e ação se transformavam em imagens da sacralização da luz e sua cosmogonia, fundamentando o corpus da tese, a luz como substância e representação de uma ideia.

Foi nessa, dentre todas as experiências, que toda minha atenção ficou no acontecimento. Não pensei em registros fotográficos ou recortes de câmera, 
simplesmente me entreguei a olhar a performance. A retirada de Bukuritós foi invisível, somente me dei conta com a entrada de Kabila surgindo na imagem, como um ser primitivo, pré-histórico na aparência. Literalmente despido e em sintonia com a atmosfera criada por Bukuritós, ele tomou o centro do espaço e se colocou numa posição meditativa, como se pedisse permissão àquela luz sagrada, e com esta ação estabelecia conexão. Aos poucos, ele se ergue e assume a ação de nutrir o fogo, utilizando os materiais disponíveis no espaço. Sempre deixo material à mão para abastecer a chama, como galhos, lenha, folhas etc. Surgia uma manifestação de força e potência do fogo com aquele corpo pela energia das ações de Kabila, tinha algo de selvagem e rústico na qualidade daquele corpo. Ele arrastava galhos grandes e pesados para a fogueira. A chama alta verticalizada performava com a ação e percebi em alguns momentos um enfrentamento entre o performer e o fogo, uma relação de domínio com o elemento, masculino. Continuamente nesta ação, vinha do performer uma sonoridade em forma de mantra estabelecendo relação profunda com a experiência. O mantra preenchia o espaço reverberando no estado corporal assumido por Kabila e no nosso estado, meu, de Bukuritós e de Youngê, nos contaminando a ponto de entrarmos espontaneamente na performance. Todos lentamente começamos a repetir o mantra e, numa ação coletiva, assumimos a mesma ação de Kabila, configurando outra performance. Na evocação do mantra, sem nenhum contato verbal, íamos realizando a queima de todos os materiais, numa ação de limpeza e purificação do espaço. O fogo começava a exercer esse sentido, 
e isto foi compreendido por todos pela força do mantra. A duração foi exatamente o tempo em que a chama virou brasa e, com ferramentas, íamos espalhando as brasas pelo espaço sagrado da Aruanda até o fogo não existir mais. Foi uma cerimônia de purificação e limpeza do espaço que finalizou com uma defumação, prática muito comum em rituais religiosos. Aos poucos nos juntamos e compartilhamos uma refeição com os alimentos (raízes, leguminosas) que, antes de iniciarmos as hierofanias, tinham sido colocados no fogo envoltos em papel laminado, e trocamos impressões sobre o acontecimento.

Não falamos sobre as experiências individualmente, e sim sobre o acontecimento em si, a cerimônia de purificação do solo sagrado da Nação Aruanda que, para eles, teve um significado relevante no histórico e processo que o coletivo atravessava.

Em particular, Kabila me entregou um nome de batismo Geyuhawa que, segundo os guias por ele acessados durante a performance, provinha de uma linhagem indígena xamânica da Sibéria e significava "pau de fogo", espíritos que comandavam cerimônias de purificação nas tribos. Pesquisei sobre esta origem, mas nada encontrei a respeito. Incorporei Geyuhawa como uma conexão sagrada da luz que reconheço em mim e se faz tão presente na pesquisa. A residência na UAP não só consolidou o entendimento sobre a sacralidade da luz, mas trouxe uma aprendizagem sobre arte, vida e lazer convivendo como uma manifestação de existência.

No outro dia parti da Aruanda com a Geyuhawa e o caderno laranja de volta ao mundo profano com as palavras de Bukuritós: Viva a sua existência 


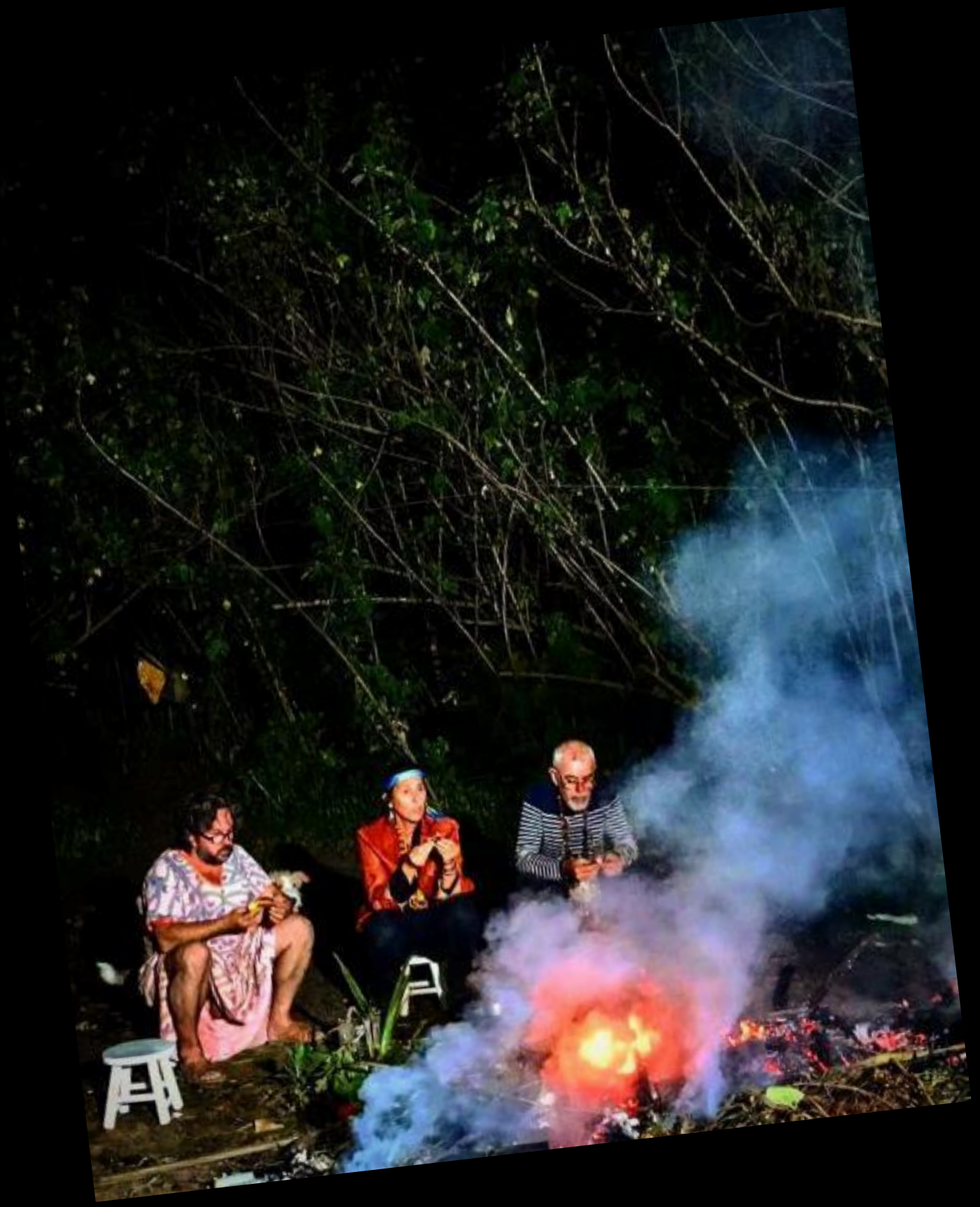




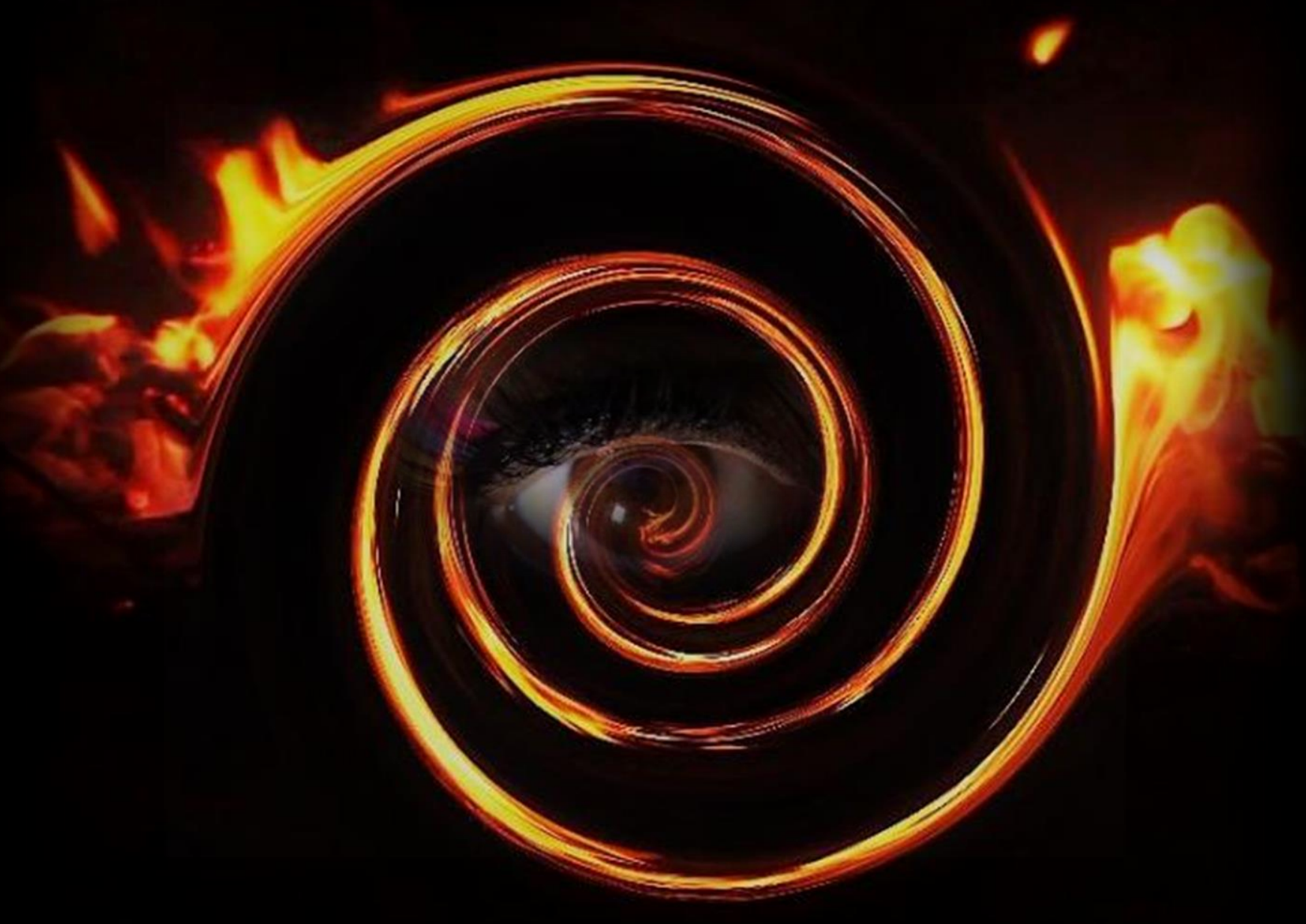




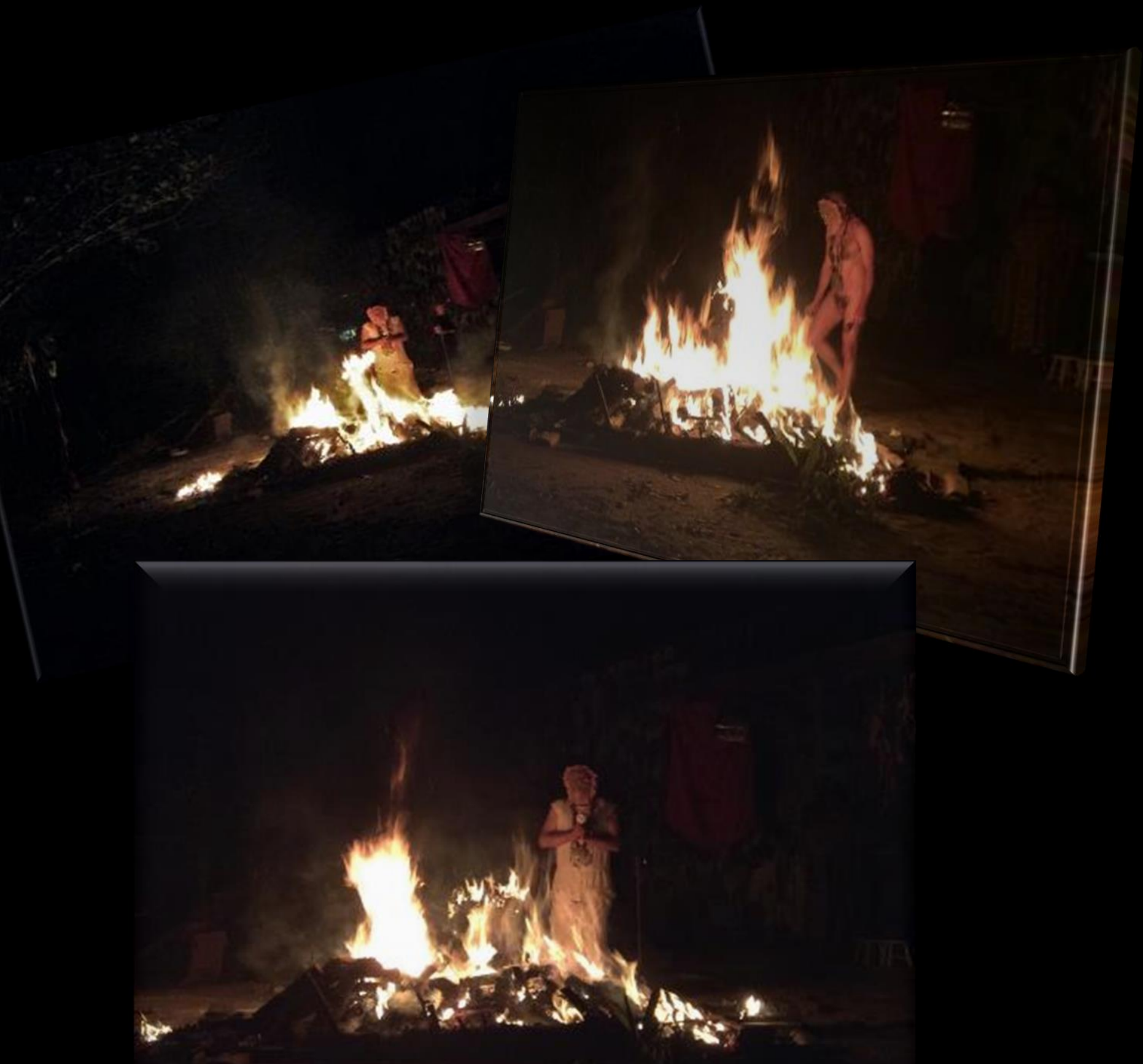




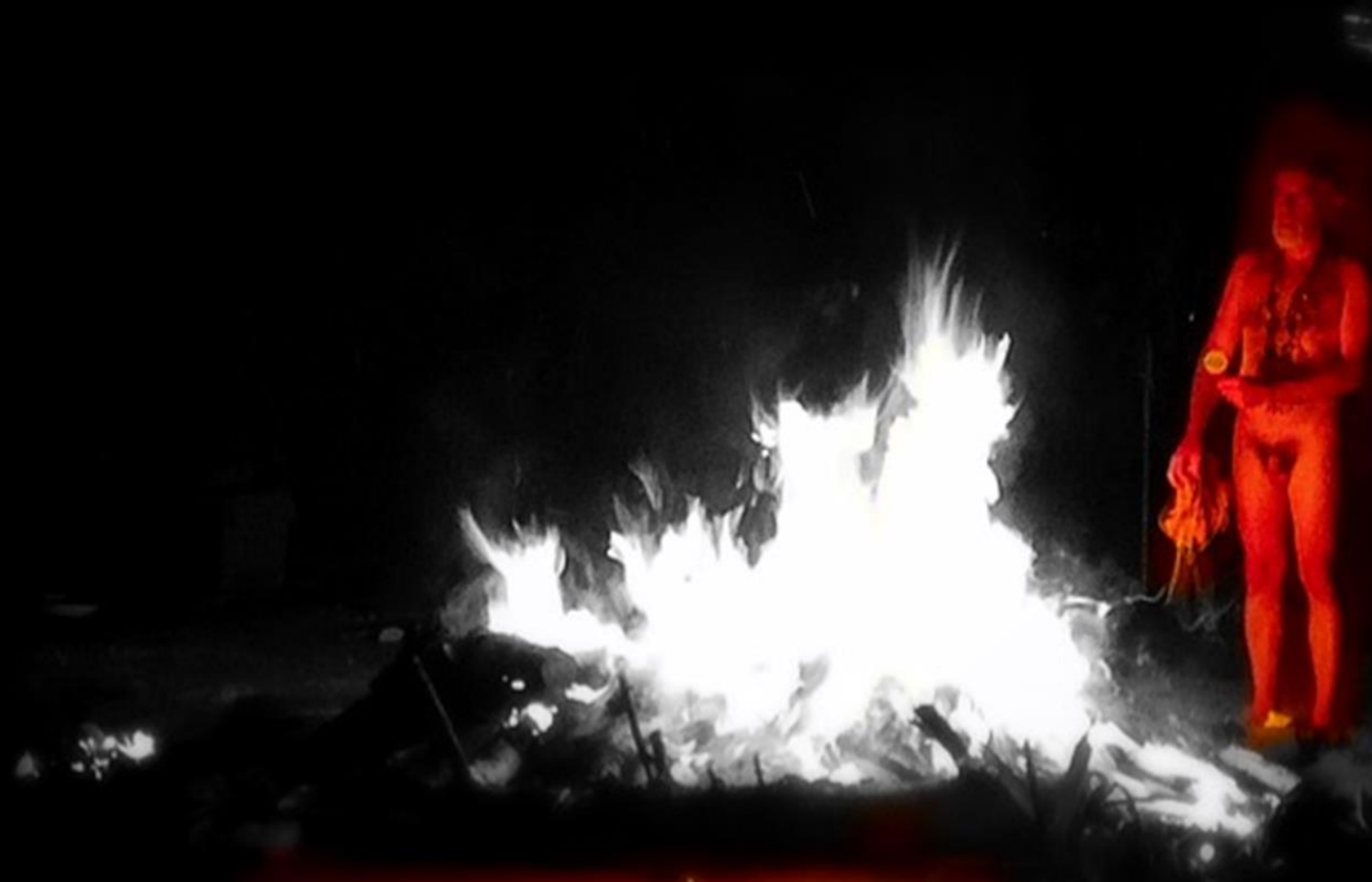




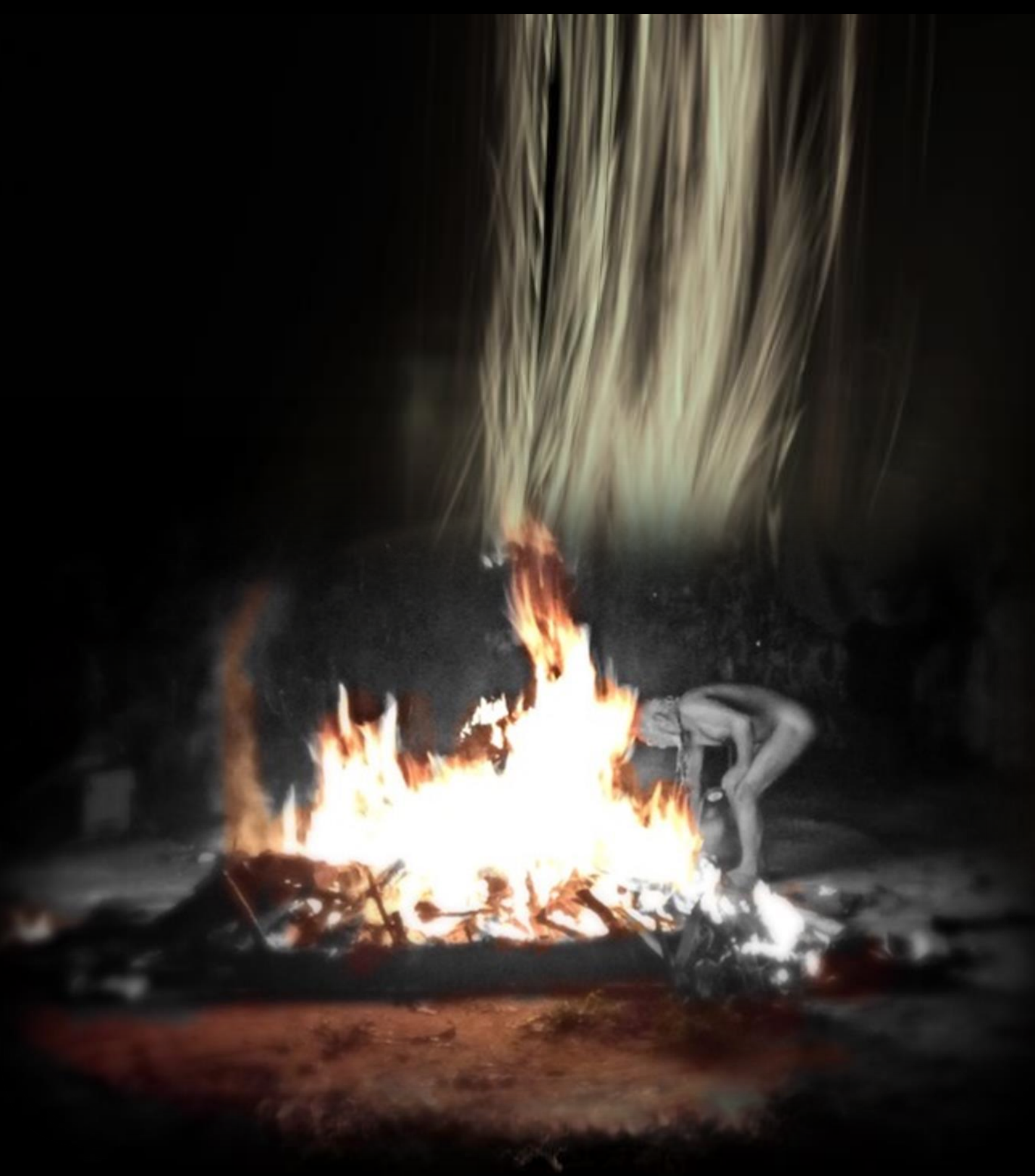


RELATOS DE BUKURITÓS

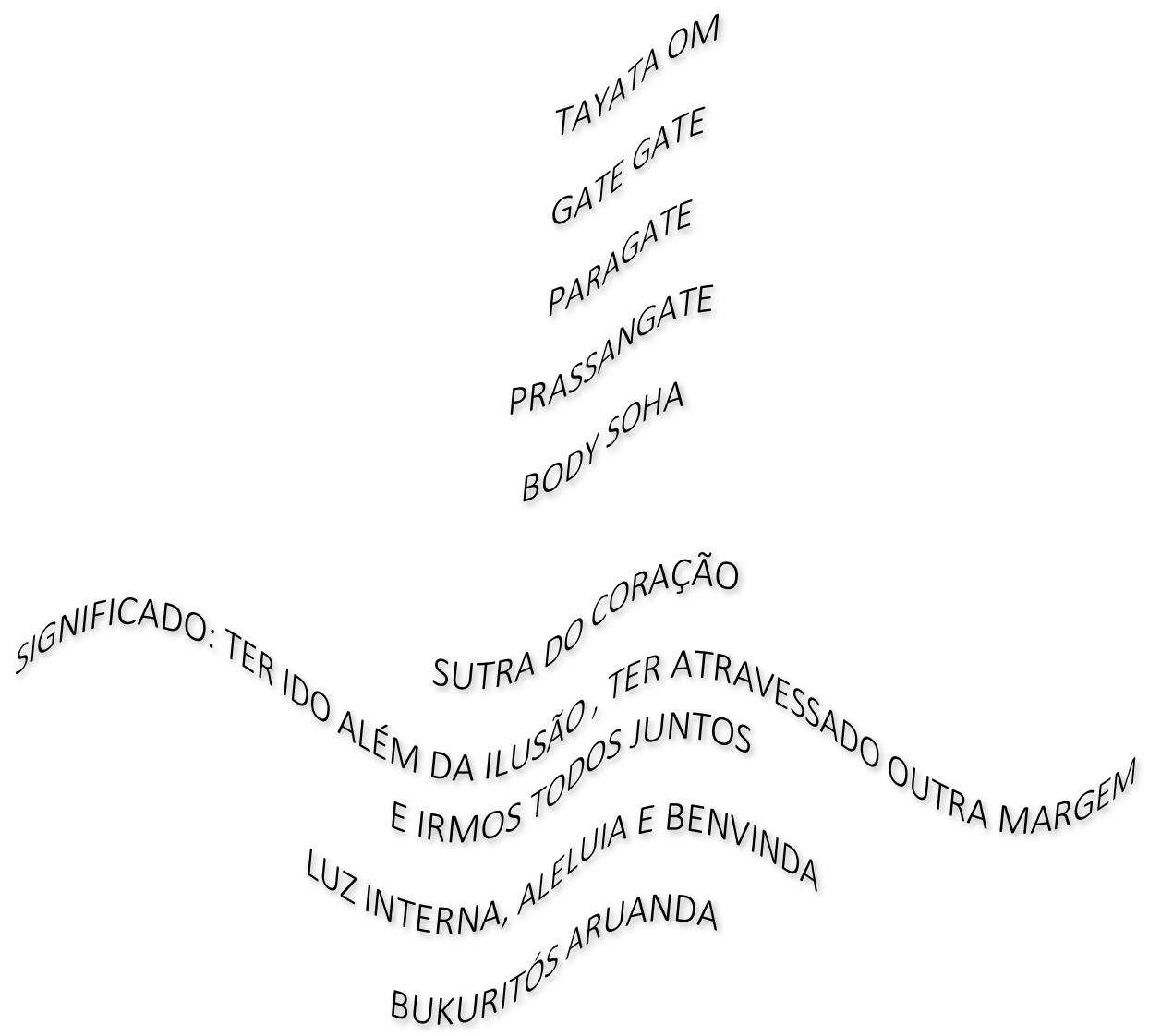

313 


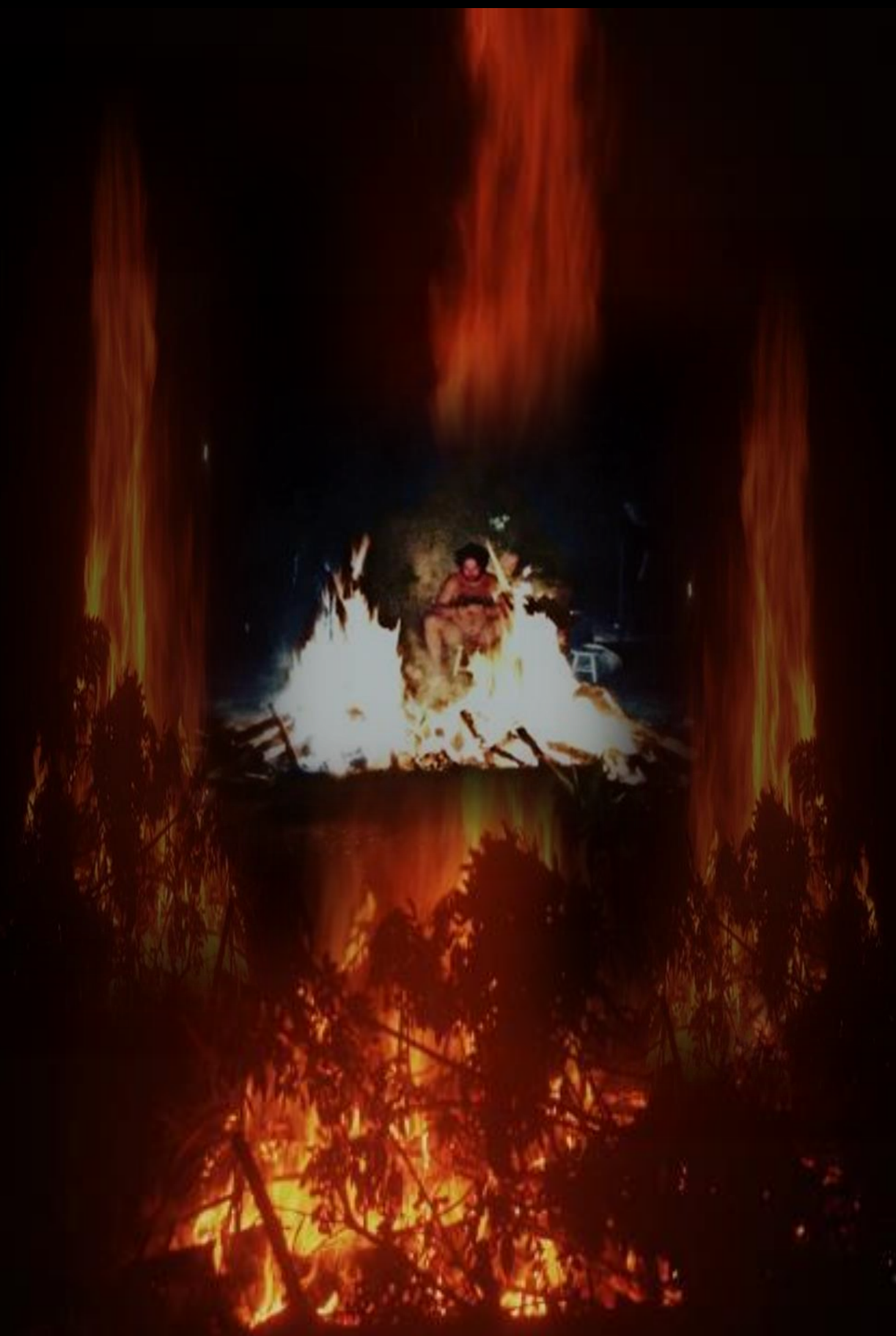


RELATOS DE KABILA ARUANDA

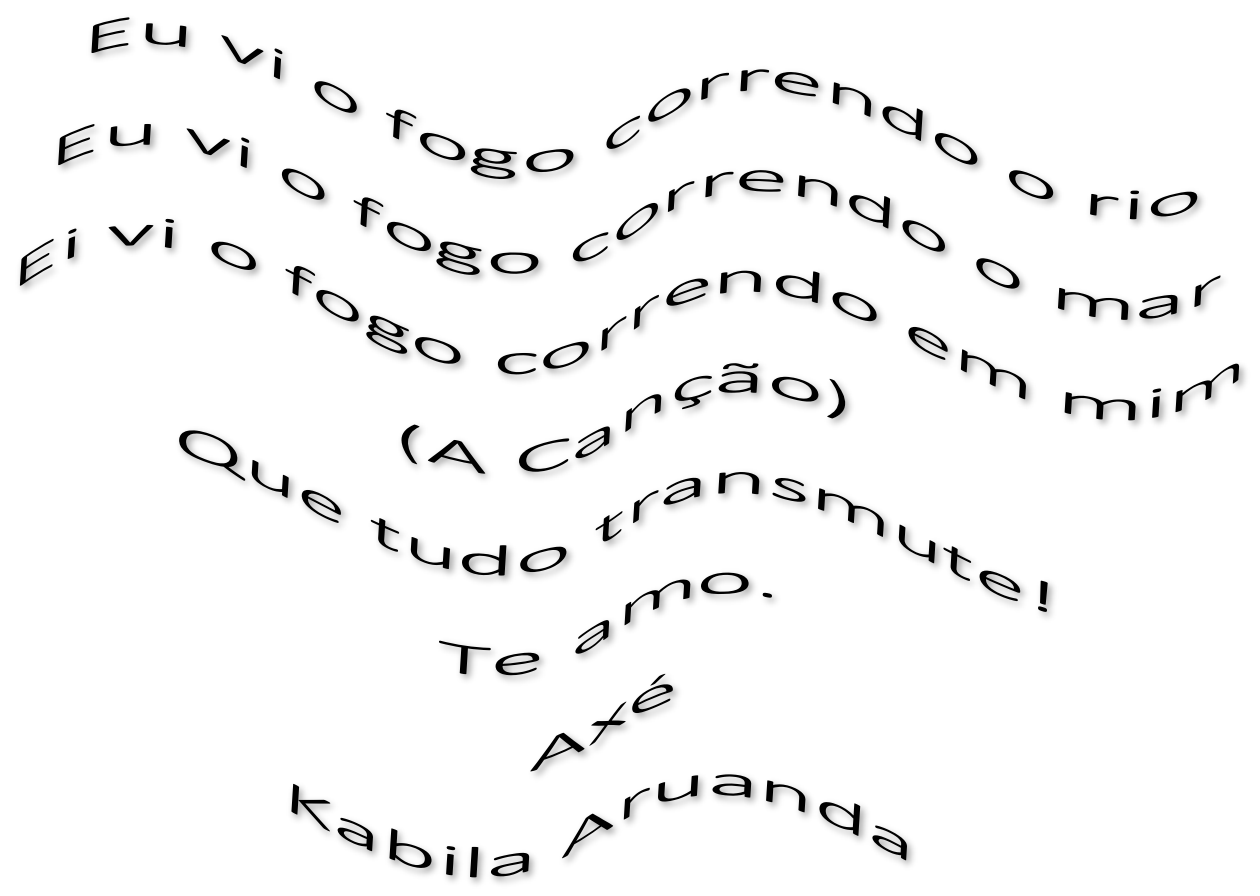

315 
RELATO DE DADÁ YOUNGÊ

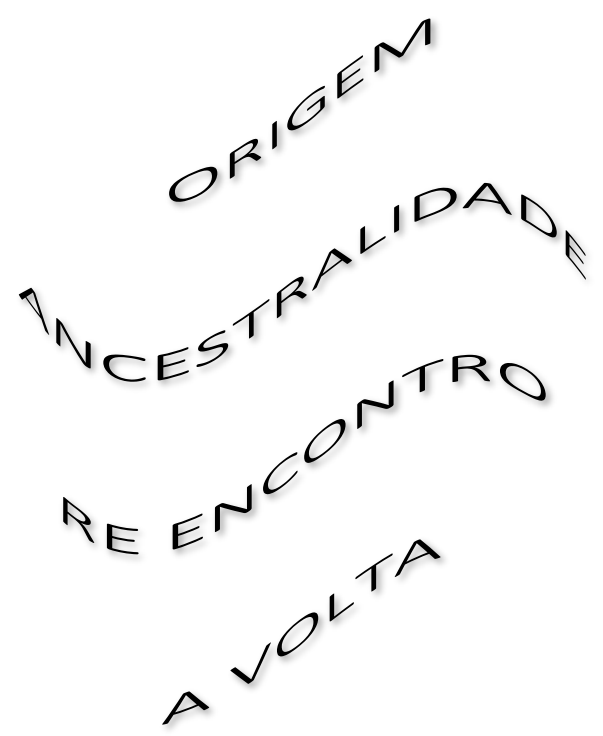

316 


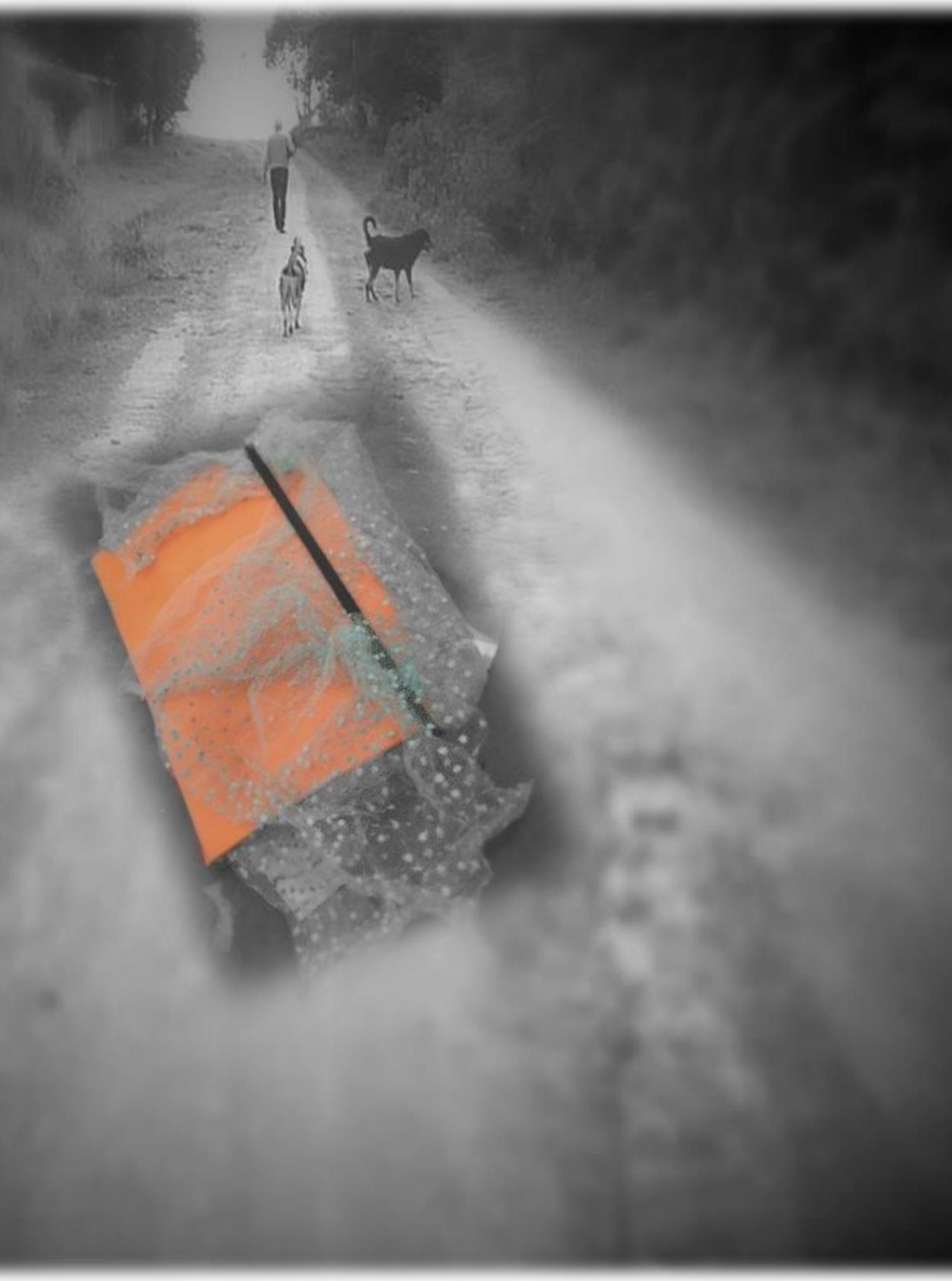


PAUSA...

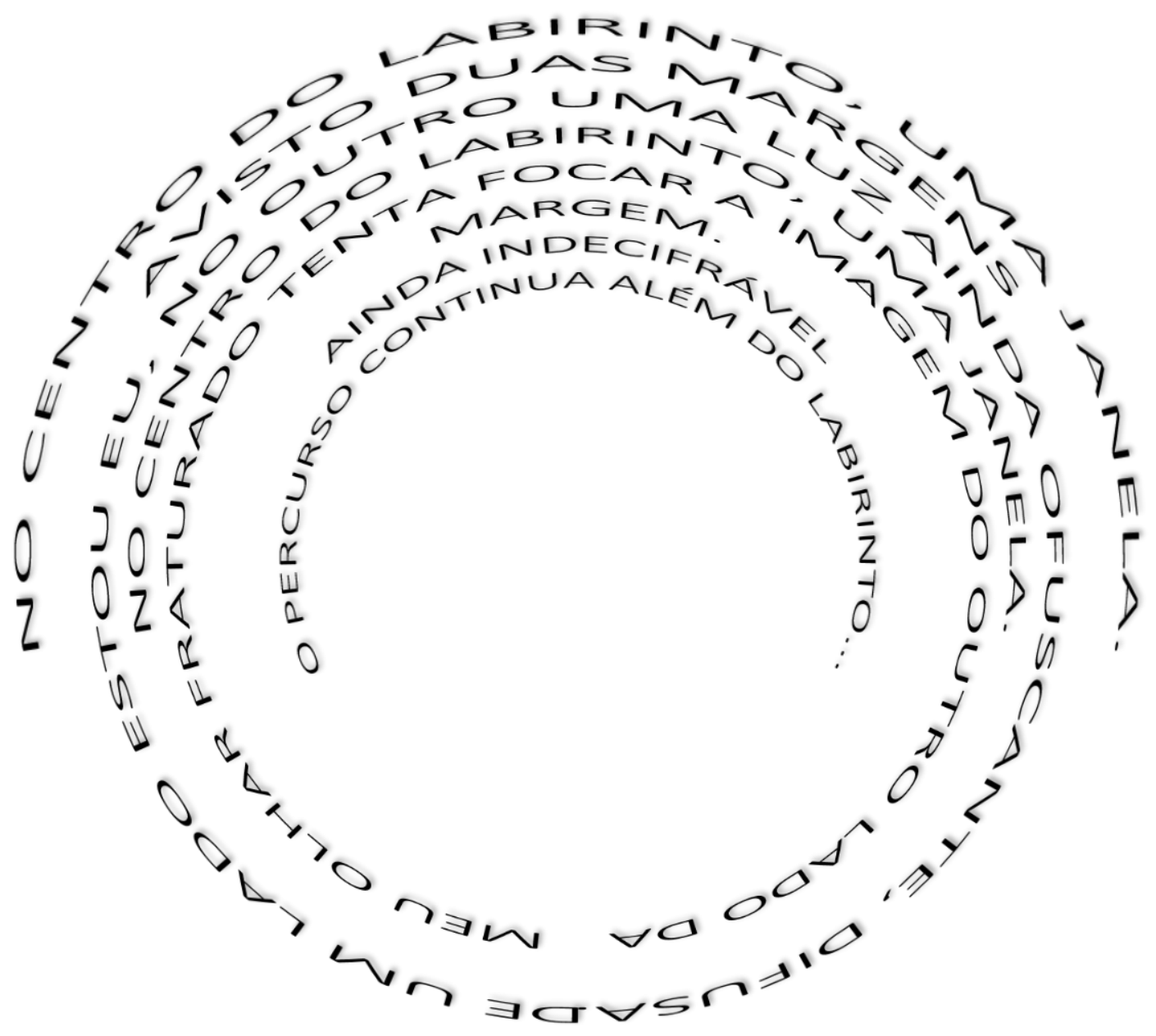

318 


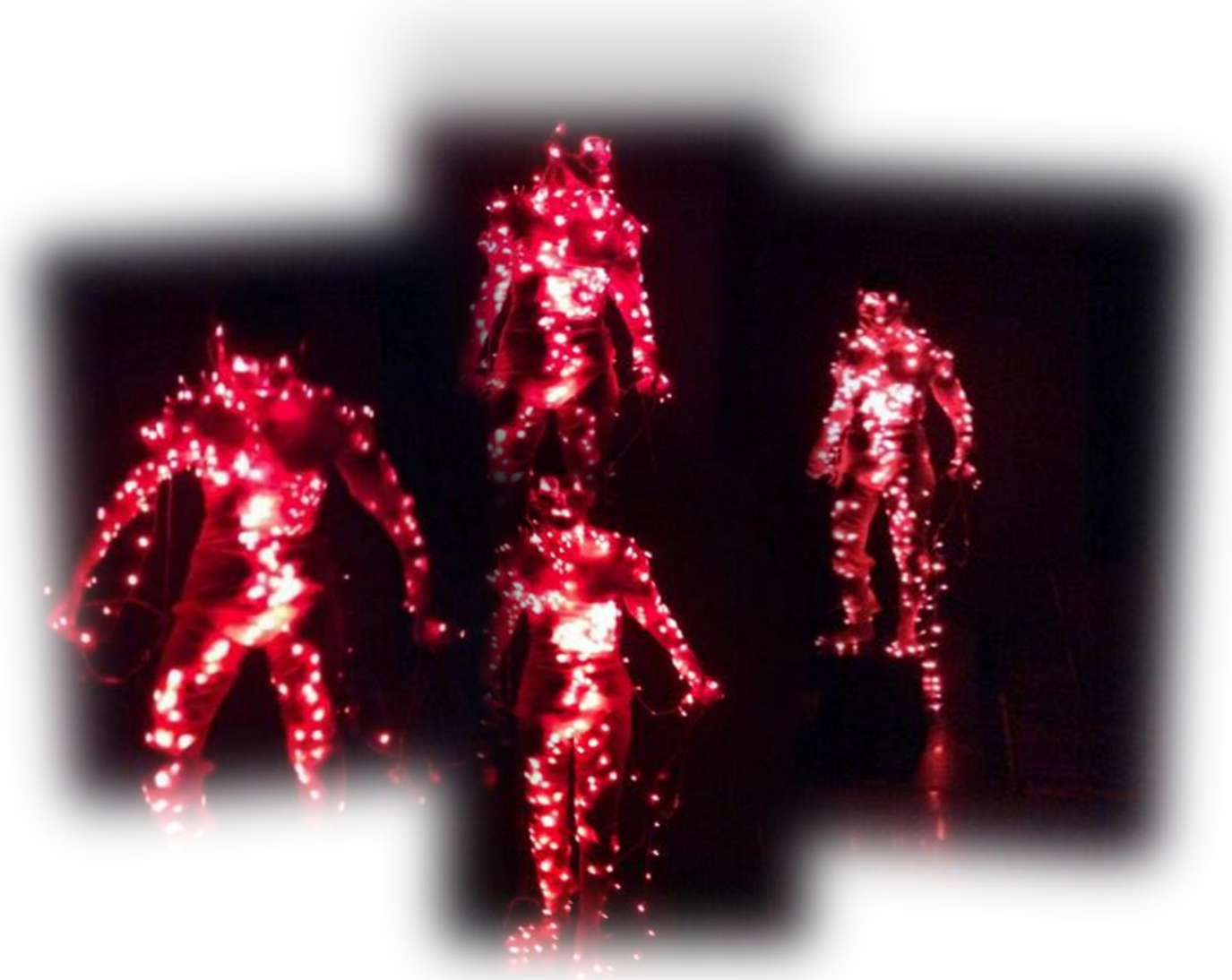

Fonte: Cláudia de Bem (performer) 
Chega o momento em que, ao examinar e refletir sobre estas experiências, encontro pontos de convergência nos escritos de Richard Schechner sobre o teatro ambiental, em que se aspira recuperar o espírito das cerimônias rituais nas comunidades primitivas xamânicas com o intuito de traçar paralelos sintomáticos e pontos de contato com o teatro e, especialmente, com o trabalho do ator-performer. Creio que em Hierofanias, os espaços construídos tinham este sentido visceral, a comunicação do espaço interior do corpo e do interior do espaço, ativando todos os recursos perceptivos com os quais descobrimos que alguns conceitos, aparentemente místicos, têm suas raízes na realidade de outros povos e cultos na singularidade de cada performer. Apesar de não nos determos a analisar a origem destes repertórios místicos, perseguimos a relação viva entre os espaços internos do corpo e dos espaços através dos quais se move o corpo e com os quais nos comunicamos. Também a identificação com uma arte fenomenológica, na experimentação direta com a luz-fenômeno através do fogo, resultando numa conscientização das minhas ações artísticas com uma arte perceptiva e ambiental. Criar na natureza e com ela, nessa potência receptiva do corpo em existir nestes lugares que acolhem outras conexões de existência. 
Com este vasto repertório de olhares, linguagens, imagens, outro percurso desafiante é recontar estas histórias de luz.

Me sirvo de uma mediação tecnológica, a arte-mídia para operar experiências transversalmente. Tomar posse destas tecnologias para dar um novo arranjo neste duplo espaço: o real e o virtual. Isto implica em ampliar a ação artística do campo da percepção para o da recepção. Um salto do analógico para o digital. O diálogo criativo se estabelece com outra interface: o vídeo.

$\mathrm{O}$ ato de criar com meios tecnológicos exige novos paradigmas e posturas diante do fazer. Uma assimilação das potencialidades e qualidades que a tecnologia oferece para que você possa utilizá-las como ferramenta criativa. Isto inclui a escolha de programas digitais adequados, que sejam aliados aos desejos criativos.

Para contextualizar o processo criativo, recorro a conceitos e pensamentos sobre

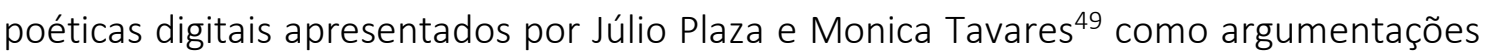
para a compreensão e identificação das etapas deste processo criativo.

Primeiramente, identifiquei as operações com o método Mito Poético característico do fenômeno de bricolagem que, segundo Lévi Strauss, significa "trabalho usando meios expedientes que denunciam a ausência de um plano preconcebido e se afastam dos processos e normas adotadas pela técnica" ${ }^{50}$. A característica é elaborar

\footnotetext{
49 TAVARES; PLAZA, 1988

50 apud TAVARES: PLAZA, 1988, p.112
} 
conjuntos estruturados utilizando resíduos e fragmentos dos acontecimentos sem perda do significado. A construção de imagens híbridas se enquadra neste pensamento, elas são criadas a partir do repertório contido nas práticas e se reorganizam sem prejudicar o sentido e as reflexões do todo. Recodificação. Portanto, a obra seria criada com o material videográfico que documentava as experiências na íntegra. Esta foi a base estrutural para o processo de criação.

Escolhi o programa de edição Première como aliado nesta ação. A postura diante de um companheiro tecnológico requer informações sobre ele, suas habilidades, competências, para que se estabeleça uma comunicação criativa e potente entre nós. Era fundamental o entendimento da ferramenta tecnológica para buscar conexões desta relação. Não existia a possibilidade de ter um técnico para fazer o processo de decupagem, que no cinema é feito por profissionais especializados na técnica. Por se tratar de uma obra de recodificação de práticas artísticas vividas e captadas por mim, as memórias das experiências e o pensamento sensível sobre elas representavam a matéria poética de interação com a máquina. Precisava existir uma fluidez entre o acontecimento e a hibridização feita no programa.

O espaço virtual oferece um campo de infinitas possibilidades e uma liberdade de inventar e produzir. Os limites se encontram justamente nesta interatividade de inteligências. No limiar destas relações e com o reconhecimento das minhas limitações, iniciei o percurso. O foco estava em manter o fogo aceso. 
Este tipo de prática favorece um trabalho de equipe que, segundo Simondon ${ }^{51}$, inclui um criador apenas como indivíduo singular que tenta vencer os limites e objetividade da máquina no sentido de resgatá-los como elementos formativos do seu fazer. O autor denomina esta relação de "isodinamismo", disposta no cruzamento do funcionamento físico da máquina.

Aqui, o saber passa a ser fundamental para o resultado, e o programa é um elemento determinante, agenciador e instaurador de possibilidades de criação. O pacto se estabelece entre a minha subjetividade e o programa.

Ao estabelecer estas correspondências com o programa de edição, passei a organizar as ideias junto com ele. As operações se definiam de acordo com o produto, a obra, uma vídeo-performance que abrigasse todas as experiências. A ação artística estava em imaginar, criar e representar uma nova materialidade impregnada das experiências vividas.

Pensar arte com tecnologia significa outro laboratório experimental, outra ação. Construir essa narrativa virtual foi uma experiência significativa para a fruição dos sentidos e a percepção em outro ambiente. O mundo virtual é um ambiente de imersão, e ao acessá-lo mergulhamos noutra relação espaço-temporal. Apesar de os desdobramentos virtuais se mesclarem com a realidade das experiências, a tecnologia funciona como mediadora destas relações. No processo de decupagem, ao filtrar

\footnotetext{
${ }^{51}$ SIMONDON, 1969 apud PLAZA; TAVARES, 1988, p.64
} 
imagens e registros captados, vivi outras experiências interativas com as experiências. As imagens das tantas chamas e o corpo que avistamos são atualizadas e recodificadas virtualmente, dando lugar a formas ainda não vistas.

Esta imersão requer um olhar solitário para experimentar o duplo tempo-espaço, uma mudança de percepção das práticas e uma nova intensidade ao processo. É uma interlocução constante entre as possibilidades da máquina e do processo intuitivo do criador. Retorno à magia como um acesso a outra realidade. O conteúdo é uma poção com muitos ingredientes: amargos, doces, picantes e adstringentes remexidos num grande caldeirão tecnológico. Os desdobramentos virtuais são para mim isto, uma outra materialização gerada da alquimia do real e virtual, uma transmutação das imagens que se metamorfoseiam numa chama virtual viva.

A interatividade entre arte e tecnologia funciona como uma comunicação entre a materialidade da experiência e um outro olhar sobre ela, uma reflexão virtual onde pude experimentar outras possibilidades de operar e ampliar capacidades cognitivas de criação de imagens sensíveis que trazem outros significados às práticas vividas. O processo criativo do olhar se dá na relação entre a inteligência do programa dada pelos recursos de edição com os efeitos, movimentos, tempo e cortes, e também pelos caminhos singulares da subjetividade. O pensamento criador, assim, transforma-se com a relação simbiótica de dois processos cognitivos: o intuitivo e o racional. Este criar na máquina foi 
como recontar as histórias numa outra relação de espaço e tempo dada pelo espaço virtual, reviver as práticas e encontrar novos sentidos para minhas reflexões.

A vídeo-performance consiste numa fábula imagética e sonora destas histórias que vão sendo costuradas em encontros, antes invisíveis e agora possíveis. Com tais argumentos, tento recortar fragmentos das experiências de cada performer e ressignificar num fluxo de imagens que se deslocam, dando corporeidade a uma única performance.

A sonoridade foi criada e editada pela artista Carina Donida num diálogo permanente entre nós duas e as imagens. Desta forma, fomos desenhando o som. A intenção era dar uma sonoridade contida à vídeo-performance, e não criar uma trilha sonora. A matéria prima do som foi retirada de captações de áudio, colhidas nas práticas e reinventadas em estúdio através de programas de áudio.

Em junho de 2019, a vídeo-performance Hierofanias, que pode ser acessada pelo código abaixo, fez parte da Mostra de Países da Quadrienal de Praga ${ }^{52}$ como trabalho artístico em vídeo-performance de luz.

Figura 10-QR-Code-Hierofanias

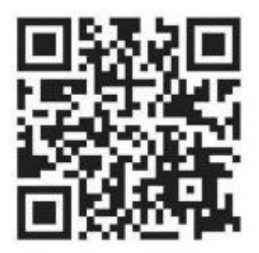

${ }^{52}$ Quadrienal de Praga Brasil - edição 2019. Disponível em <https://pqbrasil.org/pq19> Acesso JUL2020 


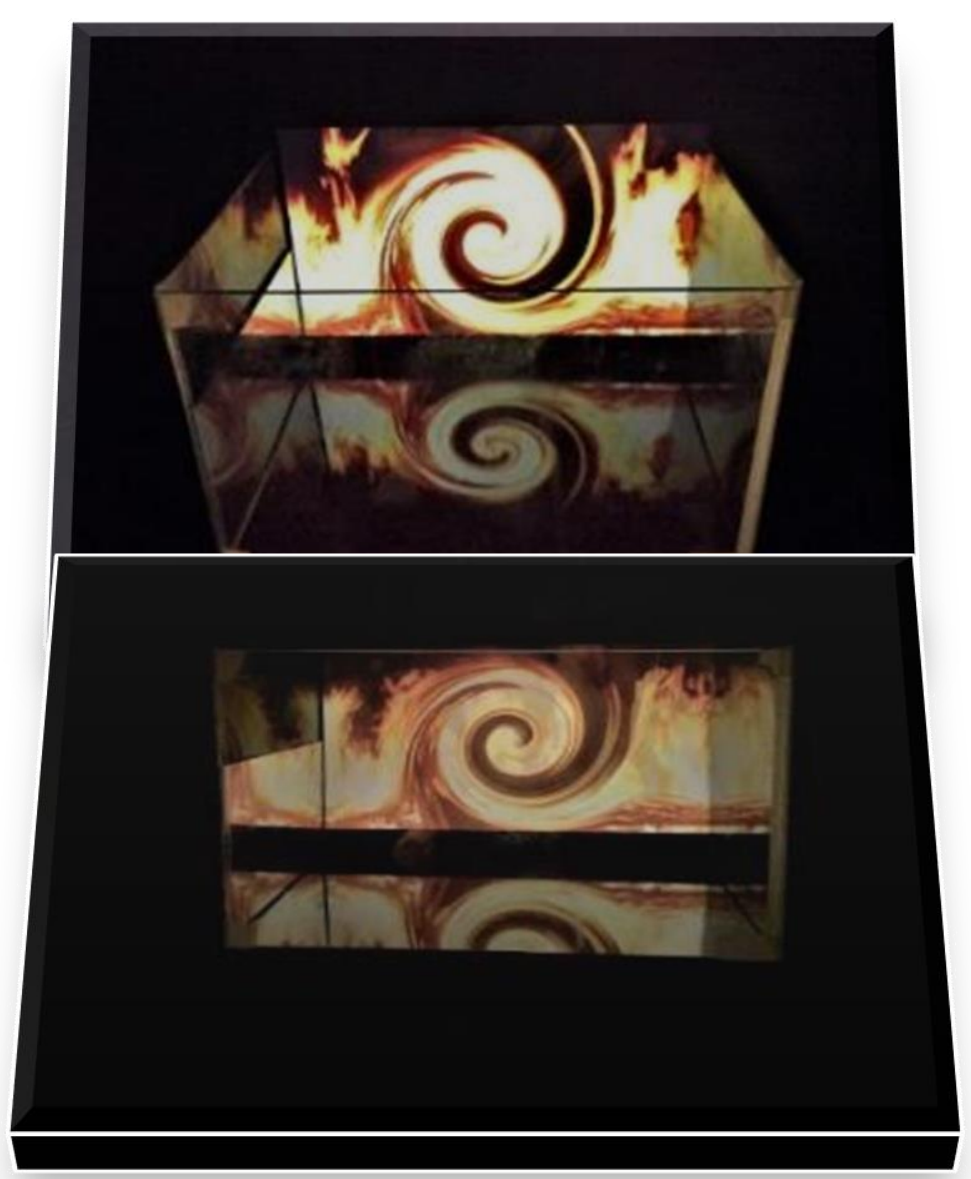

326 
Algo começa a fazer sentido neste momento tão intenso e frágil, quando somos todos convidados a refletir sobre o mundo que criamos. Eu, neste duplo exílio, finalizando a escrita; lá fora, uma peste que nos divide de nós mesmos e um mundo em combustão. Quase impossível não reavaliar o significado de tudo. A impermanência, a impotência e a fragilidade a que estamos submetidos reverberam dentro de cada um. Como anunciavam alguns profetas: são indícios da Era de Aquário, o isolamento a serviço do coletivo. Creio que nos chega de fato uma mudança já tão necessária à civilização. Talvez daqui a algumas décadas venhamos a chamar estes tempos de algum outro "ismo".

A arte para mim sempre teve uma relação com o belo, desejava ver e mostrar um mundo mais bonito, e o teatro me possibilitava construir mundos possíveis, equilibrados e com poucos riscos. Através da luz, encontrei uma expressão de interferência na visualidade de narrativas contadas por corpos e outras linguagens que dão vida ao espetáculo, e neste lugar sobrevivi. Nunca me dediquei a uma arte mais ativista e de denúncia, isto fiz como cidadã. A arte começou a tomar outra parte de mim - a necessidade de estabelecer uma conexão com a natureza me exigindo atitude de comprometimento em instaurar uma mudança de comportamento em relação ao meio ambiente. Com o tempo, isto veio a fluir nas minhas pesquisas e encontrei frestas para 
agir naquilo em que acredito, uma conectividade do ser, fazer e estar no mundo numa abordagem ecológica e social.

A minha prática artística tem caminhado neste sentido, numa busca de entendimento sobre a luz, como uma comunicação entre arte, corpo e natureza. No início deste deslocamento, isto não era tão consciente, talvez mais intuitivo. Reflito neste momento em que estamos reféns dos nossos próprios atos, a potência que reverbera dentro de mim. Todos estes anos em que venho pesquisando sobre as relações luzpercepção através de observações e práticas na natureza, agora encontram voz na minha escolha, minha arte e o mundo que desejo ver. Hoje, na minha residência em São Paulo, no duplo exílio, me comovo em pensar no quanto a natureza agradece pela distância dos seres humanos. Os animais, a floresta, o ar, os mares e rios se recuperam de nós. Toda dimensão da luz refeita nestas práticas artísticas junto a outros corpos, que puderam experimentar ao redor do fogo esta força e sabedoria cósmica, me inspiram a prosseguir com novas investigações.

Na trajetória da pesquisa científico-artística, encontramos vozes que alimentam nossas reflexões, mas creio que o mais potente e latente que me dispus a dividir foi a própria ação, as vivências intensas durante nossos trajetos pelas bifurcações deste labirinto de luz onde compartilhamos e olhamos a luz como um complemento de nós mesmos. Momentos em que permitimos uma outra dimensão para o nosso corpo, em que sentimos nossa existência como parte de algo maior, capaz de mudar nossa 
consciência sobre os espaços que criamos e compartilhamos. Revejo o quanto deixei de expor a minha espinha dorsal, aquilo que me motiva, que me leva ao gesto artístico. Começo a compreender minha identificação desde cedo com o teatro nas vozes de Craig, Appia, Antonin Artaud e Samuel Beckett pelo existencialismo e a metafísica que me habitam. Desta comunicação entre luz, natureza e teatro me dispus a rastrear os vestígios da luz deixados no meu corpo e na minha memória, e incorporo na construção de uma poética, numa perspectiva de traçar uma filosofia para a luz num ponto de vista constitutivo de uma arte de sentidos, ideias e invenção do mundo. Abrir para o campo da recepção e interatividade e repensar nossos espaços, incorporando relações mais orgânicas de forma a humanizá-los.

A consciência do transbordamento da luz é ilimitada, e examiná-la nesta dimensão infinita me direciona a uma arte mais engajada com o ambiente, capaz de transformar o pensamento em ação. Talvez este tenha sido o propósito para conhecer profundamente a luz e recuperar sua cosmogonia. A experiência com a luz é a concretização da representação que temos do mundo. Quando nos tornamos sensíveis a presença da luz, libertamos nossas imagens e aprendemos a olhar.

A luz me traz perguntas e poucas respostas, mas me contento em olhar para ela como um meio onde as imagens residem. 
Na tentativa de transcrever um pensamento, não elaborar um conceito, apenas palavras simples que contemplem o conhecimento sensível adquirido pelas experiências e por aquelas que já revivem nos meus repertórios íntimos, hoje eu diria:

Luz, para mim, é

Uma radiação sensivel e intuitiva vinda da estrela maior que, na sua composição mais pura de ondas e partículas, se desloca num feixe de fótons e nos revela o mundo, afeta nossos sentidos, consola em símbolos nossas crenças, acende imagens dentro de nós, e sua presença e ausência constituem nossos espaços internos e externos, nos contentando com prazer estético por sua beleza e magnitude.

Vejo-a assim como uma atriz completa e plena que percorre o espaço e o preenche com seu movimento e destreza, dando voz e imagem ao deleite de outros corpos e matérias, numa convivência mútua e necessária. 


\section{BIBLIOGRAFIA}

AGAMBEN, Giorgio. Profanações. Trad. Selvino J. Assmann. São Paulo: Boitempo, 2007.

ALLOA, Emmanuel (org). Pensar a Imagem. Filosófica. Trad. Carla Rodrigues, Fernando Fragozo, Alice Serra, Marianna Poyares. 1.ed, 2.reimpr. Belo Horizonte: Autêntica, 2017

APPIA, Adolphe. A Obra de Arte Viva. Lisboa: Arcádia, 1921.

ARNHEIM, Rudolf. Arte e Percepção Visual: uma psicologia da visão criadora. 12.ed. São Paulo: Pioneira, 1998.

ARTAUD, Antonin. O Teatro e seu Duplo. Trad. e posfácio Teixeira Coelho. São Paulo: Max Limonad, 1984.

AVENS, Robert. Imaginação e Realidade. Rio de Janeiro: Vozes, 1993.

BACHELARD, Gaston. A Chama de uma Vela. Trad. Glória de Carvalho Lins. Rio de Janeiro: Bertrand Brasil, 1989.

A Psicanálise do Fogo. Trad. Paulo Neves. São Paulo: Martins Fontes, 1999.

BAROJA, Júlio Caro. As Bruxas e seu Mundo. Janus. Trad. Joaquim S.Pereira. Lisboa: Vega, 1978.

BARROS, Anna. A Arte e a Percepção: um namoro entre a luz e o espaço. São Paulo: Annablume/ Fapesp, 1999.

BARTHES, Roland. A Câmara Clara. Trad. Júlio Castañon Guimarães. Rio de Janeiro: Nova Fronteira, 1984

BELTING, Hans. Likeness and Presence: a history of the image before the era of art. Chicago: University of Chicago, 1994 
BEN, Cláudia Pinto. A luz o iluminador e o performer: uma experiência perceptiva. Dissertação (Mestrado) Artes Cênicas - Universidade Federal do Rio Grande do Sul - UFRGS, Porto Alegre, 2014. Disponível em: <http://www.lume.ufrgs.br/handle/10183/105096>.

BENJAMIN, Walter. A Obra de Arte na Era de sua Reprodutibilidade Técnica. Obras Escolhidas: magia e técnica, arte e política. 6.ed. São Paulo: Brasiliense, 1994.

BERGSON. Henri. Matéria e Memória. São Paulo: Martins Fontes, 1999. Introdução à Metafísica. In. Cartas, Conferências e outros Escritos. São Paulo: Nova Cultural, 2005, p.21.

BOLEN, Jean Shinoda. A Sincronicidade e o Tao. São Paulo: Cultrix, 1979.

BORGES, Jorge Luis. Elogio da sombra. Trad. Carlos Nejar e Alfredo Jacques; rev.trad. Maria Carolina de Araujo e Jorge Schwartz. 2.ed. São Paulo: Globo, 2001.

BROOK, Peter. La Puerta Abierta: reflexiones sobre la interpretación y el teatro. Barcelona: Alba, 1998.

CABALLERO, Ilean Diéguez. Cenários Liminares. teatralidades, performances y política. Trad. Luis Alberto Alonso e Angela Reis. Uberlândia: UFU, 2011

CAPRA, Fritjof. As Conexões Ocultas: ciência para uma vida sustentável. São Paulo: Cultrix, 2002.

CHAUI, Marilena. Convite à Filosofia. São Paulo: Ática, 2000.

CHEVALIER, Jean; GHEERBRANT, Alain. Dicionário dos Símbolos. 26.ed. R.de Janeiro: J.Olympio, 2012.

COCCIA, Emanuelle. A Vida Sensível. Trad. Diego Cervelin. Florianópolis: Cultura e Barbárie, 2009.

COELHO, Teixeira. Antonin Artaud. 2.ed. São Paulo: Brasiliense, 1983 
CRAIG, Edward Gordon. Da Arte do Teatro. Lisboa: Arcádia, 1963.

. El Espacio como Espectáculo. Madrid: La Casa Encendida, 2009.

DAMÁSIO, Antonio. O Livro da Consciência: a construção do cérebro consciente. Lisboa: Círculo Leitores, 2010.

DIDI-HUBERMAN, Georges. O que vemos, o que nos olha. Trad. Paulo Neves. São Paulo: 34, 2010. . Sobrevivência dos Vagalumes. Trad. Vera Casa Nova. Belo Horizonte: UFMG, 2011. Diante da Imagem. Trad. Paulo Neves. São Paulo: 34, 2013.

DURAND, Gilbert. A imaginação simbólica. Lisboa: Arcádia, 1979.

ECO, Umberto. Sobre os espelhos e outros ensaios. Trad. Beatriz Borges. Rio de Janeiro: Nova Fronteira, 1989.

EDINGER, Edward F. Anatomia da Psique: o simbolismo alquímico na psicoterapia. São Paulo: Cultrix, 1985.

ELIADE, Mircea. El Chamanismo y las Técnicas Arcaicas del Éxtasis. México: Fonde de Cultura Economica, 1962.

. O Sagrado e o Profano. Trad. Rogério Fernandes. São Paulo: Martins Fontes, 1992.

ELIASSON, Olafur. Leer es Respirar, es Devenir. Barcelona: Gustavo Gili, 2012.

ERNST, Bruno. O Espelho Mágico de M. C. Escher. Trad. Maria Gonçalves Koller. Amsterdam: Taschen, 1991 
FEYNMANN, Richard P. A estranha teoria da luz e da matéria. Trad. Alexandre Barbosa. São Paulo: SENAI, 2008.

GAZZANIGA, Michael S.; HEATHERTON, Todd F. Ciência Psicológica: mente, cérebro e comportamento. Porto Alegre: Artmed, 2005.

GENNEP, Arnold Van. Os Ritos de Passagem. Trad. Mariano Ferreira. Rio de Janeiro: Vozes, 1978.

GONÇALVES. Márcia Cristina Ferreira. Filosofia da Natureza. Rio de Janeiro: Jorge Zahar, 2006

HUTIN, Serge. A Tradição Alquímica: a pedra filosofal e o elixir da longa vida. São Paulo:

Pensamento, 1979.

KIRK, G. S.; RAVEN, J. E. Os Filósofos Pré-Socráticos. Trad. Carlos Alberto L.Fonseca, Beatriz R.Barbosa e Maria Adelaide Pegado. 2.ed. Lisboa: Fundação Calouste Gulbenkian, 1966.

LEVY, Pierre. As Tecnologias da Inteligência: o futuro do pensamento na era da informática. São Paulo: 34, 1996.

O que é o Virtual? 2.ed. São Paulo: 34, 2011.

LIGIÉRO, Zeca (org.). Performance e Antropologia de Richard Schechner. R.de Janeiro: Mauad, 2012

LOPES, Elisabeth Silva. A performance da memória. Sala Preta (USP), v. 9, p. 135-145, 2010.

MERLEAU-PONTY, Maurice. O Visível e o Invisível. Trad. José Artur Gianotti e Armando Mora d'Oliveira. 3.ed. São Paulo: Perspectiva, 1992.

A Fenomenologia da Percepção. Trad. Carlos Alberto Ribeiro de Moura. São Paulo: Martins Fontes, 2011.

PEDROSA, Israel. Da Cor à Cor Inexistente. 10.ed. Rio de Janeiro: Senac Nacional, 2009. 
PESSOA, Fernando Pessoa. Antologia Poética. Barcelona: RBA, 1996

ROSA, João Guimarães. O Espelho. In: Primeiras Estórias. Rio de Janeiro: José Olympio, 1972, p.72

SAM, Jamie. Cartas do Caminho Sagrado. São Paulo: Rocco, 1990

SANTAELLA, Lucia. A percep̧̧ão: uma teoria semiótica. 2. ed. São Paulo: Experimento, 1998.

. Matrizes da linguagem e pensamento: sonora, visual, verbal. São Paulo: Iluminuras/

Fapesp, 2001.

SANTOS, Rodrigo Gonçalves dos. Perceber o (In) visível: o corpo desenhando uma trajetória existencial no espaço e no objeto. Tese (Doutorado) Programa de Pós-graduação em Educação, Universidade Federal de Santa Catarina, Florianópolis, 2011

SCHECHNER, Richard. "Restoration of behavior" between theater and anthropology.

Philadelphia: University of Pennsylvania Press, 1985, pp.35 - 166.

El Teatro Ambientalista. México: Árbol, 1988.

Performance Studies: an introduction. Nova lorque: Routledge, 2006.

SILVA, Franklin Leopoldo (sel.textos e trad.). Henri Bergson. Os Pensadores. São Paulo: Nova Cultural, 1989.

SONTAG, Susan. Ensaios sobre a Fotografia. 2.ed. Trad.Joaquim Paiva. Rio de Janeiro: Arbor, 1981.

SPINELLI, Miguel. A Noção de Arché no Contexto da Filosofia dos Pré-Socráticos. Hypnos, n.8, 2002. Disponível em: <http://www.hypnos.org.br/revista/index.php/hypnos/article/view/124/126> Acesso em ABR2020 
TAVARES, Monica; PLAZA, Julio. Processos Criativos com os Meios Eletrônicos. Poéticas Digitais. São Paulo: Hucitec, 1988

TAYLOR, Diana. O arquivo e o repertório: performance e memória cultural nas Américas. Belo Horizonte: UFMG, 2013.

TIBURI, Marcia. Olho de Vidro: a televisão e o estado de exceção da imagem. Rio de Janeiro: Record, 2011.

Aprender a pensar é descobrir o olhar. Jornal do MARGS, ed.103, set/out, 2013

TIEPPO, Carla. Uma Viagem pelo Cérebro: via rápida para entender Neurociência. São Paulo: Conectomus, 2019.

TUDELLA, Eduardo. A Luz na Gênese do Espetáculo. Salvador: EDUFBA, 2017.

TURNER, Vitor. O Processo Ritual Estrutura e Anti Estrutura. São Paulo: Vozes, 1974.

WERTHEIMER, Michael. Pequena História da Psicologia. Trad. Lólio Lourenço de Oliveira. São Paulo: Nacional, 1977.

WHITMONT, Edward C. A Busca do Símbolo: conceitos básicos de psicologia analítica. São Paulo: Cultrix, 1969.

ZAMBONI, Sílvio. A pesquisa em Arte: um paralelo entre arte e ciência. 2.ed. Campinas, SP: Autores Associados, 2001. 